\begin{abstract}
UNIVERSIDADE DE SÃO PAULO
FACULDADE DE FILOSOFIA, LETRAS E CIÊNCIAS HUMANAS

DEPARTAMENTO DE GEOGRAFIA

PROGRAMA DE PÓS-GRADUAÇÃO EM GEOGRAFIA HUMANA
\end{abstract}

ESPACIALIZAÇÃO DOS ACIDENTES DE TRÂNSITO EM UBERLÂNDIA (MG): TÉCNICAS DE GEOPROCESSAMENTO COMO INSTRUMENTO DE ANÁLISE - 2000 A 2004

Andréa Ríspoli Bernardino 
UNIVERSIDADE DE SÃO PAULO

FACULDADE DE FILOSOFIA, LETRAS E CIÊNCIAS HUMANAS

DEPARTAMENTO DE GEOGRAFIA

PROGRAMA DE PÓS-GRADUAÇÃO EM GEOGRAFIA HUMANA

\section{ESPACIALIZAÇÃO DOS ACIDENTES DE TRÂNSITO EM UBERLÂNDIA (MG): TÉCNICAS DE GEOPROCESSAMENTO COMO INSTRUMENTO DE ANÁLISE - 2000 A 2004}

Andréa Ríspoli Bernardino

Tese apresentada ao Programa de Pós Graduação em Geografia Humana, do Departamento de Geografia da Faculdade de Filosofia, Letras e Ciências Humanas da Universidade de São Paulo, para obtenção do título de Doutor em Geografia.

Área de Concentração: Geografia Humana

Orientadora: Prof ${ }^{a}$. Dr ${ }^{a}$. Claudette B. Junqueira 


\section{ANDRÉA RÍSPOLI BERNARDINO}

ESPACIALIZAÇÃO DOS ACIDENTES DE TRÂNSITO EM UBERLÂNDIA (MG): TÉCNICAS DE GEOPROCESSAMENTO COMO INSTRUMENTO DE ANÁLISE 2000 A 2004

Tese apresentada ao Programa de Pós Graduação em Geografia Humana do Departamento de Geografia da Faculdade de Filosofia, Letras e Ciências Humanas da Universidade de São Paulo para obtenção do título de Doutor em Geografia

Área de Concentração: Geografia Humana

Orientadora: Profa. Dra. Claudette B. Junqueira

São Paulo, de de 2007

Banca Examinadora

Profa. Dra. Claudette Barriguela Junqueira - USP (Orientadora) 
Aos meus pais, Nelson e Maria Amélia, que por eles passam a minha formação pessoal 


\section{AGRADECIMENTOS}

Agradeço imensamente à Professora Claudette, que desde o primeiro encontro não mediu esforços em compartilhar seus conhecimentos e experiências acadêmico-científicas, como orientadora, neste período. Sou muito grata, também, à confiança que depositou no meu trabalho;

É incomum a minha gratidão para com a Professora Denise, que desde a minha tendência nos caminhos da geografia urbana, em especial aos temas de trânsito e transporte, sempre me incentivou e esteve disposta a quaisquer discussões que tangiam para a temática do planejamento urbano;

À SETTRAN, por disponibilizar os dados, e, aos seus servidores e colegas que fiz há muito, sempre me auxiliaram com presteza;

À VERTRAN, que composta por uma equipe seletiva, sem distinção, apoiou-me em várias ocasiões relativas à coleta e à tabulação dos dados, obrigada a todos;

Agradeço em especial ao José Marcos, Gustavo Eugênio, Cecília, Lívia, Thiago Marra, que me apoiaram diretamente nas questões relacionadas ao banco de dados, assim como na configuração e formatação das figuras que ilustram este trabalho;

À Ana, secretária da pós-graduação da geografia na FFLCH/USP, agradeço a atenção quanto aos procedimentos burocráticos pertinentes ao departamento;

A todos os colegas do CNPq, e, Simone, Sandra, Gisele, Elza, Ricardo, Andréa Dias, Araújo e Angela que incentivaram à conclusão desta de uma ou outra forma, o meu agradecimento; 
Aos meus amigos, que perto ou longe, estimularam o encerramento desta etapa por mim percorrida, em especial a Rosana, Claudiane, Sueli, Di, Fernando, William, Carlos Póvoa, Rejane, Sérgio Elias, Marcinha, Deo, Antônio, Paula e Ariane;

A todos meus familiares que nas horas mais difíceis compreenderam o momento, em especial a minha mãe, o meu muito obrigado;

E, a todos que direta ou indiretamente contribuíram para a realização deste trabalho. 
"Quando existe avanço tecnológico sem avanço social, surge quase automaticamente, um aumento da miséria humana" 


\section{RESUMO}

Os números de ocorrências em acidentes de trânsito são assustadores. Avalia-se que o custo dos acidentes aproxime de 1\% do PIB em países pobres e $2 \%$ nas nações desenvolvidas. Em termos globais, são gastos U\$ 518 bilhões anuais. No Brasil, estudos apontam que houve uma queda de 20 mil vítimas fatais de acidentes de trânsito, de 1987 para 1998, apresentando, atualmente, em torno de 30 mil mortes/ano no trânsito. Essa redução pode ser em parte justificada pelo Código de Trânsito Brasileiro, que entrou em vigor em 22 de janeiro de 1998. Considerado como um desafio pelos órgãos gestores do planejamento urbano viário, a redução das ocorrências de acidentes de trânsito torna-se um tema discutido, incessantemente, na administração pública. Diante dessa leitura urbana, este estudo propõe conhecer as características dos acidentes de trânsito ocorridos na área urbana da cidade de Uberlândia entre os anos de 2000 e 2004, bem como espacializar as vias, os trechos e os cruzamentos com maior número de acidentes, com o intuito de identificá-los por meio de técnicas disponíveis em BRASIL (2002) e Gold (1998), que, adaptadas ao banco de dados disponíveis pela SETTRAN, determinaram quais são as vias, os trechos e os cruzamentos críticos. Por meio desses procedimentos, apresenta-se a identificação de vinte vias, vinte trechos e vinte cruzamentos que foram palco dos maiores números de acidentes ocorridos no trânsito e dos números mais altos de UPS dos acidentes de trânsito entre os anos de 2000 e 2004. Analisando a situação crítica dos segmentos analisados, as vias descritas a seguir foram consideradas importantes, por estarem enumeradas em todas as seleções hierarquizadas e agrupadas, bem como os trechos e os cruzamentos, sendo as Av. João Naves de Ávila e Av. Rondon Pacheco, seguidas da Av. Afonso Pena e Av. Floriano Peixoto. Para os trechos críticos, estas aparecem como sendo as vias principais e suas interseções mais significativas estão localizadas na área central e vias que dão acesso ao "shopping center". Quanto aos cruzamentos, as vias que fazem as interseções com as ora citadas possibilitam conflitos, que, pela alta freqüência dos acidentes de trânsito em um mesmo local, foram estabelecidos os pontos críticos pela significância que os números dos acidentes de trânsito apresentam e de suas especificações do local identificado. Para a redução das relações de conflitos no trânsito, bem como a prevenção de um grande número de ocorrências de acidentes de trânsito, devem ser consideradas medidas de educação que levem os cidadãos a atitudes e comportamentos de convivência ao utilizar o ambiente viário comum aos pedestres e veículos. Assim, o alcance deste objetivo é salutar, pois empenha-se na busca de estratégias que possam otimizar os recursos disponíveis e estabelecer parcerias que garantam a efetividade das estratégias definidas, afugentando esse mal que assola a cidade sem pedir licença.

Palavras-chave: acidentes de trânsito, espacialização de dados geográficos, pontos críticos, geoprocessamento, políticas públicas 


\section{ABSTRACT}

The numbers of traffic accidents occurrences are frightful. It is evaluated that the cost of the accidents is near to $1 \%$ of the GIP in poor countries and $2 \%$ in the developed nations. In global terms, U\$ 518 billion/year are expensed. In Brazil, studies point that there was a fall in 20 thousand of fatal victims in traffic accidents between 1987 and 1998. Currently, we had around 30 thousand deaths/year in the traffic. This reduction can be partly justified for the Brazilian Transit Code, which works since 22 January 1998. Considered a challenge for the managing agencies of the road urban planning, the reduction of the traffic accidents occurrences become a subject incessantly discussed in the public administration. In front of this urban reading, this study proposes to know the characteristics of the traffic accidents occurred in the urban area of the Uberlândia-MG, considering the period 2004-2004, as well to space the streets, the stretches and the crossings with more accidents, intending to identify this streets through techniques available in BRAZIL (2002) and Gold (1998). This procedure was adapted from the available data base by SETTRAN and they had determined which are the critical streets, stretches and crossings in question. By these procedures, we present the identification of twenty streets, twenty stretches and twenty crossings where happens the biggest numbers of transit accidents and the highest numbers of UPS of the traffic accidents between 2000 and 2004. Considering the critical situation of the analyzed segments, the following described streets had been considered important because they are enumerated in all of the ranked and grouped selections, as well as the stretches and the crossings. The streets are: João Naves de Ávila Avenue, Rondon Pacheco Avenue, followed by Afonso Pena Avenue and Floriano Peixoto Avenue. For the critical stretches, these are the main streets and its more significant intersections are located in the central area and streets with access to the "Shopping Center". About the crossings, the streets intersected with those streets make possible the conflicts. On account of the high frequency of the traffic accidents in a same local, we established the critical points with basis in the significance that the numbers of the traffic accidents present and specifications presented by the identified place. For the reduction of the conflict relations in traffic, as well for to prevent a great number of traffic accidents occurrences, we considered education measures that take the citizens to attitudes and behaviors of social living when they use a street common to the pedestrians and vehicles. Thus, the reach of this objective is special, once it is pledged in the search of strategies that can optimize the available resources and establish partnerships for guarantee the effectiveness of the defined strategies, driving away this mad which devastates the city.

Keywords: traffic accidents, geographic data spacialization, critical points, geoprocessing, public politics 


\section{LISTA DE FIGURAS}

Figura 1 - Fluxograma dos procedimentos no tratamento de pontos críticos 90

Figura 2 - Av. Rondon Pacheco. Via de trânsito rápido que absorve volume 209 intenso de veículos, Uberlândia, 2006

Figura 3 - Vista da Av. Afonso Pena trecho da área central, Uberlândia, 211 2006

Figura 4 - Vista parcial do trecho da Av. João Naves de Ávila entre Av. 214 Ubiratan Honório de Castro e R. Luiza de Jesus, Uberlândia, 2006

Figura 5 - Vista do trecho compreendido pelas via principal Av. Afonso 216 Pena e suas interseções, R. Duque de Caxias e R. Machado de Assis, Uberlândia, 2006

Figura 6 - Vista do trecho compreendido pela Av. João Naves de Ávila e 216 suas interseções, Av. Floriano Peixoto e Av. Cesário Alvim, Uberlândia, 2006

Figura 7 - Vista do cruzamento da Av. João Naves de Ávila com a Av. 221 Rondon Pacheco, Uberlândia, 2007

Figura 8 - Vista parcial da Av. Antônio Thomaz Ferreira de Rezende que faz 224 importante ligação para o setor de indústrias, Uberlândia, 2007

Figura 9 - Av. Antônio Thomaz Ferreira de Rezende com Av. Comendador

224 Alexandrino Garcia. Observação da largura do cruzamento, Uberlândia, 2007 Figura 10 - Cruzamento da Av. Rondon Pacheco com Av. Nicomedes Alves 239 dos Santos, Uberlândia, 2007

Figura 11 - Cruzamento Av. Araguari com R. Padre Pio, Uberlândia, 2007 239

Figura 12 - Estação de embarque e desembarque dos usuários do transporte 240 coletivo urbano, no Corredor Estrutural da Av. João Naves de Ávila, Uberlândia, 2007

Figura 13 - Manutenção na sinalização horizontal no cruzamento da Av. 241 Antônio Thomaz Ferreira de Rezende com a Av. Comendador Alexandrino Garcia, Uberlândia, 2007 


\section{LISTA DE GRÁFICOS}

Gráfico 1 - Número de acidentes por ano sobre o tipo de veículo envolvido, 100 2000 a 2004

Gráfico 2 - Número de acidentes considerando as condições presumíveis 104 da via, 2000 a 2004

Gráfico 3 - Número de acidentes considerando as características da via por 105 ano, 2000 a 2004

Gráfico 4 - Número de acidentes por severidade (danos materiais) 107 relacionados com as causas presumíveis, 2000 a 2003

Gráfico 5 - Número de acidentes por severidade (feridos leves) 107 relacionados com as causas presumíveis, 2000 a 2003

Gráfico 6 - Número de acidentes por severidade (feridos graves) 108 relacionados com as causas presumíveis, 2000 a 2003

Gráfico 7 - Número de acidentes por severidade (mortos) relacionados com 108 as causas presumíveis, 2000 a 2003

Gráfico 8 - Número de acidentes por severidade relacionados às causas 111 presumíveis, 2004

Gráfico 9 - Número de acidentes dos grupos de idade dos condutores 114 relacionados à severidade (danos materiais), 2000 a 2004

Gráfico 10 - Número de acidentes dos grupos de idade dos condutores 115 relacionados à severidade (feridos leves), 2000 a 2004

Gráfico 11 - Número de acidentes dos grupos de idade dos condutores 115 relacionados à severidade (feridos graves), 2000 a 2004

Gráfico 12 - Número de acidentes dos grupos de idade dos condutores 116 relacionados à severidade (mortos), 2000 a 2004

Gráfico 13 - Número de acidentes por grupos de idade dos condutores dos 117 veículos para o sexo masculino, 2000 a 2004 
Gráfico 14 - Número de acidentes por grupos de idade dos condutores dos 118 veículos para o sexo feminino, 2000 a 2004

Gráfico 15 - Número de acidentes por tempo de habilitação dos condutores 119 relacionados com a severidade (danos materiais), 2000 a 2004

Gráfico 16 - Número de acidentes por tempo de habilitação dos condutores 120 relacionados com a severidade (feridos leves), 2000 a 2004

Gráfico 17 - Número de acidentes por tempo de habilitação dos condutores 120 relacionados com a severidade (feridos graves), 2000 a 2004

Gráfico 18 - Número de acidentes por tempo de habilitação dos condutores 121 relacionados com a severidade (mortos), 2000 a 2004

Gráfico 19 - Número de acidentes por horários, 2000-2004

Gráfico 20 - Número de acidentes por horários quanto à severidade (danos 124 materiais), 2000 a 2004

Gráfico 21 - Número de acidentes por horários quanto à severidade (feridos 125 leves), 2000 a 2004

Gráfico 22 - Número de acidentes por horários quanto à severidade (feridos 125 graves), 2000 a 2004

Gráfico 23 - Número de acidentes por horários quanto à severidade 126 (mortos), 2000 a 2004

Gráfico 24 - Número de acidentes por mês para todos os dias da semana, 129 2000

Grafico 25 - Número de acidentes por mês para todos os dias da semana, 130 2001

Grafico 26 - Número de acidentes por mês para todos os dias da semana, 131 2002

Gráfico 27 - Número de acidentes por mês para todos os dias da semana, 132 2003 
Grafico 28 - Número de acidentes por mês para todos os dias da semana, 133 2004

Gráfico 29 - Número de acidentes por mês, 2000 a 2004 135

Gráfico 30 - Número de acidentes por ano, 2000 a 2004 136 


\section{LISTA DE MAPAS}

Mapa 1 - Localização do município de Uberlândia

Mapa 2 - Principais rodovias de acesso ao município de Uberlândia

Mapa 3 - Rodovias que interceptam a área urbana de Uberlândia

Mapa 4 - Sistema viário básico, Uberlândia, 1991

Mapa 5 - Parcelamento e zoneamento do uso e ocupação do solo, Uberlândia, 2000

Mapa 6 - Espacialização das vinte vias com maior número de acidentes de trânsito no ano de 2000, Uberlândia

Mapa 7 - Espacialização das vinte vias com maior número de acidentes de trânsito no ano de 2001, Uberlândia

Mapa 8 - Espacialização das vinte vias com maior número de acidentes de trânsito no ano de 2002, Uberlândia Mapa 9 - Espacialização das vinte vias com maior número de acidentes de trânsito no ano de 2003, Uberlândia

Mapa 10 - Espacialização das vinte vias com maior número de acidentes 151 de trânsito no ano de 2004, Uberlândia

Mapa 11 - Espacialização dos vinte trechos com maior número de 154 acidentes de trânsito no ano de 2000, Uberlândia

Mapa 12 - Espacialização dos vinte trechos com maior número de 156 acidentes de trânsito no ano de 2001, Uberlândia

Mapa 13 - Espacialização dos vinte trechos com maior número de 158 acidentes de trânsito no ano 2002, Uberlândia

Mapa 14 - Espacialização dos vinte trechos com maior número de 160 acidentes de trânsito no ano de 2003, Uberlândia 
Mapa 15 - Espacialização dos vinte trechos com maior número de 162 acidentes de trânsito no ano de 2004, Uberlândia

Mapa 16 - Espacialização dos vinte cruzamentos com maior número de 165 acidentes de trânsito no ano de 2000, Uberlândia

Mapa 17 - Espacialização dos vinte cruzamentos com maior número de 167 acidentes de trânsito no ano de 2001, Uberlândia

Mapa 18 - Espacialização dos vinte cruzamentos com maior número de 169 acidentes de trânsito no ano de 2002, Uberlândia

Mapa 19 - Espacialização dos vinte cruzamentos com maior número de 171 acidentes de trânsito no ano de 2003, Uberlândia

Mapa 20 - Espacialização dos vinte cruzamentos com maior número de 173 acidentes de trânsito no ano de 2004, Uberlândia

Mapa 21 - Espacialização das vinte vias com os números mais altos de 177 UPS dos acidentes de trânsito no ano de 2000, Uberlândia

Mapa 22 - Espacialização das vinte vias com os números mais altos de 179 UPS dos acidentes de trânsito no ano de 2001, Uberlândia

Mapa 23 - Espacialização das vinte vias com os números mais altos de 181 UPS dos acidentes de trânsito no ano de 2002, Uberlândia

Mapa 24 - Espacialização das vinte vias com os números mais altos de 183 UPS dos acidentes de trânsito no ano de 2003, Uberlândia

Mapa 25 - Espacialização das vinte vias com os números mais altos de 185 UPS dos acidentes de trânsito no ano de 2004, Uberlândia

Mapa 26 - Espacialização dos vinte trechos com os números mais altos de 188 UPS dos acidentes de trânsito no ano de 2000, Uberlândia

Mapa 27 - Espacialização dos vinte trechos com os números mais altos de 190 UPS dos acidentes de trânsito no ano de 2001, Uberlândia

Mapa 28 - Espacialização dos vinte trechos com os números mais altos de 192 UPS dos acidentes de trânsito no ano de 2002, Uberlândia 
Mapa 29 - Espacialização dos vinte trechos com os números mais altos de UPS dos acidentes de trânsito no ano de 2003, Uberlândia

Mapa 30 - Espacialização dos vinte trechos com os números mais altos de UPS dos acidentes de trânsito no ano de 2004, Uberlândia

Mapa 31 - Espacialização dos vinte cruzamentos com os números mais 199 altos de UPS dos acidentes de trânsito no ano de 2000, Uberlândia

Mapa 32 - Espacialização dos vinte cruzamentos com os números mais 201 altos de UPS dos acidentes de trânsito no ano de 2001, Uberlândia

Mapa 33 - Espacialização dos vinte cruzamentos com os números mais 203 altos de UPS dos acidentes de trânsito no ano de 2002, Uberlândia

Mapa 34 - Espacialização dos vinte cruzamentos com os números mais 205 altos de UPS dos acidentes de trânsito no ano de 2003, Uberlândia

Mapa 35 - Espacialização dos vinte cruzamentos com os números mais 207 altos de UPS dos acidentes de trânsito no ano de 2004, Uberlândia

Mapa 36 - Vias, trechos e cruzamentos críticos identificados no ano de 227 2004

Mapa 37 - Vias na área urbana de Uberlândia que possuem fiscalização 245 eletrônica (radar fixo) com seus limites de velocidade, 2004

Mapa 38 - Cruzamentos na área urbana de Uberlândia que possuem 246 fiscalização eletrônica (avanço de sinal) com seus limites de velocidade, 2004 


\section{LISTA DE QUADROS}

Quadro 1 - Contribuições para a tecnologia da informação espacial

Quadro 2 - Número de acidentes por ano em relação ao tipo de veículo 100 envolvido, 2000 a 2004

Quadro 3 - Número de acidentes considerando as condições presumíveis 104 da via, 2000 a 2004

Quadro 4 - Número de acidentes considerando as características da via, 106 2000 a 2004

Quadro 5 - Número de acidentes por severidades e suas causas, 2000 a 110 2003

Quadro 6 - Número de acidentes por severidades relacionados às causas 112 presumíveis, 2004

Quadro 7 - Número de acidentes dos grupos de idade dos condutores 116 relacionados com as severidades, 2000 a 2004

Quadro 8 - Número de acidentes por grupos de idade e sexo, 2000 a $2004 \quad 118$

Quadro 9 - Número de acidentes por tempo de habilitação dos condutores 122 relacionados com as severidades, 2000 a 2004

Quadro 10 - Número de acidentes por horários relacionados às 127 severidades, 2000 a 2004

Quadro 11 - Número de óbitos em acidentes de trânsito, 2000 a 2004 - 128 Uberlândia

Quadro 12 - Número de acidentes por mês para todos os dias da semana, 129 2000

Quadro 13 - Número de acidentes por mês para todos os dias da semana, 130 2001

Quadro 14 - Número de acidentes por mês para todos os dias da semana, 131 2002 
Quadro 15 - Número de acidentes por mês para todos os dias da semana, 132 2003

Quadro 16 - Número de acidentes por mês para todos os dias da semana, 133 2004

Quadro 17 - Número de acidentes por mês, 2000 a 2004

Quadro 18 - Número de acidentes por ano, 2000 a 2004

Quadro 19 - As vinte vias com maior número de ocorrências de acidentes

de trânsito, ano 2000, Uberlândia

Quadro 20 - As vinte vias com maior número de ocorrências de acidentes de trânsito, ano 2001, Uberlândia

Quadro 21 - As vinte vias com maior número de ocorrências de acidentes de trânsito, ano 2002, Uberlândia

Quadro 22 - As vinte vias com maior número de ocorrências de acidentes de trânsito, ano 2003, Uberlândia

Quadro 23 - As vinte vias com maior número de ocorrências de acidentes de trânsito, ano 2004, Uberlândia

Quadro 24 - Os vinte trechos com maior número de ocorrências de 153 acidentes de trânsito, ano 2000, Uberlândia

Quadro 25 - Os vinte trechos com maior número de ocorrências de 155 acidentes de trânsito, ano 2001, Uberlândia

Quadro 26 - Os vinte trechos com maior número de ocorrências de 157 acidentes de trânsito, ano 2002, Uberlândia

Quadro 27 - Os vinte trechos com maior número de ocorrências de 159 acidentes de trânsito, ano 2003, Uberlândia

Quadro 28 - Os vinte trechos com maior número de ocorrências de 161 acidentes de trânsito, ano 2004, Uberlândia

Quadro 29 - Os vinte cruzamentos com maior número de ocorrências de 164 acidentes de trânsito, ano 2000, Uberlândia 
Quadro 30 - Os vinte cruzamentos com maior número de ocorrências de 166 acidentes de trânsito, ano 2001, Uberlândia

Quadro 31 - Os vinte cruzamentos com maior número de ocorrências de 168 acidentes de trânsito, ano 2002, Uberlândia

Quadro 32 - Os vinte cruzamentos com maior número de ocorrências de 170 acidentes de trânsito, ano 2003, Uberlândia

Quadro 33 - Os vinte cruzamentos com maior número de ocorrências de 172 acidentes de trânsito, ano 2004, Uberlândia

Quadro 34 - As vinte vias com os números mais altos de UPS dos 176 acidentes de trânsito, ano 2000, Uberlândia

Quadro 35 - As vinte vias com os números mais altos de UPS dos 178 acidentes de trânsito, ano 2001, Uberlândia

Quadro 36 - As vinte vias com os números mais altos de UPS dos 180 acidentes de trânsito, ano de 2002, Uberlândia

Quadro 37 - As vinte vias com os números mais altos de UPS dos 182 acidentes de trânsito no ano de 2003, Uberlândia

Quadro 38 - As vinte vias com os números mais altos de UPS dos 184 acidentes de trânsito para o ano de 2004, Uberlândia

Quadro 39 - Os vinte trechos com os números mais altos de UPS dos 187 acidentes de trânsito no ano de 2000, Uberlândia

Quadro 40 - Os vinte trechos com os números mais altos de UPS dos 189 acidentes de trânsito no ano de 2001, Uberlândia

Quadro 41 - Os vinte trechos com os números mais altos de UPS dos 191 acidentes de trânsito no ano de 2002, Uberlândia Quadro 42 - Os vinte trechos com os números mais altos de UPS dos 193 acidentes de trânsito no ano de 2003, Uberlândia Quadro 43 - Os vinte trechos com os números mais altos de UPS dos 195 acidentes de trânsito no ano de 2004, Uberlândia Quadro 44 - Os vinte cruzamentos com os números mais altos de UPS dos 198 acidentes de trânsito no ano de 2000, Uberlândia 
Quadro 45 - Os vinte cruzamentos com os números mais altos de UPS dos 200 acidentes de trânsito no ano de 2001, Uberlândia Quadro 46 - Os vinte cruzamentos com os números mais altos de UPS dos 202 acidentes de trânsito no ano de 2002, Uberlândia Quadro 47 - Os vinte cruzamentos com os números mais altos de UPS dos 204 acidentes de trânsito no ano de 2003, Uberlândia Quadro 48 - Os vinte cruzamentos com os números mais altos de UPS dos 206 acidentes de trânsito no ano de 2004, Uberlândia Quadro 49 - Identificação das vias ou segmentos críticos por ano 212 Quadro 50 - Identificação dos trechos críticos por ano 217 Quadro 51 - Identificação dos cruzamentos ou pontos críticos por ano 222 Quadro 52 - Identificação das vias, dos trechos e dos cruzamentos críticos 226 para o ano de 2004

Quadro 53 - Projetos de geometria viária executados, 2001 a 2004 


\section{LISTA DE TABELAS}

Tabela 1 - População brasileira residente na área urbana e rural, 1970 a 8 2000

Tabela 2 - População regional brasileira por situação de domicílio, 2000

Tabela 3 - Mortes no trânsito em países selecionados $\quad 17$

Tabela 4 - Produção brasileira de veículos por tipo de combustível, $2000 \quad 18$

Tabela 5 - Mortes por acidentes de trânsito/10.000 veículos no Brasil, 199019 a 1999

Tabela 6 - Total da frota brasileira e habitantes/veículos, 1950 a junho de 20 2006

Tabela 7 - As dez cidades brasileiras com maior número de veículos 21 emplacados, 2005

Tabela 8 - Acidentes de trânsito no Brasil, 1961 a 2000

Tabela 9 - Número de vítimas de acidentes de trânsito, 1998 a 2002, Brasil 47

Tabela 10 - População residente em Uberlândia, 1950 a $1996 \quad 60$

Tabela 11 - Composição modal do tráfego, Uberlândia, 197062

Tabela 12 - Área $\left(\mathrm{Km}^{2}\right)$ do município de Uberlândia, 1991

Tabela 13 - Destinação dos imóveis urbanos, 1989

Tabela 14 - Evolução da frota total de veículos da cidade de Uberlândia - 69 2002 a junho de 2006 


\section{LISTA DE ABREVIATURAS E SIGLAS}

ANFAVEA - Associação Nacional dos Fabricantes de Veículos Automotores ANTP - Associação Nacional dos Transportes Públicos

ARCOM - Armazém do Comércio/S.A.

Art. - Artigo

BDI - Banco de Dados Integrados

B.O. - Boletim de Ocorrência

CET - Companhia de Engenharia de Tráfego

CETRAN - Conselho Estadual de Trânsito

cf. - conferir

CID - Código Internacional de Doenças

Cont. - continuação

CONTRAN - Conselho Nacional de Trânsito

CONTRANDIFE - Conselho de Trânsito do Distrito Federal

CTB - Código de Trânsito Brasileiro

DATASUS - Departamento de Informações do Sistema Único de Sáude

DENATRAN - Departamento Nacional de Trânsito

DNER - Departamento Nacional de Estradas e Rodagem

DOT - Departamento de Operações de Tráfego

EUA - Estados Unidos da América

GEIPOT - Empresa Brasileira de Planejamento de Transportes

GIS - Geographic Information System

GPS - Global Position System

Hab. - habitantes

IBGE - Instituto Brasileiro de Geografia e Estatística

IBOPE - Instituto Brasileiro de Opinião Pública e Estatística

IMESC - Instituto de Medicina Social e de Criminologia

IML - Instituto Médico Legal

IMPTCT - Informe Mundial sobre Prevenção dos Traumatismos Causados no Trânsito

IPEA - instituto de Pesquisas Econômicas Aplicadas

JARI - Junta Administrativa de Recursos de Infrações 
MGTV - Jornal local televisivo de Uberlândia

MMA - Ministério do Meio Ambiente

$\mathrm{N}^{\circ}$. - Número

NA - Não Apurado

OMS - Organização Mundial da Saúde

OPAS - Organização Pan-americana da Saúde

Org. - Organização

PDI - Processamento Digital de Imagens

PMU - Prefeitura Municipal de Uberlândia

PNT - Política Nacional de Trânsito

RENACH - Registro Nacional de Condutores Habilitados

R.O. - Registro de Ocorrência

SEADE - Fundação Sistema Estadual de Análise de Dados

SETTRAN - Secretaria Municipal de Trânsito e Transportes - Uberlândia

SIG - Sistema de Informação Geográfica

SIPAT - Semana Interna de Prevenção de Acidente

SIT - Sistema Integrado de Transporte

s/i - sem informação

SNT - Sistema Nacional de Trânsito

UFU - Universidade Federal de Uberlândia

UnB - Universidade de Brasília

UPS - Unidade Padrão de Severidade 


\section{SUMÁRIO}

Folha de rosto

i

Banca Examinadora

ii

Dedicatória

iii

Agradecimentos

iv

Epígrafe

vi

Resumo

vii

Abstract

viii

Lista de Figuras

ix

Lista de Gráficos

$x$

Lista de Mapas

xiii

Lista de Quadros

xvi

Lista de Tabelas

$\mathrm{XX}$

Lista de Abreviaturas e Siglas

$x x i$

INTRODUÇÃO

CAPÍTULO 1 - O PROCESSO DE URBANIZAÇAO, NORMAS E 7 CONFLITOS DIANTE DOS DESLOCAMENTOS VIÁRIOS URBANOS E OS ASPECTOS GERAIS DA CIDADE DE UBERLÂNDIA/MG

1.1 - O processo de urbanização e a mobilidade como referência diante dos conflitos intra-urbanos

1.2 - Aspectos essenciais para a segurança viária durante os 24 deslocamentos urbanos

1.3 - Os acidentes de trânsito como um dos tipos de violência que ocorre 35 na área urbana

1.4 - Cidades Médias no contexto da urbanização

1.5 - A cidade de Uberlândia: área urbana e o seu sistema de circulação

55 viária

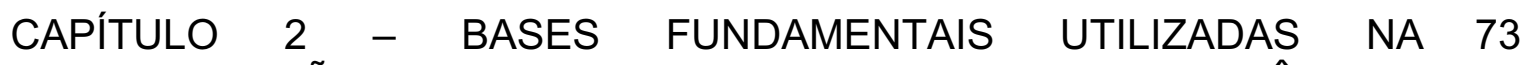
INTERPRETAÇÃO DOS DADOS SOBRE OS ACIDENTES DE TRÂNSITO EM UBERLÂNDIA

2.1 - A importância do geoprocessamento na interpretação dos dados 73 sobre os acidentes de trânsito 
2.2 - Subsídios conceituais para análise dos dados e informações sobre os acidentes de trânsito

2.3 - A base de dados utilizados na interpretação das informações sobre os acidentes de trânsito

2.4 - A identificação dos pontos críticos

80

85

88

CAPÍTULO 3 - OS ACIDENTES DE TRÂNSITO OCORRIDOS NA ÁREA 98 URBANA DE UBERLÂNDIA, 2000 a 2004: ESPACIALIZAÇÃO DOS DADOS E IDENTIFICAÇÃO DOS PONTOS CRÍTICOS

3.1 - As características, causas, perfil dos condutores e a distribuição temporal dos acidentes de trânsito registrados

3.2 - Espacialização dos acidentes de trânsito considerando os números de maior ocorrência - 2000 a 2004, Uberlândia

3.3 - Espacialização dos acidentes de trânsito considerando os números de UPS mais altos - 2000 a 2004, Uberlândia

3.4 - Identificação das vias, trechos e cruzamentos críticos da área urbana 208 de Uberlândia

CAPÍTULO 4 - OS BENEFÍCIOS DA ESPACIALIZAÇÃO DOS DADOS DOS ACIDENTES DE TRÂNSITO FRENTE ÀS ACÕES DO PODER PÚBLICO

4.1 - A interferência das condições da infra-estrutura viária nos acidentes

228 de trânsito

4.2 - Ações do poder público prevendo a redução diante dos acidentes de trânsito

4.3 - Contribuições provenientes da espacialização dos dados dos 248 acidentes de trânsito

CONSIDERAÇÕES FINAIS

REFERÊNCIAS 


\section{INTRODUÇÃO}

O processo da urbanização brasileira desencadeou um crescimento desordenado nas cidades que provocou vários problemas intra-urbanos, atingindo toda a sociedade.

Repercutem da dispersão e do alastramento da área urbana conseqüências como: a degradação das relações sociais e de vizinhança; a maior dependência do veículo motorizado face à sua utilidade; os deslocamentos cada vez mais longos; e o aumento dos custos do uso do transporte e dos tempos de viagem.

Assim, as aglomerações urbanas e as relações humanas vêm instaurando uma complexidade social nunca antes atingida. São exigências que a população estabelece, contribuindo, gradativamente, para dimensões de deslocamentos complexos e distantes daqueles que os órgãos municipais responsáveis podem ou querem oferecer.

Tais deslocamentos intra-viários possibilitam às pessoas e aos automóveis enfrentar conflitos, que, por vezes, levam aos acidentes de trânsito. Eventos estes que somente após o ocorrido são registrados e, assim, contabilizados pelos institutos responsáveis pelo setor. Tais acidentes constituem-se em um grave problema de saúde pública, sendo a causa principal das mortes entre os homens de 15 e 44 anos e a quinta entre as mulheres da mesma faixa etária. O relatório da Organização Mundial da Saúde, para o ano de 2004, indica a ocorrência de 1,2 milhão de mortes por acidentes de trânsito no mundo, com mais de 50 milhões de pessoas feridas.

Diante de tal situação, observa-se que alguns dispositivos de controle de comportamento dos condutores e pedestres funcionam bem apenas com a presença ostensiva da polícia ou de equipamentos de fiscalização eletrônica 
(radares fixos ou móveis, lombada eletrônica, semaforização com câmaras fotográficas), ou quando os condutores supõem que haja a presença policial nas imediações.

Entretanto, tais fatores considerados básicos são condições fundamentais que ofertam a segurança no trânsito. Assim, os veículos, os condutores e os pedestres, o sistema viário, o meio ambiente e o meio ambiente construído receberam suporte normatizado quanto à regulamentação e à fiscalização do trânsito por meio do Código de Trânsito Brasileiro.

Além de assegurar um trânsito mais humano, ao instituir o direito de todos e dever dos órgãos responsáveis, esse Código busca combater as externalidades negativas, assim como a redução dos acidentes de trânsito que envolvem a sociedade, aproximando-a da violência que irradia o sítio urbano.

Ao considerar a violência que ocorre na área urbana, emerge, assim, um difícil, dinâmico e complexo fenômeno a ser compreendido, combatido ou, no mínimo, reduzido em determinados locais quando identificados, são os eventos dos acidentes de trânsito. Sabe-se que há muitas formas de intervir nas causas e nos efeitos da violência. Mas, acima de tudo, é importante que os órgãos, aos quais compete a intervenção sobre esse tipo de violência, bem como a manutenção da segurança viária, conheçam a dinâmica do espaço sobre o qual pretendem viabilizar ações preventivas ou mitigadoras.

Já o aumento do número de veículos circulando nas cidades causa um confronto direto com os pedestres, os quais ficam expostos a possíveis acidentes pelas condições inadequadas e inseguras em relação às outras modalidades, durante seu trajeto, denotando um desequilíbrio de forças em muitos e diferentes momentos.

Por outro lado, nem todos os condutores dos veículos nem mesmo os pedestres estão preparados ou reconhecem seus direitos e deveres, fazendo o 
trânsito nas cidades médias seguir o caminho das características daquele das cidades grandes, quais sejam: nervoso, caótico, mal educado, entre outros.

Mesmo que um número sempre crescente de autoridades conscientize-se dos problemas que envolvem os acidentes de trânsito, seus índices ainda crescem muito. Não obstante, os esforços são desenvolvidos no sentido de dirimir ou, pelo menos, atenuar suas causas e efeitos.

Avalia-se que o custo dos acidentes aproxime de $1 \%$ do PIB em países pobres e $2 \%$ nas nações desenvolvidas. Em termos globais, são gastos U\$ 518 bilhões anuais. No Brasil, estudos revelam que houve uma queda de 20 mil vítimas fatais de acidentes de trânsito, de 1987 para 1998, apresentando, atualmente, em torno de 30 mil mortes/ano no trânsito.

Reconhecendo a situação dos acidentes de trânsito, relevante sob o ponto de vista do planejamento urbano, este estudo visa analisar as características, as causas, o perfil do condutor, a distribuição temporal e a distribuição espacial dos acidentes de trânsito, além de identificar os segmentos e pontos críticos referentes aos registros de todos os tipos desses acidentes ocorridos na área urbana da cidade de Uberlândia, no período de 2000 a 2004.

Por meio do banco de dados obtidos pela SETTRAN, a seleção das informações e o cruzamento dos dados foram direcionados para o conhecimento das características dos acidentes de trânsito, usando os atributos: tipo de veículos envolvidos nos eventos, condições da via e características da via. Para a variável causa dos acidentes, escolheu-se, causa presumível do acidente; para o perfil do condutor, idade, sexo e tempo de habilitação; além da distribuição temporal, com as variáveis: hora, dia, mês e ano; e, para complementar, a distribuição espacial por meio do mapeamento das vias, dos trechos e dos cruzamentos ocorrentes de acidentes de trânsito na área urbana da cidade de Uberlândia. 
Pesquisas realizadas demonstram que as cidades da região do Triângulo Mineiro e Alto Paranaíba perdem população para Uberlândia. De 66 cidades que estão na região, 43 reduzem-se ou crescem menos que a média nacional. Ituiutaba, Cachoeira Dourada, Capinópolis, Prata, Tupaciguara, Monte Alegre, Cascalho Rico são algumas que sofrem o processo de emigração.

Decorrente do alto e rápido crescimento urbano de Uberlândia, estudos sobre as externalidades negativas presentes na área urbana são justificáveis na perspectiva de demonstrar e discutir como determinados fatores ou ações podem minimizar os aspectos que intervêm no desenvolvimento da cidade e de sua população, sendo um deles de importância peculiar, os acidentes de trânsito.

Sendo assim, a cidade de Uberlândia, local de pesquisa deste estudo, pode ser classificada como cidade média, que, entre outras características e dados diversos, propicia a interpretação e a análise dos dados sobre os acidentes de trânsito, em que a estrutura do estudo compreende-se de quatro capítulos, conforme descrito a seguir.

O capítulo 1 trata da discussão sobre o processo de urbanização, que reflete muitos dos impactos e conflitos vividos pela sociedade em função mesmo de suas próprias ações e reações no espaço urbanizado, contribuindo na dinâmica atual das cidades. A realização dos deslocamentos viários gera alguns conflitos cujas conseqüências indignam o homem e seus entes queridos, ao conhecer de perto os acidentes de trânsito considerados como um dos tipos de violência que ocorrem na área urbana. Normas que garantam um deslocamento nas vias urbanas com segurança são expostas, demonstrando seus fins, assim como em quais situações ou locais devam ser utilizadas. Apresentam-se, ao final, aspectos das cidades médias, entre as quais, a cidade de Uberlândia e como acontece a sua circulação viária.

No capítulo 2, estão apresentados os subsídios fundamentais utilizados na seleção e análise dos dados sobre os acidentes de trânsito. Compõem esta parte 
do estudo uma rápida apresentação dos recursos tecnológicos, processos voltados para a informatização de dados em série, assim como a utilização do geoprocessamento. Inserem-se, ainda, vários conceitos fundamentais para o entendimento básico de situações comuns aos eventos e sobre o perfil da base de dados dos acidentes de trânsito disponíveis para o período de 2000 a 2004 . Por fim, demonstram-se os aspectos que determinam a identificação dos locais críticos de ocorrência dos acidentes de trânsito na área urbana de Uberlândia.

No capítulo 3, constam os resultados referentes aos dados dos acidentes de trânsito ocorridos na área urbana da cidade de Uberlândia, selecionados e advindos do Banco de Dados dos acidentes de trânsito provenientes dos Boletins de Ocorrência disponíveis e tabulados pela empresa prestadora de serviços, VERTRAN, da Secretaria Municipal de Trânsito e Transportes (SETTRAN), registrados no período de janeiro de 2000 a dezembro de 2004. Terá a finalidade de analisar as características, as causas, o perfil do condutor, a distribuição temporal e a distribuição espacial dos acidentes, além de identificar as principais vias, trechos e cruzamentos críticos referentes às ocorrências de todos os tipos de acidentes de trânsito registrados na área urbana da cidade de Uberlândia.

O capítulo 4 mostra as condições físicas do sistema viário e a possibilidade de redução ou aumento dos acidentes de trânsito, levando em consideração fatores referentes aos pedestres, aos condutores e aos veículos. Na seqüência, apresentar-se-ão as intervenções viárias que a administração pública realizou na intenção da melhoria referente ao desempenho operacional, humanização no trânsito e melhor acessibilidade ao pedestre, uma vez que, assim, prever-se-á a redução dos acidentes de trânsito ocorridos na área urbana de Uberlândia, além de mostrar os benefícios que a espacialização traz aos dados geográficos.

Nas considerações finais, menciona-se a importância dos resultados espacializados obtidos, relacionados à necessidade que o poder público tem de agrupar informações, apresentá-las e discutí-las, configurando-se em um suporte 
às suas decisões para que possa, assim, garantir à cidade, mais respeito e humanização durante os deslocamentos intra-viários dos cidadãos.

Encontra-se inserido, após os anexos, um mapa base da cidade de Uberlândia de que constam o nome dos logradouros, a identificação dos bairros e, em destaque, o limite do setor territorial definido como setor central, caso haja necessidade de localizar as ruas e avenidas descritas no trabalho. 


\section{CAPÍTULO 1}

\section{O PROCESSO DE URBANIZAÇAO, NORMAS E CONFLITOS DIANTE DOS DESLOCAMENTOS VIÁRIOS URBANOS E OS ASPECTOS GERAIS DA CIDADE DE UBERLÂNDIA/MG}

\section{1- 0 processo de urbanização e a mobilidade como referência diante dos conflitos intra-urbanos}

O crescimento desordenado nas cidades, principalmente nos países em desenvolvimento, vem provocando vários problemas intra-urbanos, que atingem toda a sociedade.

A fase conhecida como inicial do processo de urbanização brasileira, foi a do ciclo da industrialização, a partir de 1930, em que a cidade passou a ter predomínio econômico e político, levando as regiões de maior atratividade a se desenvolverem mais, repercutindo em um crescimento demográfico superior às demais.

Assim, o processo de crescimento populacional urbano, no Brasil, apresentou, nas últimas décadas, uma intensa transformação, quando as cidades brasileiras sofreram uma inversão na taxa de urbanização entre as décadas de 1940 e 80. Nesse período, a população total triplicou e a população urbana se multiplicou.

Em 1940, 74\% da população nacional residiam no campo; em 1991, 77\% habitavam as cidades. Em 1940, as nove maiores aglomerações metropolitanas do país detinham $15 \%$ da população; em 1980, esse número chegou a $29 \%$. Frente às cidades pequenas e médias, as metrópoles brasileiras - com mais de um milhão de habitantes - vêm crescendo menos nas últimas duas ou três 
décadas. Conhecido como desmetropolização relativa, este processo surge, e, sem que o tamanho urbano das metrópoles diminua, são as cidades médias que aumentam em volume e número populacional (SANTOS, 1993).

Uma pesquisa do grupo Instituto Brasileiro de Opinião Pública e Estatística (IBOPE), realizada com exclusividade para a Revista Veja (JUNQUEIRA, 2000), revelou que $41 \%$ dos moradores das capitais e regiões metropolitanas buscam migrar das cidades grandes para as do interior, motivados pelo idílio de ter uma vida mais tranqüila ( $73 \%$ dos entrevistados) ou se expor menos à violência urbana $(43 \%)$.

Os números censitários referentes à população residente urbana e rural no território brasileiro, que abrangem as décadas de 1970 até o ano de 2000, apresentados pelo Instituto Brasileiro de Geografia e Estatística (IBGE) e divulgados pelo Instituto de Pesquisa Econômica Aplicada (IPEA), confirmam, também, o processo de crescimento urbano. Observa-se na tabela 1 que, no início do século $X X I$, a população urbana atinge aproximados $82 \%$.

Tabela 1 - População brasileira residente na área urbana e rural, 1970 a 2000

\begin{tabular}{c|c|c|c|c|c}
\hline População & $\mathbf{1 9 7 0}$ & $\mathbf{1 9 8 0}$ & $\mathbf{1 9 9 1}$ & $\mathbf{1 9 9 6}$ & $\mathbf{2 0 0 0}$ \\
\hline Urbana & 52.097 .260 & 80.437 .327 & 110.990 .990 & 123.076 .831 & 137.953 .959 \\
\hline Rural & 41.037 .586 & 38.573 .725 & 35.834 .485 & 33.993 .332 & 31.845 .211 \\
\hline Total & 93.134 .846 & 119.011 .052 & 146.825 .475 & 157.070 .163 & 169.799 .170 \\
\hline
\end{tabular}

Fonte: IPEA, [2001]

Org: BERNARDINO, A.R., 2005

Tal situação ocorreu e vêm surgindo diferenças entre as regiões do país por estarem sucedidas de uma complexa organização territorial e urbana. Entende-se que o objetivo de construir, ampliar, ordenar, embelezar e sanear as cidades, foi tão decisivo quanto atrativo no processo de migração e busca de melhores condições e qualidade de vida, instituindo modificações na organização territorial e ordenamento urbano. 
Corrêa (1989) afirma que o processo de urbanização se estabeleceu em um novo nível, conhecendo uma aceleração que se consolidou na década de 1980. Nessa década, das regiões brasileiras, somente a região sudeste apresentava um índice de $82,79 \%$, sendo considerada a mais urbanizada.

Por meio do censo demográfico, realizado pelo IBGE para o ano de 2000, a região sudeste apresentou o percentual de 90,5 de sua população residindo na área urbana, como pode ser visto na tabela 2.

Tabela 2 - População regional brasileira por situação de domicílio, 2000

\begin{tabular}{c|c|c|c|c|c}
\hline População & $\begin{array}{c}\text { Região } \\
\text { Norte }\end{array}$ & $\begin{array}{c}\text { Região } \\
\text { Nordeste }\end{array}$ & $\begin{array}{c}\text { Região } \\
\text { Sudeste }\end{array}$ & $\begin{array}{c}\text { Região } \\
\text { Sul }\end{array}$ & $\begin{array}{c}\text { Região Centro- } \\
\text { oeste }\end{array}$ \\
\hline Urbana & 9014365 & 32975425 & 65549194 & 20321999 & 10092976 \\
\hline Rural & 3886339 & 14766286 & 6863217 & 4785617 & 1543752 \\
\hline Total & 12.900 .704 & 47.741 .711 & 72.412 .411 & 25.107 .616 & 11.636 .728 \\
\hline
\end{tabular}

Fonte: IBGE, 2000

Org: BERNARDINO, A.R., 2005

As diversas fragmentações do impacto da modernização sobre o território levaram ao revigoramento do processo de urbanização em todas as regiões brasileiras, mesmo que em níveis e formas diferentes, ganhando um novo conteúdo e uma nova dinâmica por esse processo estabelecido.

Ocorre, assim, uma reorganização do espaço urbano, que vem acompanhada de uma grande especialização de tarefas e de vários tipos de serviços e produtos, não só devido aos aspectos culturais, mas também aos sócio-econômicos. São as especializações do território, que, assim concebidas e originadas, se estabelecem, dando base para a nova divisão territorial do trabalho, que vem consolidar as diferenças econômico-sociais entre as categorias de classes, formando um novo ambiente urbano.

Uma vez consolidada a massa populacional nas cidades - décadas de 1960, 70 e 80 -, a habitação na área urbana passou a uma demanda excepcional, 
ocasião em que os migrantes pertencentes às classe populares buscaram residir nos subúrbios, tendo em vista a redução das despesas. Por outro lado, as classes de alto rendimento familiar buscam fixaram suas moradias fora da área urbana, optando por um envolvente espaço mais "verde" para seus lares. Em quaisquer dos casos, as pessoas foram ficando cada vez mais dependentes dos veículos automotores para satisfazer suas necessidades, assim como realizar suas atividades diárias.

Diante dessa intensificação da urbanização brasileira, o desafio das cidades foi e permanece em enfrentar questões que envolvem, principalmente, condições sociais e econômicas. Dentre as diversidades das questões sócioeconômicas, podemos enfatizar o aspecto da circulação de pessoas, sob as condições de deslocamento, principalmente: casa-trabalho, casa-escola, casaserviços, casa-lazer, entre outros.

As aglomerações urbanas vêm conduzindo as relações humanas a uma complexidade social nunca antes atingida. São exigências que a população estabelece, contribuindo, cada vez mais, para dimensões de deslocamentos complexos e distantes daqueles que os órgãos municipais responsáveis podem ou querem oferecer.

Os processos de reorganização do espaço urbano, em se tratando da circulação das pessoas, ganham níveis e formas diferenciados devido à dinâmica que atinge o cotidiano da população. Surgem dezenas de opções para a aquisição de um veículo automotor, a fim de que seus deslocamentos se façam com mais segurança e rapidez, os quais influenciarão diretamente no aspecto da circulação urbana, que, por sua vez, irá se realizar por meio dos modais: veículos automotores, bicicletas ou motocicletas e a pé, o que conduzirá a grandes desequilíbrios e conflitos interpessoais e intra-urbano.

Spósito (1994), discutindo as principais tendências na dinâmica interna das cidades, refere-se, em primeiro lugar, ao aumento do número de automóveis 
utilizando as mesmas ruas e avenidas que temos hoje. Isso provoca a redução da velocidade média dos veículos, aumentando o tempo real para os deslocamentos, gerando tensão e cansaço nas pessoas.

Acrescenta, o mesmo autor, que uma segunda tendência é a formação de "regiões" dentro das cidades, que se caracterizam por "vidas locais": quem mora no centro terá seu dia-a-dia diferente daqueles que moram em setores da periferia ou subcentros, ou, ainda, daqueles que moram nos setores industriais, e assim por diante.

A terceira e última tendência está baseada na permanência ou aumento da violência causada pela extrema pobreza de milhares de habitantes urbanos que convivem nas mesmas áreas, porém, separados por bairros de moradores possuidores de alta renda e os de baixa renda. Acrescenta-se o exemplo dos condomínios fechados, que se localizam, vez por outra, nas proximidades dos loteamentos populares.

Dessa forma, as conseqüências pela dispersão e alastramento da área urbana são conhecidas: a degradação das relações sociais e de vizinhança; a maior dependência do veículo motorizado face à sua utilidade; os deslocamentos cada vez mais longos; e o aumento dos custos do uso do transporte e dos tempos de viagem.

Assim, o crescimento da população, aliado ao do número de veículos motorizados, exige um desenvolvimento do sistema viário para o transporte urbano que se integre ao reordenamento urbano, da mesma forma que atenda às necessidades de mobilidade da população, mesmo assim, observam-se espaços ociosos nesse processo.

A influência do uso do automóvel na vida da população tornou-se real. As necessidades diárias da população estão envolvidas numa dinâmica em que se procura, a cada dia, realizar várias atividades, particulares e profissionais, 
simultaneamente, com o intuito de atualizar e/ou assimilar informações diferentes provenientes do mundo global e consumista em que se insere, tornando perceptível a sensação de que o tempo é cada vez mais curto. As pessoas sentem a necessidade de que um dia deva ter 48 horas para que concluam todas as atividades que previam para esse dia útil da semana.

Dessa forma, o homem moderno, intrinsecamente mais ansioso e estressado, demonstra-se sensível e, ao mesmo tempo, mal educado em suas ações, mesmo como condutores em seus automóveis, ou na condição de pedestres, ciclistas e/ou motociclistas que trafegam nas vias urbanas, caracterizando o trânsito com problemas que, anteriormente, não causavam grandes impactos no espaço urbano social.

No Seminário de Técnicos e Funcionários em Planejamento Urbano, realizado em Bogotá, outubro/1958, na "Carta dos Andes", foi lançado um conjunto de orientações para o planejamento nos países latino-americanos, em que tiveram destaque, como um dos mais graves problemas das cidades, 0 crescimento urbano descontrolado, ocasionando o surgimento de grandes áreas carentes de serviços públicos essenciais; os transportes coletivos, bem como os equipamentos sociais de saúde, ensino e lazer; além do crescimento das dificuldades administrativas e de manutenção desses serviços, associados à grande carência de habitações, como o surgimento de favelas em um processo contínuo e incontrolável.

Ainda nesse documento, acrescenta-se que, freqüentemente, as autoridades municipais não exercem um efetivo controle do uso da terra, permitindo ao capital privado urbanizar, com fins comercias e até especulativos, segmentos que, no futuro, não poderão ser oferecidos por serviços públicos. Por tais motivos, a distribuição de recursos disponíveis para os serviços públicos vitais deve ter um controle devidamente hierarquizado, que seja: nacional, regional ou estadual, metropolitano, urbano ou municipal, de acordo com um critério de Planejamento Integral. Na condição de enfrentar esse problema, a Carta propõe: 
Devem ser constituídas empresas públicas de caráter regional ou metropolitano pra prover, coordenar, manter e administrar os serviços que a comunidade demanda, enfrentando a realidade de seus custos e fixando tarifas que garantam uma administração sem perdas... (ROCHA FILHO, 1960, p.20).

No $7^{\circ}$ Congresso Nacional da Associação Nacional de Transportes Públicos (ANTP), realizado no Rio de Janeiro em 1989, várias recomendações foram apresentadas pela Comissão de Circulação e Urbanismo, dentre elas, observa-se a relevância do transporte coletivo urbano influenciando a organização do sistema viário, bem como de sua população (Comissão de Circulação e Urbanismo da ANTP, 1989, p.25):

1. Buscar soluções urbanas globais que enfatizem mais as relações sistêmicas, que o compartimento transporte isolado;

2. Romper radicalmente com as práticas usuais que reproduzem o atual modelo de produção de mais transporte como solução para os problemas dos transportes urbanos, investindo o Não-transporte;

3. Promover um reordenamento profundo das atividades urbanas, ocupando os espaços vazios e descentralizando as atividades econômicas e serviços de forma a permitir a redução das distâncias, dos tempos de deslocamento e incrementar a autonomia de cada região;

4. Priorizar os modos de transporte a pé e bicicleta, garantindo o conforto e a segurança de circulação;

5. Recompor o espaço urbano, partindo da redução do tráfego de passagem e criando espaços de convívio, onde a população possa voltar a se apropriar do espaço que foi privatizado pelo uso indiscriminado do automóvel;

6. Priorizar o transporte coletivo em relação ao automóvel, cuja circulação deve sofrer restrições. $O$ transporte coletivo deve ter um padrão de serviços que se constitua numa alternativa segura ao transporte individual; 
7. Romper com a atual política tarifária do transporte coletivo, em que o usuário paga todos os custos do serviço. Alterar a lógica do paga quem utiliza para paga quem se beneficia. Assim, o setor produtivo e os proprietários de imóveis urbanos e de automóveis devem participar do pagamento do serviço de transporte coletivo;

8. Desenvolver ações para substituição dos combustíveis atuais por fontes alternativas menos poluentes e para a redução dos níveis de ruídos dos transportes urbanos;

9. Romper com a compartimentação das administrações como forma de evitar ações setoriais e buscar soluções globais para as cidades.

O IPEA (1990), num amplo trabalho sobre as políticas públicas para a década de 1990, propôs medidas para atingir melhores padrões de desempenho por meio de ações diretas, eficazes e simples, com a finalidade de minorar os problemas do transporte urbano com baixo custo operacional e tarifário, como:

- a criação de corredores exclusivos e semi-exclusivos de ônibus;

- medidas de segurança de tráfego aos pedestres nas áreas de grande movimento e em outras áreas;

- a utilização e fiscalização de tacógrafos em todos os veículos coletivos;

- serviços simples de informações aos usuários;

- racionalização dos itinerários;

- uso de tipos mais adequados de veículos;

- racionalização do planejamento urbano nas interfaces com o sistema viário e demanda de transportes coletivos; e

- competência dos órgãos locais de gerência.

Vasconcellos (2005) discute a questão do uso dos transportes, uma vez que oferecem muitos benefícios, porém ocorre a produção de vários efeitos negativos sobre os meios ambientes natural e social, quais sejam: 
- uso dos recursos naturais: consumo de grande quantidade de energia e de recursos naturais, desde a fabricação do veículo motorizado até a sua destruição;

- poluição: os meios motorizados de transporte causam poluição de forma direta e indireta. As diretas são: poluição atmosférica e sonora, e as de formas indiretas ocorrem por meio dos resíduos deixados pela operação dos veículos, como: pneus velhos, óleo e lubrificantes usados e descartados além da própria carcaça do veículo;

- acidentes de trânsito: grave problema de saúde pública, constituindo a causa principal das mortes entre os homens de 15 e 44 anos e a quinta causa principal entre as mulheres da mesma faixa etária. O relatório da Organização Mundial da Saúde (OMS) para o ano de 2004 indica a ocorrência de 1,2 milhão de mortes por acidentes de trânsito no mundo com mais de 50 milhões de pessoas feridas;

- exclusão dos mais fracos: a disputa pelo espaço de circulação coloca os usuários em conflito permanente. A exclusão econômica, pois, devido à baixa renda dos trabalhadores brasileiros, muitas pessoas não têm como pagar as passagens do transporte coletivo. A exclusão das pessoas que circulam a pé ou de bicicleta, ameaçadas por aquelas que circulam em veículos grandes, e a exclusão das pessoas com limitações na sua mobilidade - os portadores de deficiência física. Esta exclusão é praticamente total nas cidades brasileiras em que seus sistemas viários e as calçadas não estão adaptados ou preparados para atender essas pessoas adequadamente;

- o uso das vias e o congestionamento: as vias e calçadas são utilizadas pelas pessoas deslocando-se a pé ou conduzindo seus veículos automotores. O congestionamento está aumentando muito nas grandes cidades brasileiras, principalmente pelo crescimento vertiginoso do uso dos 
veículos automotores. Por duas razões o sistema viário fica prejudicado; uma devido ao veículo ocupar um grande espaço na via, uma vez que carregam, geralmente, uma ou duas pessoas. A outra é decorrente do uso das vias para estacionar veículos, o que reduz o espaço para circulação;

- estacionamento: muitos veículos passam de 20 a 22 horas estacionados, por ser esta como característica negativa dos automóveis, os quais usam, em geral, o espaço público;

- a destruição e a degradação urbana pela necessidade de obter espaço para o automóvel, muitas cidades ampliam as áreas dedicadas aos veículos e reduzem o espaço para o convívio social, para o lazer, limitando o contato físico.

Os conflitos entre as pessoas, com ou sem veículos, durante os deslocamentos nas cidades, são rotineiramente presenciáveis a qualquer outro cidadão que também esteja circulando, seja a pé, de bicicleta, de motocicleta ou conduzindo um veículo automotor.

Vasconcellos (1996), por sua vez, afirma que a possibilidade de conflitos entre veículos e pedestres ou ciclistas e motociclistas constituem fatores importantes na avaliação das causas por mortes ocorridas no trânsito. Observa-se que o modo de deslocamento por veículo motorizado cria o direito de ameaçar a vida e a saúde de outras pessoas, mesmo que de forma não intencional. Além disso, a falta de segurança viária urbana resulta do uso irresponsável do veículo como um dispositivo capaz de ameaçar outras pessoas e de ocupar violentamente o espaço de circulação.

Os conflitos entre veículos automotores e pedestres, ciclistas e/ou motociclistas que fundamentam as causas dos acidentes ocorridos no trânsito, constituem um grave problema aos países, tanto para os "desenvolvidos" quanto para os em "desenvolvimento". Nestes últimos, os índices de mortes/10.000 
veículos são, várias vezes superiores aos observados nos países industrializados (cf. tabela 3).

Tabela 3 - Mortes no trânsito em países selecionados

\begin{tabular}{c|c|c|c}
\hline País & Ano & Mortes/ano & $\begin{array}{c}\text { Mortes/10.000 } \\
\text { veículos }\end{array}$ \\
\hline EUA & 1984 & 44.241 & 3 \\
\hline França & 1984 & 11.685 & 6 \\
\hline Alemanha & 1984 & 10.199 & 4 \\
\hline Japão & 1984 & 9.262 & 2 \\
\hline Brasil & 1989 & 34.000 & 39 \\
\hline Índia & 1986 & 40.300 & 48 \\
\hline China & 1989 & 50.441 & 141 \\
\hline Nigéria & 1980 & 8.936 & 20 \\
\hline
\end{tabular}

Fonte: Vasconcellos, 1996

Org: BERNARDINO, A.R., 2005

Observa-se, na tabela 3, que os países Brasil, Índia, China e Nigéria apresentaram, para cada 10.000 veículos da frota efetiva, índice de 20, 39, 48 e 141 mortes no trânsito, em detrimento dos países EUA e França, que apresentaram índice de 3 e 6 acidentes com mortes no trânsito para cada 10.000 veículos, respectivamente.

A ampliação sistematizada do sistema viário e da utilização de técnicas que garantam "boas" condições de fluidez fez com que muitas cidades brasileiras fossem adaptadas, nas últimas décadas, para o uso "eficiente" do automóvel, cuja frota cresceu acentuadamente. Alia-se a isto o "marketing" das revendedoras de utilitários, que adotaram estratégias de vendas envolvendo organizações de associações e cooperativas, na conquista de clientes ávidos em obter um veículo automotor. Somam-se a essas condições as facilidades de financiamento oferecidas à população pelas concessionárias na aquisição de um veículo, além da alta produtividade nas montadoras fixadas no Brasil.

No ano de 2002, a produção chegou ao volume de 1.792 .660 unidades dos automóveis, dos comerciais leves e pesados. (ANFAVEA, 2003). 
Verifica-se, ultimamente, que a indústria automobilística, considerando sua oferta e demanda, obtém o monopólio da utilização da circulação viária, percebendo, nas pessoas, progressiva dependência do automóvel em seus deslocamentos, o que Wright (1988) chama de "cultura do automóvel".

O mesmo autor afirma que $40 \%$ a $60 \%$ do solo urbano são utilizados para circular, estacionar, vender, consertar, manter veículos. Em Los Angeles, Estados Unidos, o espaço destinado aos veículos na área central já chega a $70 \%$ de seu total.

Considerando a indústria automobilística brasileira, cuja composição é de empresas multinacionais e nacionais montadoras e de autopeças, que vêm produzindo em torno de 1,3 e 1,8 milhões de veículos/ano, os veículos automotores ultrapassam $80 \%$ da produção, sendo, em sua maioria, movidos à gasolina, o correspondente a $88 \%$ em relação ao diesel e álcool (cf. tabela 4).

Tabela 4 - Produção brasileira de veículos por tipo de combustível, 2000

\begin{tabular}{c|c}
\hline Tipo de Combustível & Produção em 2000 \\
\hline Gasolina & 1.388 .791 \\
\hline Diesel & 185.502 \\
\hline Álcool & 10.052 \\
\hline Total & 1.584 .345 \\
\hline
\end{tabular}

Fonte: GEIPOT,2001

Org: BERNARDINO, A.R., 2005

Azevedo (1992) chama a atenção para as conseqüências dessa denominada "cultura do automóvel", quando esclarece que os veículos produzem uma série de impactos negativos, como a ameaça à segurança e ao conforto para o pedestre, congestionamentos, acidentes de trânsito, dificuldades para estacionar, poluição ambiental, tempos de vida consumidos durante os deslocamentos, além da destruição dos espaços públicos e de convivência.

Para complementar tais impactos, estima-se que, em 2010, poderão ser acrescidos cerca de 50 milhões de habitantes às áreas urbanas e 20 milhões de 
veículos à frota nacional, admitindo-se um crescimento anual de $2 \%$ a $3 \%$ da população urbana e de $4 \%$ da frota de veículos. Caso haja, também, um aumento da renda média do trabalhador, poder-se-á assim, ocorrer o aumento da mobilidade média, prevendo uma alta quantidade de deslocamentos sendo efetoados por pessoa (BRASIL, 2004).

Considerando o crescimento da frota em geral, os índices de mortes/10.000 veículos nas áreas urbanas evidenciaram o agravante no crescimento dos registros dos acidentes fatais ocorridos no trânsito urbano, como pode ser visto na tabela 5:

Tabela 5 - Mortes por acidentes de trânsito/10.000 veículos no Brasil, 1990 a 1999

\begin{tabular}{c|c}
\hline Ano & Mortes/10.000 veículos \\
\hline 1990 & 15,6 \\
\hline 1991 & 13,5 \\
\hline 1992 & 12,6 \\
\hline 1993 & 12,0 \\
\hline 1994 & 12,0 \\
\hline 1995 & 12,2 \\
\hline 1996 & 12,7 \\
\hline 1997 & 12,2 \\
\hline 1998 & 9,9 \\
\hline${ }^{*} 1999$ & 9,2 \\
\hline Fonte: Silva e Kilsztajan,2003, p.153 \\
Org: BERNARDINO, A.R., 2005 \\
(*)óbitos por acidente de trânsito estimados a partir de \\
acidentes de transporte
\end{tabular}

O rápido crescimento do número de veículos no Brasil, considerando o número de habitantes a cada ano, apresentou índice de habitantes/veículos inversamente proporcional, que decresceu ao longo das décadas. Dos 430.000 veículos em 1950, houve um aumento para 3,1 milhões em 1970, ultrapassando a casa dos 25 milhões em 1995 e apresentando-se acima dos 42 milhões de veículos no ano de 2005. Assim, observa-se a proporção de quatro habitantes para cada veículo da frota efetiva brasileira atualmente, tendo em vista que esta unidade de algarismo pode ser alterada em função das diferenças sociais e econômicas que nossas regiões registram, para mais ou para menos (cf. tabela $6)$. 
Tabela 6 - Total da frota brasileira e habitantes/veículos, 1950 a junho de 2006

\begin{tabular}{c|c|c}
\hline Ano & Veículos & Hab/Veículos \\
\hline 1950 & 426.621 & 122 \\
\hline 1960 & 987.613 & 72 \\
\hline 1970 & 3.111 .890 & 30 \\
\hline 1980 & 10.731 .695 & 11 \\
\hline 1990 & 15.932 .848 & 9 \\
\hline 1995 & 25.336 .260 & 6 \\
\hline 2000 & $33.707 .640^{\mathrm{a}}$ & $5^{\mathrm{C}}$ \\
\hline 2005 & $42.071 .961^{\mathrm{b}}$ & $4^{\mathrm{C}}$ \\
\hline jun2006 & $43.578 .352^{\mathrm{d}}$ & $4^{\mathrm{C}}$ \\
\hline
\end{tabular}

Fonte: ANTP,[2003?]

Org: a autora, 2006
(a) - GEIPOT,2001
(b) - DENATRAN, 2005
(c) - dado obtido dividindo o $\mathrm{n}^{\circ}$. habitantes (IBGE) pelo $\mathrm{n}^{\circ}$. veículos
(d) - DENATRAN, 2006

Após 1995, ocorreu uma estabilização econômica no país provocada pela queda da inflação, ocasionando um impacto imediato na demanda de bens, especialmente entre as camadas populares de rendas mais baixas, as quais enfrentaram as desvantagens do período inflacionário.

A estabilidade criou condições financeiras mais seguras à classe média, que se sentiu pronta para a aquisição de veículos novos, devido à flexibilização das formas de pagamento, assim como pelo fim das barreiras à importação que intensificou o crescimento da frota, mesmo que para os automóveis estrangeiros, que, assim sendo, se somaram à frota de veículos circulantes.

Esse crescimento da frota de veículos refletiu-se na queda do uso do transporte público em decorrência da redução da mobilidade, aumento dos tempos de viagem, assim como sérios índices de congestionamento e acréscimo do número de acidentes nas grandes cidades.

Podem-se observar as dez cidades principais, considerando o elevado número da frota de veículos que circulam em seu meio intra-urbano (cf. tabela 7). 
Tabela 7 - As dez cidades brasileiras com maior número de veículos emplacados, 2005

\begin{tabular}{c|c|c}
\hline UF & Município & Frota \\
\hline SP & São Paulo & 4.752 .092 \\
\hline RJ & Rio de Janeiro & 1.611 .679 \\
\hline PR & Curitiba & 930.516 \\
\hline MG & Belo Horizonte & 857.926 \\
\hline DF & Brasilia & 826.302 \\
\hline GO & Goiânia & 587.150 \\
\hline RS & Porto Alegre & 554.067 \\
\hline SP & Campinas & 485.555 \\
\hline CE & Fortaleza & 470.985 \\
\hline BA & Salvador & 441.171 \\
\hline
\end{tabular}

Fonte: DENATRAN, 2005a

Org: BERNARDINO, A.R., 2006

Nesses aspectos, a gestão pública terá grandes desafios, que já são conhecidos hoje, como: oferecer, com qualidade e eficiência aos contingentes populacionais em processo de migração, garantia de segurança durante os seus deslocamentos, ainda que o aumento da frota de automóveis e do seu uso indiscriminado tenda a agravar os problemas de congestionamento, poluição e acidentes nas áreas urbanas.

Observa-se que esse uso incontrolável do automóvel nas cidades prejudica a saúde dos seus habitantes, que sofrem com altos níveis de ruído, contribuindo para o esgotamento das energias não renováveis e para o aumento do efeito estufa.

Além disso, a apropriação do espaço por um veículo, ou melhor, por milhares deles, reduzirá drasticamente o espaço disponível para outros usos urbanos ou para outras modalidades, podendo, também, acrescentar-se a outras causas provocadoras dos acidentes no trânsito.

No contexto da espacialidade das áreas urbanas, as cidades de porte médio, e neste caso a cidade de Uberlândia, apresentam as áreas centrais 
compostas por espaços que concentram atividades e serviços diversos, constituindo-se, assim, na principal zona de atratividade de circulação de pessoas.

Corrêa (1989), discutindo sobre a área central, refere que este espaço torna-se no foco principal, não apenas da cidade, mas também de sua "hinterlândia". Nela, concentram-se as principais atividades comerciais, de serviços, da gestão pública e privada e os terminais de transporte intra-urbanos.

Ferreira (1997), nesse contexto, afirma que a área central da cidade instaura-se como o setor mais importante da cidade, o foco de maior atração e geração de serviços e consumo. Verifica-se, nela, um acentuado e crescente número de conflitos na circulação viária, e as tentativas de minimizá-los sempre evidenciam uma preocupação maior em relação ao tráfego veicular, acarretando uma segregação sócio-espacial, em que os valores que envolvem aspectos relativos à humanização no meio urbano passam a ser desconsiderados em função de privilégios a determinados grupos sociais.

O mesmo autor acrescenta que o cenário de disputa pelo domínio do território urbano evidencia tais privilégios, em que, não raro, aspectos técnicos e sócio-espaciais são suspensos, em função de decisões políticas isoladas que atendem às exigências de interesses particulares de determinados setores da sociedade, estes, em geral, representativos das camadas sociais de alto poder aquisitivo, ou seja, a minoria.

Com isso, a cidade passa a configurar-se em um meio de conturbação de suas relações internas, em que uma das conseqüências consideradas mais agravantes são os acidentes de trânsito. Nesse contexto, acrescenta-se, ainda, que a sinalização, o sistema viário, o sistema de transportes não são suficientemente eficazes para reduzir os impactos dos conflitos urbanos. 
Várias propostas contidas no Informe Mundial sobre Prevenção dos Traumatismos Causados no Trânsito (IMPTCT), sobre intervenções urbanas frente aos principais riscos produzidos pelo trânsito, confirmam possíveis melhorias na segurança do trânsito e resultam em um produto da revisão de iniciativas tomadas por diversos países (OPAS,2004), a saber:

- regular o uso do solo;

- construir caminhos curtos e especiais para usuários vulneráveis;

- restringir os veículos particulares em determinados locais da cidade;

- construir vias únicas para o transporte público;

- estabelecer um sistema progressivo para a obtenção das licenças de condução, ou seja, limitar em idade e horário a condução dos veículos pelos jovens, em que encontram as maiores taxas de colisões;

- projetar e construir vias públicas seguras;

- realizar revisões sobre a manutenção dos veículos públicos e privados;

- estabelecer que haja melhor visibilidade dos veículos;

- proteger os ocupantes dos veículos;

- aplicar suas restrições as normas sobre velocidade e os limites de alcoolemia;

- atender, oportuna e profissionalmente, aos lesionados por veículos a motor no trânsito;

Os agravamentos dos problemas que as cidades brasileiras enfrentam estão largamente relacionados com a questão de trânsito e transporte, ou melhor, com as condições de insegurança quando se circula na área urbana das cidades, constituindo em uma das formas de violência urbana os acidentes de trânsito, que, entre outras desvantagens, conduzem às externalidades negativas, como: os grandes congestionamentos, a poluição do ar, a perturbação do tráfego, os estacionamentos lotados, a redução do valor de propriedade urbana, a conversão de locais públicos em particulares, entre outras. 


\section{2- Aspectos essenciais para a segurança viária durante os deslocamentos urbanos}

1.2.1 - Infra-estrutura urbana como base para assegurar os deslocamentos viários

Para que aconteça a circulação das pessoas e automóveis nas cidades, são utilizadas diferentes infra-estruturas físicas para permitir que os deslocamentos a pé ou por meio dos veículos automotores se realizem com segurança. Entre elas, estão as calçadas, as vias, a sinalização viária, os terminais de transporte público, os corredores de ônibus e as passagens especiais para os pedestres, viadutos, entre outros equipamentos urbanos.

As calçadas são essenciais para a circulação das pessoas a pé. Sabe-se que, mesmo deslocando-se por meio de automóveis, em um determinado momento, será utilizada a calçada e voltar-se-á à condição de pedestre.

As vias são os caminhos físicos preparados para a circulação de pessoas e veículos. Elas incluem as calçadas e, de acordo com o Código de Trânsito Brasileiro (CTB), classificam-se em vias urbanas:

- vias de trânsito rápido: são vias longas, com duas ou mais pistas e sem interrupções semafóricas, permitindo velocidades mais altas; servem ao tráfego volumoso e percorrem áreas urbanas de uso do solo misto;

- vias arteriais: são vias longas, em geral, com duas pistas, e que servem ao tráfego mais volumoso. Têm interseções semaforizadas, percorrendo áreas com uso do solo misto;

- vias coletoras: como o próprio nome diz, são aquelas que "coletam"o tráfego das áreas residenciais ou de atividades e o levam até a via arterial; podem percorrer áreas de uso do solo misto ou residencial; 
- vias locais: são aquelas que servem às áreas residenciais; são mais estreitas e tendem a ter apenas tráfego local, dos moradores.

A sinalização viária é colocada para que as pessoas e os veículos possam se deslocar com segurança, conforto e eficiência, sendo que o trânsito não pode funcionar sem que a sinalização esteja adequada. Os principais sinais definidos pelo CTB são:

- os de posicionamento vertical (regulamentação, advertência, orientação e educação);

- os de posicionamento horizontal (marcas longitudinais, marcas transversais, marcas de canalização);

- a sinalização semafórica (semáforos de regulamentação, semáforos de advertência, dimensionamento dos tempos);

- os dispositivos especiais de segurança (barreiras, dispositivos de controle de velocidade conhecidos como radares fixos ou móveis com câmeras capazes de fotografar infratores);

- o tratamento das interseções - identificado em cinco estágios no uso de sinalização em interseções: interseção de vias locais, com baixa velocidade e pequeno volume de tráfego; interseção com fluxos médios de tráfego e com ocorrência mais alta de acidentes; interseção com fluxos altos de tráfego, requerendo organização, mas que ainda não comporta a instalação de semáforos; e a interseção com fluxos altos de tráfego, nos quais a mini-rotatória não pode ser instalada ou é ineficaz.

Os terminais de transporte público são construções especiais para a operação dos ônibus coletivos. Podem ser rodoviários ou municipais e servem, neste último caso, para as pessoas trocarem de ônibus e atingirem seus destinos. 
Os corredores de ônibus são vias especialmente construídas ou vias arteriais adaptadas para uso exclusivo ou preferencial dos ônibus, com o objetivo de aumentar sua velocidade e sua produtividade.

As passagens especiais para pedestres podem ser as subterrâneas ou elevadas (passarelas) quando a situação de conflito entre pedestres e veículos é grave.

As infra-estruturas físicas constantes nas cidades vêm auxiliar a segurança viária, possibilitando a eliminação de muitos dos riscos que os cidadãos sofreriam, caso elas não fossem utilizadas.

Além disso, alguns fatores são considerados relevantes, quando na busca de medidas conhecidas como corretivas, que podem minimizar os fatores que contribuem em um acidente de trânsito. Gold (1998) destaca três grupos de fatores vinculados:

- ao projeto, à construção da pista e à área de influência - aqui, incluem-se a superelevação inadequada e a distância insuficiente entre o poste e a pista;

- à manutenção do sistema viário - são o estado desgastado do pavimento e a má visibilidade dos sinais de trânsito, considerados sintomas de defeito no sistema de manutenção;

- à natureza - a chuva, que agrava o estado condicional da pista (já escorregadia pela lisura), a vegetação, que camufla a sinalização;

Acresce a esses fatores, os institucionais/sociais, como a regulamentação e a fiscalização pelos órgãos responsáveis do trânsito urbano, o que habitualmente, não é considerado na análise de acidentes, e os pontos críticos. 
Em relação aos condutores, um fator contribuinte é o treinamento inadequado ou inexistente, que muitos condutores carregam no que se refere às técnicas e atitudes de direção defensiva.

Assim, observa-se que alguns dispositivos de controle de comportamento dos condutores e pedestres funcionam bem apenas com a presença ostensiva da polícia ou de equipamentos de fiscalização eletrônica (radares fixos ou móveis, lombada eletrônica, semaforização com câmaras fotográficas), ou quando os condutores supõem a presença policial nas imediações.

Entretanto tais fatores são considerados básicos, cujas condições são fundamentais e ofertam a segurança no trânsito. Os veículos, os condutores e pedestres, o sistema viário, meio ambiente e meio ambiente construído receberam suporte normatizado quanto à regulamentação e à fiscalização do trânsito por meio do CTB.

1.2.2 - Normas para os condutores, passageiros e pedestres, veículos e infra-estrutura viária: o Código Nacional de Trânsito

O CTB, instituído quando promulgada a Lei $N^{\circ} 9.503$, em 23 de setembro de 1997, trouxe inovações para o Estado e a sociedade muito importantes em relação à legislação anterior. Apresenta um envolvimento, não apenas frente à reorganização institucional nos níveis federal, estadual e municipal, mas, principalmente, em relação a sua assimilação pela sociedade brasileira.

Os acidentes de trânsito, a impunidade, a ineficiência e a iniqüidade no uso dos recursos públicos são graves problemas encontrados no trânsito urbano e regional do país, os quais devem ser combatidos com vigor, tendo em vista o novo CTB, que constitui ferramenta essencial para o país atingir e desfrutar de uma melhor qualidade de vida urbana, assim como atingir o desempenho satisfatório de sua economia. 
O CTB entrou em vigor a partir de 22 de janeiro de 1998 e apresenta, logo no $\S 2^{\circ}, \operatorname{Art}^{\circ} 1^{\circ}$ do seu primeiro Capítulo, o que deveria ser de suas mais importantes diretrizes: "o trânsito, em condições seguras, é um direito de todos e dever dos órgãos e entidades componentes do Sistema Nacional de Trânsito (SNT), a estes cabendo, no âmbito das respectivas competências, adotar as medidas destinadas a assegurar esse direito."

O SNT é formado pelo conjunto de órgãos e entidades da União, dos Estados, do Distrito Federal e dos Municípios, que tem por finalidade o exercício das atividades de planejamento, administração, normatização, pesquisa, registro e licenciamento de veículos, formação, habilitação e atualização de condutores, educação, engenharia, operação do sistema viário, policiamento, fiscalização, julgamento de infrações e de recursos e aplicação de penalidades.

A composição do SNT está integrada pelos seguintes órgãos e entidades:

I) o Conselho Nacional de Trânsito (CONTRAN), coordenador do Sistema e órgão máximo normativo e consultivo;

II) os Conselhos Estaduais de Trânsito (CETRAN) e o Conselho de Trânsito do Distrito Federal (CONTRANDIFE), órgãos normativos, consultivos e coordenadores;

III) os órgãos e entidades executivos de trânsito da União, dos Estados, do Distrito Federal e dos Municípios;

IV) os órgãos e entidades executivos rodoviários da União, dos Estados, do Distrito Federal e dos Municípios;

V) a Polícia Rodoviária Federal;

VI) as Polícias Militares dos Estados e do Distrito Federal; e VII) as Juntas Administrativas de Recursos de Infrações (JARI).

O CONTRAN, estabelecido como órgão máximo normativo e consultivo com sede no Distrito Federal, apresenta a seguinte composição (Art.10): 
- um representante do Ministério da Ciência e Tecnologia;

- um representante do Ministério da Educação e do Desporto;

- um representante do Ministério do Exército;

- um representante do Ministério do Meio Ambiente e da Amazônia Legal;

- um representante do Ministério dos Transportes;

- um representante do ministério ou órgão coordenador máximo do SNT;

- um representante do Ministério da Saúde.

Inserido no Capitulo II do CTB, o Art.24 dispõe sobre as competências de todos os órgãos e entidades responsáveis pelo trânsito e que integram o SNT. Dentre elas aos órgãos e entidades executivos de trânsito dos Municípios, compete coletar dados estatísticos e elaborar estudos sobre os acidentes de trânsito e suas causas, além de promover e participar de projetos e programas de educação e segurança no trânsito de acordo com as diretrizes estabelecidas pelo CONTRAN.

O Capítulo III do CTB, intitulado "Das Normas Gerais de Circulação e Conduta", destina normas de conduta a todos os usuários terrestres, quando em circulação no trânsito. Observa-se, neste capítulo, que o condutor de veículo é parte relevante no que se refere ao conhecimento do uso das condições estruturais de sinalização viária, das condições elétricas e mecânicas do veículo, e muito significativas quanto aos cuidados aos pedestres e ciclistas.

O Capítulo IV assegura os direitos e deveres, entre algumas condições de segurança viária e prioridades, aos pedestres e aos condutores de veículos não motorizados.

A eles garante-se a utilização dos passeios/calçadas ou passagens apropriadas das vias urbanas e dos acostamentos da vias rurais para circulação, podendo a autoridade competente permitir a utilização de parte da calçada para outros fins, desde que não seja prejudicial ao fluxo de pedestres. 
Nos cruzamentos das pistas de rolamento, sempre que existirem as faixas ou passagens direcionadas aos pedestres, deverão ser tomadas precauções de segurança, levando em conta a visibilidade, a distância e a velocidade dos veículos.

Onde não houver faixa ou passagem para pedestres, ao cruzar a pista de rolamento, a circulação deverá ser feita em sentido perpendicular ao de seu eixo, e, nas interseções e em suas proximidades, onde não existam faixas de travessia, os pedestres devem atravessar a via na continuação da calçada, observando as seguintes normas:

- não deverão adentrar na pista sem antes se certificar de que podem fazêlo sem obstruir o trânsito de veículos;

- uma vez iniciada a travessia de uma pista, os pedestres não deverão aumentar o seu percurso, demorar-se ou parar sobre ela sem necessidade.

O Capítulo V do CTB está destinado ao cidadão e orienta sobre os direitos de solicitação do cidadão para com os órgãos ou entidades do SNT, no que se refere à sinalização, à fiscalização e à implantação de equipamentos de segurança, assim como poderá sugerir alterações em normas, legislação e outros assuntos pertinentes ao Código. Da mesma forma, cabe ao SNT o dever de analisar as solicitações e responder sobre as possibilidades ou não de atendimento, esclarecer ou justificar a análise efetuada, assim como informar ao solicitante quando tal atividade ocorrerá.

“Da Educação para o Trânsito", tema importantíssimo dentro do CTB, é tratado no Capítulo VI. Logo em seu primeiro artigo prescreve: "A educação para o trânsito é direito de todos e constitui dever prioritário para os componentes do SNT". Este, por sua vez, estabelecerá campanhas anuais de âmbito nacional, que deverão ser promovidas por todos os órgãos ou entidades do SNT, além de promover outras campanhas no âmbito da circunscrição e de acordo com as peculiaridades do local. 
O Art. 76 mostra que campanhas, nas pré-escolas e nas escolas de $1^{\circ}, 2^{\circ} \mathrm{e}$ $3^{\circ}$ graus, deverão, também, ser promovidas por meio de planejamento e ações coordenadas entre os órgãos e entidades do SNT. Ainda salienta a sessão IV que, mediante convênio, promoverá a elaboração de planos de redução de acidentes de trânsito junto aos núcleos interdisciplinares universitários de trânsito, com vistas à integração universidades-sociedades na área de trânsito.

No Capítulo VII, a abordagem refere-se às normas sobre a sinalização de trânsito para condutores e pedestres, que, entre outras indicações, apresenta a classificação dos sinais úteis no trânsito, tais como: verticais, horizontais, dispositivos de sinalização auxiliar, luminosos, sonoros e, inclusive, gestos do agente de trânsito e do condutor. Ainda importante, neste capítulo, é o art. 89 que estabelece a ordem de prevalência diante dos tipos de sinalização, a saber:

- as ordens do agente de trânsito sobre as normas de circulação e outros sinais;

- as indicações do semáforo sobre os demais sinais;

- as indicações dos sinais sobre as demais normas de trânsito.

O Capítulo VIII estabelece normas e regulamentos a serem adotados em todo o território nacional, quando da implementação das soluções adotadas pela engenharia de tráfego, operação, fiscalização e do policiamento ostensivo de trânsito. É importante destacar o Art. 94: "Qualquer obstáculo à livre circulação e à segurança de veículos e pedestres, tanto na via quanto na calçada, caso não possa ser retirado, deve ser devida e imediatamente sinalizado".

Trata o capítulo IX, Dos Veículos, na Seção I, Art.96, a classificação dos veículos, quanto à:

- tração: automotor, elétrico, de propulsão humana, de tração animal e reboque ou semi-reboque; 
- espécie: de passageiros (bicicleta, ciclomotor, motoneta, motocicleta, triciclo, quadriciclo, automóvel, microônibus, ônibus, bonde, reboque ou semi-reboque, charrete); de carga (motoneta, motocicleta, triciclo, quadriciclo, caminhonete, caminhão, reboque, semi-reboque, carroça, carro-de-mão); misto (camioneta, utilitário, outros); de competição, de tração (caminhão-trator, trator de rodas, trator de esteiras, trator misto); especial, e de coleção;

- categoria: oficial, de representação diplomática, de repartições consulares de carreira e organismos internacionais acreditados junto ao Governo brasileiro, particular, de aluguel, de aprendizagem;

$\mathrm{Na}$ Seção II, Da Segurança dos Veículos, o Art. 105 estabelece os equipamentos obrigatórios dos veículos a serem estabelecidos pelo CONTRAN, dos quais: o cinto de segurança e o registrador instantâneo inalterável de velocidade e tempo para os veículos de transporte e de condução escolar; os de passageiros com mais de dez lugares; e os de carga com peso bruto total superior a $4.536 \mathrm{~kg}$; o encosto de cabeça; o dispositivo destinado ao controle de emissão de gases poluentes e de ruído. Para as bicicletas, são obrigatórios a campainha, a sinalização noturna dianteira, traseira, lateral e nos pedais, e o espelho retrovisor do lado esquerdo.

O capítulo XIV dispõe sobre os procedimentos e requisitos para habilitar o condutor de um veículo automotor. A apuração é feita por meio de exames realizados no órgão ou entidade executivos do Estado ou Distrito Federal, do domicílio do candidato.

O Art. 147 indica a ordem em que os exames a que deverão ser submetidos os candidatos:

- de aptidão física e mental;

- escrito, sobre legislação de trânsito; 
- de noções de primeiros socorros, conforme regulamentação do CONTRAN;

- de direção veicular, realizado na via pública, em veículo da categoria para a qual estiver habilitando-se.

No caso de delito de trânsito, o condutor condenado deverá ser submetido a novos exames, para que possa voltar a dirigir, conforme o Art. 160. Nos $\S 1^{\circ} \mathrm{e}$ $2^{\circ}$ desse artigo, estabelece que, em caso de acidente grave, o condutor nele envolvido poderá ser submetido aos exames exigidos neste artigo, a juízo da autoridade executiva estadual de trânsito, assegurada ampla defesa do condutor. A autoridade executiva estadual de trânsito, nessa ocasião, poderá apreender o documento de habilitação do condutor até a sua aprovação nos exames realizados.

O capítulo XV explana sobre as infrações de trânsito, ou seja, se houver a inobservância de qualquer preceito do CTB, da legislação complementar ou das resoluções do CONTRAN, o infrator estará sujeito às penalidades - previstas no Capítulo XVI - e medidas administrativas do Capítulo XVII, indicadas em cada artigo, além das punições prevista no capítulo XIX - Dos Crimes de Trânsito.

Do processo administrativo, autuação, julgamento das autuações e penalidades trata o Capítulo XVIII do CTB.

O CTB incumbiu o SNT - conjunto de órgãos e entidades da União, dos Estados, do Distrito Federal e dos Municípios - da proposição das diretrizes da Política Nacional de Trânsito (PNT), que, submetidas ao CONTRAN, foram aprovadas e encontram expressão nesse documento que o Governo Federal apresentou à nação, em setembro de 2004 (BRASIL, 2004). 
1.2.3 - As diretrizes da Política Nacional de Trânsito (PNT)

A PNT objetiva instituir políticas públicas direcionadas ao trânsito, que foi considerado um dos mais violentos do mundo. Fruto de contribuição coletiva, o governo vê em cada cidadão um protagonista das decisões e soluções para os grandes problemas que assolam a sociedade brasileira.

No enfoque de que "o trânsito é feito de pessoas", intencionou-se a construção dos objetivos e das diretrizes da PNT, que tem o cidadão como seu principal beneficiário além da preservação da vida e do meio ambiente.

A PNT busca atingir cinco grandes objetivos, priorizados em razão de seus significados para a sociedade e para o cidadão brasileiro e de seus efeitos multiplicadores, em consonância com as demais políticas públicas, a saber:

$1^{\circ}$. Valorizar a preservação da vida, da saúde e do meio ambiente, visando à redução do número de vítimas, dos índices e da gravidade dos acidentes de trânsito e da emissão de poluentes e ruídos;

$2^{\circ}$. Efetivar a educação contínua para o trânsito, de forma a orientar cada cidadão e toda a comunidade quanto a princípios, valores, conhecimentos, habilidades e atitudes favoráveis e adequadas à locomoção no espaço social, para uma convivência no trânsito de modo responsável e seguro;

$3^{\circ}$. Promover o exercício da cidadania, incentivando o protagonismo da sociedade com sua participação nas discussões dos problemas e das soluções, em prol da consecução de um comportamento coletivo seguro, respeitoso e não agressivo no trânsito, de respeito ao cidadão, considerado como o foco dos esforços das organizações executoras da Política Nacional de Trânsito;

$4^{\circ}$. Estimular a mobilidade e a acessibilidade a todos os cidadãos, propiciando as condições necessárias para a sua locomoção no espaço público, de forma a assegurar plenamente o direito constitucional de ir e vir, e possibilitando deslocamentos ágeis, seguros, confortáveis, confiáveis e econômicos; e 
$5^{\circ}$. Promover a qualificação contínua de gestão dos órgãos e entidades do SNT, aprimorando e avaliando a sua gestão.

Acrescentam-se nesse documento, as diretrizes gerais, que são: aumentar a segurança de trânsito; fomentar a educação para o trânsito; garantir a mobilidade e acessibilidade com segurança e qualidade ambiental a toda população; promover o exercício da cidadania, a participação e a comunicação com a sociedade; além de fortalecer o SNT.

Para cada uma dessas diretrizes, suas especificidades e detalhamentos foram apresentados com o intuito de mudança de atitude em relação ao trânsito, com fins de alcance em todas as instâncias vinculadas, direta e indiretamente, a esse tema, de forma que o número de acidentes e mortes no trânsito seja revertido. Faz-se necessário que tais direcionamentos cheguem até a sociedade por meio de campanhas educacionais nas ruas da cidade, nas escolas, nas empresas, nas organizações particulares ou públicas, instituições públicas de todas as esferas - municipal, estadual e federal.

Além de assegurar um trânsito mais humano, ao instituir o direito de todos e dever dos órgãos responsáveis, o CTB busca combater as externalidades negativas, assim como a redução dos acidentes de trânsito que envolvem a sociedade, aproximando-a da violência que adentra o recinto de vivência do homem, a cidade.

\section{3 - Os acidentes de trânsito como um dos tipos de violência que ocorrem na área urbana}

Considera-se a violência um dos temas priorizados nos estudos urbanos. Sua demanda busca um vasto entendimento, que se direciona a uma prática eficiente de combate e/ou de prevenção. 
Houaiss e Villar (2001) conceituam a palavra violência, afirmando que é originária do latim violabilis e significa:

1.Qualidade do que é violento[...]. 2. Ação ou efeito de violentar, de empregar força física (contra alguém ou algo) ou intimidação moral contra (alguém); Ato violento, crueldade, força [...]. 3. Exercício infinito ou discricionário ilegal de força ou de poder [...]. 7. JUR. Constrangimento físico ou moral, exercido sobre alguém para obrigá-lo a submeter-se à vontade de outrem; Coação (HOUAISS; VILLAR, 2001, p.2866).

Souza (2000) reflete sobre o individualismo, a desconfiança, a guetoização, o abandono e a desvitalizaçao dos espaços públicos que são componentes que impede a mobilização e intensifica o processo de urbanização, que traz consigo situações de predisposições à violência.

A vida urbana atual tem se tornado cada vez mais individualizada, com ritmos e características próprias, que diferem de outros momentos da história da sociedade. Souza (2000) refere ao individualismo existente na sociedade, um fenômeno, também, provocado pelo sentimento de insegurança vivido pela população, e, que é considerado como a causa da fragmentação do tecido sociopolítico espacial.

Assim sendo, é sobre a área da saúde que recai o maior ônus das conseqüências da violência, a saber: os cuidados com os feridos; a contabilização das mortes; e os aspectos importantes vinculados às seqüelas, não poucas vezes, irreversíveis.

Para o Código Internacional de Doenças (CID), 10ª . Revisão, a OMS passou a prever um grupo maior de eventos - o dos acidentes de transporte definido como todo acidente que envolva veículo destinado (ou usado no momento do acidente), sobretudo, para o transporte de pessoas ou mercadorias de um lugar para outro. Conhecido como "CID 10", recebeu a identificação da Classificação Estatística Internacional de Doenças e Problemas Relacionados 
com a Saúde. No Volume I, capítulo 20, encontram-se as "causas externas de morbidade e de mortalidade", em que se inserem todas aquelas que possuem ligações afins com qualquer evento referente a transportes em geral, e são úteis quando na identificação do tipo do acidente para a área médica. Esses acidentes estão especificados em categorias obedecendo aos seguintes agrupamentos (MELLO JORGE e KOIZUMI, 2006):

-Pedestre traumatizado em um acidente de transporte;

-Ciclista traumatizado em um acidente de transporte

-Motociclista traumatizado em um acidente de transporte

-Ocupante de triciclo motorizado traumatizado em um acidente de transporte

-Ocupante de um automóvel traumatizado em um acidente de transporte

-Ocupante de uma caminhonete traumatizado em um acidente de transporte

-Ocupante de um veículo de transporte pesado traumatizado em um acidente de transporte

-Ocupante de um ônibus traumatizado em um acidente de transporte

-Outros acidentes de transporte terrestre

-Acidentes de transporte por água

-Acidentes de transporte aéreo e espacial

-Outros acidentes de transporte e os não especificados

Silveira e Ribeiro (2006) explicam que as lesões procedentes dessas causas externas, intencionais ou não, são chamadas indistintamente de "trauma", e a vítima da violência, de "politraumatizado", e, para fins de estatística de morbidade, encontram-se classificadas no capítulo entitulado "Lesões, Envenenamentos e Algumas Outras Conseqüências de Causas Externas" no CID10. 
Para todas essas categorias, foram instituídos códigos alfa-númericos, classificando e identificando cada um, além de serem difundidos internacionalmente.

Dada a violência na área urbana como um processo amplo, que vai além da criminalidade, esta "surge e se avoluma à medida que as cidades crescem e se tornam mais complexas, mais dominadas pela multidão [...] e pela anomia". (ABRANCHES, 1994 apud FERREIRA e PENNA, 2005, p.66).

Sabe-se que o processo de urbanização acelerado recebeu influência do processo capitalista, cujo ambiente revelou-se favorável à violência. Que a vida nas cidades grandes, notadamente, é marcada por riscos a todo instante, inevitáveis por vezes. Morais (1990) acrescenta que a violência urbana produz disfunções no organismo, que tendem a gerar situações de constrangimento às pessoas, provocando desequilíbrio da pressão interna do sistema arterial e o medo, criando uma cadeia de outros sintomas que se instalam simultaneamente a esses.

O jornal Correio, de Uberlândia, publicou uma reportagem, revelando que o crescimento da violência urbana nas cidades brasileiras tem afetado a expectativa de vida de seus habitantes.

Essa reportagem apresentou informações do IBGE/RJ, em que as mortes por causas externas, particularmente aquelas relacionadas com os homicídios, reduziram em quatro anos e um mês a esperança de vida dos homens ao nascer. Para o Brasil, a perda é de dois anos e, entre os paulistas, de três. A reportagem informa, ainda, que, entre 1980 e 2000 ocorreram dois milhões de mortes por causas externas no Brasil, sendo que 598,4 mil foram causadas por homicídios.

Nesse mesmo período, aumentaram as taxas de mortalidade por homicídios para ambos os sexos, apresentando um crescimento de 130\%, e passaram de 11,7/100.000 habitantes para 27/100.000 habitantes. O presidente 
do IBGE acrescenta que o aumento da violência é conseqüência de uma junção de fatores econômicos, geográficos e sociais. Considerou-se, ainda, nessa reportagem, que, nos últimos 20 anos, houve transformações que não levaram à expansão do emprego. Além disso, o aumento da população ficou concentrado nas regiões metropolitanas, onde as condições de habitação ficaram, geralmente, precárias. Tudo isso contribuiu na intensificação da violência. (VIOLÊNCIA...,2004).

Para Francisco Filho (2004), a violência participa cada vez mais dos temores de quem habita as cidades, e proporciona um comportamento no qual o medo ocupa o topo de suas inquietações. Para o autor, viver, hoje, na cidade é:

\footnotetext{
Viver o medo, a incerteza de chegar em casa ao final do dia, se nossos filhos voltam ilesos depois de se aventurarem pela cidade, seja em busca de divertimento, ou de conhecimento. Conhecer essa realidade, entender como esse processo nasce, se desenvolve e se espacializa nas nossas metrópoles é de grande importância, pois, sem isso, estaremos fadados a viver em espaços cada vez mais segregados, fechados dentro de uma realidade que não vai além dos muros e das cercas eletrificadas. (FRANCISCO FILHO, 2004.p.1)
}

Discutindo o "território da violência", Ferreira e Penna (2005) indicam que a violência, como objeto de análise, é aquela ligada ao crime organizado, que inclui o tráfico de drogas, armas, a formação de quadrilha, os seqüestros, os atentados, os assaltos, os roubos, os homicídios etc.

Ainda em seus estudos, as autoras apresentam a violência em todas as suas manifestações, tomando como dado o homicídio. Mesmo que a violência cotidiana termine em morte, a morte revela a violência levada ao extremo. Os homicídios são identificados como a parte visível de uma realidade complexa.

Por outro lado, o dado de mortalidade por homicídio, a partir do registro dos óbitos pelos órgãos que detém as informações sobre mortalidade, é mais seguro 
que as ocorrências policiais, nem sempre registradas pelas vítimas, e que permitem a comparação.

Consideram-se inúmeras as formas como se pratica a violência, algumas passíveis de controvérsia. Na Revista do Instituto de Medicina Social e de Criminologia de São Paulo (IMESC), Marlet (1998) discute sobre estudos criminológicos e afirma que em todo e qualquer crime, há dois sujeitos: o ativo e o passivo ou vítima. Muitos estudos voltam-se quase que exclusivamente para os autores, esquecendo-se das vítimas, talvez porque a sociedade se preocupe mais com o autor, que a ameaça com sua conduta, do que com a vítima, que sofre as conseqüências do ilícito penal.

Nos laudos necroscópicos do IML de São Paulo, as mortes violentas são classificadas em:
a) homicídios;
b) suicídios;
c) atropelamentos;
d) acidentes de trabalho;
e) acidentes que não de trabalho;
f) afogamentos;

Os resultados desse estudo, ao longo de 19 meses, indicaram que, na Grande São Paulo, considerando a média mensal, observou-se o aumento médio do número mensal de homicídios, atingindo 12 casos. Já para os suicídios, manteve-se constante, em torno de aproximados 85 casos mensais. Para os atropelamentos, detectou-se que a média das mortes por atropelamentos estaria em aproximados 147 casos por mês. O número mensal de óbitos por acidente do trabalho tem crescido na Grande São Paulo, com 15 casos mensais. Para os casos de afogamentos, na mesma região, embora com grande acréscimo nos meses mais quentes, a média mensal atingiu os 37 . 
Ao final desse estudo, Marlet (1998) conclui que o número cada vez maior de veículos automotores circulantes pode explicar o aumento progressivo de mortes por atropelamentos.

Utilizando-se o índice de perda de anos potenciais de vida, em que se pondera o número de mortos pela diferença entre a expectativa de vida da população e a idade da morte, as perdas superam as doenças cardíacas e o câncer, visto que, em média, a vítima do acidente de tráfego tem apenas 33 anos, contra 52 para a vítima do câncer e 55 para as fatalidades cardiovasculares.

Dados obtidos por meio da mídia televisiva (FANTÁSTICO, 2004), em reportagem sobre as pesquisas realizadas pela OMS, indicaram que 3,3\% dos homens entre 18 e 34 anos sofreram lesões por instrumentos: facas e armas. Já as ocorrências neste mesmo gênero indicaram que $7,9 \%$ desses homens sofreram violência mediante o envolvimento em acidentes de trânsito, exprimindo que a violência urbana no trânsito supera a violência por armas de fogo e instrumentos domésticos.

Felix (2003) ressalta que a relação entre crime e insegurança determina a "geometria espacial", que ultrapassa a relação entre classe econômica e condições físicas do ambiente, sendo mais forte a relação entre o modo como as pessoas sentem o ambiente urbano e suas contradições. Acrescenta que a manifestação espacial do crime altera valores e percepções espaciais, deteriora os espaços urbanos, altera os níveis de concentração ou esvaziamento e cria espaços do medo.

No âmbito social, os desequilíbrios no ambiente familiar, no trabalho, no convívio social estão conjuntamente interligados às causas dos acidentes de trânsito. Já no viés econômico, a vítima que se afasta de suas atividades deixa de produzir por um período em que ainda poderia contribuir para o mercado de trabalho, o que significa tanto uma perda pessoal como social. Mas, a partir desse momento, passa a depender do Estado, ocasião que é restrita a alguns casos em 
que a previdência ampara os cidadãos que sofreram acidentes, após realizada a perícia médica junto ao órgão do governo.

De acordo com Menezes (1992), 95\% dos acidentes de trânsito ocorrem com pedestres nas áreas urbanas, e, desses, a metade em áreas centrais da cidade. Locais estes de atratividades várias em que o volume de pessoas sempre é descomedido.

Ribeiro (1993) retrata que o aumento do volume de veículos em circulação tem causado aos pedestres um confronto direto. Existe um grande desequilíbrio de forças, e como há, de certa forma, grande flexibilidade para os deslocamentos a pé, aqueles, em diferentes ocasiões ficam expostos a acidentes durante os seus deslocamentos por não terem condições adequadas e seguras durante seu trajeto em relação às outras modalidades.

Por outro lado, nem todos os condutores dos veículos nem mesmo os pedestres estão preparados ou reconhecem seus direitos e deveres, fazendo o trânsito nas cidades médias seguir o caminho das características das cidades grandes, quais sejam: nervoso, caótico, mal educado, entre outros.

As cidades devem estar sob um propósito de planejamento urbano que melhor abrigue todo um sistema de atividades que possa desenvolver-se numa área urbana. Entende-se sistema de atividades o deslocamento que fazemos diariamente, como: ir ao trabalho, à escola, deixar as crianças na escola, ir ao supermercado, à área central, utilizar os serviços oferecidos à comunidade, ir ao "shopping center", utilizando automóvel, bicicleta, motocicleta, transporte público coletivo ou a pé, para, assim, realizar todos esses deslocamentos e do mesmo modo proceder no retorno.

Como grandes atrativos das atividades geradoras de tráfego, as áreas centrais urbanas demonstram proporcionalidade entre o aumento da frota e o aumento do número de acidentes. Após certos níveis, não é possível controlar, 
ou, ao mesmo tempo, estimar o que possa ocorrer, em termos de se chegar ao caos urbano a partir dos incontáveis conflitos entre pessoas, veículos e infraestrutura viária.

Acrescenta-se que os diversos acidentes de trânsito em que a multiplicação dos veículos automotores e o seu crescente e incorreto uso têm provocado, além da circulação dos ônibus coletivos cada vez mais intensa nas áreas centrais, venham contribuir para a geração da violência no tráfego urbano, considerando os graves acidentes ocorridos no trânsito, tendo como conseqüências os feridos e/ou mortos.

Como problema de saúde pública, os acidentes de trânsito, principalmente nos fins da década de 1990 e início do século XXI, ficaram passíveis de ser tratados como doenças epidêmicas, em decorrência do número de feridos e mortes registrados.

No Brasil, em geral, as principais causas das mortes violentas são os acidentes de trânsito e os homicídios. A violência atinge pessoas da faixa etária produtiva, e, segundo o IBGE, quase $75 \%$ dos óbitos na idade entre 15 e 19 anos são por causas violentas. Os acidentes e violências aparecem no primeiro grupo de causas de morte, desde os 5 até os 39 anos, sendo que, na faixa de 15 a 19 anos, foram responsáveis por praticamente 65\% dos óbitos em 1991 no Brasil. Entre crianças e adolescentes até 14 anos de idade, os acidentes de trânsito, principalmente os atropelamentos, têm maior impacto na mortalidade do que os homicídios. Na faixa etária de 15 a 24 anos, em 1998, a razão dos óbitos por causas externas com relação a todas as outras causas, foi de $50 \%$ em Belém, 67\% em Recife, 60\% em Cuiabá, 69\% no Rio de Janeiro e 74\% em São Paulo (SILVEIRA, 2002).

Diariamente, um número sempre crescente de autoridades conscientiza-se dos problemas que envolvem os acidentes de trânsito. Não obstante, os esforços 
desenvolvidos no sentido de dirimir ou, pelo menos, atenuar suas causas e efeitos, paralelamente, seus índices ainda crescem muito.

Pode-se observar, nas informações obtidas por meio do Relatório Executivo IPEA/ANTP(2003), que, de 1961 a 2000, os feridos no trânsito multiplicaram-se por quinze e o de mortos por seis. $O$ índice de mortes/100 mil habitantes cresceu nas duas primeiras décadas podendo verificar, também, 0 crescimento do número de feridos, embora, se note uma queda do índice de mortos/veículos após 1991. (cf. tabela 8).

Tabela 8 - Acidentes de trânsito no Brasil, 1961 a 2000

\begin{tabular}{c|c|c|c|c}
\hline Ano & Feridos & Mortos & $\begin{array}{c}\text { Mortos/100 } \\
\text { mil hab. }\end{array}$ & $\begin{array}{c}\text { Mortos/ 10 } \\
\text { mil veículos }\end{array}$ \\
\hline 1961 & 23.358 & 3.356 & 4,6 & 53,6 \\
\hline 1971 & 124.283 & 10.692 & 11,1 & 34,4 \\
\hline 1981 & 243.001 & 19.782 & 15,9 & 17,0 \\
\hline 1991 & 248.885 & 23.332 & 15,1 & 11,3 \\
\hline 2000 & 358.762 & 20.049 & 11,8 & 6,8 \\
\hline
\end{tabular}

Fonte: IPEA/ANTP, 2003.

É imprescindível a análise das condições que reflitam a realidade da perda sócio-econômica que o acidente de trânsito causa à comunidade. Quaisquer medidas que visem à redução de suas conseqüências deverão receber a necessária atenção, em razão do fim a que se propõem.

Durante os anos 1990, medidas como a obrigatoriedade do uso do cinto de segurança e a fiscalização e controladores eletrônicos de velocidade nas vias urbanas, com o CTB instituído, auxiliaram na redução do número de mortes e na melhoria da segurança no trânsito. Poderiam, assim, fazer parte deste leque e serem compulsórios os aspectos institucionais, informacionais, ambientais adequação do espaço público e reordenamento urbano - e culturais, em que o comportamento das pessoas como cidadãos pudessem ser colocados em prática para todas as relações sociais. 
A segurança viária tem recebido relativamente pouca atenção, se relacionada às perdas sócio-econômicas observadas em estudos sobre ela.

Se se considerassem as vidas perdidas e houvesse uma análise num contexto mais amplo, constatar-se-ia, assim, uma outra realidade pelas perdas sócio-econômicas provenientes dos acidentes causados por uma exclusiva culpa pessoal. Além do que, afora o desperdício humano, o acidente aciona a mola propulsora noutros processos, tais como; hospitais, centros de reabilitação, oficinas de reparos de autos, companhia de seguros, previdência social, entre outros. Estes itens, se calculados e mostrados em números absolutos, deixariam todos atônitos por sentir mais de perto as perdas, dada a sua extensão.

Ainda, repercute dos acidentes de trânsito o deslocamento do trabalho assistencial para o tratamento das vítimas agudas e crônicas do trânsito e das demais violências, quando, até pouco tempo, o envolvimento, a disponibilidade e a atenção dos profissionais e servidores da área da saúde estavam direcionados a outras demandas (CARVALHO NETO, 1996). Esta situação aponta para a existência de uma "economia da violência" em que os acidentes de trânsito ocupam lugar importante.

Em um estudo que os autores avaliam o custo do atendimento emergencial às vitimas de violência, no Rio de Janeiro, no ano de 1997, no Hospital Municipal Miguel Couto, observou-se que os atropelamentos absorveram quase a metade $(45,8 \%)$ dos recursos disponíveis às causas violentas (DESLANDES, et al., 1998).

Em 2000, segundo a OMS, os acidentes de trânsito, em todo o mundo, custaram à vida além de 1,2 milhões de pessoas, sendo que produziram uma legião de 50 milhões de feridos, muitos dos quais carregarão seqüelas pelo resto de suas vidas. Para países subdesenvolvidos ou em desenvolvimento como o Brasil, o problema é especialmente grave, pois, neles, concentram-se $85 \%$ dessas mortes em acidentes automobilísticos. O impacto econômico dos acidentes também é significativo. 
Estima-se que o custo dos acidentes varie de 1\% do PIB em países pobres a $2 \%$ nas nações desenvolvidas. Em termos globais, são U\$ 518 bilhões anuais (FOLHA DE SÃO PAULO, 2004).

Outras estimativas evidenciam que um acidente de trânsito sem vítimas, em São Paulo, pode custar U\$1.400 dólares; se apresentar vítima grave, 17.000 dólares; e, se houver um morto as cifras chegam a 141.000 dólares (SAEZSAAVEDRA et al. apud CONCHA-EASTMAN e ACERO-VELÁSQUEZ, 2006)

Para Wright (1989), a importância econômica desses acidentes é mostrada pelos seguintes fatores:

- três quartos das vítimas fatais são do sexo masculino, e, juntamente com aquelas do sexo feminino, tendem a estar na fase mais produtiva das suas vidas; - algo entre $10 \%$ e $20 \%$ da frota nacional de veículos, anualmente, envolve-se em acidentes; e

- três quartos dos leitos hospitalares na área de ortopedia e traumatologia são ocupados por vítimas de acidentes de trânsito, sendo quase todos os atendimentos pagos pelo Ministério da Previdência Social e Assistência Social.

Oliveira (2001, p.20) questiona e apresenta alguns dados:

Quanto vale uma vida? No trânsito vale U\$ 130 mil. Esse é o custo social de uma morte em acidente de tráfego, seja num dos cruzamentos de Santo André (SP) ou qualquer outra parte do país. Se a questão fosse apenas dinheiro, Santo André poderia comemorar uma economia de U\$ 15,4 milhões desde 1998, quando criou programa de excelência e adotou fiscalização eletrônica na esteira do Código de Trânsito Brasileiro... Entre 1993 e 1997, o número de mortes no trânsito de Santo André, então sem radares, aumentava $20 \%$ a cada ano.

Em geral, as medidas que poderiam efetivar a redução dos acidentes no trânsito são conhecidas, por exemplo: fazer cumprir as leis e mecanismos que 
limitem a velocidade dos veículos e o consumo de álcool por motoristas, fazer com que o cinto de segurança seja utilizado por todos os passageiros e melhorar a segurança nas ruas, avenidas e estradas com sinalizações mais precisas, além dos próprios automóveis estarem em condições adequadas para o seu uso.

A Empresa Brasileira de Planejamento de Transportes (GEIPOT) mostrou que são mortos, anualmente, em acidentes de tráfego, cerca de 50 mil brasileiros, número equivalente ao total acumulado de soldados americanos mortos na Guerra do Vietnã. É ainda maior o número de feridos: segundo os (subestimados) dados federais, há cerca de 350 mil feridos/ano nos acidentes brasileiros, contra 300 mil americanos feridos (total acumulado) no fim da Guerra do Vietnã (GEIPOT, 1987).

Informações recentes (cf. tabela 9) apresentam uma queda de 20 mil vítimas de acidentes de trânsito, de 1987 para 1998, apresentando o número de 30 mil vítimas/ano. Observa-se que o número de vítimas de acidentes, a partir de 1998, até 2000 reduziu, o que coincide com a implementação do CTB, a que pode ser dada razão da queda.

Tabela 9 - Número de vítimas de acidentes de trânsito, 1998 a 2002, Brasil

\begin{tabular}{c|c|c|c|c|c}
\hline \hline Ano & $\mathbf{1 9 9 8}$ & $\mathbf{1 9 9 9}$ & $\mathbf{2 0 0 0}$ & $\mathbf{2 0 0 1}$ & $\mathbf{2 0 0 2}$ \\
\hline Total de vítimas & 30.955 & 30.108 & 29.638 & 30.993 & 33.256 \\
\hline Masculino & 24.607 & 24.092 & 23.931 & 25.302 & 27.100 \\
\hline Feminino & 6.317 & 5.999 & 5.687 & 5.677 & 6.138 \\
\hline
\end{tabular}

Fonte: IPEA/ANTP, 2003

Org: BERNARDINO,A. R., 2006

As causas que decorrem de um número crescente de vítimas em acidentes de trânsito para as cidades de porte médio, como no caso de Uberlândia, podem estar entre:

a) estresse dos condutores que têm seu tempo escasso para realizar todas as atividades diárias em função do acúmulo de serviços e atividades tanto profissional quanto particular;

b) excesso de velocidade e imprudência dos condutores quando nos deslocamentos viários; 
c) insistência dos pedestres em travessias perigosas, ou seja, eles não utilizam as faixas a eles destinadas para realizar as travessias com segurança;

d) falta ou má sinalização viária dificultando o deslocamento de todos os condutores de qualquer modalidade de transporte, e também dos pedestres;

e) grande oferta de veículos e utilitários presente nos últimos anos, ocorrendo o crescimento exagerado da frota devido às condições de aquisição de veículos automotores, em função dos vários empréstimos, financiamentos, entre outras condições facilitadas;

f) inexistência ou falta de fiscalização para conter os condutores que não estão preparados para estar no trânsito, quer sejam os que "perderam" a carteira de habilitação por excesso de pontuação devido às infrações cometidas, para os que não renovaram a carteira de habilitação e para os que utilizam veículos sem as condições de segurança e normatização;

g) saturação do sistema viário, devido à área atratora e geradora de um grande número de serviços destinados à população urbana, não foi, ainda, ampliada ou reordenada em função de fatores políticos e apolíticos;

Entretanto fatores como; opinião da população sobre as condições de segurança nos sistemas viários de circulação urbana, sobre a segurança durante os deslocamentos e o posicionamento da mídia, não são consideradas causas diretas na expansão da violência urbana, mas adentram o sítio urbano sem pedir licença e contribuem para engendrar um ambiente favorável ao seu crescimento e agravamento.

Para Gold (1998), existem quatro grupos básicos de fatores que estão freqüentemente correlacionados e podem ser determinantes em um acidente, a saber:

- fatores humanos;

- fatores relativos ao veículo; 
- fatores relativos à via/meio ambiente e ambiente construído;

- fatores institucionais/sociais.

Os fatores humanos referem-se ao comportamento das pessoas envolvidas no acidente, como: tensão nervosa, decorrente dos problemas de trabalho ou particulares, ingestão de álcool, desconhecimento do trajeto, distração devido à conversa com os amigos ou ao telefone, poluição visual presente nas áreas centrais das cidades, etc.

Tudo isso contribui para diminuir os reflexos do condutor que "terminou freando tardiamente". Ademais, sabe-se que, desses fatores, o único que poderia aparecer num boletim de ocorrência é o de que o condutor se encontrava alcoolizado. Os demais somente poderiam surgir, caso houvesse uma entrevista com o condutor ou passageiro sobrevivente.

Os fatores relativos ao veículo dizem respeito às inadequações no estado operacional dos veículos envolvidos em acidentes como: pneus ou amortecedores gastos, problemas de direção, mau ajuste dos freios, limpadores de pára-brisas enguiçados etc.

Os fatores relativos à via/meio ambiente e meio ambiente construído referem-se a todos os fatores vinculados diretamente às características da via, da sinalização e das áreas mais próximas da via no momento do acidente, que podem ser: curva, pavimento liso, vegetação cobrindo as placas de sinalização e chuva.

Além disso, tem-se a insatisfação dos usuários do transporte coletivo urbano, como a falta de confiabilidade nos horários e de segurança, o baixo nível de conforto durante os seus deslocamentos, a que se somará à vontade de os 
usuários buscarem adquirir um veículo automotor, que alimentará o processo de crescimento da frota de veículos que circulam nas cidades.

Sabe-se que os acidentes de trânsito contribuem, em grande escala, como uma das principais causas do desperdício de recursos materiais, humanos e administrativos, bem como das perdas sociais e econômicas que provêm, em geral, da má conservação e escassez na manutenção dos equipamentos urbanos e do sistema viário.

\section{4 - Cidades Médias no contexto da urbanização}

As cidades médias brasileiras apresentaram um dinamismo demográfico considerável nas últimas décadas. Entre 1970 e 1996, essas cidades tiveram um ritmo de crescimento superior ao observado para o conjunto dos centros urbanos do país, tendo ampliado a sua participação na população urbana de cerca de $9 \%$ para $14 \%$ nesses 26 anos.

Referente ao termo utilizado "cidades médias", num primeiro momento, evidencia-se que elas se caracterizam pelos critérios quantitativos de número populacional. Todavia algumas discussões teóricas sobre a questão demonstram a existência de divergências quanto à conceituação dessas cidades.

Assim, ocorre que essas aglomerações urbanas apresentam uma série de variáveis, tanto quantitativas, quanto qualitativas, que as determinam como médias.

Para Soares (1999, p.56), as cidades médias são caracterizadas: 
...por possuir altas taxas de crescimento, tanto populacional como econômico; por sua geração de empregos, que absorvem números expressivos de força de trabalho; por apresentarem altos índices de qualidade de vida; por sua especialização econômica, particularmente no que diz respeito à diversificação e concentração de atividades comerciais e de serviços; pela existência de redes de transporte, comunicação e informação modernas; enfim, são difusoras de inovações e desenvolvimento para as cidades sob sua área de influência.

As disparidades regionais no espaço brasileiro acarretam dificuldades para uma definição de cidade média. Assim, de maneira ainda muito preliminar, a cidade média, para Pontes (1985, p.1), viria a ser o "organismo em condições de atuar como suporte às atividades econômicas de sua hinterlândia".

Com relação aos critérios demográficos, para a definição do tamanho das cidades de porte médio no Brasil, o IBGE considera que elas devam possuir uma população entre 100.000 e 500.000 habitantes. No entanto, para a ONU, considerando a realidade latino-americana, as cidades médias são aquelas com população entre 100 mil e 1 milhão de habitantes. Porém esse critério não evidencia as dimensões econômicas, políticas, sociais e culturais, tendo-se sempre que respeitar tais atributos.

Por meio da publicação da Agenda 21 brasileira na temática sobre as cidades sustentáveis, avaliou-se que as cidades de porte médio têm diversificado sua economia e consolidado seu papel de prestadoras de serviços, seja pelos depósitos e pela circulação dos consideráveis proventos da agricultura circundante, seja, no sudeste e sul, em virtude da elevação de demandas em consumo e cultura, decorrente da criação de numerosos cursos de ensino superior. Elas ainda não apresentam, por uma questão de escala, os efeitos dramáticos do crescimento nas metrópoles ou grandes conurbações. 
No entanto cidades médias como; Uberlândia (MG), Ribeirão Preto (SP), Londrina (PR), Juiz de Fora (MG), Contagem (MG), entre outras, vêm enfrentando problemas que se acentuam a cada dia, tais como: crescimento da taxa de criminalidade; transporte público que não atende aos anseios de mobilidade da população; surgimento de transporte informal; ausência de infra-estrutura básica em bairros periféricos; favelamento; áreas centrais congestionadas e conturbadas; poluição sonora, visual e do ar; deposição irregular de entulho/lixo em lotes vagos; crescimento acelerado do comércio informal e outros, anteriormente, encontrados somente nas grandes cidades.

Em reportagem especial, a REVISTA TUDO (2001) apresentou 20 municípios em que foram considerados como lugares que se transformaram em pólos de atratividade e concentração de vários setores empresariais, onde as oportunidades de emprego aparentam ser promissoras, sendo que, entre elas, se destacam 11 cidades médias (duas capitais estaduais), com seus respectivos setores, a saber:

- Uberaba (MG): setor de indústria química, indústria de móveis e agrobusiness no total, 330 empresas;

- Juiz de Fora (MG): forte presença da indústria metal-mecânica e de informática;

- Ilhéus (BA): expansão e incentivos governamentais ao setor de informática;

- Blumenau (SC): a área de informática se expandiu, com a criação de cerca de 500 empresas de criação e adaptação de programas para computador;

- Juazeiro do Norte (CE): expressiva presença de indústrias de calçados, têxtil e de matéria-prima e equipamentos para esses setores, como máquinas de costura; - Novo Hamburgo (RS): com 985 empresas da indústria de calçados;

- Campina Grande (PB): o setor de informática conta com 57 empresas instaladas na cidade;

- Florianópolis (SC): setor de turismo em evidência; 
- Palmas (TO): a construção civil é setor mais forte. O comércio e o setor de serviços não param de crescer;

- Petrolina (PE): a agroindústria e a agricultura irrigada de frutas em expansão;

- Sobral (CE): a indústria de calçados (seis fábricas da Grendene) e a indústria de couro crescem.

No ano de 1999, o que se viu foi uma impressionante demonstração de força do interior. A agropecuária, entre todas as atividades produtivas do país, cresceu $17,8 \%$ no primeiro trimestre, em comparação com o último trimestre de 1998. A tecnologia de ponta chegou ao campo com satélites, engenharia genética e sementes transgênicas (NETO e EDWARD, 1999).

Só em Uberaba e Uberlândia, foram instalados, nos últimos anos, pelo menos, dez laboratórios avançados de estudos sobre genética do gado e produtividade de sementes. Dessa forma, somam-se a isto as atividades vinculadas ao ramo da agropecuária que apresentam alta relevância no que tange às transformações as quais várias cidades médias demonstram em seus dados.

O Instituto Alpha Assessoria e Pesquisa (NETO e EDWARD, 1999) faz, todos os anos, um levantamento sobre a capacidade de consumo dos municípios brasileiros. Ele mede o poder de compra dessas cidades de acordo com o nível de renda da população e a posse de determinados bens e serviços.

Nos últimos dezessete anos, a cidade de São Paulo perdeu um quarto de sua capacidade de compra. O Rio de Janeiro perdeu quase a metade. Nesse mesmo período, Uberlândia elevou em $21 \%$ seu potencial. Rondonópolis, em Mato Grosso, teve um crescimento de $38 \%$ em apenas doze anos, e Barretos configurou-se como um dos 100 maiores mercados do país na última pesquisa, publicada no ano de 1998. Não é por acaso que a Expozebu, a tradicional feira de 
gado de raça de Uberaba, em quase sete décadas de existência, foi visitada por mais presidentes da República do que o Salão do Automóvel, de São Paulo.

Os mesmos autores acrescentam:

Durante muitos anos, brasileiros das grandes capitais olharam para os moradores do interior de cima para baixo. Afinal, no fundo, o habitante da metrópole sempre achou que lá no interior, longe do litoral, vive uma gente provinciana, que gosta de músicas cafonas e fala dobrando os erre e comendo os esses, se alguém ainda conserva essa visão pejorativa da cidade do interior, precisa arquivá-la imediatamente. (...) O crescimento econômico de vários pólos espalhados pelo interior do Brasil nas últimas duas décadas transformou seus habitantes em personagens que exigem nova avaliação. (...) O coração econômico do Brasil hoje [começa a pulsar] mais forte em capitais regionais, distantes das metrópoles e seus problemas crônicos. (...) Nesses centros beneficiados pelo processo de enriquecimento, o brasileiro trocou a carroça pelas caminhonetes luxuosas, substituiu o chapéu de palha pelo de couro de castor e deixou de lado a calça de algodão surrado para vestir jeans importados. Hoje são eles que esnobam os urbanóides desempregados, que vivem espremidos em congestionamentos e se divertem ouvindo o quê? Música sertaneja! (NETO e EDWARD, 19.5.1999: 123).

Essas cidades apresentam índices de qualidade de vida superiores até mesmo aos de grandes cidades. Esses índices ou indicadores, de acordo com a Revista Exame (1998), são: indicadores logísticos (rodovias, ferrovias, hidrovias, aeroporto); infraestrutura (densidade demográfica, ligações de água e esgoto, área do Distrito Industrial); qualidade da mão-de-obra (número de profissionais liberais e escolas técnicas); qualidade de vida (número de leitos hospitalares, escolas de $1^{\circ}$ e $2^{\circ}$ graus, universidades, asfaltamento, transporte coletivo, programa de habitação) e políticas de incentivos.

Pode-se, também, acrescentar a esses indicadores: áreas de lazer e práticas desportivas públicas; áreas verdes (arborização das vias, parques, 
praças); ciclovias; baixos índices de criminalidade; serviços públicos eficientes (coleta de lixo - seletiva, deposição de entulhos em locais apropriados, transporte público); centros de bem-estar social de qualidade (centros de integração para idosos e adolescentes; creches, centros de reintegração ao trabalho); microbacias hidrográficas despoluídas e preservadas; áreas centrais com níveis aceitáveis de poluição sonora, visual e do ar.

No entanto cidades médias, como Uberlândia-MG, Ribeirão Preto-SP, Londrina-PR, entre outras, vêm enfrentando problemas que se acentuam a cada dia, tais como: alta taxa de criminalidade; transporte público deficiente; presença de transporte informal; ausência de infra-estrutura básica em bairros periféricos; favelamento; áreas centrais congestionadas e conturbadas; poluição sonora, visual e do ar; deposição irregular de entulho/lixo em lotes vagos; crescimento acelerado do comércio informal e outros, anteriormente, encontrados somente nas grandes cidades.

\section{5 - A cidade de Uberlândia: área urbana e o seu sistema de circulação viária}

Uberlândia caracteriza-se como uma cidade de porte médio, contando, em 2000, com uma população de 501.214 habitantes, mas pela estimativa do IBGE, a sua população para o ano de 2005 era de aproximados 585.262 habitantes. Está inserida na região do Triângulo Mineiro, porção sudoeste do estado de Minas Gerais, de posição geográfica estratégica, pois se encontra entre cinco importantes capitais: Belo Horizonte, Campo Grande, Cuiabá, Goiânia e São Paulo, além de distar $430 \mathrm{~km}$ da capital federal - Brasília. (cf. mapa 1)

Além de sua localização, a infra-estrutura viária também apresenta importância por estar servida por oito rodovias que ligam a cidade às principais capitais do país, e uma linha ferroviária da Central-Atlântica (cf. mapas 2 e 3). 
O início do povoado de Uberlândia deu-se por volta de 1818 , sendo que, em 1888, foi elevada à categoria de município. O processo acelerado de urbanização intensificou-se a partir da década de 1950, mais cedo que a realidade nacional, quando a população urbana era maior que a rural. Isso ocorreu em função da concentração de terras no município, da pouca fertilidade do solo e da pecuária extensiva, incentivando o setor comercial na cidade e assegurando uma infra-estrutura urbana que favorecesse a população residente.

$\mathrm{Na}$ década de 1940, Uberlândia registrou o incremento do setor comercial e industrial, que são aspectos marcantes da cidade, foi também nessa época que surgiu a primeira empresa imobiliária, iniciando o processo de loteamento.

Na década de 1950, com a construção de Brasília e o forte incentivo à indústria automobilística, que exigiu a construção de estradas, Uberlândia acentuou o seu crescimento e transformou-se em um entreposto rodoviário e comercial entre a região sudeste e a nova capital. 
A cidade, desde a década de 1970, é considerada como posto de distribuição de mercadorias devido à existência de várias empresas do ramo atacadista que, fundadas nas décadas de 1950 e 1960, passaram a representar em nível nacional, deixando Uberlândia conhecida como "pólo atacadista". Empresas como: Martins Comércio e Distribuição Ltda e ARCOM (Armazém do Comércio S.A.) são as que têm maior poder de mercado neste setor.

Assim sendo, a cidade, a partir dos anos 1960 e 70, consolidou-se como pólo regional, atraindo um número significativo de migrantes e, dessa forma, instituindo mudanças na dinâmica urbana do município. Estas ocorrem em função de modificações de políticas econômicas em nível nacional e outras por particularidades locais. Entre as principais, podem-se mostrar a expansão do capitalismo no campo, com a mecanização agrícola e a mudança nas relações trabalhistas, e o processo de industrialização implantado no país a partir de meados de 1950. De outro lado, destacou-se o comércio em nível regional, provendo uma intensa urbanização, como pode ser visto na tabela 10.

Tabela 10 - População residente em Uberlândia, 1950 a 1996

\begin{tabular}{r|c|c|c|c|c}
\hline \hline Ano & $\begin{array}{c}\text { População } \\
\text { Total }\end{array}$ & $\begin{array}{c}\text { População } \\
\text { Urbana }\end{array}$ & $\%$ & $\begin{array}{c}\text { População } \\
\text { Rural }\end{array}$ & $\%$ \\
\hline 1950 & 54.282 & 35.799 & 65,90 & 19.185 & 35,10 \\
\hline 1960 & 88.282 & 71.717 & 81,24 & 16.565 & 18,76 \\
\hline 1970 & 124.706 & 111.466 & 89,38 & 13.240 & 10,62 \\
\hline 1980 & 240.961 & 231.598 & 96,11 & 9.363 & 3,89 \\
\hline 1991 & 366.729 & 357.830 & 97,57 & 8.889 & 2,43 \\
\hline 1996 & 438.986 & 431.744 & 98,35 & 7.242 & 1,65 \\
\hline \hline
\end{tabular}

Fonte: IBGE, 1996.

Org: BERNARDINO, A.R., 2006

Mesmo que a cidade de Uberlândia tenha atingido a população de 500.000 habitantes, as tentativas de planejamento urbano foram poucas, recentes e resultaram apenas em planos sucessivos, sem atingir seus objetivos. 
1.5.1 - Ordenamento urbano e o sistema de trânsito e transporte em Uberlândia

A primeira tentativa de ordenamento urbano foi registrada em 1954, com o desenvolvimento do "Plano de Urbanização da Cidade de Uberlândia", elaborado pelo Departamento Geográfico do Estados de Minas Gerais. O plano aconteceu com o discurso de propor melhorias para a cidade diante dessa nova realidade, abordando os aspectos de educação, transporte, estações de trem e de ônibus.

Esse plano priorizava o sistema viário no momento em que se identificava na seguinte descrição:

...nossa atenção se voltou para o sentido do aprimoramento do centro existente, e desenvolvimento das comunicações com a área de expansão, pondo em evidência o problema viatório. (PMU, 1954, p.8).

Segundo o Censo de 1980, a população economicamente ativa concentrava $41,8 \%$ da população total, sendo que o setor primário absorvia $6,8 \%$, o secundário $28,6 \%$ e o terciário $64,6 \%$. Esses dados reafirmavam a relevância do setor terciário na economia do município. Em 1989, o comércio e serviços arrecadavam 57\% em ICM (Imposto de Circulação de Mercadorias), a indústria $38 \%$ e o setor primário com $5 \%$. Assim, Uberlândia evidenciava-se como um centro comercial expressivo, principalmente, nos setores atacadistas e varejistas, que se apresentavam diversificados.

Dessa maneira, Uberlândia acompanhou a expansão da economia local e regional, o que gerou problemas de infra-estrutura, trânsito e transporte, falta de moradias, dentre outros. 
Em 1970, já era revelada a importância que a modalidade bicicleta assumia (cf. tabela 11), e observa-se, nos planos seguintes a esse período, que essa importância tornava-se cada vez maior e, apesar das recomendações para a criação de ciclovias nos planos seguintes, somente uma ciclovia foi implantada em Uberlândia, mas esta não consta de nenhum dos planos descritos.

Tabela 11 - Composição modal do tráfego, Uberlândia, 1970

\begin{tabular}{l|c}
\hline \hline \multicolumn{1}{c|}{ MODO } & $\%$ \\
\hline Carros & 85,0 \\
\hline Ônibus & 4,5 \\
\hline Caminhão & 10,5 \\
\hline Bicicletas/Motos & 14,0 \\
\hline
\end{tabular}

Fonte: HIDROSERVICE, 1978.

Considerando tal situação, em 1978, foi que ocorreu a segunda tentativa de planejar o transporte urbano. Foi elaborado um Plano Diretor do Sistema Viário Principal pela empresa de consultoria HIDROSERVICE - Engenharia de Projetos Ltda. Esse plano continha propostas em curto prazo PAITT (Programa de Ação Imediata em Trânsito e Transporte), em médio prazo (ano horizonte 1985) e em longo prazo (ano horizonte 1995).

MESQUITA (1992) demonstra, em seu estudo, que apenas parte desse plano foi implantado, ficando restrito às alterações na geometria viária de alguns cruzamentos, à definição de mão única e a semáforos em algumas vias da área central.

Do Plano Diretor do Sistema Viário (cf. mapa 4), apenas duas medidas propostas para o ano de 1995 foram implantadas, porém em datas antecipadas, sendo dois viadutos, obras de "vulto", de impacto significativo próximos aos períodos eleitorais. 
Em 1980, a consultora HIDROSERVICE desenvolveu o "Plano de Assessoria Técnica na Implantação do Sistema de Transporte Coletivo e Plano Cicloviário de Uberlândia".

Apesar de ser um plano com base em diagnóstico bem detalhado, nenhuma dessas propostas foi implementada. O fato da não implementação vem, mais uma vez, demonstrar o descaso do órgão público responsável por esse serviço, pois o diagnóstico dexpunha a necessidade de intervenção no sistema de transporte urbano em vistas das condições precárias em que se encontrava.

É importante observar que:

...até a década de 80 não existiam em Uberlândia leis que estabelecessem normas para uso e ocupação do solo urbano. Sem o controle destas leis, a malha viária constituiu-se desordenadamente, pois não eram observados critérios inerentes à capacidade e continuidade das vias (MESQUITA, 1992. p.9).

As décadas de 1980 e 1990 foram marcadas pelo significativo crescimento populacional, concentrando na área urbana $97,5 \%$ dos seus residentes, cujo crescimento chegou a $3,9 \%$ ao ano, ocupando $4,7 \%$ da área do município (cf. tabela 12).

Tabela 12 - Área $\left(\mathrm{Km}^{2}\right)$ do município de Uberlândia, 1991

\begin{tabular}{c|c|c}
\hline \hline Tipo & Área $\left(\mathrm{Km}^{2}\right)$ & $\%$ \\
\hline Urbana & 189 & 4,7 \\
Rural & 3.851 & 95,3 \\
\hline Total & 4.040 & 100,0 \\
\hline
\end{tabular}

Fonte: Uberlândia, 1991

A importância do uso e ocupação do solo dá-se em razão da interferência direta no transporte urbano, tanto nos aspectos estruturais quanto operacionais, e se reforça quando se observa, em 1988, a área urbana de Uberlândia com cerca 
de 163.623 imóveis registrados e utilizados da seguinte forma:

Tabela 13- Destinação dos imóveis urbanos, 1989

\begin{tabular}{l|c}
\hline \multicolumn{1}{c|}{ Destinação } & Número de Imóveis \\
\hline Imóveis sem uso & 81.871 \\
Residências & 71.408 \\
Comerciais & 5.704 \\
Outros & 4.640 \\
\hline Total & 163.623 \\
\hline \hline
\end{tabular}

Fonte: FREITAS, 1989.

A realidade dos dados identifica o percentual de $50 \%$ de imóveis desocupados (cf. tabela 13) estavam sem cumprir sua função social.

A Lei Orgânica Municipal de 1990, no seu capítulo II, artigo 120, é contrariada frontalmente por esse tipo de ocupação, pois nesse artigo explicita ser finalidade da Política Municipal de Desenvolvimento Urbano "controlar o uso do solo, de modo a evitar a ociosidade ou não-ocupação do solo urbano edificável".

O acelerado crescimento urbano de Uberlândia aconteceu sem que um planejamento urbano formal tenha sido implantado onde fosse possível prever os impactos sócio-espaciais decorrentes desse processo, que, fatalmente, iriam intervir na qualidade de vida urbana.

Somente em 1989, ocorreu a criação da Lei Municipal número 5013, de 01 de dezembro de 1989, dispondo sobre o uso e a ocupação do solo, caracterizando a cidade segundo nove zonas de usos.

Essa lei municipal, número 5013, de 01 de dezembro de 1989, caracterizou a cidade em nove zonas de usos:

- predominantemente residencial, com baixa ocupação;

- predominantemente residencial, com baixíssima ocupação;

- zona mista com alta taxa de ocupação, com coeficiente de 
aproveitamento 4,0;

- zona mista com alta taxa de ocupação, com coeficiente de aproveitamento 5,0;

- predominantemente residencial, com alta taxa de ocupação;

- zona Industrial, permitindo indústria, comércio e serviço de grande porte;

- zona especial das vias arteriais, uso misto, permitindo indústria, comércio e serviços de médio porte;

- zona especial das vias arteriais - uso misto, permitindo indústrias e instituições de pequeno porte;

- zona especial das vias coletoras - uso misto, permitindo indústrias e instituições de médio porte;

- zona mista, permitindo comércio, serviços e indústrias (não poluentes) de grande porte. (Lote mínimo de $2.000 \mathrm{~m} 2$ );

- zona mista, com alta taxa de ocupação;

- zona de proteção ambiental das margens do Rio Uberabinha. Não é permitido o parcelamento. Uso residencial com baixíssima ocupação.

Importante ressaltar que, até dezembro de 1999, essa foi a lei que vigorava, pois a Lei de Uso e Ocupação do solo, que acompanhava o Plano Diretor de 1994, foi aprovada em dezembro de 1999, somente seis anos após a criação da lei que regulamenta o Plano Diretor, cujo ano horizonte de planejamento é de 15 anos. Pode-se observar no mapa 5 a representação cartográfica da parcelamento e zoneamento do uso e ocupação do solo de Uberlândia. 
Apenas a definição de uma lei de uso e ocupação do solo não caracteriza um processo de planejamento, pois, na maioria das vezes, não é respeitada e tampouco não é revisada no que diz respeito às modificações para atingir a qualidade de vida urbana. Consta-se que a concessão de ações que vão contra a lei visa favorecer a especulação imobiliária e interesses de determinados empresários dentro de um processo clientelista.

A lei de uso e ocupação do solo, de 1989, não define diretrizes, como: priorizar o adensamento das áreas vazias em detrimento de criação de novos loteamentos; a estrutura urbana em consonância com o sistema de transporte urbano, que podem contribuir para oferecer melhor qualidade de vida urbana.

Uma resultante desse não planejamento urbano é a localização da população de baixa renda em bairros periféricos, desprivilegiada de maioria das infra-estruturas e de acesso à área central, localização do maior número de empregos. Esta situação é também dificultada pela ineficiência do sistema de transporte urbano, seja na questão do custo, do tempo de deslocamento, de conforto e da confiabilidade. Resende (1982) explica bem a situação, ao afirmar que: nas cidades brasileiras, os serviços urbanos se irradiam do centro à periferia, tornando-se mais escassos à medida que a distância do centro aumenta.

Salienta que, em 19 de outubro de 2006, foi publicada a Lei Complementar $n^{\circ}$. 432, que aprova o Plano Diretor do Município de Uberlândia, a qual estabelece os princípios básicos e as diretrizes para sua implantação. A partir desta, torna-se revogada a Lei complementar $n^{\circ} .078$ de 27 de abril de 1994 (UBERLÂNDIA, 2006).

Pelas estimativas do IBGE, previa-se que, em 2006, o município de Uberlândia chegasse a 600 mil habitantes e que a população residente poderia atingir 585.262 habitantes Deve-se isto à taxa de crescimento populacional de 3,5\% ao ano, entre 2004 e 2005, em que o município ganhou cerca de 20 mil novos moradores, quer pelo número de registros de nascimentos ou pela quantidade de imigrantes que chegam ao município em busca de melhores condições de moradia, educação, assistência social, saúde, empregos, entre 
outras necessidades (MUNDIM, 2005, p.B8).

Concomitante a esse crescimento populacional, a frota de veículos automotores, cuja classificação está em terceiro lugar dentre os municípios do estado de Minas Gerais com maior número de veículos, perde somente para a capital mineira e a cidade de Contagem, o que demonstra o aumento progressivo da frota, que já chegou aos $6,3 \%$ no ano de 2005. Esta situação pode ser observada na tabela abaixo.

Tabela 14 - Evolução da frota total de veículos da cidade de Uberlândia - 2002 a junho de 2006

\begin{tabular}{c|c|c}
\hline \hline Ano & Frota de veículos & $\mathbf{\%}$ \\
\hline 2002 & 170.500 & $\ldots$ \\
\hline 2003 & 178.626 & 4,8 \\
\hline 2004 & 187.911 & 5,2 \\
\hline 2005 & 199.780 & 6,3 \\
\hline Jun2006 & $205.510^{*}$ & $2,9^{*}$ \\
\hline \hline .. dado não disponível; \\
*DENATRAN, 2006; \\
Fonte: DENATRAN, 2005 \\
Org: BERNARDINO, A. R., 2006
\end{tabular}

Com o intuito de gerir melhor o sistema de tráfego no trânsito da cidade e oferecer segurança à população, a SETTRAN utiliza-se de uma Central computadorizada do Tráfego em Áreas (CTA) para o controle nos semáforos. São mais de 160 semáforos espalhados por Uberlândia, cujo funcionamento é controlado por uma central computadorizada. O sistema, instalado na Secretaria de Trânsito e Transportes, registra os eventos, os defeitos e mostra a situação do trânsito em cada subárea da cidade, permitindo ao operador uma análise imediata da situação e definição das providências necessárias.

A CTA mostra, por exemplo, se há lâmpada queimada em algum semáforo, se falta energia na interseção ou um sinal amarelo intermitente em um determinado cruzamento. Quando um defeito é registrado pela Central, o operador aciona os técnicos de manutenção, que se dirigem imediatamente ao local. Um total de 130 cruzamentos estão interligados em rede a um computador 
e são distribuídos em subáreas, que foram definidas conforme as características do trânsito.

Para o IBGE, o índice da taxa de crescimento populacional de Uberlândia está acima do valor médio anual do Brasil, que é de 1,2\% ao ano. Se comparada a outras cidades do mesmo porte, como Londrina, Ribeirão Preto, Juiz de Fora, Contagem e Joinville, Uberlândia registra o maior índice.

A conseqüência desse fato é o desequilíbrio entre o número de empregos ofertados e a quantidade demandada, o qual requer do poder público um esforço para oferecer mais infra-estrutura, ensino básico, meios de transporte, saneamento, habitação e serviços de saúde.

Pesquisas realizadas demonstram que as cidades da região do Triângulo Mineiro e Alto Paranaíba perdem moradores para Uberlândia. De 66 cidades que estão na região, 43 reduzem ou crescem menos que a média nacional. Ituiutaba, Cachoeira Dourada, Capinópolis, Prata, Tupaciguara, Monte Alegre, Cascalho Rico são algumas cidades que sofrem o processo de emigração.

O processo de imigração em Uberlândia pode ser constatado por meio das informações que compõem o Banco de Dados Integrados (BDI) da Prefeitura Municipal de Uberlândia (PMU), em que os $16 \%$ dos procedimentos ambulatoriais do Hospital de Clínicas da Universidade Federal de Uberlândia (UFU) são realizados em pacientes residentes de outras localidades (MUNDIM, 2005, p.B8).

A cidade de Uberlândia é atrativa pelos seus 9.500 estabelecimentos, entre serviços médicos, hospitais, comunicação, transportes, alimentação, diversão e ensino, que contribuem para a expectativa dos migrantes. Em contrapartida, o último levantamento da PMU, em 2001, apontou $12 \%$ da população desempregada. 
Tendo em vista os esforços da gestão pública, foram aplicados, no ano de $2005, R \$ 800$ milhões na tentativa de expandir e criar novos negócios visando a mais empregos para os que habitam Uberlândia.

Decorrente do alto e rápido crescimento urbano de Uberlândia, estudos sobre as externalidades negativas presentes na área urbana são justificáveis na perspectiva de demonstrar e discutir como determinados fatores ou ações podem minimizar os aspectos que intervêm no desenvolvimento da cidade e de sua população, sendo um deles de importância peculiar, por se tratar de saúde pública: os acidentes de trânsito.

Um estudo realizado por Goulart e Ribeiro (1985 apud SILVEIRA, 2002) mostra como evoluíram, ao longo de 1960 e 1980, os óbitos em Uberlândia e chama a atenção para o grupo de acidentes, violências e traumatismos que, praticamente, inexistiam nos anos anteriores a 1967, passando, a partir daí, a aparecer em todos os anos e chegando ao quarto lugar entre as causas de mortalidade no ano de 1976. Considerando que esse grupo não se altera em virtude de eventuais aperfeiçoamentos diagnósticos, percebe-se a gravidade e a extensão do significado desta causa de mortalidade para a cidade.

Em pesquisa realizada no Instituto Médico Legal (IML), instalado no Hospital de Clínicas de Uberlândia, Silveira (2002) apresentou os dados e observou as informações sobre as vítimas fatais, que se envolveram em acidentes de trânsito na cidade, tais como: ocorrência com mais freqüência entre pessoas do sexo masculino, jovens e solteiros decorrentes dos acidentes com veículos quatro rodas ou mais, seguidos pelos atropelamentos. A maioria das vítimas fatais residia em Uberlândia, mas eram naturais de outros municípios. Os óbitos por acidentes de trânsito ocorrem em sua maioria aos sábados e domingos, sendo que a quase totalidade falece nas primeiras 24 horas decorridas do acidente, conseqüência de politraumatismos associados ou não a Traumatismo Crânio-encefálico. A taxa de óbitos por acidentes de trânsito para 
cada 100.000 habitantes é semelhante à de outras cidades e de todo o Brasil, e é maior nas idades mais avançada.

Segundo um levantamento feito pela Secretaria Municipal de Trânsito e Transportes (SETTRAN), $70 \%$ dos acidentes em Uberlândia ocorrem em cruzamentos com semáforo e $98 \%$ em locais com algum tipo de sinalização, o que indica um outro percentual: $90 \%$ das ocorrências acontecem em conseqüência de falhas humanas, principalmente, imprudência, seja de motoristas, motociclistas, ciclistas ou pedestres. Foram registrados 7.972 acidentes de trânsito no ano de 2004, sendo 38 com vítimas fatais (CORREIO, 2004).

Todos os estudos revelam a importância do tema sobre os acidentes de trânsito, no intuito de serem fontes de informações cabíveis junto ao desenvolvimento de políticas públicas voltadas à sua redução, tendo em vista a busca da melhoria da qualidade de vida de seus residentes. 


\section{CAPÍTULO 2}

\section{BASES FUNDAMENTAIS UTILIZADAS NA INTERPRETAÇÃO DOS DADOS SOBRE OS ACIDENTES DE TRÂNSITO EM UBERLÂNDIA}

\section{1 - A importância do geoprocessamento na interpretação dos dados sobre os acidentes de trânsito}

Sabe-se que os recursos tecnológicos, ultimamente, são utilizados como parte importante para diversos estudos nas áreas da ciência e da sociedade, que implicam distribuição geográfica. São tecnologias computacionais, que instrumentalizam os pesquisadores, o governo $e$ as instituições visando à transformação dos dados em interpretações de informações que orientem ações cabíveis.

Com o advento dos computadores e seu emprego crescente no tratamento da informação, as áreas que tinham em comum o tratamento e a utilização de informação espacial, como a Cartografia, a Geografia, o Planejamento Urbano e Regional, a Biogeografia, a Arqueologia, a Paleontologia, as Engenharias etc., cada uma com as suas necessidades, foram induzidas a constituir a melhoria de suas técnicas informáticas e do modelamento matemático, estatístico e/ou lógico, por meio do computador. Por terem em comum o processamento de informação espacial (ou geográfica) e terem apoio em computador, esse conjunto de técnicas computacionais começaram a ser nomeadas de "geoprocessamento" (JUNQUEIRA,1998).

Tais áreas temáticas tiveram várias necessidades, as quais se devem a três fatos principais:

- a necessidade moderna de uso mais racional do espaço, como um fator de produção e de vantagem competitiva. É enorme a utilidade do geoprocessamento para desvendar as potencialidades e as restrições no uso do espaço, e por serem ferramentas usadas em todas as fases de gestão do 
território, desde o planejamento, a execução, e o controle das políticas com efeitos territoriais;

- o benefício do grande desenvolvimento, conjunto das aplicações da eletrônica, das ciências da informação, da computação e da comunicação, dentro de uma sociedade que se tornou, rapidamente, uma sociedade informatizada;

- o processo de convergência tecnológica, que apresenta conceitos e meios cada vez mais eficazes para o tratamento da informação espacial para as mais diversas áreas (JUNQUEIRA, 1998).

Assim, somam-se às necessidades tais contribuições técnicas que algumas áreas de estudos construíram e fazem avançar o conhecimento no que tange à tecnologia da informação espacial (cf. quadro 1). 


\section{Quadro 1 - Contribuições para a tecnologia da informação espacial}

\begin{tabular}{|c|c|}
\hline Geografia & $\begin{array}{l}\text { oferece as metodologias de entendimento do mundo, como lugar do } \\
\text { homem, do funcionamento do espaço humanizado e do espaço físico; } \\
\text { longa tradição em análise espacial, gerando modelos lógicos que vão } \\
\text { sendo implementados pela estatística, matemática, lógica simbólica, } \\
\text { ciência da computação etc.; } \\
\text { oferece técnicas, procedimentos e metodologia quer permitem a } \\
\text { condução adequada da análise espacial e da perspectiva espacial da } \\
\text { pesquisa; } \\
\text { a relação entre a Geografia e o GIS é tão profunda, em termos } \\
\text { metodológicos, que em certo sentido, pode se considerar o GIS como } \\
\text { uma Geografia apoiada em computador. }\end{array}$ \\
\hline Cartografia & $\begin{array}{l}\text { contribui com técnicas de visualização da informação espacial; } \\
\text { atualmente, é a maior fonte de entrada de dados para o SIG, por meio } \\
\text { da compilação de mapas; } \\
\text { apresenta longa tradição na concepção de mapas, contribuindo para a } \\
\text { solução das saídas gráficas do SIG; } \\
\text { a cartografia analítica, também chamada "cartografia digital", ou } \\
\text { "cartografia automática" oferece métodos de representação digital e } \\
\text { manipulação de feições cartográficas e métodos de visualização. }\end{array}$ \\
\hline Sensoriamento Remoto & $\begin{array}{l}\text { imagens obtidas a partir do espaço e de estações orbitais, são grandes } \\
\text { fontes de dados geográficos; } \\
\text { o sensoriamento remoto inclui técnicas de aquisição e processamento } \\
\text { de dados sobre todo o Globo, a mais baixo custo e com razoável } \\
\text { capacidade de atualização; } \\
\text { muitos sistemas de processamento de imagens oferecem funções } \\
\text { analíticas sofisticadas; } \\
\text { dados interpretados por meio de sensoriamento remoto podem ser } \\
\text { agregados a outros planos de informação do SIG como dados ancilares. }\end{array}$ \\
\hline Pesquisa Operacional & $\begin{array}{l}\text { muitas aplicações de SIG requerem uso de técnicas de otimização } \\
\text { para processos de tomada de decisão; } \\
\text { o SIG especializado em planejamento do transporte (roteamento) é } \\
\text { um grande exemplo desta aplicação. }\end{array}$ \\
\hline Ciência da Computação & $\begin{array}{l}\text { os sistemas CAD (Computer-Aided-Design) promovem o } \\
\text { desenvolvimento de recursos para entrada, visualização, } \\
\text { representação e armazenamento de dados, inclusive em 3D; } \\
\text { avanços na computação gráfica oferecem soluções de hardware e de } \\
\text { software para manipulação, visualização, mensuração e transporte de } \\
\text { objetos gráficos; }\end{array}$ \\
\hline
\end{tabular}




\begin{tabular}{|c|l|}
\hline \hline $\begin{array}{c}\text { Cont. Ciência da } \\
\text { Computação }\end{array}$ & $\begin{array}{l}\text { sistemas de DBMS (Database Mangement Systems), ou SGBD } \\
\text { (Sistemas de Gerenciadores de Bancos de Dados) oferecem métodos } \\
\text { de representação de dados em forma digital, procedimentos de } \\
\text { organização e manipulação de grandes volumes de dados, } \\
\text { particularmente o acesso e a atualização; }\end{array}$ \\
$\begin{array}{l}\text { a IA (Inteligência Artificial) utiliza o computador para formular modelos } \\
\text { heurísticos, isto é, baseados na experiência humana para a } \\
\text { compreensão de fenômenos e produção de métodos de tomada de } \\
\text { decisão, por meio de "sistemas especialistas", por exemplo. }\end{array}$ \\
\hline Matemática & $\begin{array}{l}\text { muitos aspectos da teoria matemática são utilizados em benefício } \\
\text { do SIG, especialmente, a Geometria e a Teoria dos Grafos, são } \\
\text { empregadas na construção das ferramentas SIG e nos processos } \\
\text { de análise espacial. }\end{array}$ \\
\hline Urbanismo & $\begin{array}{l}\text { o SIG apresenta recursos que têm origem na tradição do traçado e } \\
\text { na análise do urbano. }\end{array}$ \\
\hline Engenharia Civil & $\begin{array}{l}\text { o SIG apresenta muitas aplicaçães que têm origem em áreas de } \\
\text { aplicação da engenharia civil, como transporte, redes de } \\
\text { infraestrutura, etc, (rede de água e esgoto, telefonia, eletricidade). }\end{array}$ \\
\hline \hline
\end{tabular}

Org: BERNARDINO, A.R., 2006

Fonte: JUNQUEIRA, 1998

A busca de recursos voltados às tecnologias computacionais, como as de coleta, tratamento e análise de informações espaciais e o uso de sistemas, servese das técnicas utilizadas no geoprocessamento, cujos interesses por objetos de expressão espacial, localização ou distribuição espacial de seus atributos são comuns.

No que se refere às tecnologias do geoprocessamento, este é aplicado por profissionais que trabalham com Processamento Digital de Imagens (PDI), Sensoriamento Remoto, Cartografia Digital e Sistema de Informação Geográfica (SIG), observando a variabilidade de seu uso nas áreas de geografia, cartografia, agronomia, geologia, engenharias, arquitetura, planejamento urbano e regional, além de outras áreas afins.

Para Rosa e Brito (1996), o geoprocessamento define-se como o conjunto de tecnologias destinadas à coleta e aotratamento das informações espaciais, assim como ao desenvolvimento de novos sistemas e aplicações, com diferentes níveis de sofisticação. 
Felgueiras (1990) apresenta a sua definição, indicando que o geoprocessamento é uma ferramenta potencial e essencial para agilização e automação de diversas tarefas relacionadas a informações geográficas, permitindo a realização de atividades de planejamento e gestão nas mais diversas áreas do conhecimento humano.

Para Rodrigues (1989), o geoprocessamento é um conjunto de tecnologias de coleta e tratamento de informações espaciais e o desenvolvimento e uso de sistemas de que se servem. Os procedimentos de coleta, tratamento e utilização de informações espaciais têm tido desenvolvimento próprio, adequando-se às necessidades específicas de cada área.

Rosa et al. (2005), em suas discussões, defendem que as técnicas de geoprocessamento flexibilizam e agilizam os trabalhos, melhorando a interpretação de informações por meio da combinação de diferentes mapas temáticos, e tornam a Cartografia Digital um método eficaz de auxílio na interpretação de fenômenos espaciais, principalmente se tratando do espaço urbano.

O objetivo do uso da cartografia digital no processo de planejamento urbano é o de auxiliar quanto à organização e à estruturação das informações, oferecendo suporte nas tomadas de decisões, a fim de garantir o desenvolvimento harmônico em todos os setores, buscando atingir a qualidade de vida urbana desejada pelos citadinos.

Francisco Filho (2004) acrescenta que o geoprocessamento é uma ferramenta valorosa na análise dos fenômenos com expressão territorial, pois, permite a espacialização por meio da quantificação, qualificação e localização, assim como o relacionamento com outras variáveis espaciais.

A espacialização das informações indica um caminho orientado para muitas das ações prioritárias durante uma gestão administrativa pública, que os 
dirigentes precisam observar, para subsidiar suas decisões com confiabilidade e segurança, quer seja no planejamento urbano ou em qualquer outra temática da gestão urbana.

Assim, é de grande importância o conhecimento da distribuição espacial das informações disponíveis nos bancos de dados, resultando em mapeamentos, em que, de forma clara, a apresentação da espacialização esteja direcionada para a localização, a quantificação e o relacionamento com os elementos e equipamentos que fazem parte da dinâmica urbana.

Nota-se que o impulso das técnicas computacionais facilitou a utilização de mapas em maior escala com o desenvolvimento de muitos trabalhos, sem que houvesse grandes obstáculos, quando no processo de espacialização de informações, uma vez que tais técnicas propiciam as consultas e a localização das informações através de "software's" próprios para determinadas funções.

Oliveira (1993) esclarece que a principal questão está no aspecto da informação adequada, porém pode-se caracterizar a sua insuficiência e a sua baixa qualidade como circunstância comum nas administrações públicas, principalmente em cidades de pequeno e médio portes, onde existem muitas informações do tipo inconsistentes e poucas informações adequadas. Estas ficam dispersas dentro do órgão gerenciador, o que exige grandes esforços para localizá-las e integrá-las. Muitas vezes, as informações são retidas, ou ainda, aquelas importantes, geralmente, chegam após a tomada de decisão ou não são confiáveis.

É preciso atentar para alguns indicadores de que o DENATRAN (2006a) dispõe, como os problemas de certificação durante o levantamento de dados dos acidentes de trânsito, como, por exemplo:

- número de condutores envolvidos em acidentes de trânsito menor que o número de acidentes de trânsito: em cada acidentes de trânsito 
é necessário que haja, pelo menos, um condutor de veículo envolvido; portanto, o número de condutores não pode ser menor que o número de acidentes. Esse é um erro comum no preenchimento das planilhas;

- número de veículos envolvidos em acidentes de trânsito menor que o número de acidentes: em cada acidentes de trânsito, é necessário que haja pelo menos um veículo, portanto, o número de veículos tem que ser maior ou igual ao número de acidentes;

- número de vítimas menor que o número de acidentes: só estão sendo levantados acidentes de trânsito com vítimas, portanto, o número de vitimas só pode ser maior ou igual ao número de acidentes.

- número de veículos envolvidos em acidentes de trânsito menor que o número de condutores de veículos acidentados: é possível haver mais veículos que o número de condutores acidentados, como seria o caso de um veículo em movimento bater em dois veículos estacionados; entretanto não é possível haver mais condutores que o número de veículos acidentados, porque a cada condutor deve corresponder pelo menos um veículo acidentado.

Ao considerar a base de dados e os recursos envolvidos no processo de tomada de decisões torna-se importante conhecer o nível da qualidade dos componentes que formam um sistema de informação geográfica, pois são eles que irão ofertar a confiabilidade ao sistema e, logo, nos resultados.

Observa-se, assim, que é a informação a base de todo o processo, sendo, portanto, necessário que se saiba como captá-la, depurá-la, organizá-la, armazená-la, controlá-la, analisá-la e divulgá-la, formando-se, então, um sistema de gerenciamento da informação. 
Dessa forma, considera-se a cartografia favorecida pelos recursos da informática, um tipo de sistema de informação que apóia a apresentação espacializada dos dados geográficos informatizados, de forma a assegurar que as interpretações e análises alcancem melhores níveis de confiabilidade no que se refere ao planejamento, monitoramento e tomada de decisões relativas ao espaço geográfico.

\section{2 - Subsídios conceituais para análise dos dados e informações sobre os acidentes de trânsito}

Os acidentes de trânsito possuem diferentes características em cada país ou região, porém, um único fator é comum a todos os casos, o impacto causado pelo uso do automóvel. Assim, definições importantes sobre os acidentes de trânsito para a análise e o tratamento dos dados serão apresentados, bem como o seu próprio conceito.

Torna-se essencial o conhecimento das causas dos acidentes como um dos requisitos para sustentar medidas que diminuam sua incidência. Isto requer informações sobre os tipos de acidentes que ocorrem em um determinado local, além de visitas técnicas no dia e hora de maior freqüência de acidentes.

Para Gadret (1969) o trânsito significa a função da via, o emprego que dela fazem os veículos e pedestres, enquanto o tráfego corresponderia à atividade, ao movimento conjunto dos veículos na via pública.

Seguem algumas definições básicas, utilizadas por Gold (1998), consideradas importantes quando no tratamento e na análise dos dados obtidos sobre os acidentes de trânsito. 
A OMS define acidente como um evento independente do desejo do homem, causado por força externa, alheia, que atua subitamente e deixa ferimento no corpo e na mente.

Gold (1998) apresenta, assim, o conceito de acidente de trânsito como um evento do tipo descrito, que envolve ao menos um veículo que circula, normalmente, por uma via para trânsito de veículos, podendo ser o veículo motorizado ou não. Outra definição simples, também estaria caracterizada por um evento não intencional que produz ferimentos ou danos.

Os acidentes sem vítimas são aqueles que produzem danos materiais, que não resultem pessoas feridas entre os envolvidos no evento. Atenta-se que muitos dos acidentes sem vítimas não o são na realidade, por haver lesões internas que passam despercebidas no momento da confecção do boletim de ocorrência, mas manifestam-se posteriormente, às vezes, até mesmo causando a morte.

Trata-se dos acidentes com vítimas aqueles resultantes de ferimentos em menor ou maior grau, em, pelo menos, uma das pessoas envolvidas. Em tais acidentes, os ferimentos são classificados como leves ou graves, porém a classificação leves nos Boletins de Ocorrência (B.O.) podem ser, na realidade, acidentes que tenham vítimas com ferimentos graves, da mesma forma que o acidente com vítimas pode ser classificado como sem vítimas, pois não há um diagnóstico médico prévio. São informações dos agentes de trânsito ou da polícia militar, responsáveis pelo registro da ocorrência.

Por outro lado, um ferimento classificado como grave pode ser, realmente, um ferimento leve, como, por exemplo, uma hemorragia forte que se deve apenas a ferimentos superficiais do couro cabeludo.

O acidente fatal refere-se aos acidentes de trânsito com resultado de morte de, pelo menos, uma das vítimas. Sabe-se que alguns acidentes registrados nos 
B.O. como acidente com vítimas são, na realidade, fatais devido ao falecimento posterior à data do evento, ocorridos nos hospitais e nas clinicas médicas, mesmo que meses depois do acidente.

Quanto à distribuição geográfica, observa-se a expressividade nos acidentes de trânsito ocorridos na área central e fora da área central, nas interseções ao longo da via, no entorno dos pólos geradores de tráfego e nos pontos críticos.

$\mathrm{Na}$ área central, há uma concentração de acidentes de trânsito, pois ali se localiza a maior parte das atividades de comércio e serviços. Por isso, não se pode estimar que as condições de trânsito na área central sejam mais perigosas que no resto da cidade, uma vez que a concentração reflete os volumes relativamente altos de fluxo de veículos e pedestres nesse espaço.

$\mathrm{Na}$ interseção de duas ou mais vias, local que, naturalmente, apresenta uma alta freqüência de acidentes, ocorrem, vez por outra, movimentos conflitantes entre os veículos e entre veículos e pedestres.

Os pólos geradores, independentemente de sua localização na área central, nas interseções ao longo da via, incluem supermercados, centros comerciais, terminais de transportes coletivos, pontos de paradas de ônibus e escolas. Esses pólos tendem a ser locais de acidentes, principalmente se não são adotadas disposições para minimizar os riscos.

Quanto à distribuição temporal dos acidentes, os dados, por dia de semana e por hora do dia, oferecem condições em que se destacam as características particulares dos atropelamentos e dos acidentes de veiculares, com ou sem vítimas, como, por exemplo:

- nas horas de maior fluxo de veículos e de pedestres, é normal que ocorram mais atropelamentos; 
- nas horas de baixo fluxo de veículos proporcionam velocidades mais altas, o que aumenta o risco de vítimas com maior gravidade;

- nas noites de sextas-feiras, sábados e domingos, é maior o consumo de bebidas alcoólicas, além da diversão do final de semana deixar os condutores e pedestres mais cansados no dia seguinte; e

- durante os fins de semana, há mais pessoas sem experiência nas vias conduzindo os veículos, comumente conhecidos como "os domingueiros".

Referindo-se aos tipos de acidentes, o atropelamento é o acidente em que um pedestre ou um animal é atingido por um veículo - motorizado ou nãomotorizado -, podendo ocorrer na pista ou na calçada, estando em movimento ou parado.

Quando ocorre a colisão, o acidente envolve dois ou mais veículos em movimento, no mesmo sentido ou em sentido oposto, na mesma faixa da via. Este tipo de acidente subdivide-se em colisão frontal e traseira. A primeira é a colisão em que dois veículos em movimento, em sentidos opostos, colidem. E a colisão traseira é a que ocorre entre dois veículos em movimento, no mesmo sentido. O engavetamento é o que ocorre também na mesma faixa da via com três ou mais veículos, ou por colisão traseira ou frontal.

O abalroamento lateral é o acidente entre veículos em movimento em faixas distintas, porém, no mesmo sentido, quando um deles inicia uma conversão à esquerda ou à direita.

O abalroamento transversal envolve veículos que em um ângulo de $90^{\circ}$ um em relação ao outro, colidem, geralmente, em interseções, saídas de estacionamento, etc.

Ocorre, ainda, o abalroamento transversal frontal, quando o ponto de colisão entre ambos os veículos é a parte dianteira, e o abalroamento lateral em sentidos 
opostos é o acidente entre veículos que estão em sentidos opostos e em faixas distintas. É comum, neste caso, que um dos veículos esteja iniciando uma conversão à esquerda ou à direita.

Outro tipo de acidente é o choque, em que o veículo colide com um obstáculo sem movimento, que pode ser um outro veículo parado ou um obstáculo físico. Em geral, os obstáculos fixos encontram-se fora da área de circulação, como: equipamentos de sinalização, postes de iluminação, árvores, bancas de jornais, caixas de correio, defensas e gradis.

A capotagem é qualquer acidente em que o teto do veículo toma contato como o chão, pelo menos, uma vez durante o acidente.

O tombamento é quando ocorre o acidente envolvendo um só veículo, em que um dos lados do veículo fica em contato com o chão, ao final do acidente.

Acrescenta-se, nesta lista, a combinação, podendo ocorrer acidentes em que dois ou mais tipos desses farão compor o evento em fase de registro.

Todos esses conceitos darão suporte às análises dos dados sobre os acidentes de trânsito, bem como nas correlações deles com fatores externos que interferem, direta ou indiretamente, nos resultados, além de subsidiar as considerações acerca da temática.

A esses conceitos que subsidiam as análises dos acidentes de trânsito, acrescem-se outras informações de cunho importante, que, em geral, são extraídas dos B.O. dos acidentes de trânsito (BRASIL, 2002):

- hora, data e dia da semana;

- condição do tempo; 
- tipo de acidente;

- severidade do acidente;

- movimentação dos envolvidos, incluindo pedestres, se for o caso;

- caracterização dos veículos (tipo, estado dos pneus e outros);

- condições do pavimento (seco/molhado);

- sexo, idade e estado (suspeita de ingestão de álcool e/ou drogas) dos envolvidos;

- descrição do acidente;

- croqui do acidente;

- número de identificação do documento-fonte.

Tais informações são necessárias, quando a finalidade é a identificação de locais das ocorrências de acidentes de trânsito estabelecidas para um período de análise.

2.3 - A base de dados utilizados na interpretação das informações sobre os acidentes de trânsito

Os dados utilizados neste trabalho foram os secundários, obtidos por intermédio da SETTRAN, cujas atividades de coleta, tabulações e leituras das informações dos B.O., preenchidos pelos policiais militares de Uberlândia dos $17^{\circ}$. e $32^{\circ}$. Batalhões de Polícia Militar e pelos Agentes de Trânsito do Departamento de Operações de Trânsito (DOT) da SETTRAN, que na transcrição para as planilhas (cf. anexo 1), ficaram sob responsabilidade da VERTRAN Gerenciamento e Controle de Tráfego, empresa prestadora de serviços da Secretaria Municipal. Os dados foram digitados em tabelas elaboradas por meio 
do software Access, que foi a base de arquivos eletrônicos disponibilizados no ensejo de alcançar as informações para a realização deste estudo.

Para os períodos selecionados, de 2000 a 2004, os registros extraídos dos B.O. foram tabulados utilizando dois modelos de planilhas, diferentes em alguns itens, pois sofreram alterações, dada a necessidade de melhorá-las, no que se refere ao detalhamento da tabulação dos dados primários. Um modelo foi usado para os anos de 2000 a 2003, e outro, para o ano de 2004. Deve-se essa alteração, pela SETTRAN, em suas revisões sobre os dados obtidos, que verificou a necessidade desta. Pela sua importância, uma das variáveis que sofreram alterações em seus atributos foi escolhida para as análises, a saber; "causa presumível do acidente".

A planilha utilizada no período de 2000 a 2003, em relação à do ano de 2004, passou por modificações nos seguintes itens: houve a exclusão das variáveis, condições presumíveis do veículo e movimentos dos veículos. $\mathrm{Na}$ planilha de 2004, os seguintes itens foram incluídos; placa veículo, tipo de socorro e atividade profissional dos condutores, que pode ser conferida no anexo 1. Já para o item, causa presumível do acidente, outros subitens foram acrescidos, 0 que repercutiu no rompimento dos dados do ano de 2004 em relação ao período de 2000 a 2003.

Esse procedimento fez com que, na comparação entre os dados, a representação gráfica dos atributos, por exemplo, da variável "causa presumível do acidente", não pode agrupar, num só gráfico, o conjunto dos atributos para todos os anos. A opção ocorrida foi a separação dos dados do ano de 2004 em gráfico individual.

Sabe-se que a planilha utilizada para a tabulação dos dados dos anos de 2005 e 2006 já se encontra com outras características. 
O elevado número dos registros de acidentes de trânsito, ao serem transferidos para arquivos eletrônicos facilitaram a seleção, cruzamento e análise, assim como a sua espacialização.

De posse dos dados disponíveis relativos ao período de 2000 a 2004, a seleção destes para o cruzamento das informações foi direcionada para o conhecimento das características dos acidentes de trânsito, usando as variáveis: tipo de veículos envolvidos nos eventos, condições da via e características da via. Para a variável causa dos acidentes, escolheu-se: causa presumível do acidente; para o perfil do condutor, idade, sexo e tempo de habilitação; além da distribuição temporal, com as variáveis: hora, dia, mês e ano; e, para complementar, a distribuição espacial por meio do mapeamento das vias, dos trechos e dos cruzamentos ocorrentes de acidentes de trânsito na área urbana da cidade de Uberlândia.

Importante resgatar a consideração de Oliveira (1993), quando discute a questão da insuficiência ou baixa qualidade dos dados públicos disponíveis, uma vez que, durante a análise dos dados, se deparou com uma diferença na base de dados do ano de 2001. Buscando respostas para essa inesperada situação, soube-se que, quando na coleta de dados dos Batalhões da Polícia Militar para o ano de 2001, um dos batalhões ficaram sem tabulação dos dados, ficando essa base (o ano de 2001) com lacunas variadas, quando das suas interpretações.

Acrescenta-se, também, que, referente aos dados não apurados (NA) apresentados nos gráficos, esta condição foi considerada durante a tabulação dos dados, pois em vários B.O., itens ficam sem preenchimentos devido à impossibilidade de obter a informação in locu, cuja justificada para a questão, em sua maioria, é a evasão do condutor do local do acidente, ou falta da informação por outros motivos. Além disso, os B.O. da Polícia Militar diferencia-se daquele 
preenchido pelos Agentes de Trânsito da SETTRAN (cf. anexo 2) consistindo em, mais dados não preenchidos que somam aos não apurados (NA).

\section{4 - A identificação dos pontos críticos}

Qualquer um dos programas de segurança no trânsito constará de estudos sobre as estatísticas dos acidentes de trânsito, que são extremamente necessárias ao planejamento de medidas de redução do número de ocorrências. As técnicas de identificação e tratamento de pontos críticos utilizam-se largamente de estatísticas, uma vez que seu pressuposto básico é o tratamento de locais com freqüência de acidentes acima do nível normal para uma determinada região (HALL apud PIETRÂNTONIO, 1992).

Em 2002, foi elaborado um manual de modo a constituir um guia simples e prático para o tratamento dos pontos críticos, na intenção de que todos os municípios integrados ao Sistema Nacional de Trânsito fossem capazes de utilizálo, além de estender seu uso aos DETRAN's e outros órgãos que desenvolvem ações de engenharias aplicadas em áreas urbanas.

Esse manual constitui um componente estratégico do Programa de Redução de Acidentes - PARE -, de iniciativa do Ministério dos Transportes, instituído em 1993, que tem o objetivo de combater os altos índices de acidentes de trânsito e cuja base é o resgate da postura de cidadania no trânsito, utilizando-se de alternativas que mudem o comportamento dos indivíduos, resultando em uma convivência harmônica, preventiva e defensiva no cotidiano das ruas e estradas. Acrescenta-se que, entre um conjunto com ações integradas, propõe e implementa o Projeto de Capacitação de Equipes de Órgãos Locais, com a finalidade de preparar os técnicos municipais para o tratamento adequado dos locais onde ocorrem os acidentes de trânsito. 
O Ministério dos Transportes/UnB (BRASIL, 2002) denomina como os pontos críticos aqueles da malha viária, que, em comparação com um critério estabelecido, apresentam padrões de acidentes iguais ou superiores à referência indicada. Acrescenta-se que não existe uma definição absoluta do tipo: um ponto crítico é um local com mais de $n$ acidentes por ano.

Torna-se sensato que haja uma política de tratamento dos pontos críticos com freqüência superior a 50 acidentes por ano nas capitais dos Estados brasileiros, ainda que, nas cidades de pequeno e médio porte, seja difícil encontrar um local que apresente uma freqüência tão elevada. Mesmo assim, cada cidade tem seus pontos críticos (GOLD, 1998).

No Programa PARE (BRASIL, 2002), a metodologia para o tratamento de locais críticos está baseada (cf. figura 1), em três módulos; identificação dos locais críticos, investigação dos fatores contribuintes dos acidentes e o tratamento do local crítico, além de, em cada um desses, conter subitens que interajam, mas também possuam características próprias.

A etapa da identificação de locais críticos, apresentada no módulo I, constitui-se de fundamental importância e deve ser realizada explorando os dados disponíveis sobre acidentes de trânsito. 
Figura 1 - Fluxograma dos Procedimentos no Tratamento de Pontos Críticos
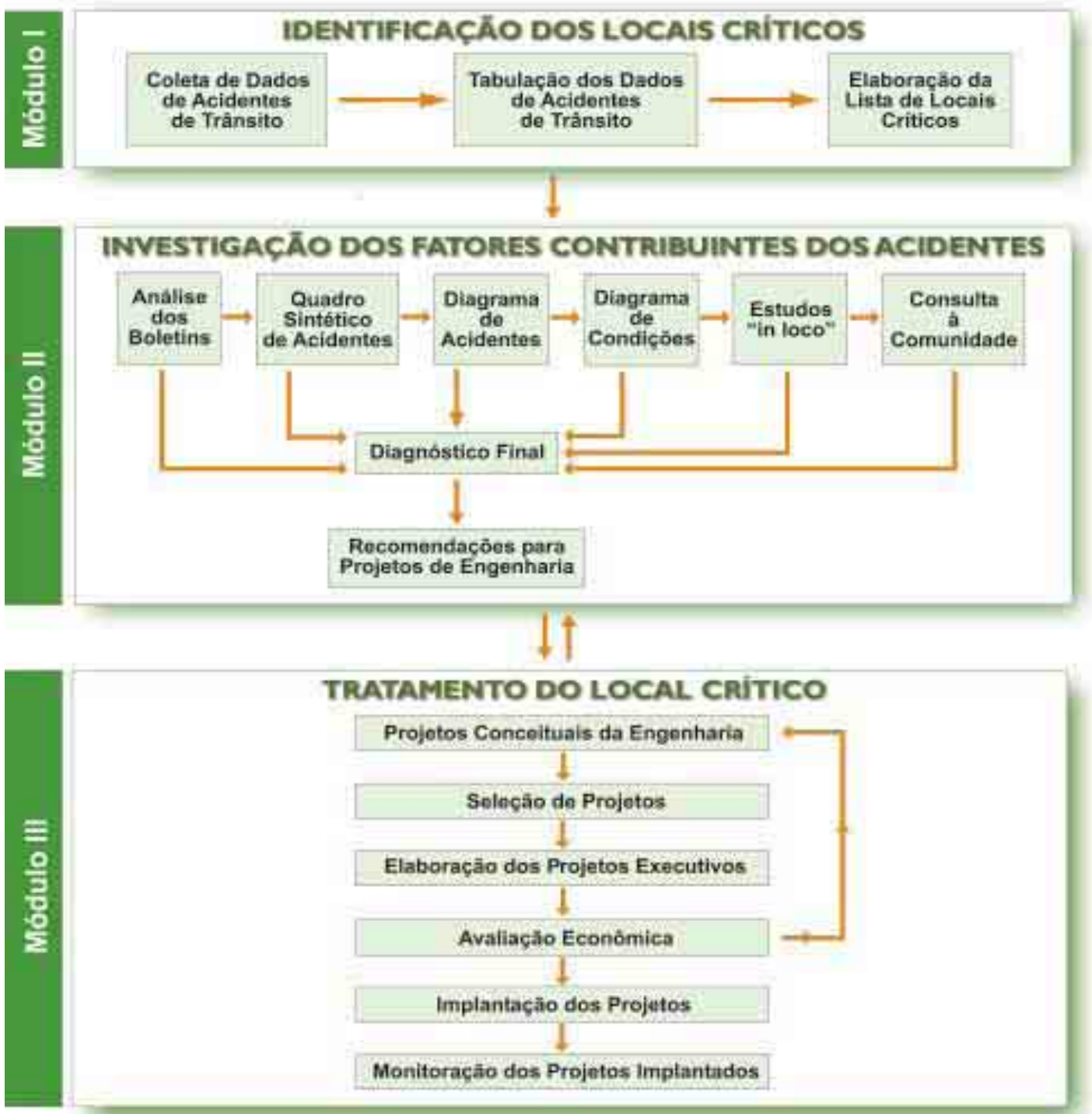

Fonte: BRASIL, 2002. p.14

Para os procedimentos desta etapa, são necessárias a qualidade do registro e a disponibilidade dos dados sobre os acidentes de trânsito. Uma vez que não há conduta comum quanto às formas de registro, na maioria das cidades, o registro e a coleta de informações são realizados por policiais militares ou civis em duas situações distintas: 
- quando o atendimento é feito no local do acidente, em caso de óbito ou feridos, ou quando há envolvimento de veículos oficiais, as informações são consignadas por policiais militares em um documento chamado Boletim de Ocorrência, comumente conhecido por B.O.;

- quando não há atendimento no local do acidente, as partes interessadas registram a ocorrência nas delegacias especializadas, sendo este documento conhecido como Registro de Ocorrência (R.O.).

De acordo com o Programa PARE, em geral, nos B.O., estão contidas informações como: local, data e horário da ocorrência, condutores, pedestres e veículos envolvidos, tipo de colisão, vítimas existentes, condições do tempo e do pavimento, extensão de danos materiais, forma de controle de trafego no local, referências ao estado dos pneus, marcas no pavimento, condição das pessoas envolvidas (portadores de necessidades especiais, sob efeito de drogas e/ou álcool) e diagrama do acidentes, as quais terão uma variabilidade de cidade para cidade.

Conforme Mello Jorge e Koizumi (2006), o Boletim de Ocorrência corresponde a instrumento utilizado nas Delegacias de Polícia, é complementado por outros registros feitos em diferentes níveis de governo, ex: Boletim do DENATRAN, ou pela Polícia Militar. Não existe padronização desses documentos, sendo que as informações coletadas, também, não são homogêneas. $O$ direcionamento da informação é variável e não há sistema algum organizado nacionalmente.

Porém, sabe-se que, durante o processo de identificação dos pontos críticos específicos, hão de existir lacunas referentes às informações procedentes das fontes utilizadas. Gold (1998) cita alguns casos mais comuns: 
- quando há vítimas, o preenchimento do B.O. não é a prioridade do policial que chega ao local. A tarefa mais urgente é auxiliar as vítimas e levá-las até o pronto-socorro mais próximo;

- nos acidentes sem vítimas e atropelamentos, ao chegar ao local ocorrido, a polícia, frequentemente, não encontra nenhum sinal do acidente, mesmo que tenham passado poucos minutos do evento. É provável que as partes tenham entrado em acordo e deixado o local;

- em casos de atropelamentos, em geral, o próprio atropelador leva a vítima imediatamente ao pronto-socorro mais próximo.

As lacunas de informações nos B.O., também, podem se originar do próprio procedimento de preenchimento. Nos casos sem vítimas, os envolvidos e as testemunhas, às vezes, retiram os veículos da via de rolamento para evitar outros acidentes ou congestionamentos, dificultando o trabalho da polícia na reconstituição da cena do acidente.

Em estudos realizados na cidade de Londrina (PR) constatou-se que as fontes policiais conseguiram captar apenas pouco mais de $32 \%$ do total de acidentes referidos por outras fontes. Quando a comparação foi feita com vítimas internadas, essa proporção elevou-se para 50\%. O número de feridos e de mortos não coincidiu com os levantamentos de outras fontes, pois seus valores referiramse somente aos indivíduos que se encontravam nessas condições no momento e local do evento. Essa pode ser apontada como uma das razões pelas quais se verifica a subestimação na mortalidade quando a fonte é o B.O.

Nas três últimas décadas, experiências nacionais no tratamento dos locais de acidente de trânsito seguem cinco linhas de atuação, a saber: por local crítico, por seguimento crítico, por área crítica, por solução-tipo e por tipo de usuário (BRASIL, 2002). 
As três primeiras permitem observar suas diferenciações no que se refere à extensão da área a ser tratada, apesar de cada uma guardar certas características, enquanto as demais apresentam identidades próprias.

O local crítico de acidente de trânsito significa uma interseção ou trecho entre interseções consecutivas que registra uma freqüência de acidentes excepcionalmente elevada, se comparada com as demais interseções ou trechos entre interseções da malha viária.

Os segmentos críticos ou rotas críticas são extensões de vias urbanas ou de rodovias onde se observam freqüências elevadas de acidentes. Neste caso, cada segmento viário deve ser tratado em sua totalidade, incluindo, às vezes, as áreas adjacentes.

$\mathrm{Na}$ análise e atuação por área crítica, em geral, observa-se que existe uma concentração de acidentes de trânsito em certas manchas urbanas onde se localiza a maior parte das atividades de comércio e de serviço, não implicando, assim, que as condições de trânsito, nessas áreas, sejam relativamente mais perigosas que noutros locais da cidade.

As estratégias que adotaram a solução-tipo tinham como característica a aplicação de determinadas medidas de engenharia de tráfego demonstraram eficácia comprovada, ou seja, que proporcionam significativa redução no número e/ou na gravidade dos acidentes. Para um determinado tipo de solução, procuram-se na rede viária, locais cujas características físicas e operacionais se enquadrem no cenário da solução-tipo e, dessa forma, possam proporcionar condições satisfatórias em relação ao alcançado em outras aplicações.

Quanto à atuação por tipo de usuário, as medidas preventivas e corretivas concentram-se num único usuário da via. Assim, os estudos podem ser dirigidos por modalidade de meios de deslocamentos como: ciclista, motociclista, escolares, pedestres, entre outros. A adoção dessa estratégia, em geral, está 
associada a políticas públicas em favor da segurança de determinada categoria de usuários do sistema viário, em vista da ocorrência de um nível elevado de acidentes envolvendo esses usuários.

Neste estudo, considerou-se a atuação em local e segmento críticos, dentre o conjunto de linhas de atuação utilizadas em experiências nacionais, apresentando as vias ou segmentos, os trechos entre as suas interseções e os cruzamentos ou pontos do sistema viário e espacializando aqueles de maiores número de acidentes de trânsito comparados aos demais ocorridos na área urbana da cidade de Uberlândia, para os anos de 2000 a 2004.

Salienta-se que os dados dos acidentes de trânsito disponíveis pela SETTRAN, referentes aos números mais altos de UPS, também foram usados com a finalidade de espacializá-los, identificando as vias ou segmentos criticos, os trechos críticos e os cruzamentos ou pontos críticos, apresentando-os quanto à severidade de todos os tipos de acidentes de trânsito ocorridos na rede de circulação viária da área urbana de Uberlândia.

Observou-se, em experiências relevantes, a adoção dessa estratégia em áreas urbanas, como o Programa de Segurança Viária e de Trânsito da Cidade de Curitiba/PR, que foi implementado no período de 1998 e 1999 pela administração municipal. Esse programa foi constituído por quatro ações básicas, que se complementavam:

1) seleção e tratamento de locais críticos de acidentes na área urbana;

2) criação de um cadastro geo-referenciado de dados de acidentes de trânsito;

3) desenvolvimento de novos procedimentos para operação do trânsito, e;

4) estudos para o fortalecimento do órgão gestor do trânsito. 
Segundo Góes (1983 apud BRASIL, 2002), os métodos de identificação mais empregados baseiam-se no fato de que os acidentes, apesar de sua ampla distribuição espacial, tendem a agregar-se em determinados locais da malha viária, os quais se classificam em três categorias: numérico, estatístico e de técnica de conflitos.

Os métodos numéricos são os mais simples e identificam os locais críticos com base no cálculo de indicadores (quantidade de acidentes, taxas de acidentes), os quais são comparados com um valor previamente estabelecido pela equipe técnica. Como locais críticos, serão declarados aqueles cujos indicadores calculados sejam maiores que esse valor.

O método estatístico envolve a utilização de modelos matemáticos probabilísticos, que determinam os locais onde o risco de acidente é superior ao estimado ou esperado.

O método de conflitos não requer levantamentos estatísticos de acidentes, mas considera que existe uma relação direta entre acidentes e conflitos de trânsito e que ações para a redução de conflitos trazem como conseqüência a redução dos acidentes.

Face ao fato de o método estatístico produzir resultados mais confiáveis, denota-se o motivo de sua escolha pelos países com maior tradição de pesquisa e que possuem disponibilidade de recursos humanos e financeiros.

Considerando a praticidade e a melhor adequação à realidade de Uberlândia, assim como os dados disponibilizados, o método numérico foi o escolhido por ser detalhado no manual do Programa PARE e foi o utilizado neste estudo. 
Fazem parte do método numérico quatro técnicas que o integram, porém discutiremos e utilizaremos duas delas: a técnica do número de acidentes e a técnica da severidade de acidentes.

A técnica do número de acidentes considera o número de ocorrências em uma interseção ou trecho entre interseções consecutivas, em um período de tempo estabelecido, definindo-se como locais críticos aqueles com quantidade de acidentes superior à média aritmética das ocorrências registradas em cada um dos locais em análise. O método tem como vantagem sua praticidade e seu baixo custo de execução, pois direciona a identificação dos locais críticos para interseções e trechos com grande número de acidentes e elevados volumes de tráfego, sendo esta a opção utilizada para apresentar os resultados.

A técnica da severidade de acidentes é um aprimoramento da anterior, em que se considera o número de ocorrências e se destaca a gravidade dos acidentes, associando a cada situação (com vítima fatal, atropelamento, com ferido e com danos materiais) um determinado peso. Estes pesos foram estabelecidos mediante a relação entre os custos atribuídos a cada tipo de severidade. Para a sociedade, um acidente com vítima fatal implica custo econômico superior a um acidente com ferido, que, por sua vez, possui custo superior àqueles somente com danos materiais.

Para complementar essa técnica, o DENATRAN (1987 apud BRASIL, 2002) instituiu a Unidade Padrão de Severidade (UPS), cujo valor, expresso em UPS, é resultante da soma dos produtos do número de ocorrências por severidade pelo peso atribuído à respectiva severidade. Assim, a quantificação dos acidentes, em UPS utilizadas nas tabelas do banco de dados da SETTRAN, foi como a seguir:

Número de UPS $=\quad$ Acidentes somente com danos materiais $\times 1$

Acidentes com feridos $x 4$

Acidentes com feridos envolvendo pedestres $x 7$

Acidentes com vítima fatal x 11 
Sendo que os pesos 1, 4, 7 e 11 são atribuídos, respectivamente, aos acidentes somente com danos materiais, acidentes com ferido(s), acidentes com feridos envolvendo pedestres e acidentes com vítima(s) fatal(is).

Os dados de números de UPS em acidentes de trânsito constantes na base de dados utilizada apresentam o número de UPS referentes a cada via, a cada trecho e a cada cruzamento, seguindo as atribuições orientadas pelo DENATRAN. Os números de UPS são relativos à soma de todas as severidades dos acidentes que ocorreram para cada um dos segmentos.

Assim, utilizou-se esse número para hierarquizar as vinte vias, os vinte trechos e os vinte cruzamentos para cada ano. A partir deste agrupamento, tirouse a média aritmética, em que se obtiveram os segmentos críticos, ou melhor, as vias críticas, os trechos críticos e os cruzamentos críticos.

Essa técnica da severidade dos acidentes tem as mesmas vantagens da técnica do número de acidentes, com o adicional de priorizar aqueles pontos ou segmentos cujos resultados apresentam maior gravidade em termos de vítimas.

É importante que se recorra, também aos números de UPS para acrescentar as informações de severidades às dos números absolutos de acidentes de trânsito, visando a uma melhor confiabilidade na identificação dos segmentos, trechos e pontos críticos. 


\section{CAPÍTULO 3}

\section{OS ACIDENTES DE TRÂNSITO OCORRIDOS NA ÁREA URBANA DE UBERLÂNDIA, 2000 a 2004: ESPACIALIZACÃO DOS DADOS E IDENTIFICAÇÃO DAS VIAS, TRECHOS E PONTOS CRÍTICOS}

\section{1 - As características, causas, o perfil dos condutores e a distribuição temporal dos acidentes de trânsito}

Para analisar a distribuição dos acidentes de trânsito ocorridos na área urbana de Uberlândia, no período de 2000 a 2004, conhecer as suas características, suas causas, perfil do condutor, bem como suas relações com o tempo e horário, escolheram-se algumas variáveis constantes nas planilhas de levantamento de dados de acidentes de trânsito, as quais se utilizaram da técnica do agrupamento dos dados disponíveis, e assim, da seleção de intervalos de classes visando às posteriores análises, a saber:

- referentes às características dos acidentes, foram selecionadas as variáveis: tipos de veículos, condições e características das vias, para todos os anos;

- para as causas dos acidentes, escolheu-se a variável causas presumíveis dos acidentes, em que se fez o cruzamento dos dados relacionados com a severidade;

- para conhecer o perfil dos condutores de veículos envolvidos em acidentes de trânsito, foram selecionadas variáveis que indicaram a idade, o sexo e o tempo de habilitação relacionado com a severidade dos acidentes;

- para a distribuição temporal dos acidentes registrados, foram consideradas todas as faixas por horários, os dias da semana, os meses do ano, além dos 
anos selecionados para o estudo, os quais serviram de base para todas as representações gráficas, a fim de realizar a análise comparativa da evolução ano a ano;

A exposição dos resultados, serviu-se da representação gráfica por meio da figura dos gráficos e a representação numérica quantitativa através dos quadros organizados com base nas variáveis selecionadas e seus respectivos atributos, visando à apresentação dos números absolutos disponibilizados e aqui tratados.

\subsection{1. - Características dos acidentes de trânsito}

Para conhecer sobre as características dos acidentes, foram feitos os cruzamentos dos dados referentes aos registros de ocorrências de acidentes por tipos de veículos, além das condições e características das vias para cada ano, ou seja, de 2000 a 2004.

No gráfico 1 e quadro 2, encontram-se os números de acidentes de trânsito para os anos de 2000 a 2004, referentes aos tipos de veículos envolvidos, ou seja, caminhão, carro, bicicleta, moto, ônibus, pedestre e outros. Os carros constam de, aproximadamente, metade dos registros totais dos tipos de veículos, sobressaindo em relação aos outros, e, na seqüência, aparecem as motos participando com aproximados $16 \%$ do total de veículos envolvidos em acidentes registrados na área urbana de Uberlândia. 
Gráfico 1 - Número de acidentes por ano sobre os tipos de veículos envolvidos, 2000 a 2004

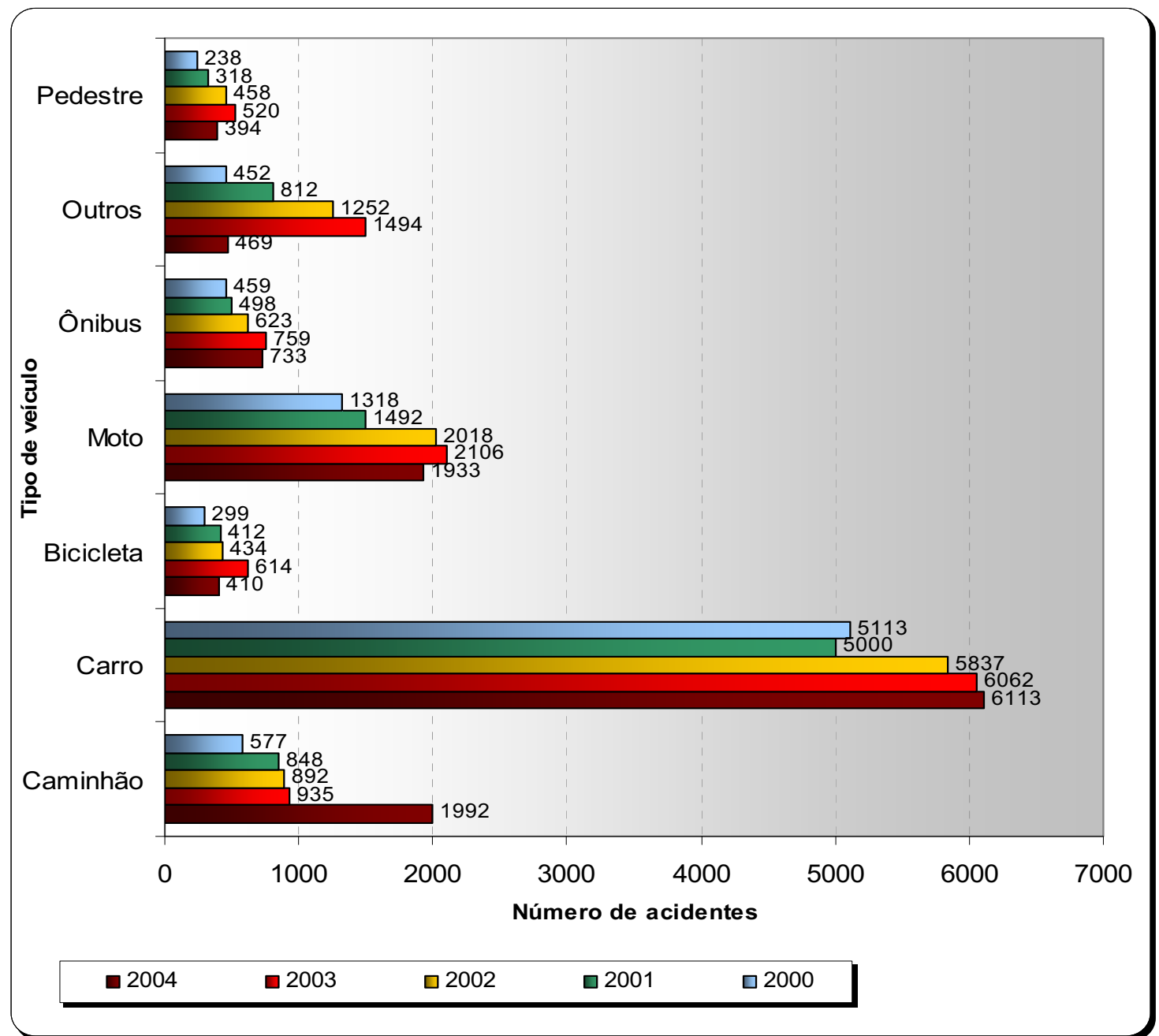

Org: BERNARDINO, A.R., 2006.

Fonte: SETTRAN, 2005.

Quadro 2 - Número de acidentes por ano em relação ao tipo de veículo envolvido, 2000 a 2004

\begin{tabular}{|c|c|c|c|c|c||}
\hline VEICULO/ ANO & $\mathbf{2 0 0 0}$ & $\mathbf{2 0 0 1}$ & $\mathbf{2 0 0 2}$ & $\mathbf{2 0 0 3}$ & $\mathbf{2 0 0 4}$ \\
\hline Caminhão & 577 & 848 & 892 & 935 & 1992 \\
\hline Carro & 5113 & 5000 & 5837 & 6062 & 6113 \\
\hline Bicicleta & 299 & 412 & 434 & 614 & 410 \\
\hline Moto & 1318 & 1492 & 2018 & 2106 & 1933 \\
\hline Ônibus & 459 & 498 & 623 & 759 & 733 \\
\hline Outros & 452 & 812 & 1252 & 1494 & 469 \\
\hline Pedestre & 238 & 318 & 458 & 520 & 394 \\
\hline Total & 8456 & 9380 & 11514 & 12490 & 12044 \\
\hline \hline
\end{tabular}

Org: BERNARDINO, A.R., 2006.

Fonte: SETTRAN, 2005. 
Sabe-se que o automóvel passou a fazer parte do cenário dos meios de transportes somente no final do século XIX e que, a partir de 1899, a produção em larga escala foi iniciada, principalmente nos Estados Unidos, pela Companhia Ford e, posteriormente, pela General Motors. Em meados de 1920, nesse país, 10 milhões de veículos já estavam registrados.

Diante desse ambiente e transcorrido quase um século de muitas transformações sócio-econômicas e culturais, não foi diferente para a crescente produção e demandas pautadas nos veículos. Hoje, o automóvel é parte que compõe qualquer cidade.

Uberlândia, cuja estimativa do IBGE referente aos habitantes para o ano de 2005 foi de 585 mil, além do que consolidou uma frota efetiva de 205 mil veículos (junho de 2006), alcançando, assim, uma taxa de motorização de 2,8 pessoas para cada veículo.

Remete-se, aqui, aos números apresentados na tabela 14 sobre a evolução da frota de Uberlândia observada desde o ano de 2002, com uma taxa de $4,8 \%$ ao ano, chega ao final do ano de 2005 , com a taxa de $6,3 \%$ de crescimento da frota total efetiva da cidade, somando, até junho de 2006, 205.510 veículos.

Para uma cidade localizada estrategicamente e receptora de visitantes e trabalhadores advindos das cidades regionais, como Araguari, Prata, Monte Alegre de Minas, Uberaba, Tupaciguara, Itumbiara, Patrocínio, Araxá, Patos de Minas, entre outras, tal situação leva ao "inchamento" de suas áreas de atratividade, como o centro da cidade e seu entorno, assim como os shoppings, fazendo jus aos registros freqüentes das ocorrências urbanas, no que se refere à segurança em geral da cidade, neste caso, aos acidentes de trânsito. 
Dentre os acidentes de transporte, especificadamente, os ocorridos com veículos motorizados constituem-se em importante causa de morte não natural.

Mello Jorge (1979 apud MELLO JORGE e KOIZUMI, 2006) conta que, em 1893, São Paulo recebia o primeiro carro que circulou nas suas ruas, o qual era conduzido por Henrique Santos Dumont e movido a vapor. Quatro anos mais tarde, no Rio de Janeiro, o poeta Olavo Bilac conduzia o veículo de seu amigo José do Patrocínio que colidindo contra uma árvore o transformou em sucata, sendo este conhecido como o primeiro acidente automobilístico brasileiro.

Pelos resultados apresentados, constata-se que o veículo tipo carro é o de maior demanda, e sua disseminação ocorreu devido ao desenvolvimento tecnológico, cujos veículos apresentaram cada vez mais desempenho, no sentido de velocidades mais altas e os preços mais acessíveis. Fatos estes responsáveis, em parte, pelo crescente número de acidentes automobilísticos nas rodovias e nas áreas urbanas.

Acresce-se, também, a esse aspecto, a produção das montadoras, chegando a 1,8 milhões de veículos/ano (GEIPOT, 2001), sendo que os veículos automotores ultrapassaram a marca de $80 \%$ da produção, e os movidos a gasolina atingiram $88 \%$ em relação ao diesel e ao álcool (cf. tabela 4).

Esses processos sócio-econômicos e culturais ocorreram com muita rapidez, o que difere do processo de concepção, votação e aprovação das leis que regem a segurança viária e que não conseguem acompanhar a velocidade das inovações tecnológicas, neste caso, referentes aos automóveis. 
Considerando as condições presumíveis da via na comparação entre os anos de 2000 a 2004 (cf. gráfico 2 e quadro 3), observa-se que os dois opostos, pista seca e molhada, aparecem nos registros das ocorrências, sendo que, em pista seca, o número dos acidentes ocorridos no trânsito são nitidamente muito superiores à outra condição.

Reconhece-se como característica do clima da região mineira, onde está localizada a cidade de Uberlândia, a alternância de invernos secos (abril a setembro) e verões chuvosos (outubro a março).

Entretanto, sabe-se que, anualmente, os números de dias de tempo seco superam os de chuva, além de poder ocorrer condições de via molhada por motivos aleatórios ao tempo, situações que também podem compor este quadro. Assim, o estado do pavimento não foi um fator significante, pois atinge cerca de até $11 \%$ os eventos de acidentes de trânsito ocorridos nas vias urbanas em condições molhadas.

É importante que as condições do piso das pistas de rolamentos sejam verificadas ou reconhecidas pelos condutores por meio de sinalizações, pois, além da instabilidade que o piso molhado provoca, também, as ondulações, buracos, elevações, inclinações ou alterações no tipo de piso podem desestabilizar o veículo, provocar a perda do controle, ficando este em estado vulnerável, facilitando a ocorrência de um acidente. 
Gráfico 2 - Número de acidentes considerando as condições presumíveis da via, 2000 a 2004

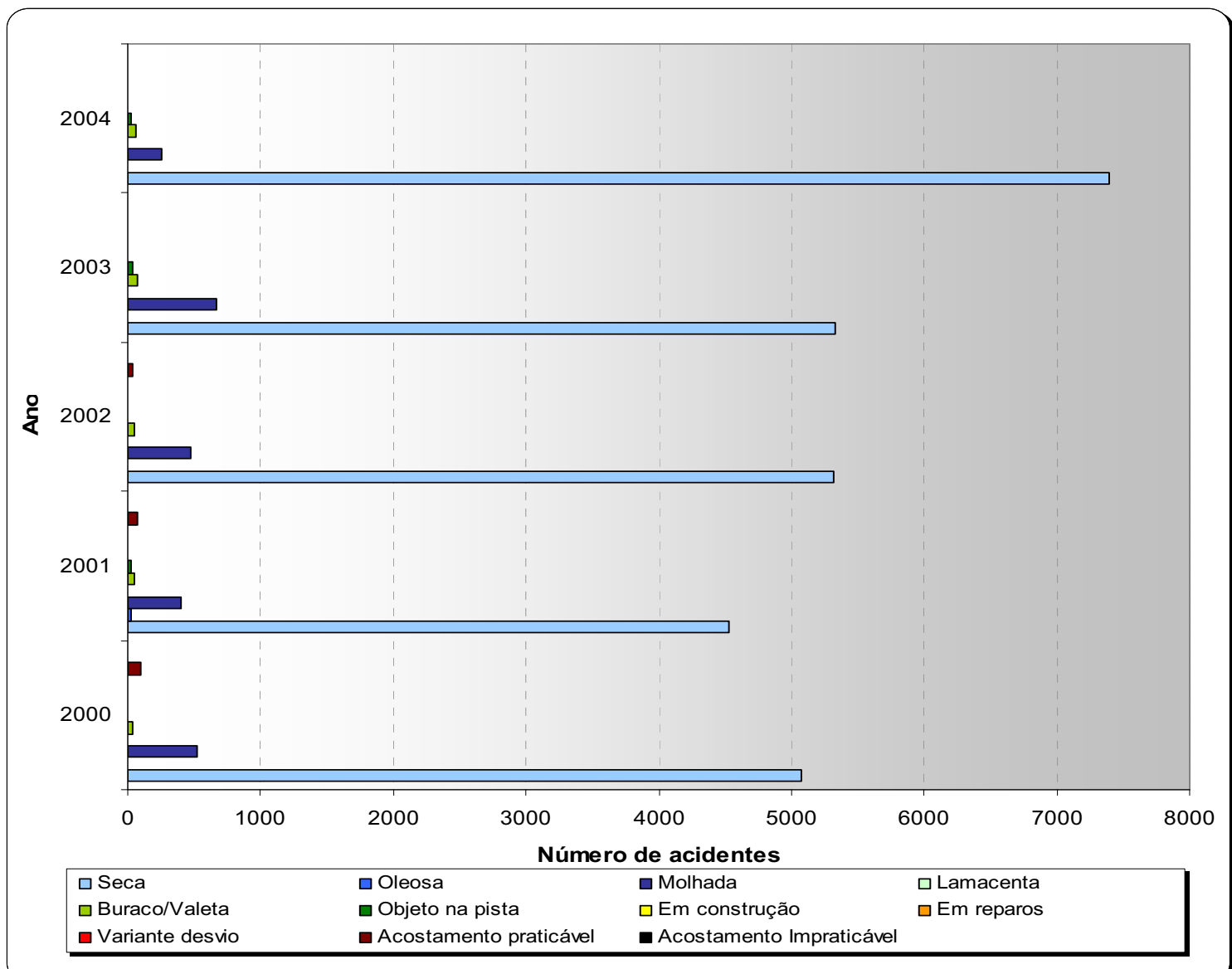

Org: BERNARDINO, A.R., 2006.

Fonte: SETTRAN, 2005

Quadro 3 - Número de acidentes considerando as condições presumíveis da via, 2000 a 2004

\begin{tabular}{|l|c|c|c|c|c|c|c||}
\hline CONDIÇÕES DA VIA / ANO & $\mathbf{2 0 0 0}$ & $\mathbf{2 0 0 1}$ & $\mathbf{2 0 0 2}$ & $\mathbf{2 0 0 3}$ & $\mathbf{2 0 0 4}$ & Total & $\%$ \\
\hline Seca & 5079 & 4523 & 5315 & 5331 & 7392 & 27640 & 90,2 \\
\hline Oleosa & 11 & 20 & 18 & 12 & 13 & 74 & 0,2 \\
\hline Molhada & 528 & 395 & 470 & 662 & 253 & 2308 & 7,5 \\
\hline Lamacenta & 2 & 1 & 1 & 5 & 2 & 11 & 0,0 \\
\hline Buraco/Valeta & 34 & 44 & 43 & 67 & 58 & 246 & 0,8 \\
\hline Objeto na pista & 10 & 21 & 15 & 33 & 19 & 98 & 0,3 \\
\hline Em construção & 2 & 4 & 2 & 2 & 1 & 11 & 0,0 \\
\hline Em reparos & 2 & 4 & 5 & 4 & 3 & 18 & 0,1 \\
\hline Variante desvio & 0 & 0 & 0 & 0 & 0 & 0 & 0 \\
\hline Acostamento praticável & 96 & 73 & 37 & 17 & 0 & 223 & 0,7 \\
\hline Acostamento Impraticável & 0 & 0 & 0 & 0 & 0 & 0 & 0 \\
\hline
\end{tabular}

Org: BERNARDINO, A.R., 2006.

Fonte: SETTRAN, 2005. 
O gráfico 3 e o quadro 4 apresentam os números dos acidentes de trânsito para os atributos referentes às características das vias que tiveram ocorrências de eventos. Os dados representativos nesta variável indicam os "cruzamentos" das vias e as "retas" como aquelas que registraram maior número de acidentes. $\mathrm{Na}$ seqüência, em volume bem inferior a estes, aparecem as características viárias de declive e aclive, que também puderam ser observadas.

Embora se evidencie, nos principais cruzamentos (cf. item 3.2.3) em que são freqüentes os acidentes, a presença da sinalização semafórica, indicando o tratamento e atenção para esses locais, considera-se que o fator comportamental dos condutores e pedestres sobressai.

Gráfico 3 - Número de acidentes considerando as características da via por ano, 2000 a 2004

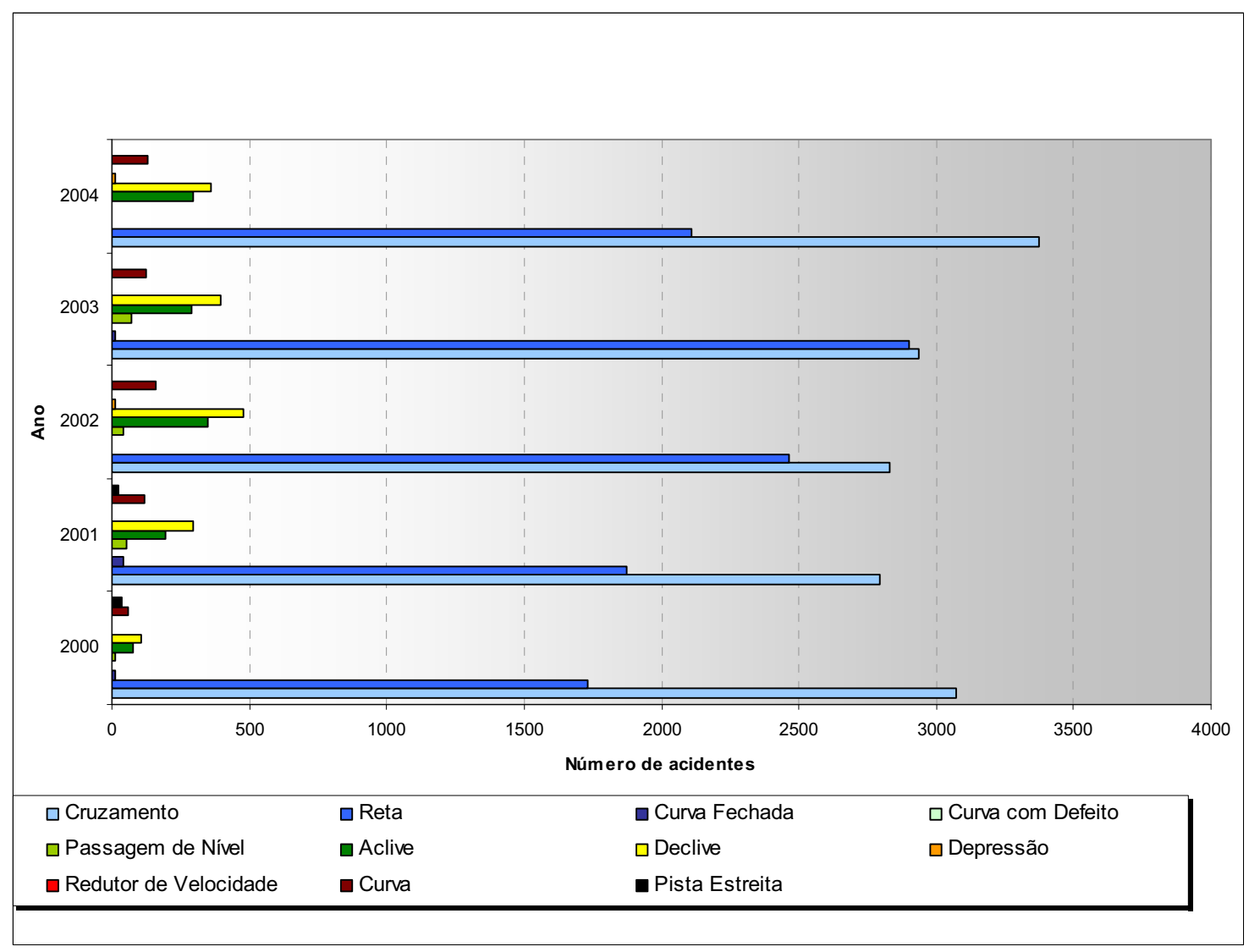

Org: BERNARDINO, A.R., 2006.

Fonte: SETTRAN, 2005. 
Quadro 4 - Número de acidentes considerando as características da via, 2000 a 2004

\begin{tabular}{|l|c|c|c|c|c||}
\hline CARACTERISTICAS DA VIA/ ANO & $\mathbf{2 0 0 0}$ & $\mathbf{2 0 0 1}$ & $\mathbf{2 0 0 2}$ & $\mathbf{2 0 0 3}$ & $\mathbf{2 0 0 4}$ \\
\hline Cruzamento & 3075 & 2796 & 2829 & 2937 & 3375 \\
\hline Reta & 1731 & 1874 & 2466 & 2900 & 2107 \\
\hline Curva Fechada & 11 & 39 & 5 & 10 & $\mathrm{~s} / \mathrm{i}$ \\
\hline Curva com Defeito & 2 & 2 & 1 & 3 & $\mathrm{~s} / \mathrm{i}$ \\
\hline Passagem de Nível & 11 & 56 & 44 & 72 & $\mathrm{~s} / \mathrm{i}$ \\
\hline Aclive & 74 & 194 & 349 & 291 & 294 \\
\hline Declive & 105 & 298 & 478 & 398 & 358 \\
\hline Depressão & 2 & 2 & 11 & 4 & 14 \\
\hline Redutor de Velocidade & 2 & 5 & 3 & 8 & 8 \\
\hline Curva & 61 & 117 & 157 & 125 & 132 \\
\hline Pista Estreita & 33 & 24 & 2 & 5 & $\mathrm{~s} / \mathrm{i}$ \\
\hline \hline
\end{tabular}

Legenda: s/i = sem informação

Org: BERNARDINO, A.R., 2006.

Fonte: SETTRAN, 2005.

\subsection{2. - Causas presumíveis dos acidentes de trânsito}

Para as causas dos acidentes de trânsito, o cruzamento desses dados foram relacionados com a severidade dos acidentes para os anos de 2000 a 2003 e para o ano de 2004, sendo os itens a ela atribuídos: os danos materiais, os feridos leves, os feridos graves e os mortos.

A variável "causas presumíveis dos acidentes" exigiu o desmembramento dos anos de 2000 a 2003 com o ano de 2004, para fins de comparação entre os anos. Este procedimento não alterou a análise, pois as ocorrências dos atributos referentes a esta variável apareceram na seqüência para todos os anos, ou seja, de 2000 a 2004.

Nos gráficos de 4 a 7 , observa-se que, para as causas presumíveis dos acidentes, os atributos "não usou os freios", "mudou subitamente de direção", "excesso de velocidade" e "desobedeceu ao sinal de pare" foram freqüentes e mais expressivos nos anos 2000 a 2003, apresentando-se ocorrências em todas as severidades, ou seja, acidentes ocorridos em razão dessas principais causas, tendo como conseqüências os volumes proporcionais relativos aos danos materiais, feridos leves, feridos graves e mortos. 
Gráfico 4 - Número de acidentes por severidade (danos materiais) relacionados com as causas presumíveis, 2000 a 2003

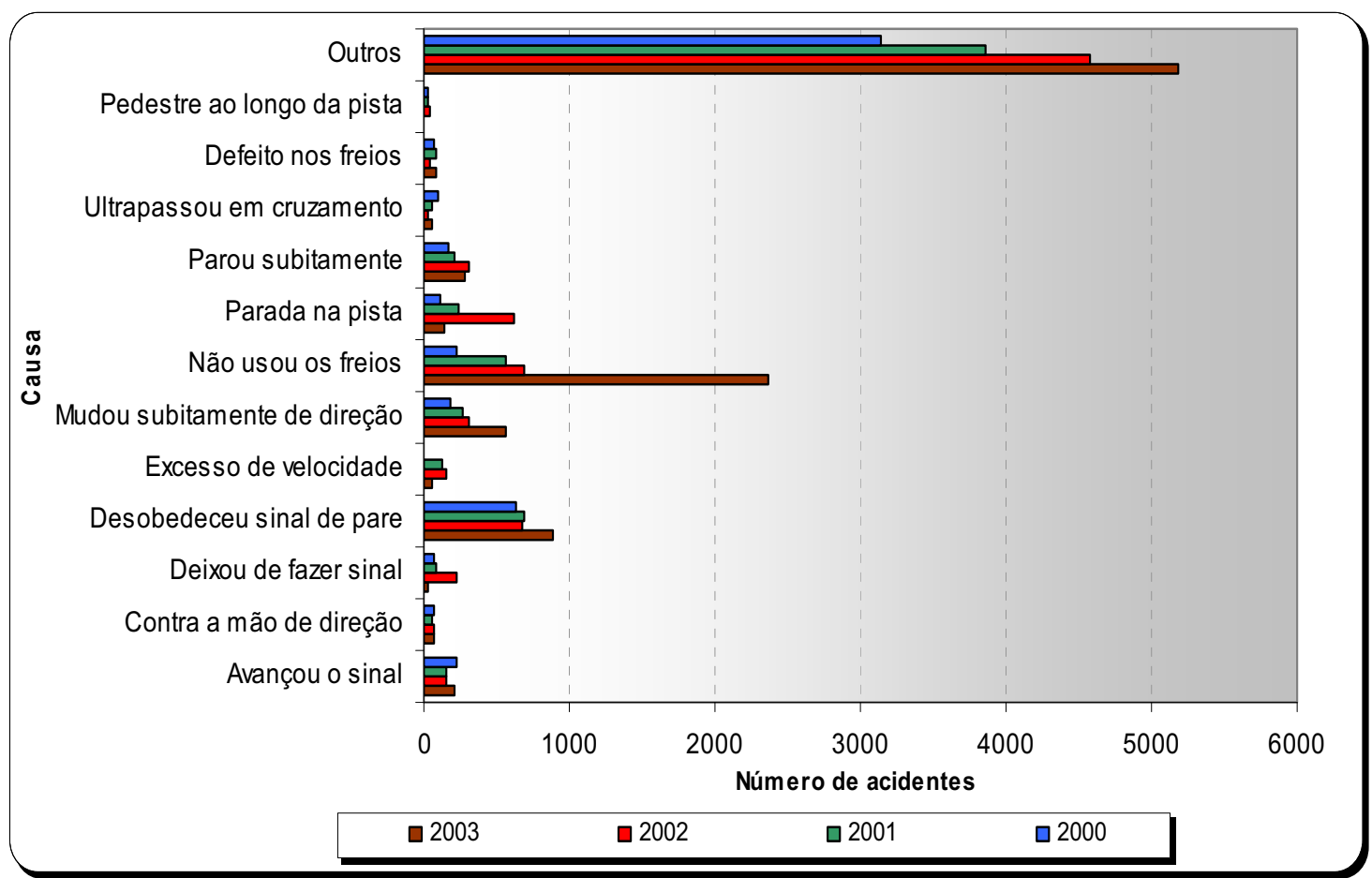

Org: BERNARDINO, A.R., 2006.

Fonte: SETTRAN, 2005.

Gráfico 5 - Número de acidentes por severidade (feridos leves) relacionados com as causas presumíveis, 2000 a 2003

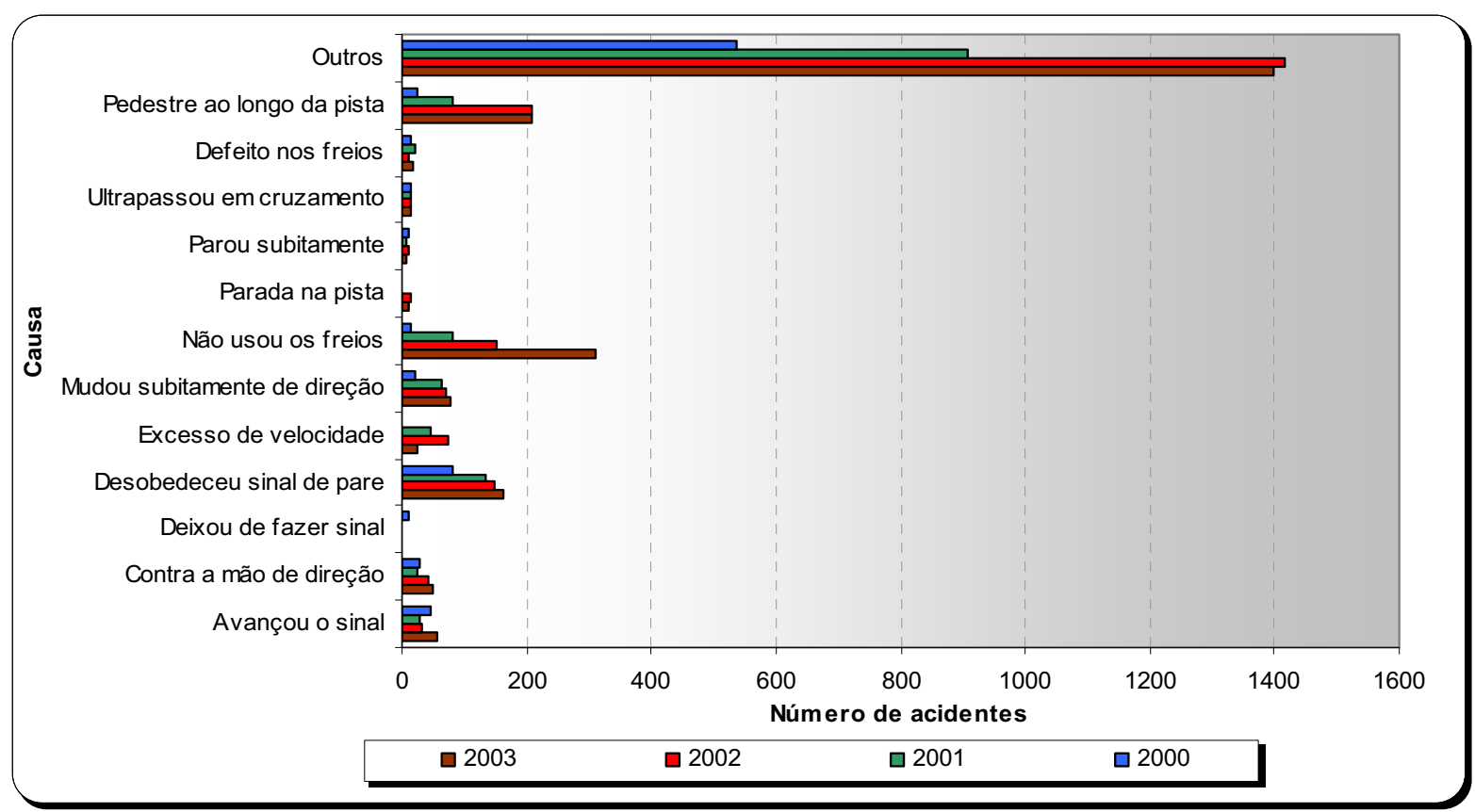

Org: BERNARDINO, A.R., 2006.

Fonte: SETTRAN, 2005. 
Gráfico 6 - Número de acidentes por severidade (feridos graves) relacionados com as causas presumíveis, 2000 a 2003

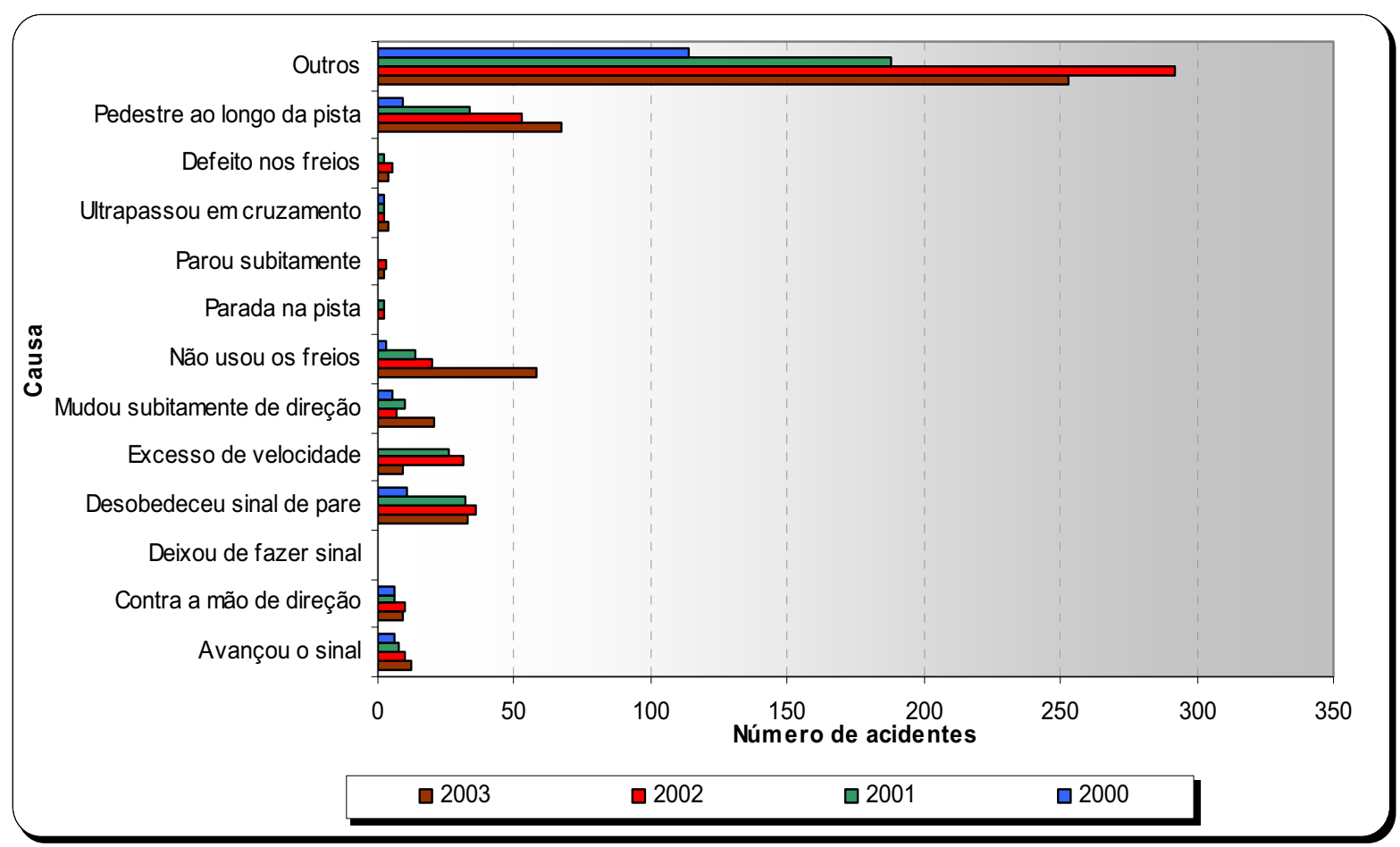

Org: BERNARDINO, A.R., 2006.

Fonte: SETTRAN, 2005.

Gráfico 7 - Número de acidentes por severidade (mortos) relacionados com as causas presumíveis, 2000 a 2003

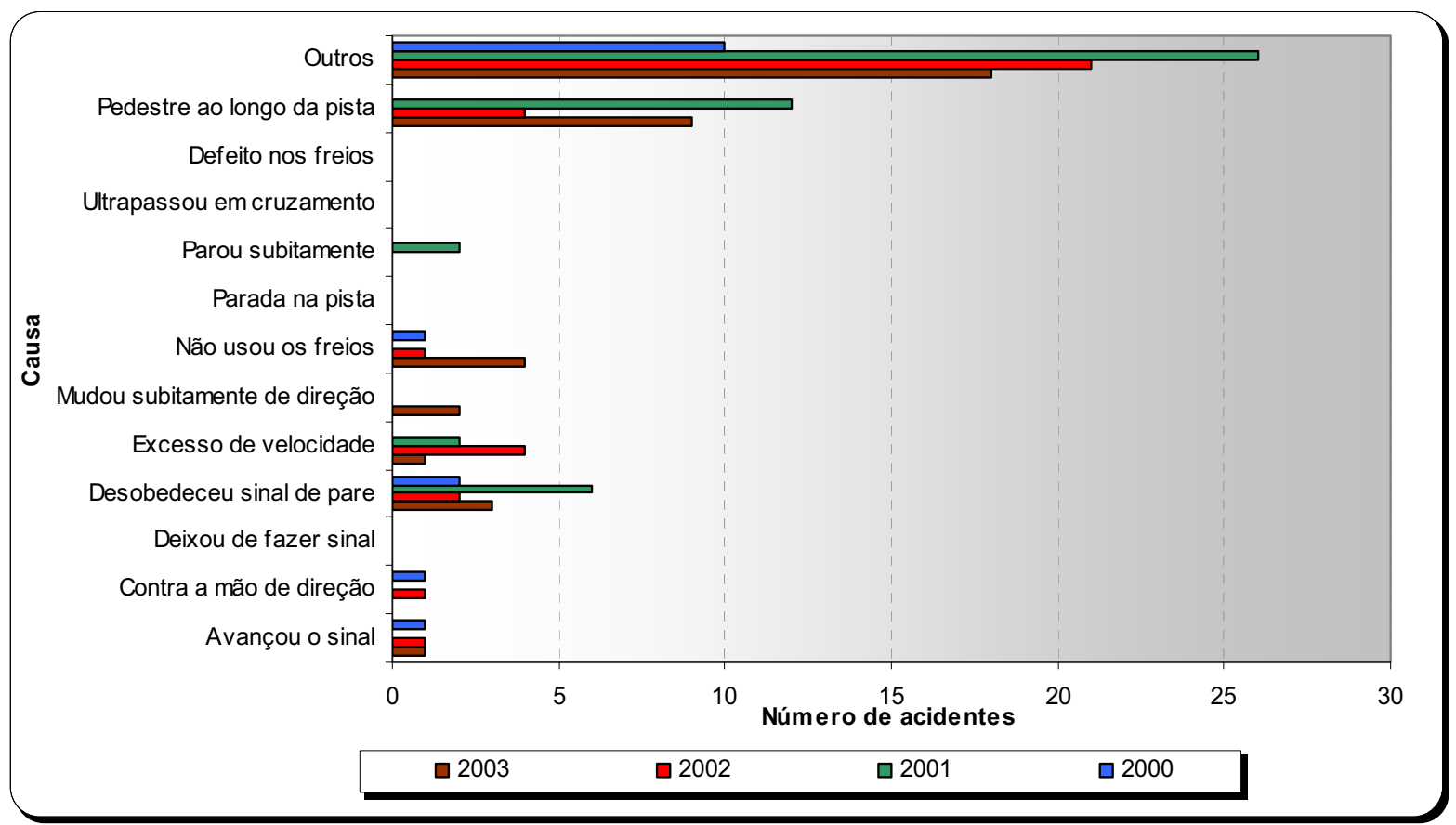

Org: BERNARDINO, A.R., 2006.

Fonte: SETTRAN, 2005. 
Observa-se que as causas que mais apareceram nessa variável demonstram que, se associadas ao fator comportamental dos condutores, como: pedestres ao longo da via, o desrespeito à sinalização semafórica, desobediência ao sinal de PARE e a não utilização dos freios na ocasião, apresentaram-se como as principais causas dos acidentes ocorridos no trânsito.

Quanto a severidade "mortos" (cf. gráfico 7), observa-se, que a proporção do atributo "pedestres ao longo da pista" supera em quantidade de ocorrências, se comparado aos demais atributos, o que demonstra o conflito intenso durante os deslocamentos dos cidadãos e os veículos.

O defeito nos freios, é outra detectada, além da ultrapassagem em cruzamentos, parada súbita, parada na pista, deixou de fazer sinal, contramão de direção, avançar o sinal, que também são muito importantes, tendo em vista a sua ligação com o comportamento individual do condutor.

O quadro 5 expõe as informações de percentual para cada uma das causas atribuídas aos acidentes de trânsito, que mostra o atributo "desobedeceu ao sinal de pare" como aquela em que mais houve ocorrência para os anos de 2000, 2001 e 2002. O ano de 2003 a causa mais significativa foi "não usou freios". 


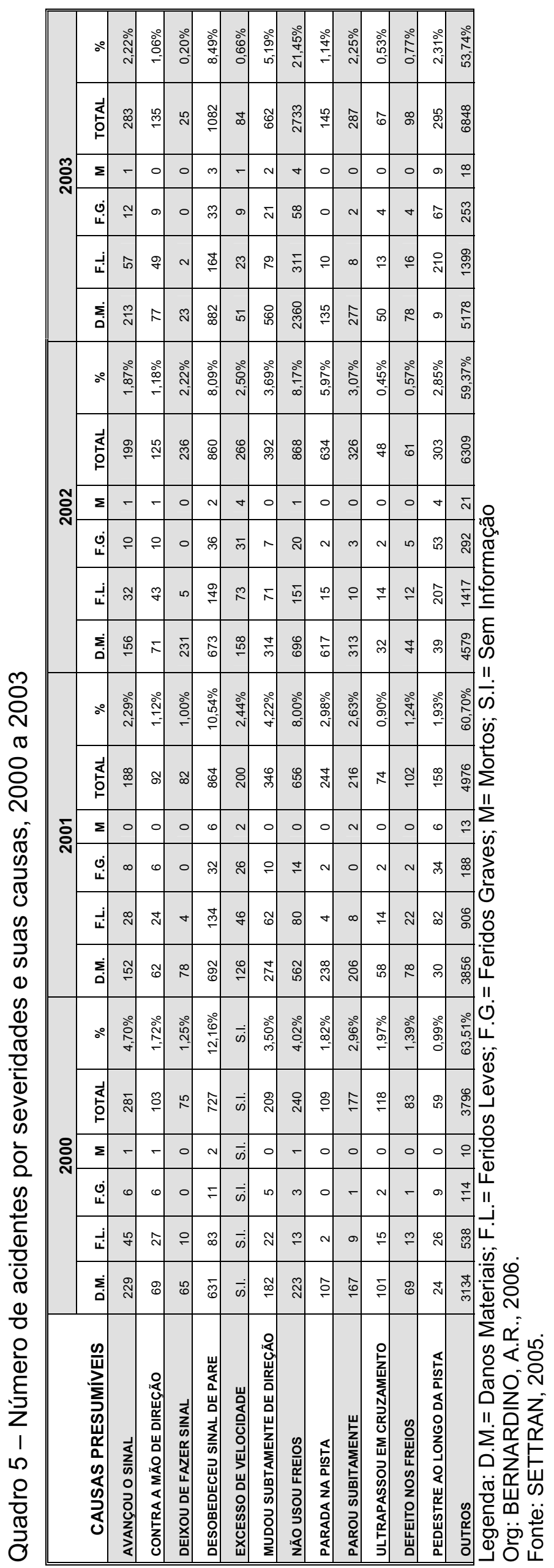


O gráfico 8 e quadro 6 demonstraram os dados do ano de 2004, em que as causas mais freqüentes não se revelaram diferentes da ligação com o comportamento do condutor, tendo em vista que os atributos "não usou freios, desobedeceu ao sinal de PARE além da falta de atenção" ficaram dentre as constantes entre as que ocorreram no ano de 2004.

Gráfico 8 - Número de acidentes por severidade relacionados às causas presumíveis, 2004

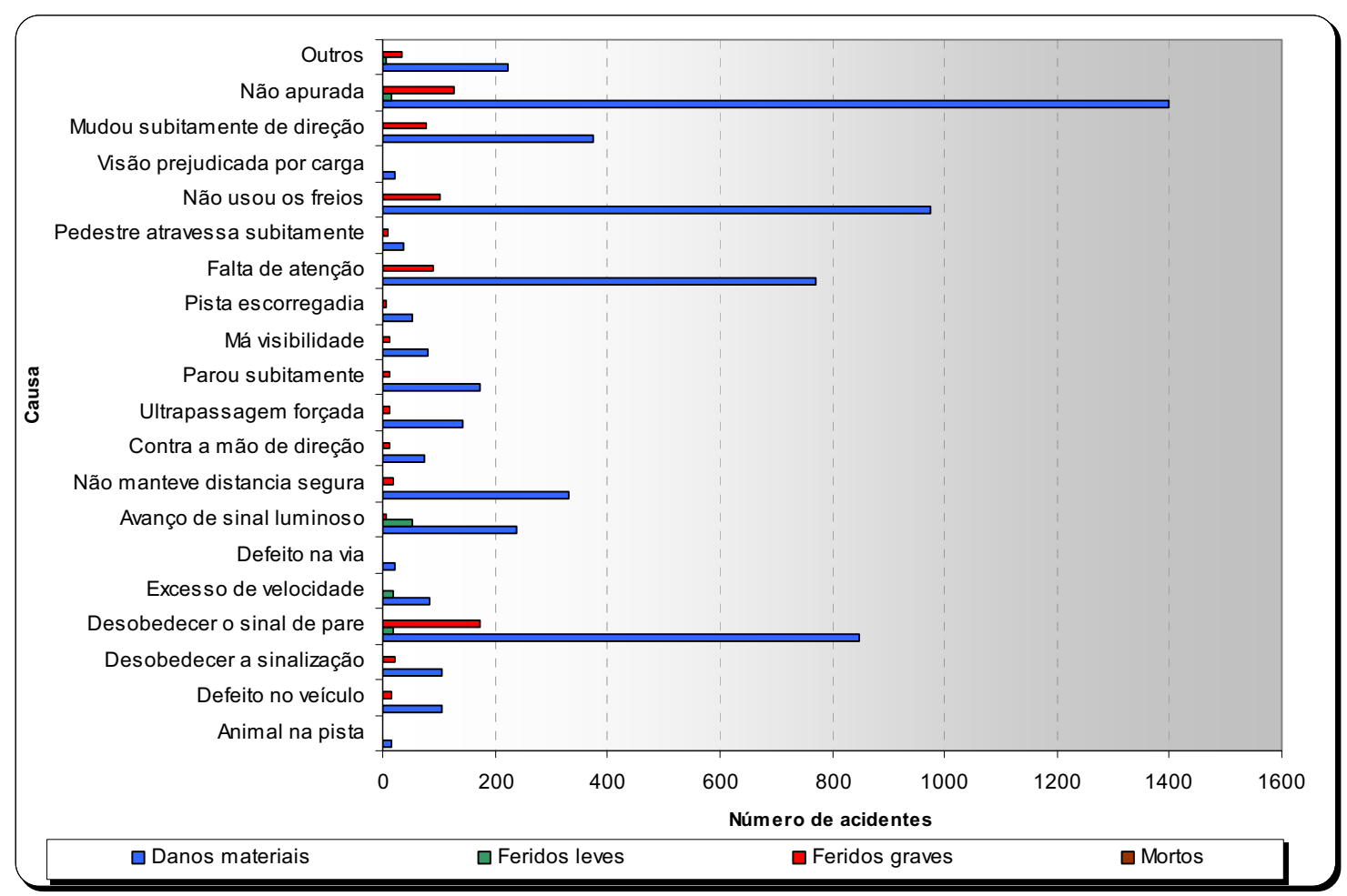

Org: Bernardino, A.R., 2006.

Fonte: SETTRAN, 2005.

Referente aos atos dos condutores, Concha-Eastman e AceroVelásquez (2006) acrescentam que determinados atos como: retornos indevidos; cruzamento de semáforos em tempo proibido; desenvolvimento de altas velocidades; estacionamentos proibidos; a não utilização das passarelas para pedestres; transitar por debaixo delas; cruzar a rua entre os veículos; dirigir embriagado, entre outros, são comportamentos de pessoas que não conseguem dimensionar as conseqüências de seus impulsos e sua implicação na vida de outros e de si mesmas, que ativam as causas que tornam o trânsito mais inseguro. 
Quadro 6 - Número de acidentes por severidades relacionados às causas presumíveis, 2004

\begin{tabular}{||l|c|c|c|c|c|c||}
\hline CAUSAS / SEVERIDADE & $\begin{array}{c}\text { Danos } \\
\text { Materiais }\end{array}$ & $\begin{array}{c}\text { Feridos } \\
\text { Leves }\end{array}$ & $\begin{array}{c}\text { Feridos } \\
\text { Graves }\end{array}$ & Mortos & Total & $\%$ \\
\hline Avanço de sinal luminoso & 237 & 54 & 5 & 0 & 296 & 4,2 \\
\hline Contra a mão de direção & 75 & 11 & 2 & 0 & 88 & 1,3 \\
\hline Desobedecer a sinalização & 106 & 22 & 4 & 0 & 132 & 1,9 \\
\hline Desobedecer sinal de PARE & 848 & 174 & 18 & 1 & 1041 & 15,8 \\
\hline Excesso de velocidade & 83 & 20 & 1 & 0 & 104 & 1,5 \\
\hline $\begin{array}{l}\text { Mudou subitamente de } \\
\text { direção }\end{array}$ & 374 & 78 & 3 & 0 & 455 & 6,5 \\
\hline Não usou os freios & 975 & 103 & 3 & 1 & 1082 & 15,5 \\
\hline Não manteve distancia segura & 331 & 19 & 0 & 0 & 350 & 5,0 \\
\hline Parou subitamente & 172 & 12 & 3 & 0 & 187 & 2,7 \\
\hline Ultrapassagem forçada & 142 & 12 & 1 & 0 & 155 & 2,2 \\
\hline Defeito no veículo & 105 & 15 & 3 & 0 & 123 & 1,8 \\
\hline Pedestre atravessa & 38 & 10 & 2 & 0 & 50 & 0,7 \\
\hline subitamente & 81 & 12 & 1 & 0 & 94 & 1,3 \\
\hline Má visibilidade & 770 & 89 & 1 & 0 & 860 & 12,4 \\
\hline Falta de atenção & 52 & 7 & 0 & 0 & 59 & 0,8 \\
\hline Pista escorregadia & 22 & 4 & 0 & 0 & 26 & 0,4 \\
\hline Defeito na via & 16 & 4 & 0 & 0 & 20 & 0,3 \\
\hline Animal na pista & 22 & 3 & 0 & 0 & 25 & 0,4 \\
\hline Visão prejudicada por carga & 1398 & 128 & 16 & 2 & 1544 & 22,2 \\
\hline Não apurada & 35 & 6 & 0 & 265 & 3,8 \\
\hline Outros & 224 & & & & & \\
\hline
\end{tabular}

Legenda: $s / i=$ sem informação

Org: BERNARDINO, A.R., 2006.

Fonte: SETTRAN, 2005.

Nesse contexto, salienta-se que o individualismo, o desafio de dominar o tempo, o desconhecimento das regras de convivência, entre outros aspectos, incrementam os conflitos na co-existência de pedestres, de veículos, do uso da infra-estrutura do trânsito e dos equipamentos urbanos. 
3.1.3 - Perfil dos condutores de veículos envolvidos em acidente

Para conhecer o perfil do condutor, foram realizados e selecionados os cruzamentos dos dados das variáveis dos grupos de idade, sexo e tempo de habilitação por severidade para todos os anos analisados (2000 a 2004).

Os cruzamentos dos dados referentes à faixa etária por severidade levam a confirmar que a idade considerada "ativa", entre 19 e 42 anos, é aquela em que está inserido o maior número de registros de acidentes, com destaque para a severidade "danos materiais" e "feridos leves" (cf. gráficos 9 e 10). Já para a faixa etária em que mais se destacam os feridos graves, observa-se redução no intervalo de idade, verificando que, acima de 30 anos, o número de ocorrências tende a reduzir (cf. gráfico 11).

Nota-se que ocorre uma evolução crescente na freqüência anual dos acidentes para os "danos materiais", "feridos leves" e "feridos graves" (cf. gráficos 9, 10 e 11), o que não ocorre para a severidade "mortos", em que qualquer análise de continuidade ou freqüência referente à faixa etária, por ano, dos condutores envolvidos em acidentes de trânsito não pode ser verificada (cf. gráfico 12).

Sobre os números absolutos dos acidentes registrados para a severidade "feridos graves" referente aos grupos de idade dos condutores, notou-se que, no ano de 2004, ocorreu a redução em suas ocorrências, quando comparados aos anos de 2001, 2002 e 2003. Mas observa-se que os mais jovens (13 a 18 anos) estão cada vez mais participando dos acidentes de trânsito na cidade, o que evidencia, também nesta questão, a precocidade das atividades sociais, levando a deslocamentos viários anteriormente não realizados. 
Dessa forma, mais transeuntes levam à majoração do fluxo de pessoas e veículos que adentram a área central da cidade nos setores mais atrativos, repercutindo, intensivamente, na ocorrência dos acidentes de trânsito.

Assim, observou-se que a fatalidade num evento decorrente de acidente de trânsito não é verificada somente numa determinada faixa de idade (cf. gráfico 12). Esta análise pode ser dada à existência de problemas gerais que provocam acidentes a qualquer hora do dia, além de qualquer indivíduo que não use as normas indicativas para a segurança viária poder estar vulnerável e participar em quaisquer uns desses eventos.

Gráfico 9 - Número de acidentes dos grupos de idade dos condutores relacionados com a severidade (danos materiais), 2000 a 2004

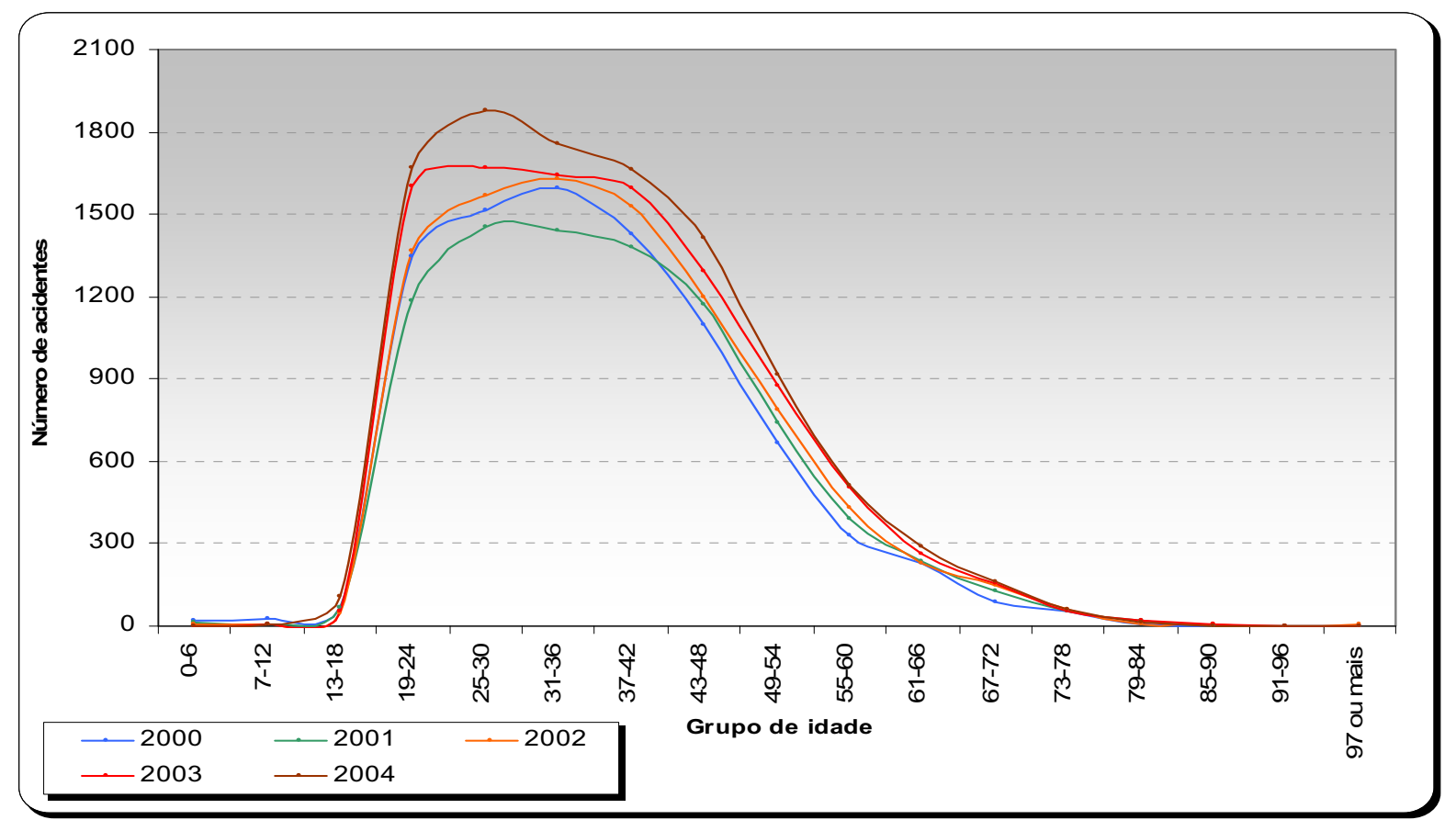

Org: Bernardino, A.R., 2006.

Fonte: SETTRAN, 2005. 
Gráfico 10 - Número de acidentes dos grupos de idade dos condutores relacionados com a severidade (feridos leves), 2000 a 2004

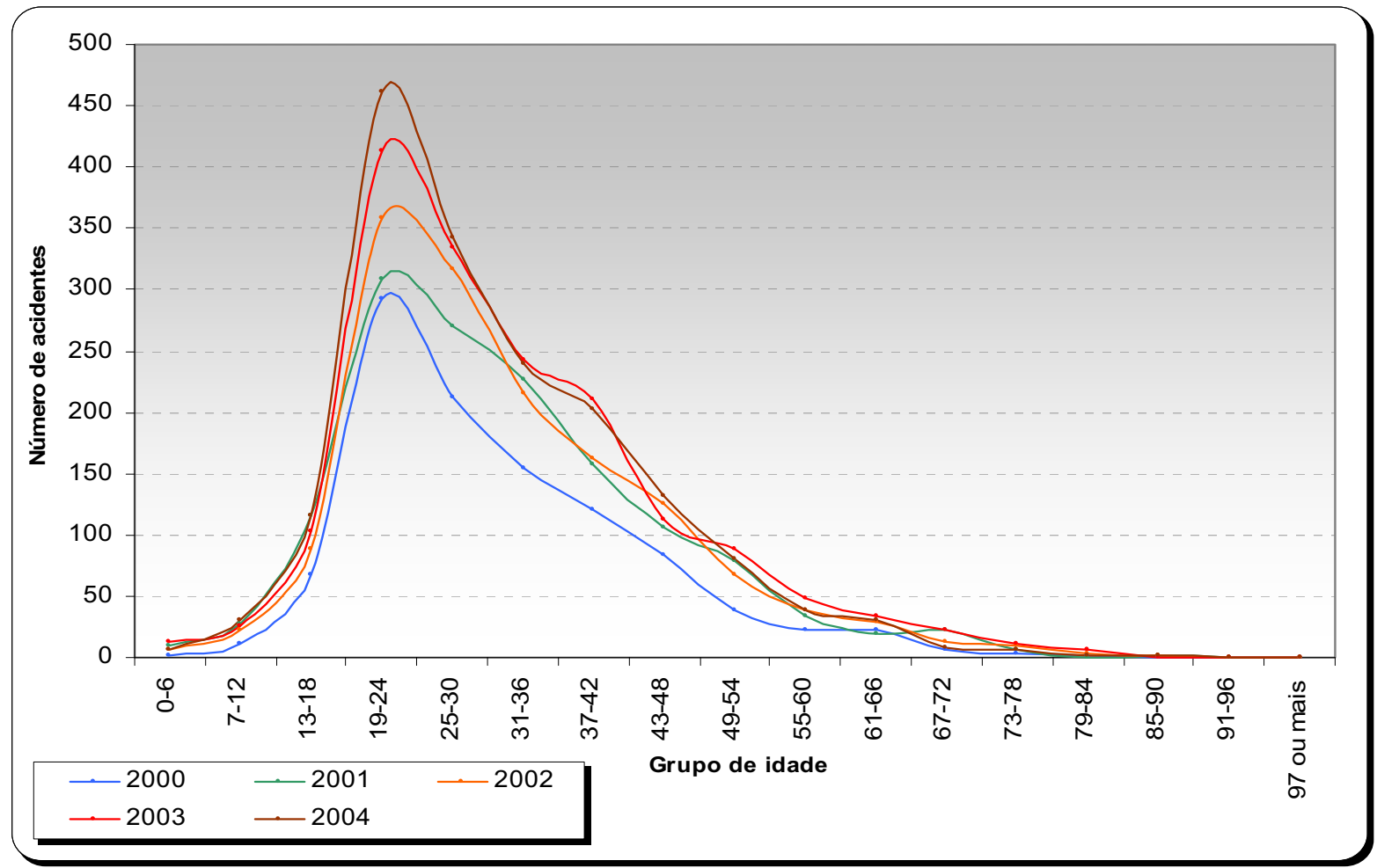

Org: Bernardino, A.R., 2006.

Fonte: SETTRAN, 2005.

Gráfico 11 - Número de acidentes dos grupos de idade dos condutores relacionados com a severidade (feridos graves), 2000 a 2004

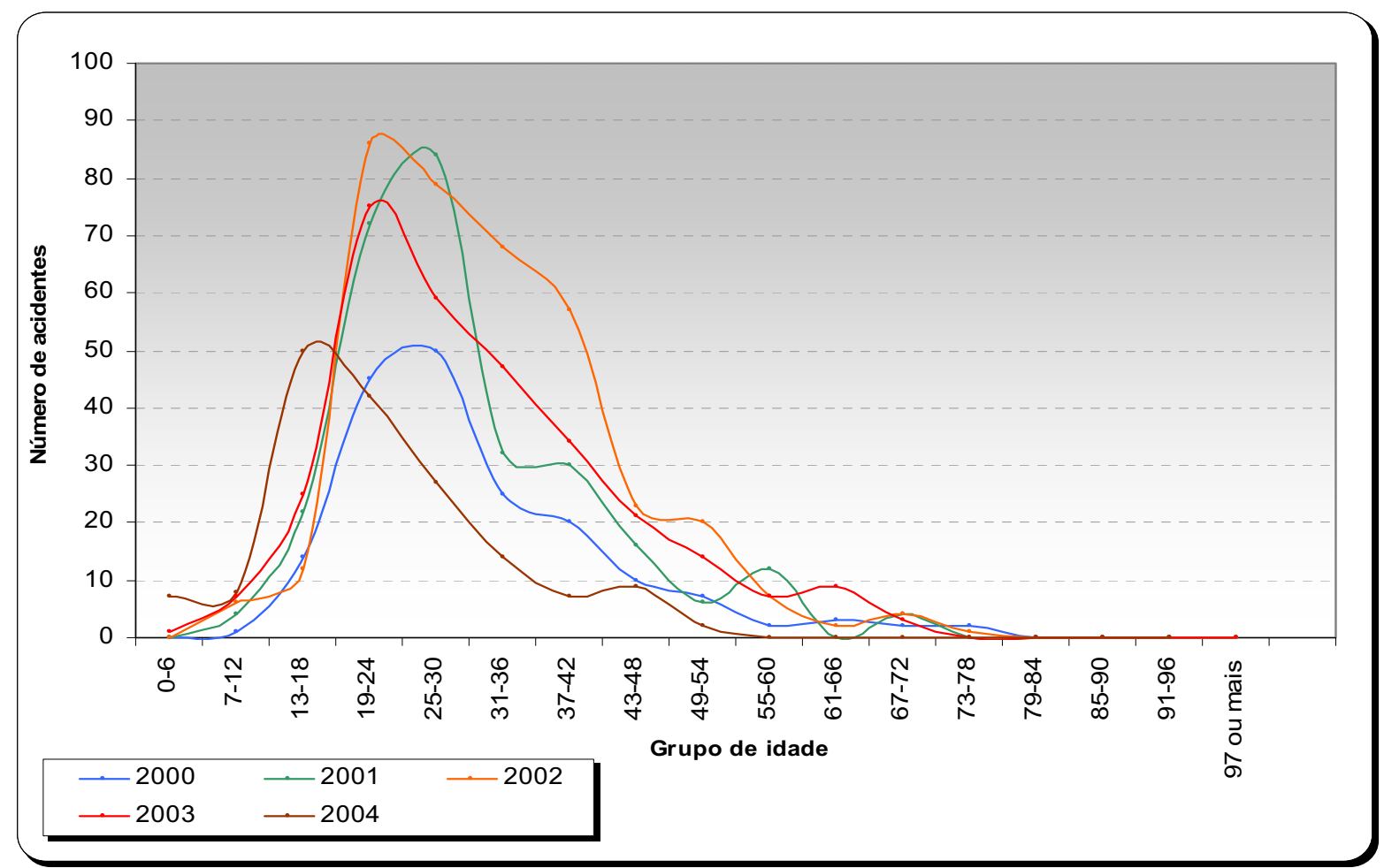

Org: Bernardino, A.R., 2006.

Fonte: SETTRAN, 2005. 
Gráfico 12 - Número de acidentes dos grupos de idade dos condutores relacionados com a severidade (mortos), 2000 a 2004

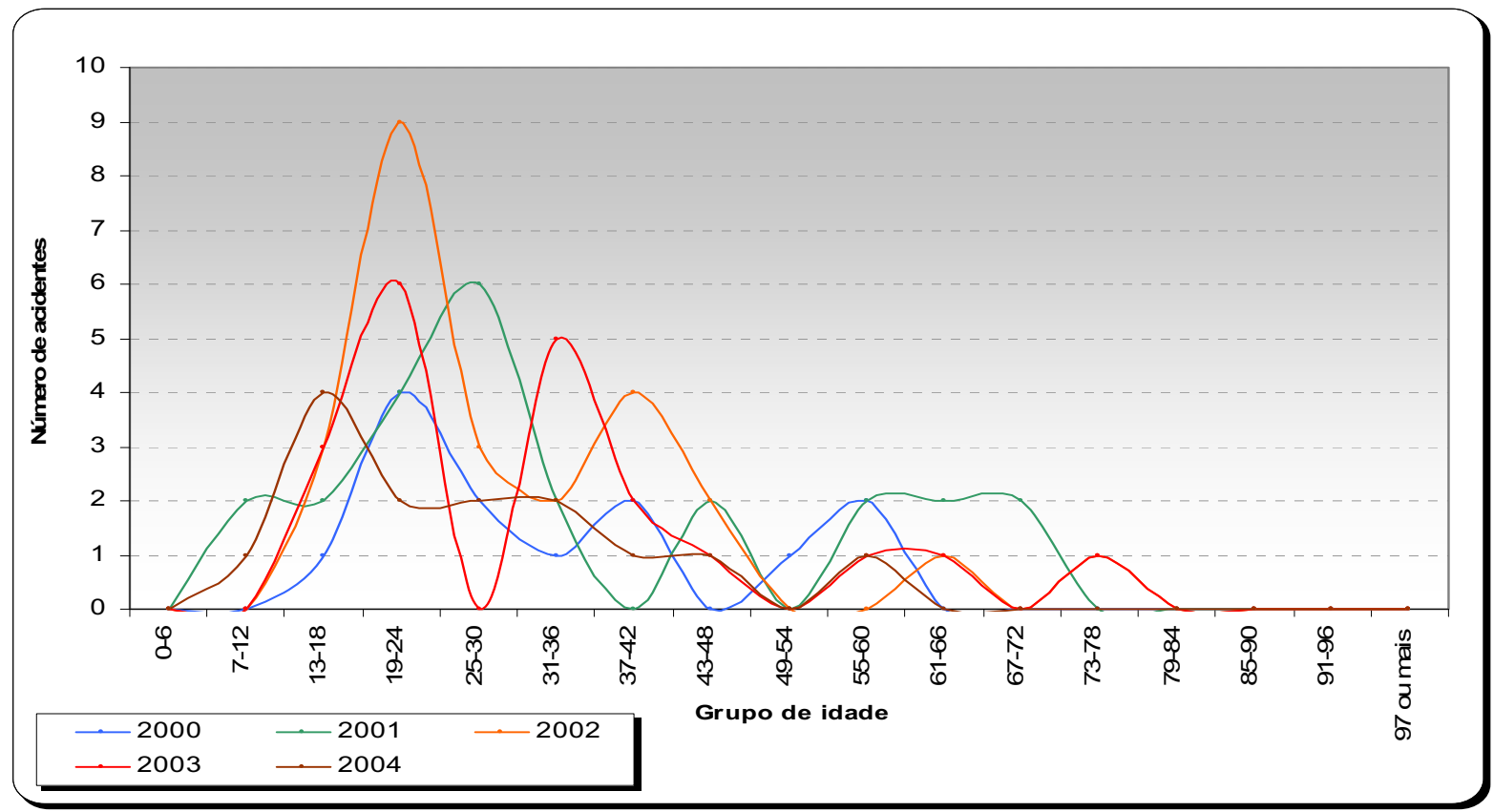

Org: Bernardino, A.R., 2006.

Fonte: SETTRAN, 2005.

Quadro 7 - Número de acidentes dos grupos de idade dos condutores relacionados com as severidades, 2000 a 2004

\begin{tabular}{|c|c|c|c|c|c|c|c|c|c|c|c|c|c|c|c|c|c|c|c|c|}
\hline \multirow{2}{*}{$\begin{array}{c}\text { IDADE / } \\
\text { SEVERIDADE }\end{array}$} & \multicolumn{4}{|c|}{2000} & \multicolumn{4}{|c|}{2001} & \multicolumn{4}{|c|}{2002} & \multicolumn{4}{|c|}{2003} & \multicolumn{4}{|c|}{2004} \\
\hline & D.M. & F.L. & F.G. & M & D. M. & F.L. & F.G. & M & D. M. & F.L. & F.G. & M & D. M. & F.L. & F.G & M & D. M. & F.L. & F.G. & M \\
\hline $0-6$ & 21 & 2 & 0 & 0 & 16 & 10 & 0 & 0 & 6 & 7 & 0 & 0 & 2 & 13 & 1 & 0 & 2 & 6 & 0 & 0 \\
\hline $7-12$ & 24 & 12 & 1 & 0 & 10 & 28 & 4 & 2 & 4 & 22 & 6 & 0 & 7 & 25 & 7 & 0 & 4 & 31 & 7 & 1 \\
\hline $13-18$ & 67 & 67 & 14 & 1 & 70 & 116 & 22 & 2 & 44 & 88 & 12 & 3 & 56 & 103 & 25 & 3 & 108 & 116 & 8 & 4 \\
\hline $19-24$ & 1347 & 292 & 45 & 4 & 1184 & 308 & 72 & 4 & 1363 & 359 & 86 & 9 & 1601 & 413 & 75 & 6 & 1670 & 461 & 50 & 2 \\
\hline 25-30 & 1516 & 213 & 50 & 2 & 1452 & 270 & 84 & 6 & 1569 & 316 & 79 & 3 & 1666 & 334 & 59 & 0 & 1881 & 342 & 42 & 2 \\
\hline $31-36$ & 1596 & 154 & 25 & 1 & 1440 & 226 & 32 & 2 & 1632 & 215 & 68 & 2 & 1643 & 242 & 47 & 5 & 1754 & 240 & 27 & 2 \\
\hline $37-42$ & 1425 & 121 & 20 & 2 & 1378 & 158 & 30 & 0 & 1530 & 162 & 57 & 4 & 1598 & 211 & 34 & 2 & 1662 & 202 & 14 & 1 \\
\hline $43-48$ & 1099 & 83 & 10 & 0 & 1170 & 106 & 16 & 2 & 1200 & 126 & 23 & 2 & 1291 & 113 & 21 & 1 & 1413 & 132 & 7 & 1 \\
\hline $49-54$ & 667 & 38 & 7 & 1 & 740 & 78 & 6 & 0 & 788 & 67 & 20 & 0 & 876 & 88 & 14 & 0 & 917 & 80 & 9 & 0 \\
\hline $55-60$ & 329 & 22 & 2 & 2 & 392 & 34 & 12 & 2 & 428 & 39 & 7 & 0 & 506 & 49 & 7 & 1 & 509 & 39 & 2 & 1 \\
\hline $61-66$ & 226 & 22 & 3 & 0 & 236 & 20 & 0 & 2 & 230 & 29 & 2 & 1 & 265 & 33 & 9 & 1 & 290 & 30 & 0 & 0 \\
\hline $67-72$ & 89 & 6 & 2 & 0 & 130 & 22 & 4 & 2 & 146 & 13 & 4 & 0 & 156 & 23 & 3 & 0 & 161 & 8 & 0 & 0 \\
\hline 73-78 & 52 & 3 & 2 & 0 & 56 & 6 & 0 & 0 & 62 & 10 & 1 & 1 & 56 & 12 & 0 & 1 & 63 & 6 & 0 & 0 \\
\hline 79-84 & 8 & 1 & 0 & 0 & 18 & 0 & 0 & 0 & 9 & 4 & 0 & 0 & 21 & 6 & 0 & 0 & 16 & 1 & 0 & 0 \\
\hline $85-90$ & 3 & 0 & 0 & 0 & 0 & 2 & 0 & 0 & 4 & 2 & 0 & 0 & 4 & 0 & 0 & 0 & 2 & 1 & 0 & 0 \\
\hline $91-96$ & 1 & 0 & 0 & 0 & 2 & 0 & 0 & 0 & 0 & 0 & 0 & 0 & 1 & 0 & 0 & 0 & 1 & 0 & 0 & 0 \\
\hline 97 ou mais & 0 & 0 & 0 & 0 & 2 & 0 & 0 & 0 & 4 & 0 & 0 & 0 & 0 & 0 & 0 & 0 & 0 & 0 & 0 & 0 \\
\hline
\end{tabular}

Legenda: D.M.= Danos Materiais; F.L.= Feridos Leves; F.G.= Feridos Graves; M= Mortos; Org: BERNARDINO, A.R., 2006.

Fonte: SETTRAN, 2005. 
Considerando por grupos, os homens e as mulheres, e verificando aqueles que mais participam em eventos referentes aos acidentes de trânsito, os homens aparecem em números expressivos nas ocorrências dos acidentes de trânsito (cf. gráfico 13), expondo a predominância do sexo masculino em todas as faixas etárias, na infância, na adolescência, na fase adulta e na maior idade.

Ao longo dos anos, mesmo em proporções diferentes, comparando os dois gêneros, o número de acidentes é progressivo, como pode ser visto nos gráficos 13 e 14 e quadro 8 .

Gráfico 13 - Número de acidentes por grupos de idade dos condutores dos veículos para o sexo masculino, 2000 a 2004

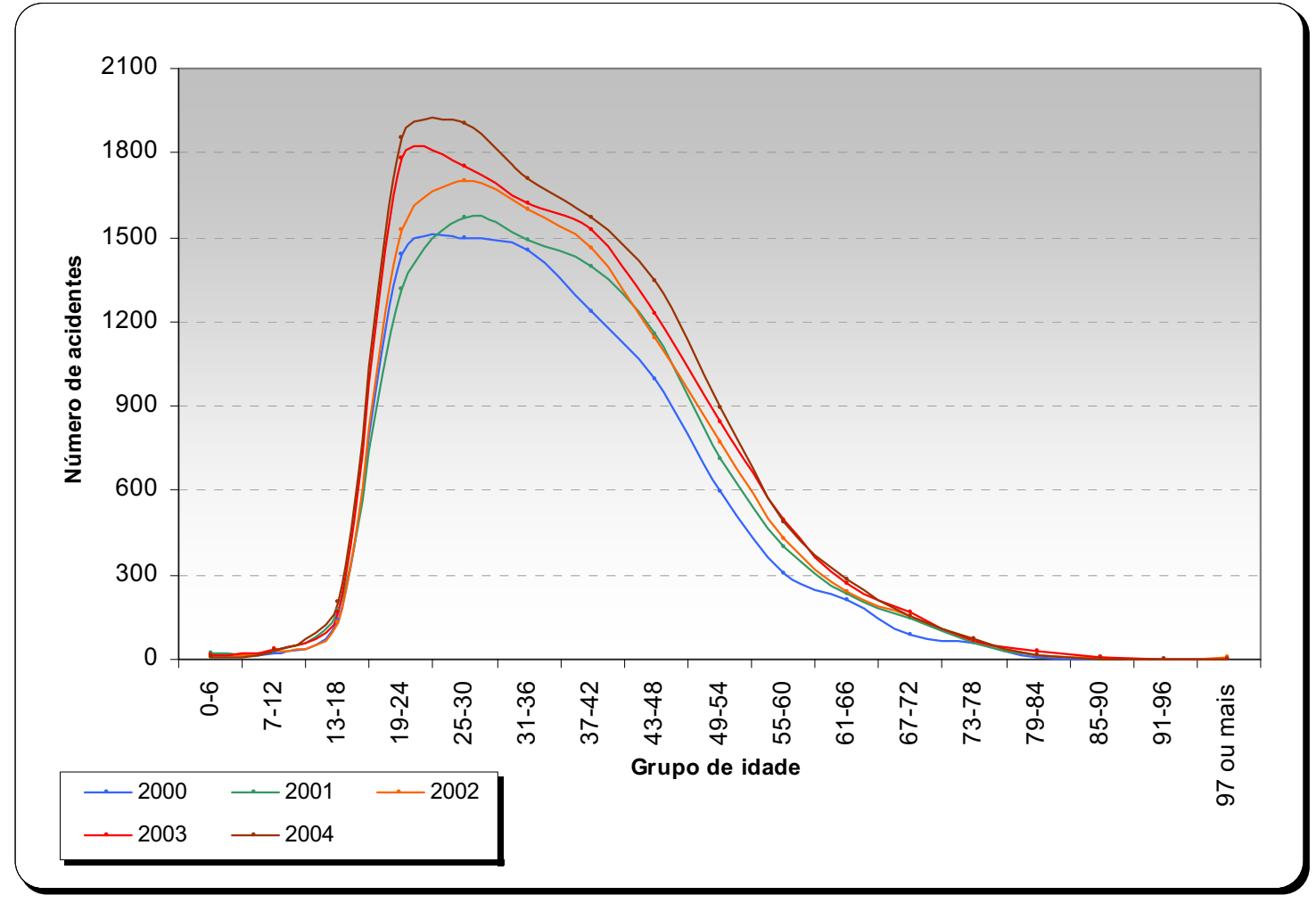

Org: Bernardino, A.R., 2006.

Fonte: SETTRAN, 2005. 
Gráfico 14 - Número de acidentes por grupos de idade dos condutores dos veículos para o sexo feminino, 2000 a 2004

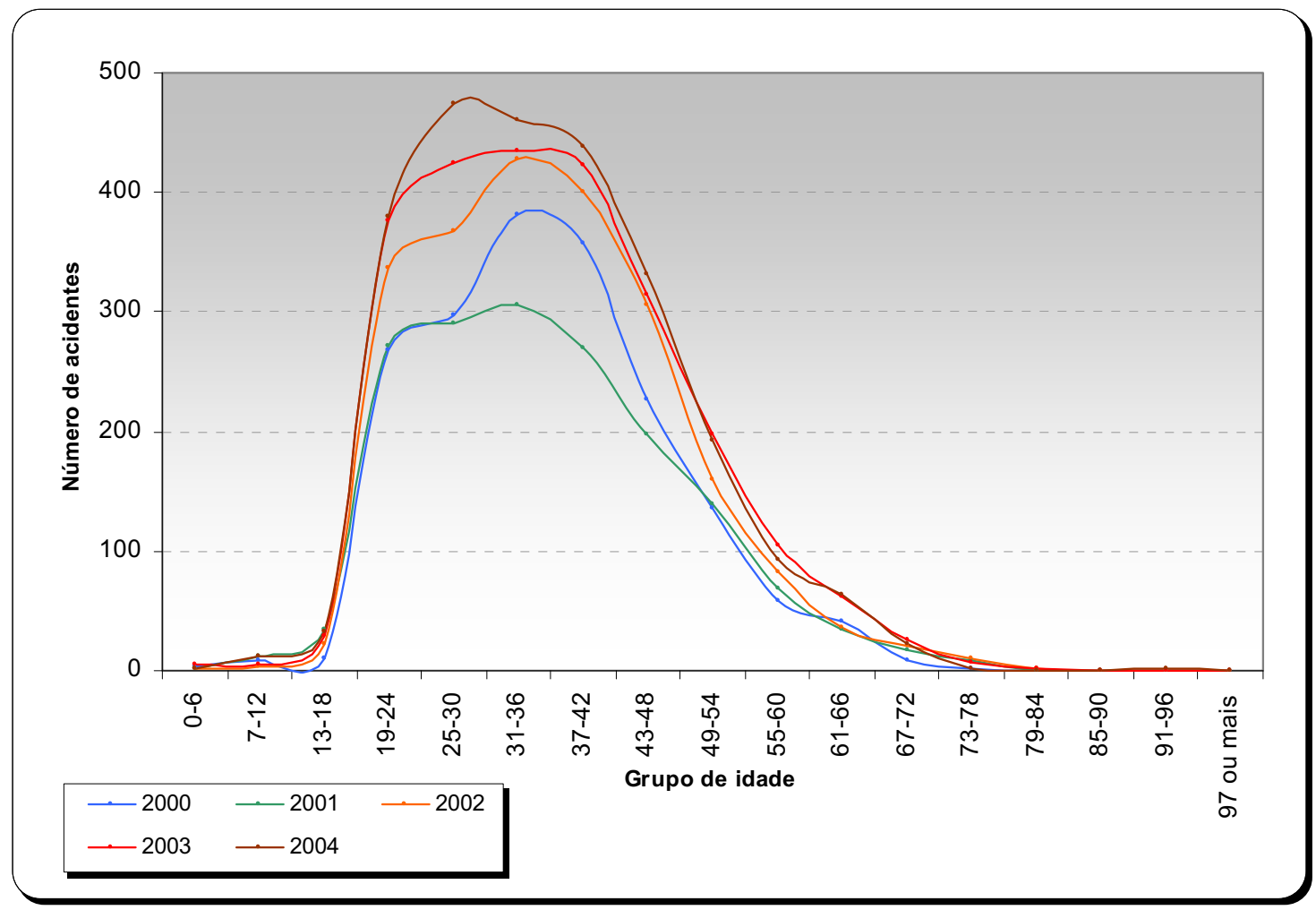

Org: Bernardino, A.R., 2006.

Fonte: SETTRAN, 2005.

Quadro 8 - Número de acidentes por grupos de idade e sexo, 2000 a 2004

\begin{tabular}{|c|c|c|c|c|c|c|c|c|c|c|}
\hline \multirow[b]{2}{*}{ IDADE/SEXO } & \multicolumn{2}{|c|}{2000} & \multicolumn{2}{|c|}{2001} & \multicolumn{2}{|c|}{2002} & \multicolumn{2}{|c|}{2003} & \multicolumn{2}{|c|}{2004} \\
\hline & $\mathrm{M}$ & $\mathrm{F}$ & M & $\mathrm{F}$ & $\mathrm{M}$ & $\mathrm{F}$ & $\mathrm{M}$ & $\mathrm{F}$ & $\mathrm{M}$ & $\mathrm{F}$ \\
\hline $0-6$ & 16 & 4 & 22 & 2 & 12 & 1 & 12 & 6 & 6 & 0 \\
\hline $7-12$ & 24 & 9 & 30 & 12 & 27 & 4 & 35 & 5 & 31 & 1 \\
\hline $13-18$ & 140 & 11 & 172 & 34 & 133 & 22 & 167 & 29 & 206 & 3 \\
\hline $19-24$ & 1441 & 268 & 1314 & 272 & 1527 & 337 & 1780 & 376 & 1853 & 23 \\
\hline $25-30$ & 1499 & 297 & 1572 & 290 & 1703 & 368 & 1752 & 424 & 1906 & 23 \\
\hline $31-36$ & 1455 & 381 & 1486 & 306 & 1599 & 428 & 1624 & 435 & 1706 & 22 \\
\hline $37-42$ & 1233 & 358 & 1394 & 270 & 1459 & 401 & 1528 & 422 & 1571 & 7 \\
\hline $43-48$ & 996 & 227 & 1156 & 198 & 1144 & 306 & 1225 & 314 & 1343 & 12 \\
\hline $49-54$ & 596 & 136 & 710 & 140 & 771 & 159 & 843 & 198 & 893 & 8 \\
\hline $55-60$ & 304 & 58 & 398 & 68 & 426 & 82 & 491 & 104 & 489 & 6 \\
\hline $61-66$ & 211 & 41 & 232 & 34 & 238 & 36 & 269 & 62 & 280 & 2 \\
\hline $67-72$ & 88 & 9 & 142 & 18 & 153 & 20 & 166 & 26 & 150 & 3 \\
\hline $73-78$ & 58 & 2 & 56 & 8 & 67 & 10 & 63 & 7 & 70 & 2 \\
\hline $79-84$ & 9 & 0 & 18 & 0 & 13 & 1 & 27 & 2 & 18 & 0 \\
\hline $85-90$ & 3 & 0 & 2 & 0 & 6 & 0 & 4 & 0 & 3 & 0 \\
\hline $91-96$ & 1 & 0 & 2 & 0 & 0 & 0 & 1 & 0 & 0 & 0 \\
\hline$>96$ & 0 & 0 & 2 & 0 & 4 & 0 & 0 & 0 & 0 & 0 \\
\hline
\end{tabular}

Legenda: M=Masculino, F=Feminino

Org: BERNARDINO, A.R., 2006.

Fonte: SETTRAN, 2005. 
De acordo com informações do DENATRAN (2003) baseadas no Registro Nacional de Condutores Habilitados (RENACH), conta-se, no Brasil, com um total de 37.144.993 condutores de veículos, sendo que, desses, $73,27 \%$ são homens e $26,73 \%$ mulheres, em que se verifica uma proporção expressiva do cidadão do sexo masculino no trânsito brasileiro.

Outro indicativo verificado, nessa variável relacionada com os grupos de idade, é que o número de mulheres condutoras de veículos envolvidos em acidentes de trânsito, na faixa de idade entre 73 a 78 anos, reduz-se expressivamente (cf. gráfico 14) em relação aos homens, os quais se restringem entre 79 e 84 anos. Acima dos 84 anos, as mínimas ocorrências registradas estão relacionadas somente com o sexo masculino (cf. quadro 8).

Referente ao tempo de habilitação dos condutores envolvidos acidentes de trânsito em relação à severidade, para todos os anos analisados (2000 a 2004), viu-se que o volume de ocorrências em destaque é para os condutores que possuem menos de 10 anos de habilitação, quer sejam para os danos materiais, feridos leves, feridos graves ou mortos (cf. gráficos 15 a 18 e quadro 9).

Gráfico 15 - Número de acidentes por tempo de habilitação dos condutores relacionados com a severidade (danos materiais), 2000 a 2004

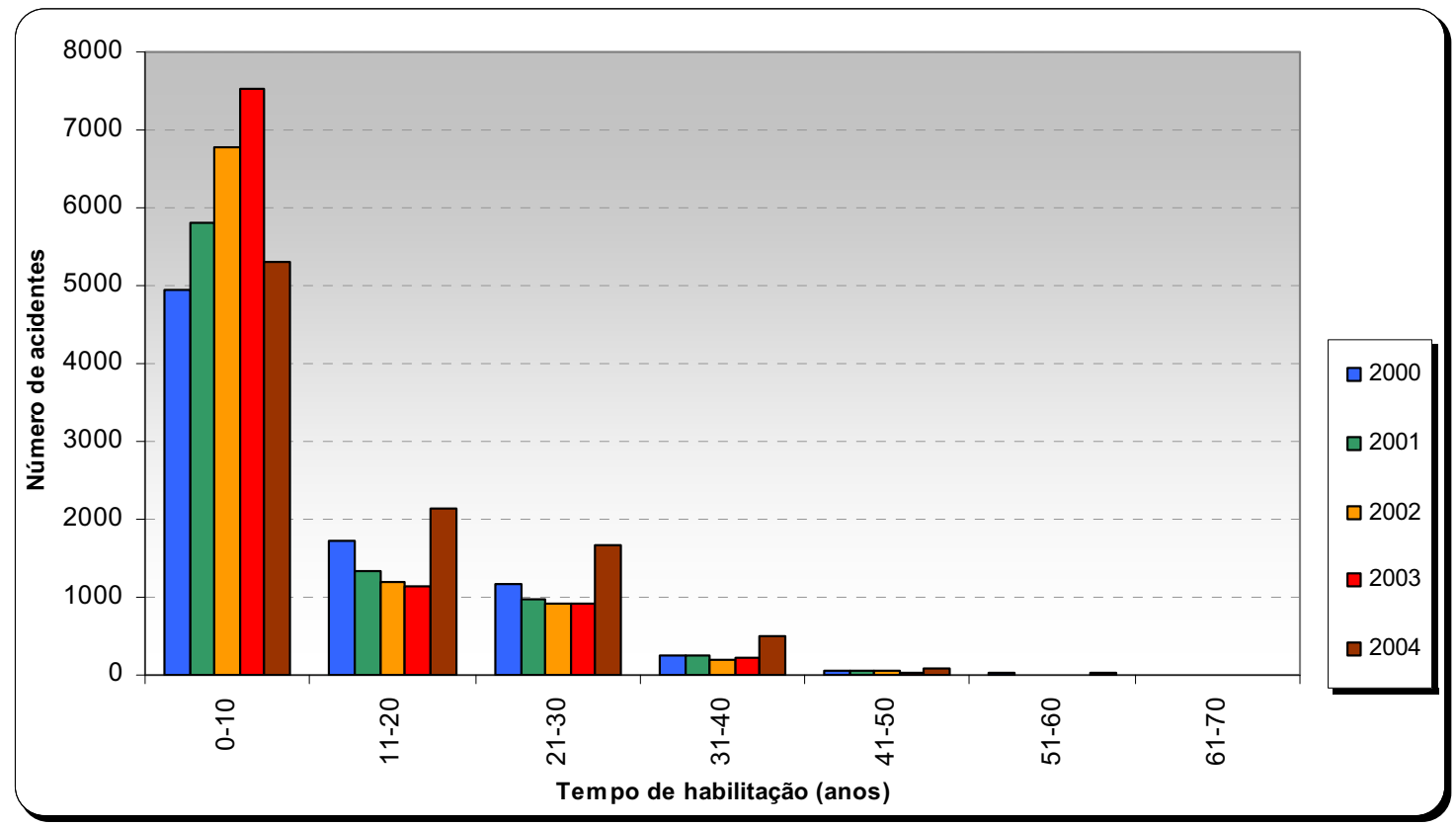

Org: Bernardino, A.R., 2006.

Fonte: SETTRAN, 2005. 
Gráfico 16 - Número de acidentes por tempo de habilitação dos condutores relacionados com a severidade (feridos leves), 2000 a 2004

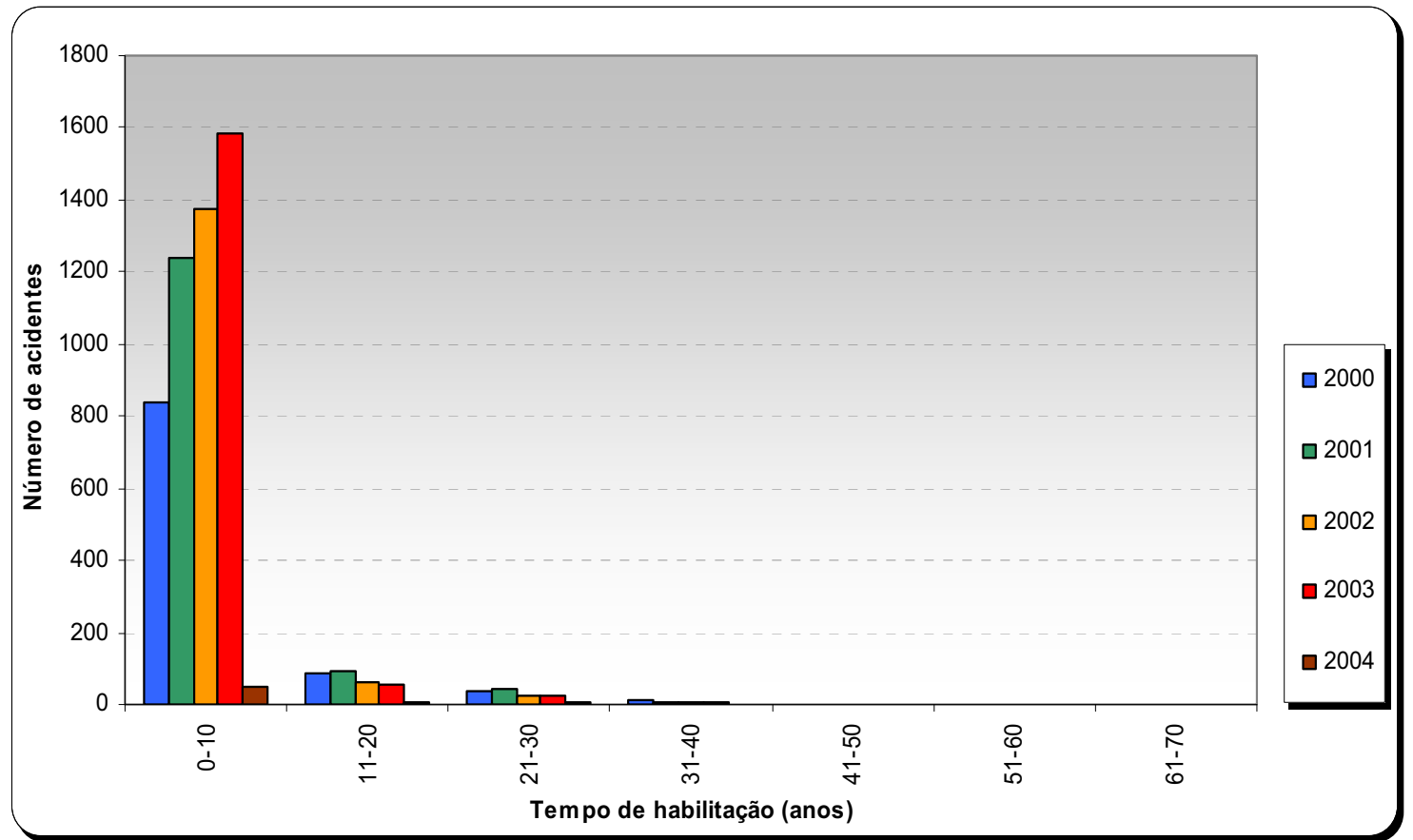

Org: Bernardino, A.R., 2006.

Fonte: SETTRAN, 2005.

Gráfico 17 - Número de acidentes por tempo de habilitação dos condutores relacionados com a severidade (feridos graves), 2000 a 2004

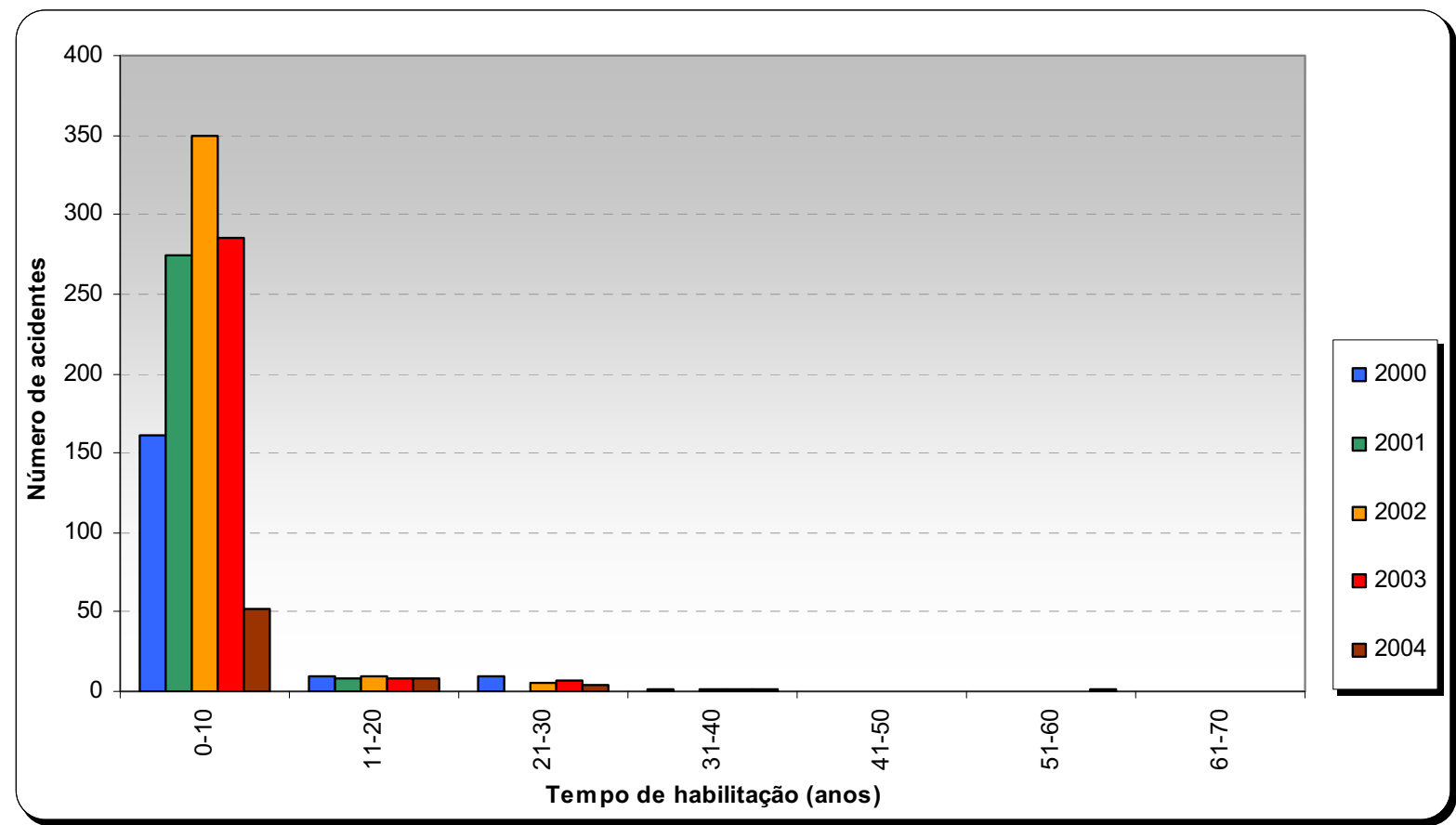

Org: Bernardino, A.R., 2006.

Fonte: SETTRAN, 2005. 
Gráfico 18 - Número de acidentes por tempo de habilitação dos condutores relacionados com a severidade (mortos), 2000 a 2004

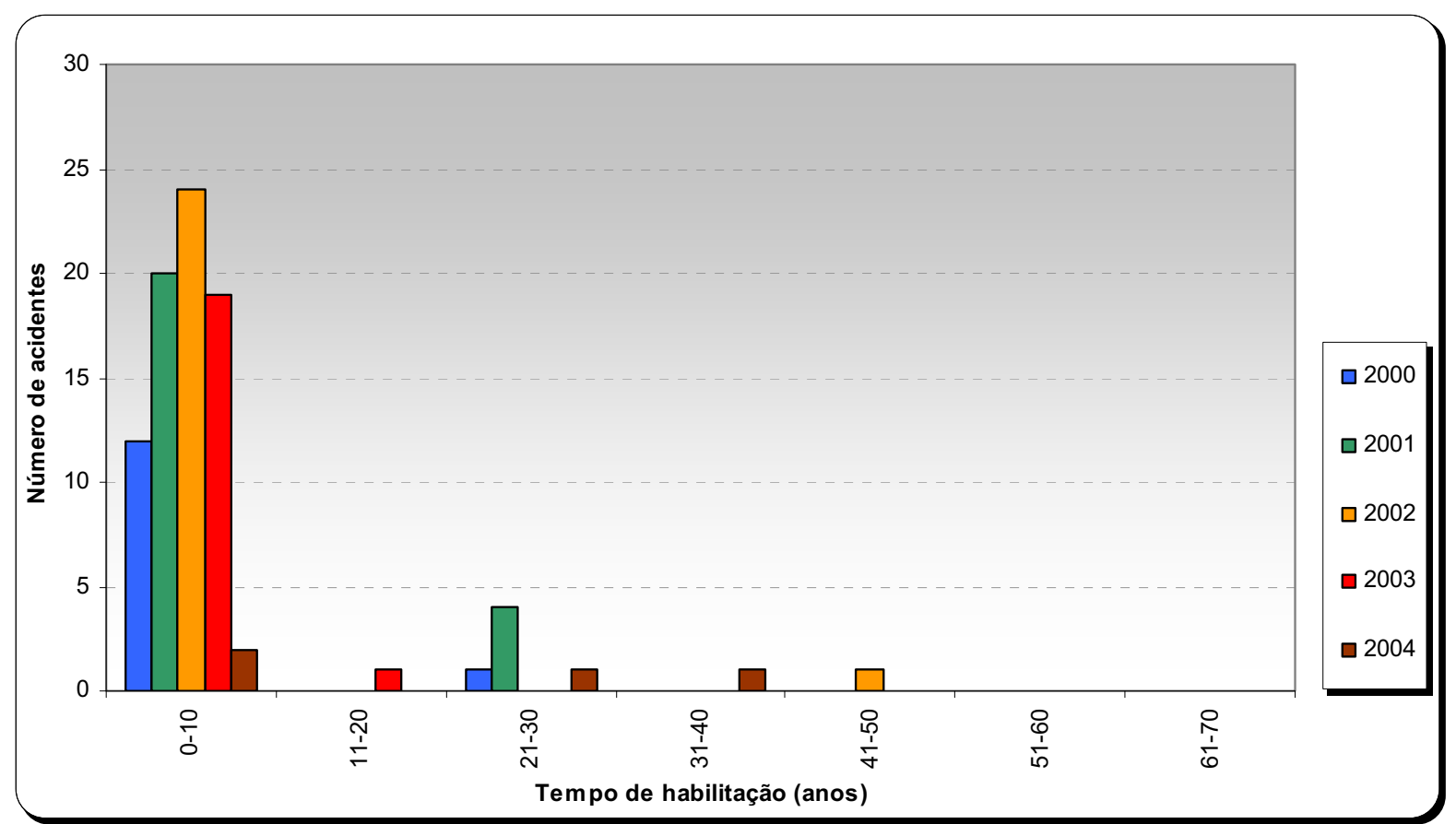

Org: Bernardino, A.R., 2006.

Fonte: SETTRAN, 2005. 


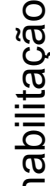

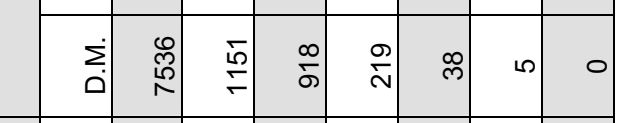

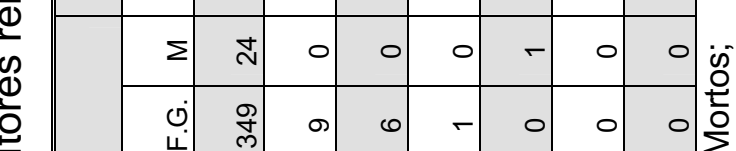

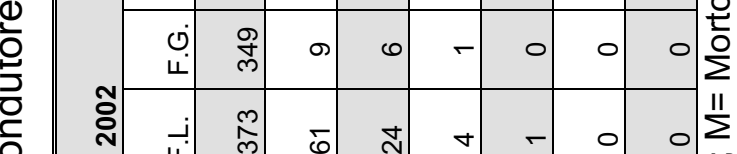

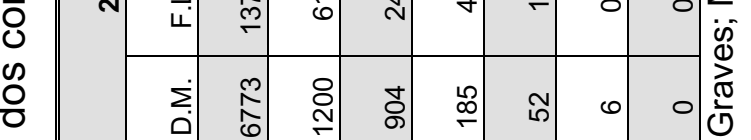

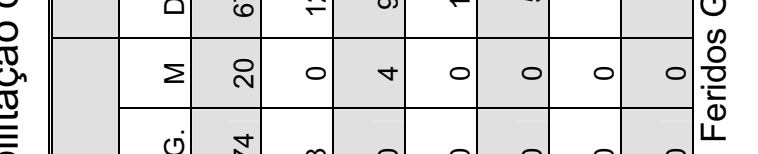

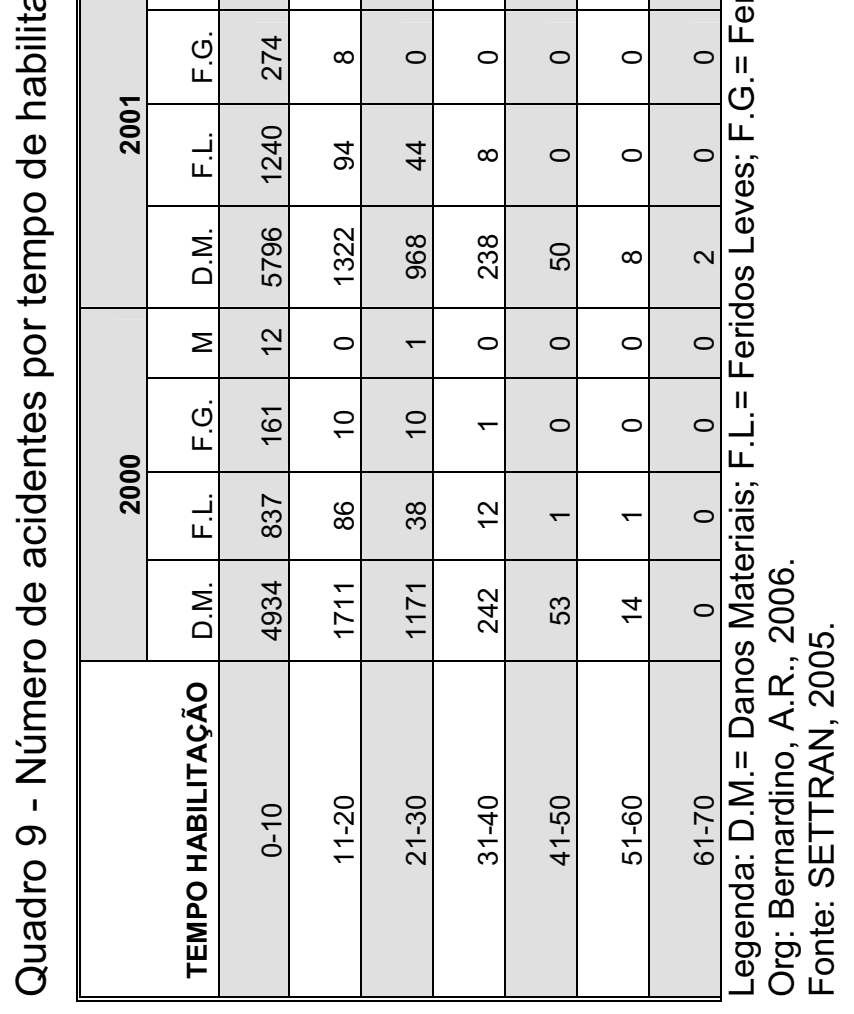

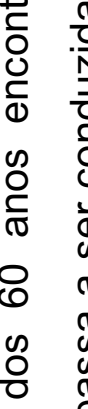

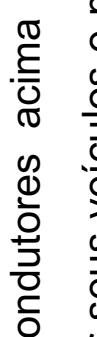

Oे

๑) 응 \&

중

음

$\frac{0}{0} \frac{0}{0} \cdot \frac{\pi}{9}$

(

(1) 즌 $\frac{0}{0}$

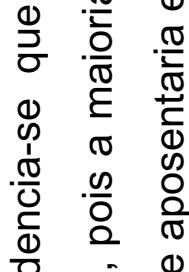

के

ш 
3.1.4 - Distribuição temporal dos acidentes: hora, dia, mês e ano

Para a análise da distribuição temporal dos acidentes de trânsito selecionaram-se as variáveis de faixa de horários relacionados a todos os dias da semana, quais sejam: domingo, segundas, terças, quartas, quintas, sextasfeiras e sábados, além de detalhar os meses e os anos, visando a uma análise mais transparente sobre a distribuição dos acidentes, considerando o tempo em suas horas, dias, meses e ano.

A distribuição horária dos acidentes registrados nos anos de 2000 a 2004 pode ser vista no gráfico 19, em que o maior volume de ocorrências encontra-se das 7 as 19 horas. O pico de ocorrências, neste período, verificouse entre 11 e 17 horas, principalmente para os acidentes com danos materiais (cf. gráfico 20).

Gráfico 19 - Número de acidentes por horários, 2000 a 2004.

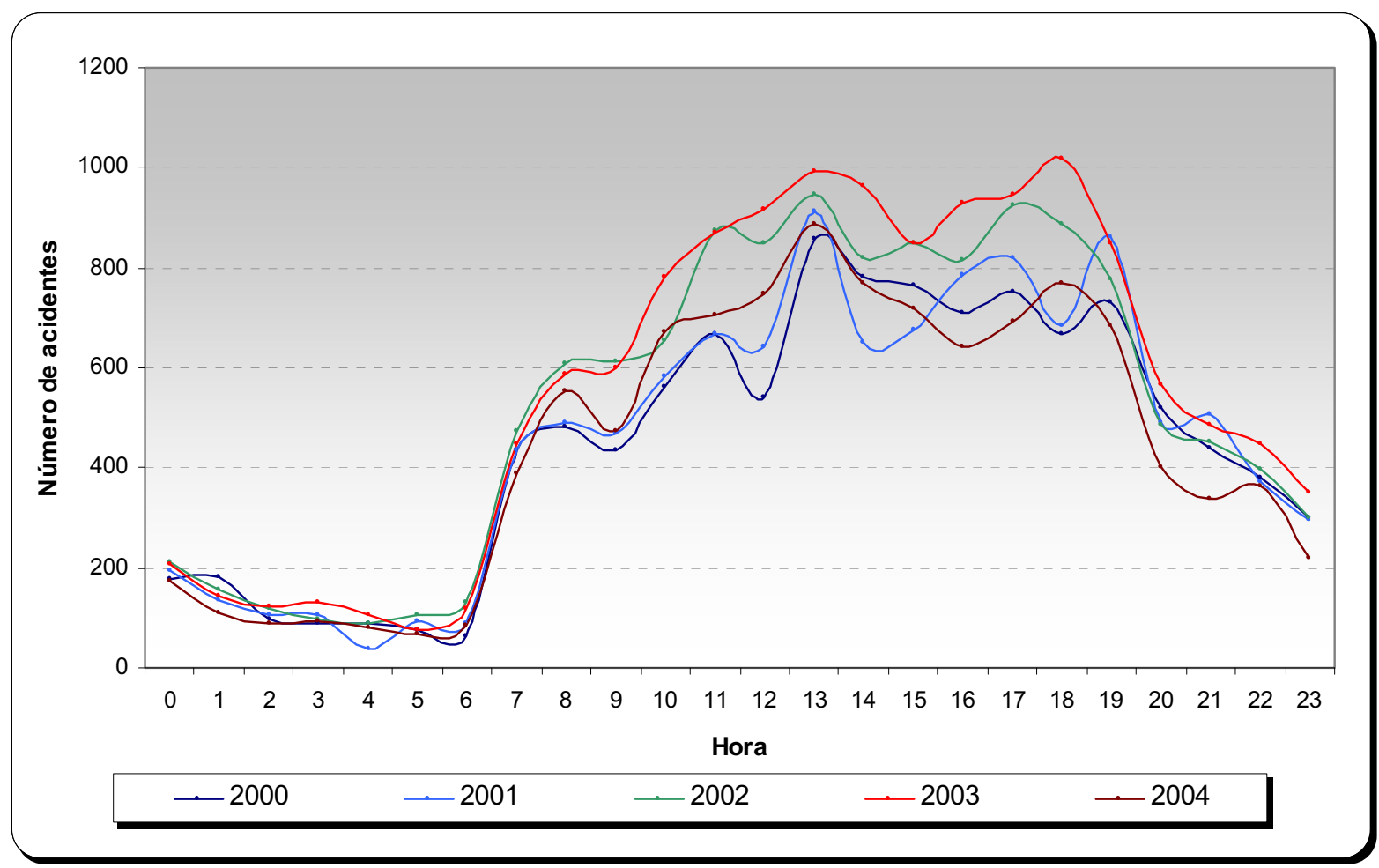

Org: Bernardino, A.R., 2006.

Fonte: SETTRAN, 2005. 
Os gráficos 20 a 23 apresentam os dados dos acidentes a respeito da faixa de horários por severidade, sendo que a distribuição das horas para as severidades "danos materiais" e "feridos leves" dos registros dos acidentes seguiu, aproximadamente, as horas entre 7 e 19 horas, com picos de ocorrências entre 11 e 17 horas.

Verifica-se um grande número de ocorrências dos acidentes referente à severidade "danos materiais" (cf. gráfico 20 e quadro 10). Este fato pode ser relacionado com os horários de maior fluxo de veículos e pedestres, que se aglomeram, vez por outras, nas áreas atrativas e centros comerciais e de serviços das cidades, onde os transeuntes se encontram quando em suas atividades diárias.

Gráfico 20 - Número de acidentes por horários quanto à severidade (danos materiais), 2000 a 2004.

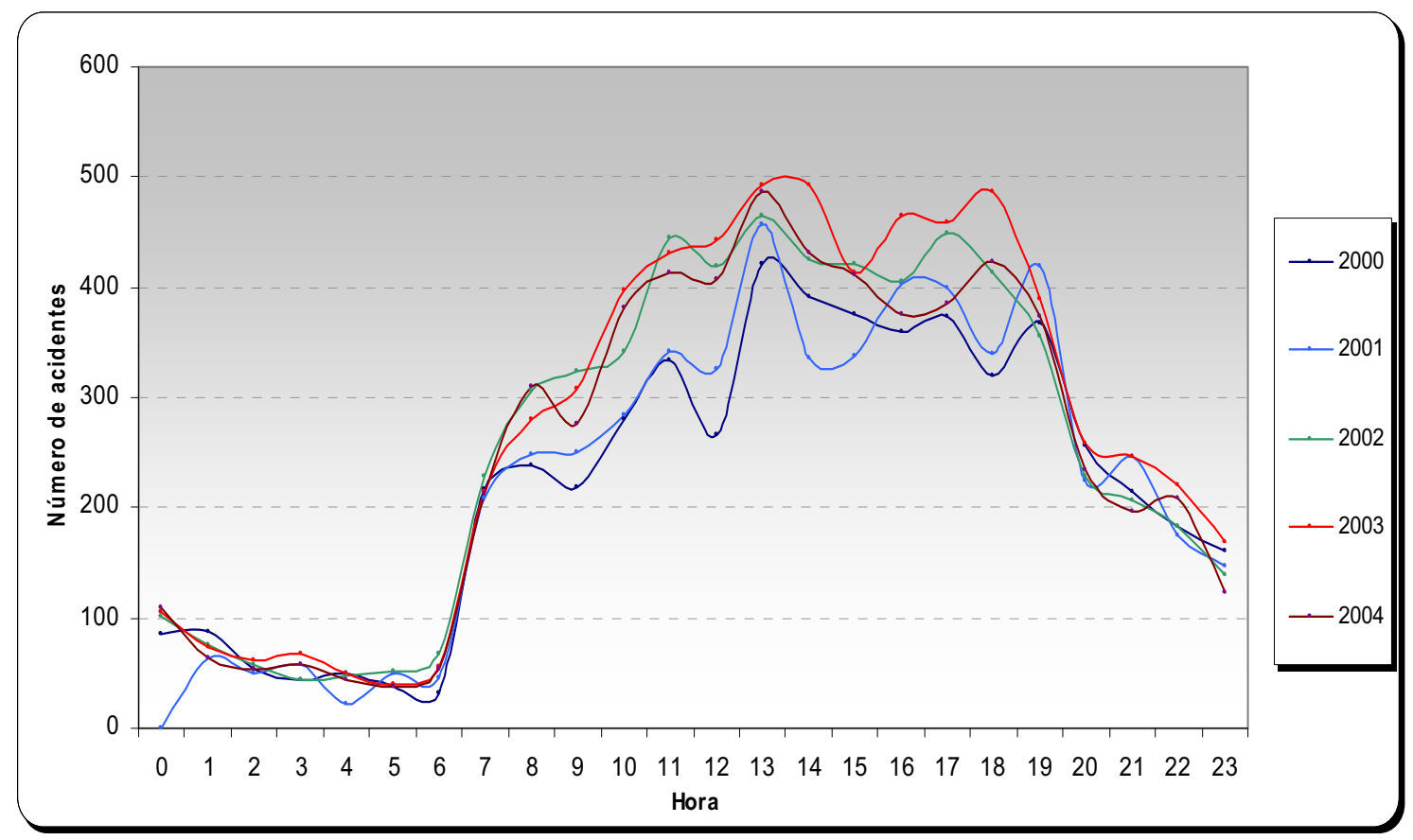

Org: BERNARDINO, A.R., 2006.

Fonte: SETTRAN, 2005.

Sobre a freqüência anual dos horários de ocorrência dos acidentes, observa-se que as severidades "feridos leves" e "feridos graves", para os anos de 2000 a 2004, foram crescentes, porém a distribuição dos acidentes, em 
2004, em relação aos outros anos, reduziu-se em volume nesses dois atributos, assim considerando que as ocorrências estejam distribuídas por um período de horas mais longo durante o dia (cf. gráficos 21 e 22 e quadro 10).

Gráfico 21 - Número de acidentes por horários quanto à severidade (feridos leves), 2000 a 2004.

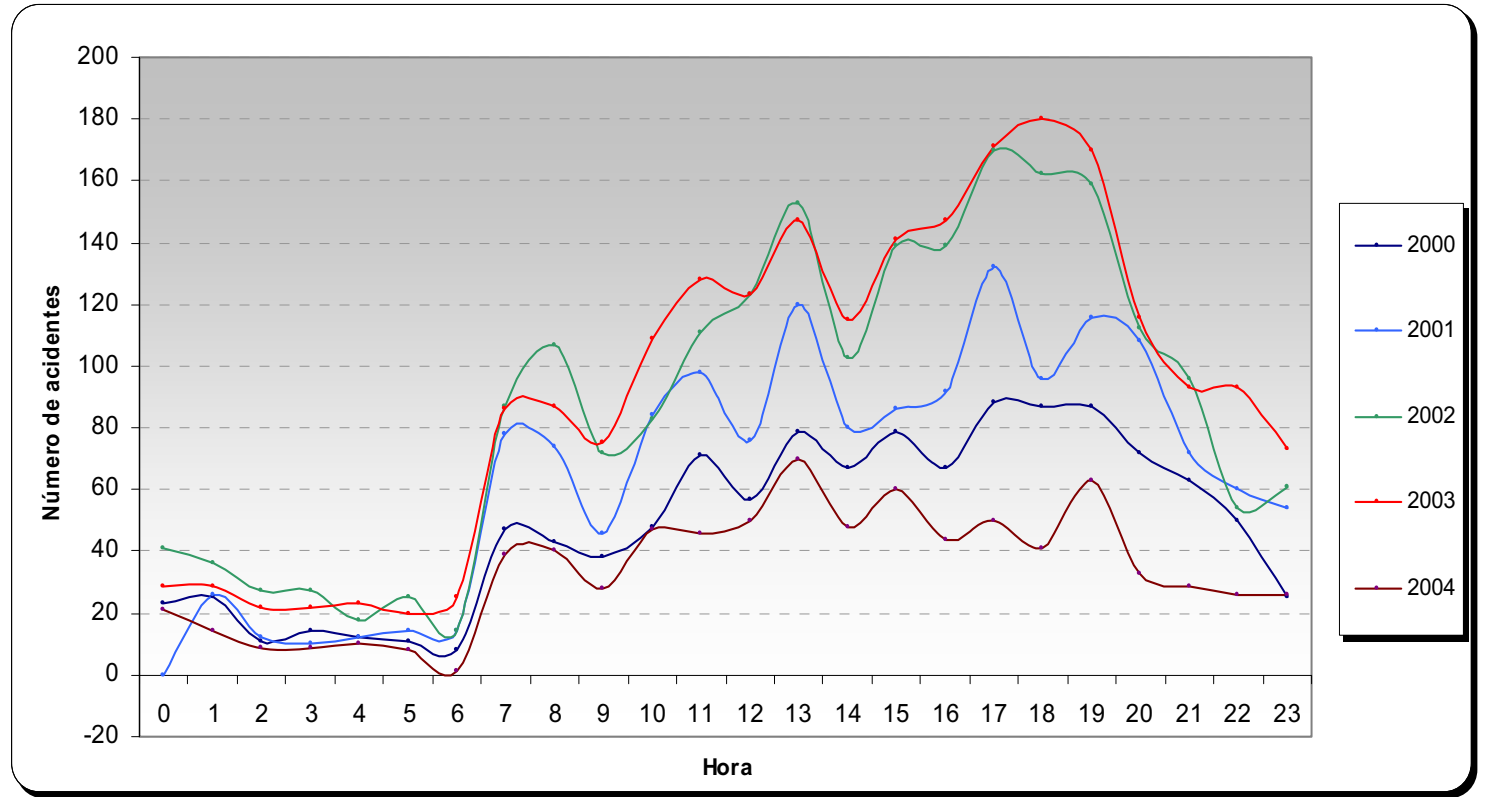

Org: BERNARDINO, A.R., 2006.

Fonte: SETTRAN, 2005.

Gráfico 22 - Número de acidentes por horários quanto à severidade (feridos graves), 2000 a 2004.

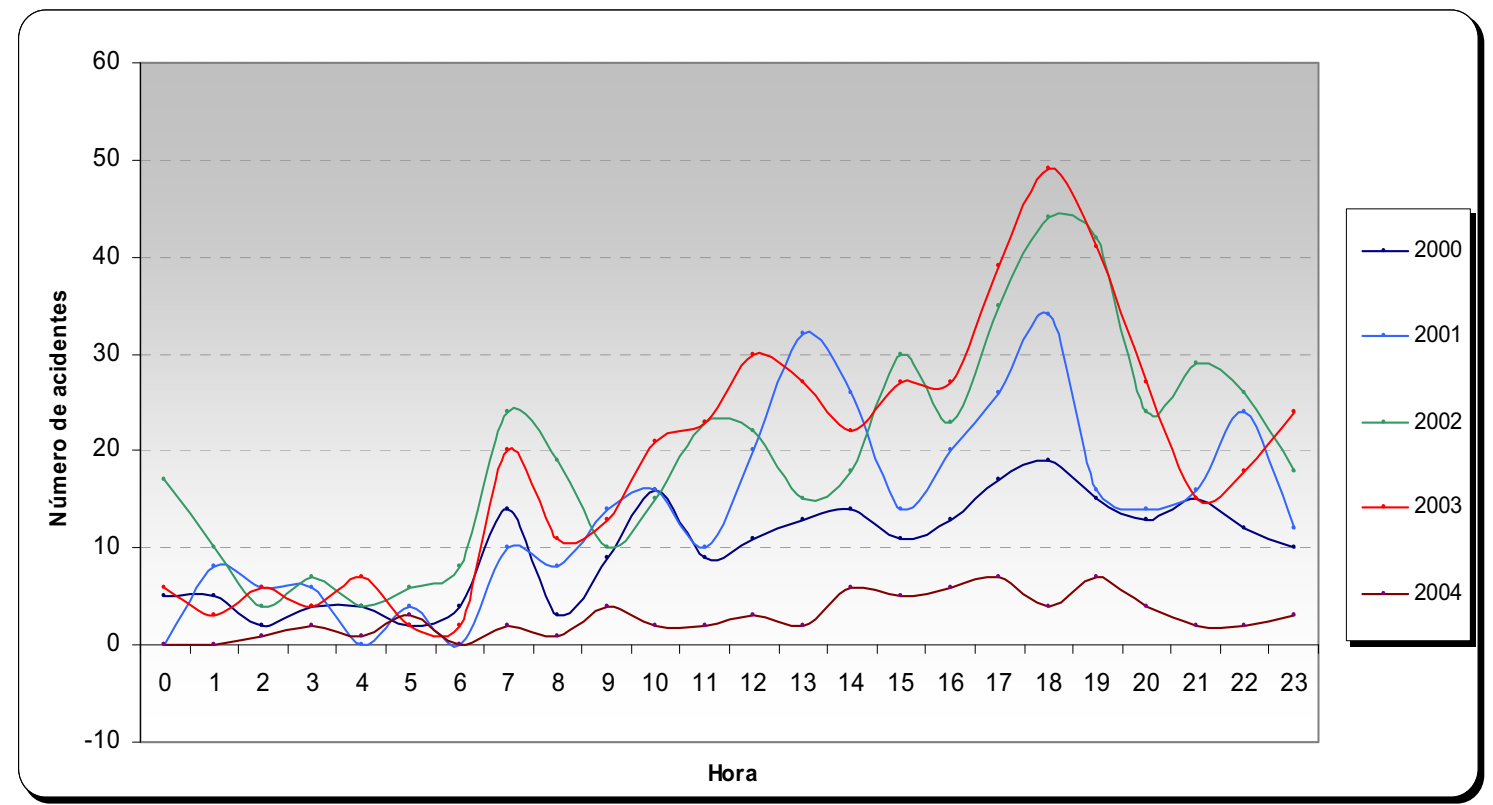

Org: BERNARDINO, A.R., 2006.

Fonte: SETTRAN, 2005. 
Para os acidentes com feridos graves (cf. gráfico 22), nota-se que, à medida que vai anoitecendo, os acidentes ocorridos relacionam-se à gravidade mais severa, com exceção da variável "mortos", que não possibilita esta análise por horários.

$\mathrm{Na}$ apresentação dos resultados da severidade mortos relacionados com horários de ocorrência dos acidentes, este atributo não revelou uma continuidade ou mesmo freqüência que possa ser detalhada. Como ponto positivo neste atributo "mortos", pode-se considerar que os acidentes de trânsito com vitimas fatais não apresentaram continuidade nas ocorrências registradas, pois não tiveram seus horários de acontecimentos dispostos em grupos e com uma freqüência que permitisse observar seqüência ou verossimilhança com os horários de ocorrência entre os anos pesquisados (cf. gráfico 23).

Gráfico 23 - Número de acidentes por horários quanto à severidade (mortos), 2000 a 2004.

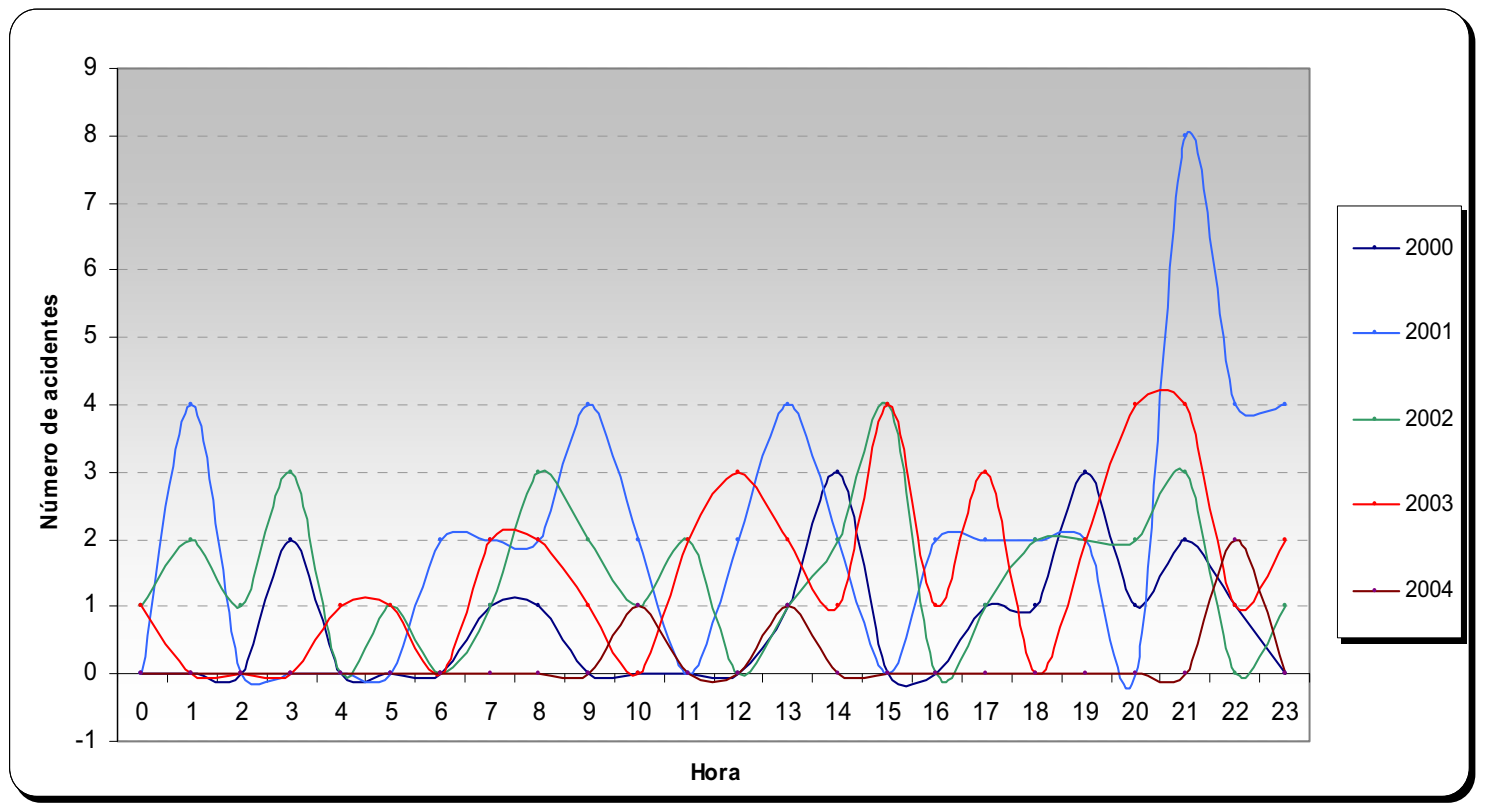

Org: BERNARDINO, A.R., 2006.

Fonte: SETTRAN, 2005.

Salienta-se que a gravidade dos acidentes nos Boletins de Ocorrência, considerando os danos materiais, feridos leves, feridos graves e mortos é aquela identificada quando do preenchimento do formulário, de levantar os dados sobre o acidente, pelo policial ou agente de trânsito. 


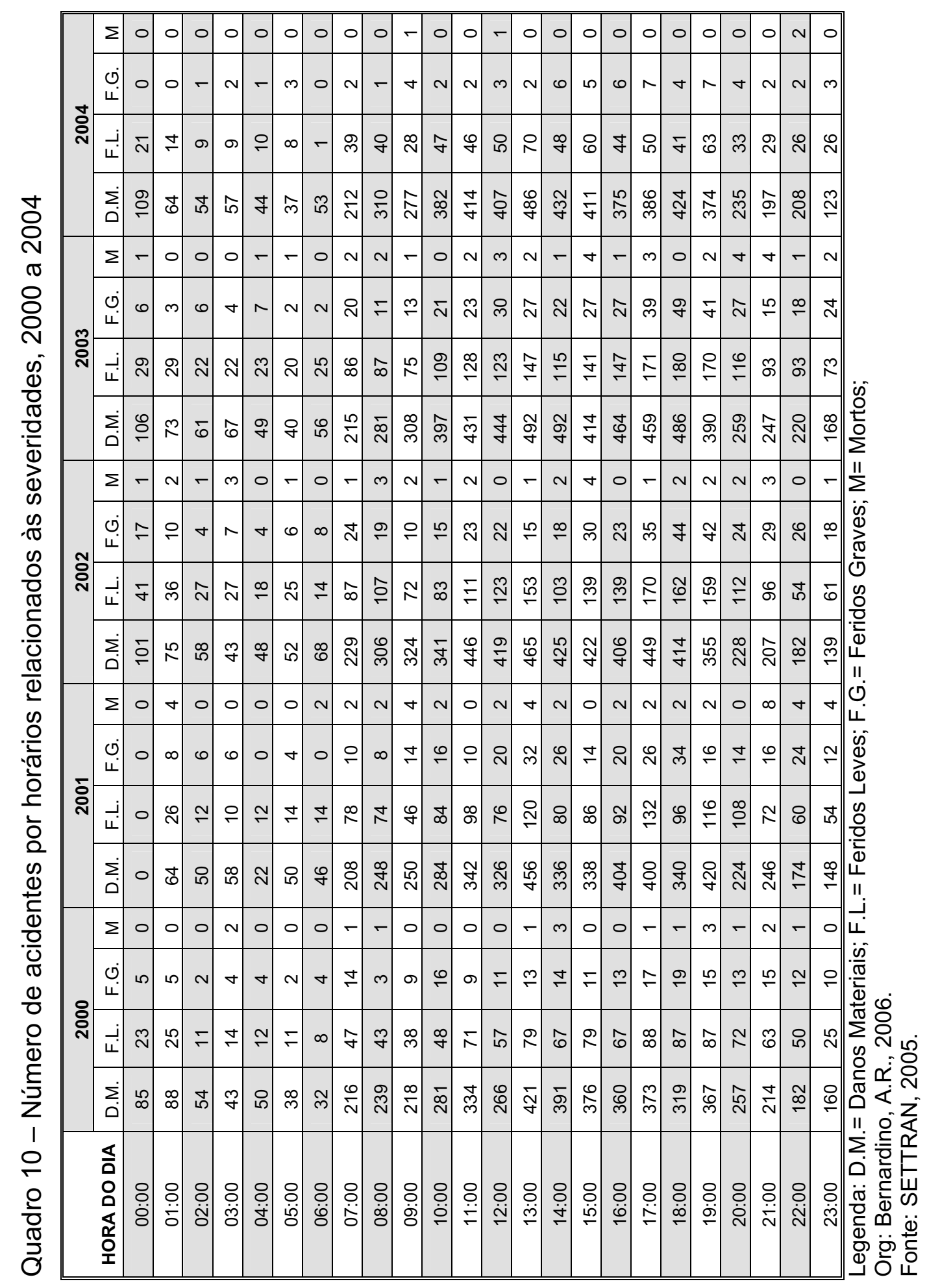


Acrescenta-se, ainda, que, na ocasião de um acidente com vítima(s) fatal(is), a importância é de resgate e possível reversão da situação do evento, ficando o preenchimento do formulário em segundo lugar.

Isso pode ser verificado em dados de outras fontes sobre os óbitos ocorridos por acidentes de trânsito, como no quadro abaixo; as informações obtidas por meio do DATASUS, 2006.

Quadro 11 - Número de óbitos em acidentes de trânsito, 2000 a 2004 Uberlândia

\begin{tabular}{||c|c|c||}
\hline Ano & DATASUS & B.O. (Polícia Militar e SETTRAN) \\
\hline 2004 & 127 & 38 \\
\hline 2003 & 124 & 38 \\
\hline 2002 & 126 & 35 \\
\hline 2001 & 88 & 16 \\
\hline 2000 & 51 & 17 \\
\hline
\end{tabular}

Org: BERNARDINO, A. R., 2006

A importância dessa discussão é também relacionada com a severidade "mortos", principalmente, porquanto, em muitas situações em que haja vítimas, com ferime ntos leves ou graves, pode vir a ocorrer o óbito imediatamente após o acidente ou até após 30 dias de internação nos hospitais, sendo um fator a mais para a inconsistência dos dados e de número absolutos literalmente.

Os números dos acidentes de trânsito, por mês para o ano de 2000 (cf. gráfico 24 e quadro 12), relacionados com o dia da semana de maior número de eventos foram: aos sábados, as ocorrências para os meses de fevereiro, abril, junho e outubro apresentaram os maiores números registrados de acidentes; na sexta-feira, os meses de março, setembro e dezembro; na quinta-feira, os meses de maio e novembro; na quarta-feira o mês de agosto; e na segunda-feira os meses de janeiro e julho expuseram os números mais altos das ocorrências de acidentes de trânsito. 
Gráfico 24 - Número de acidentes por mês para todos os dias da semana, 2000

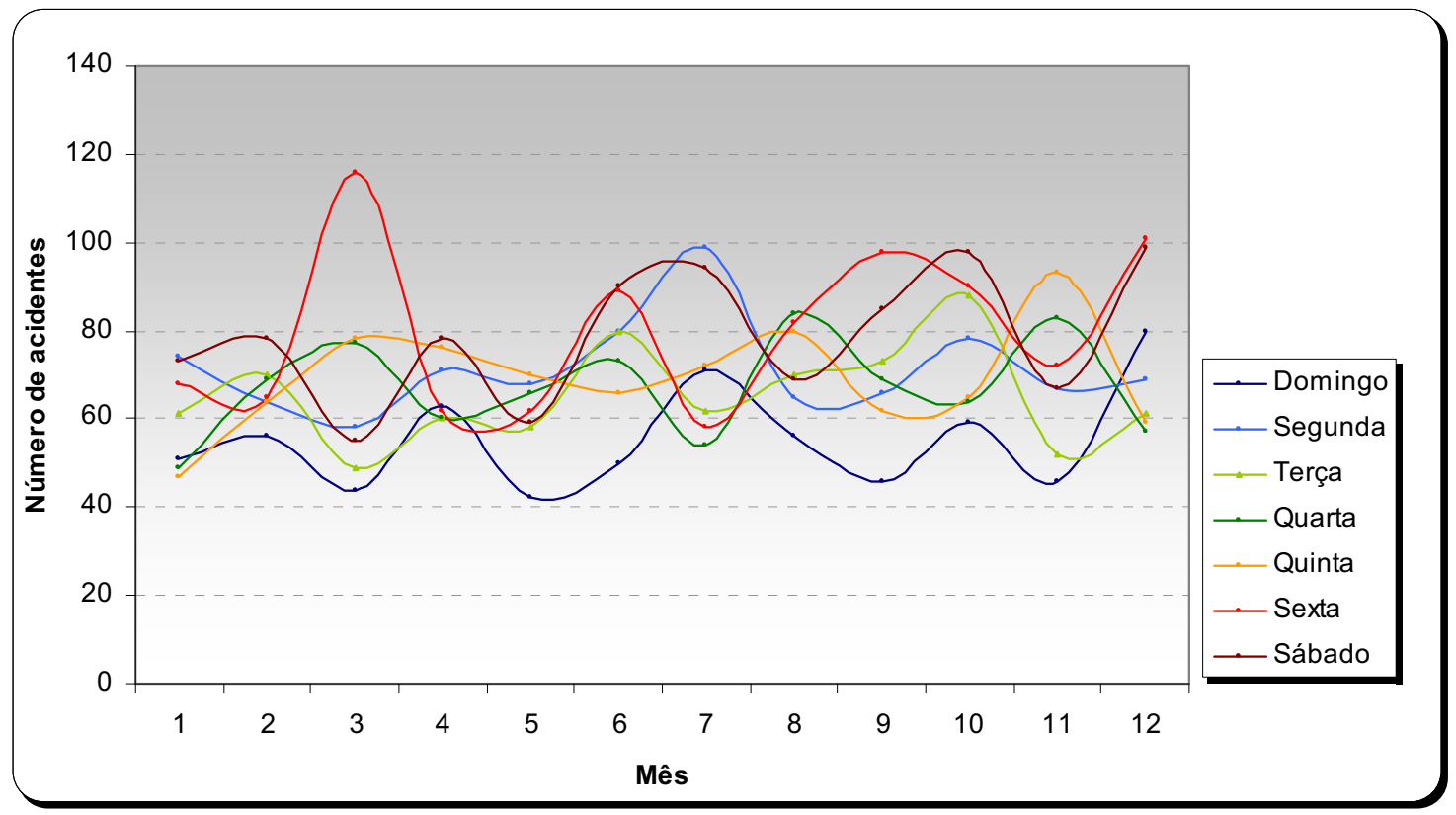

Org: BERNARDINO, A.R., 2006.

Fonte: SETTRAN, 2005.

Quadro 12 - Número de acidentes por mês para todos os dias da semana, 2000

\begin{tabular}{|c|c|c|c|c|c|c|c|}
\hline \hline Mês/Dia da Semana & Domingo & Segunda & Terça & Quarta & Quinta & Sexta & Sábado \\
\hline Janeiro & 51 & 74 & 61 & 49 & 47 & 68 & 73 \\
\hline Fevereiro & 56 & 64 & 70 & 69 & 64 & 65 & 78 \\
\hline Março & 44 & 58 & 49 & 77 & 78 & 116 & 55 \\
\hline Abril & 63 & 71 & 60 & 60 & 76 & 62 & 78 \\
\hline Maio & 42 & 68 & 58 & 66 & 70 & 62 & 59 \\
\hline Junho & 50 & 80 & 80 & 73 & 66 & 89 & 90 \\
\hline Julho & 71 & 99 & 62 & 54 & 72 & 58 & 94 \\
\hline Agosto & 56 & 65 & 70 & 84 & 80 & 82 & 69 \\
\hline Setembro & 46 & 66 & 73 & 69 & 62 & 98 & 85 \\
\hline Outubro & 59 & 78 & 88 & 64 & 65 & 90 & 98 \\
\hline Novembro & 46 & 67 & 52 & 83 & 93 & 72 & 67 \\
\hline Dezembro & 80 & 69 & 61 & 57 & 59 & 101 & 99 \\
\hline
\end{tabular}

Legenda: $00=$ número maior de acidentes por dia da semana Org: BERNARDINO, A.R., 2006.

Fonte: SETTRAN, 2005.

Os números dos acidentes de trânsito por mês para o ano de 2001 (cf. gráfico 25 e quadro 13, relacionados com o dia da semana com maior número de eventos foram; aos sábados, com ocorrências para os meses de março, junho, agosto, setembro e dezembro, os quais apresentaram os maiores números registrados. Na sexta-feira, os meses de maior número de ocorrências foram maio e novembro; na quarta-feira, o meses de janeiro e fevereiro; na 
terça-feira, os meses de abril e julho; na segunda-feira, o mês de outubro com os números maiores de ocorrências de acidentes de trânsito.

Gráfico 25 - Número de acidentes por mês para todos dias da semana, 2001

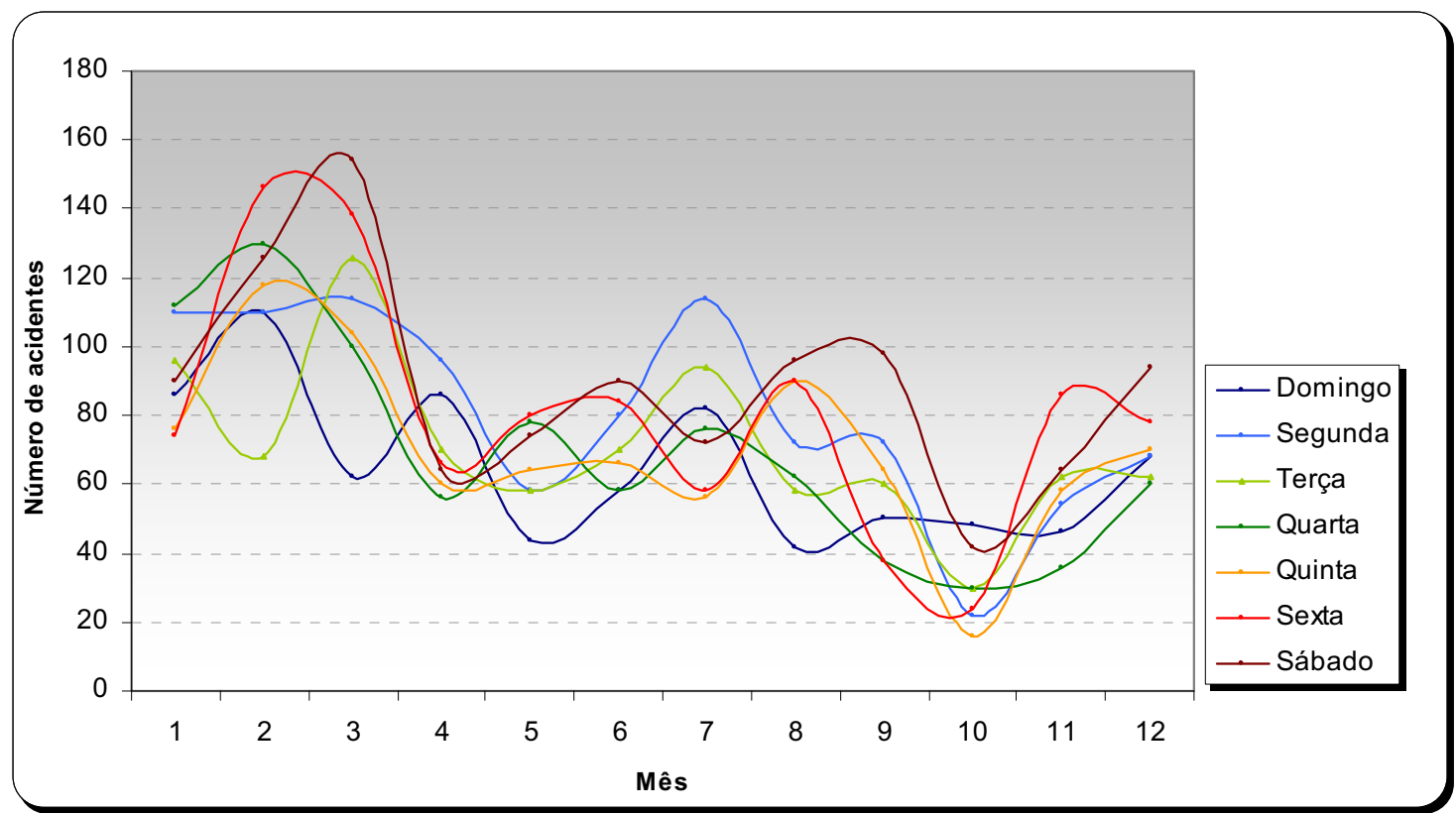

Org: BERNARDINO, A.R., 2006.

Fonte: SETTRAN, 2005.

Quadro 13 - Número de acidentes por mês para todos os dias da semana, 2001

\begin{tabular}{||c|c|c|c|c|c|c|c||}
\hline \hline Mês/Dia Semana & Domingo & Segunda & Terça & Quarta & Quinta & Sexta & Sábado \\
\hline Janeiro & 86 & 110 & 96 & 112 & 76 & 74 & 90 \\
\hline Fevereiro & 110 & 110 & 68 & 130 & 118 & 146 & 126 \\
\hline Março & 62 & 114 & 126 & 100 & 104 & 138 & 154 \\
\hline Abril & 86 & 96 & 70 & 56 & 60 & 66 & 64 \\
\hline Maio & 44 & 58 & 58 & 78 & 64 & 80 & 74 \\
\hline Junho & 58 & 80 & 70 & 58 & 66 & 84 & 90 \\
\hline Julho & 82 & 114 & 94 & 76 & 56 & 58 & 72 \\
\hline Agosto & 42 & 72 & 58 & 62 & 90 & 90 & 96 \\
\hline Setembro & 50 & 72 & 60 & 38 & 64 & 38 & 98 \\
\hline Outubro & 48 & 22 & 30 & 30 & 16 & 24 & 42 \\
\hline Novembro & 46 & 54 & 62 & 36 & 58 & 86 & 64 \\
\hline Dezembro & 68 & 68 & 62 & 60 & 70 & 78 & 94 \\
\hline \hline
\end{tabular}

Legenda: $00=$ número maior de acidentes por dia da semana

Org: BERNARDINO, A.R., 2006.

Fonte: SETTRAN, 2005.

Os números dos acidentes de trânsito por mês para o ano de 2002 (cf. gráfico 26 e quadro 14), relacionados com o dia da semana de maior número de eventos demonstraram que, aos sábados, as ocorrências, para os meses de junho e novembro, apresentaram-se os maiores números registrados; na sextafeira, os meses de fevereiro, março, maio, agosto e setembro; na quinta-feira 
os meses de janeiro e outubro; na quarta-feira, o mês de julho; na segundafeira os meses de abril e dezembro mostraram os mais elevados números de ocorrências de acidentes de trânsito registradas.

Gráfico 26 - Número de acidentes por mês para todos dias da semana, 2002

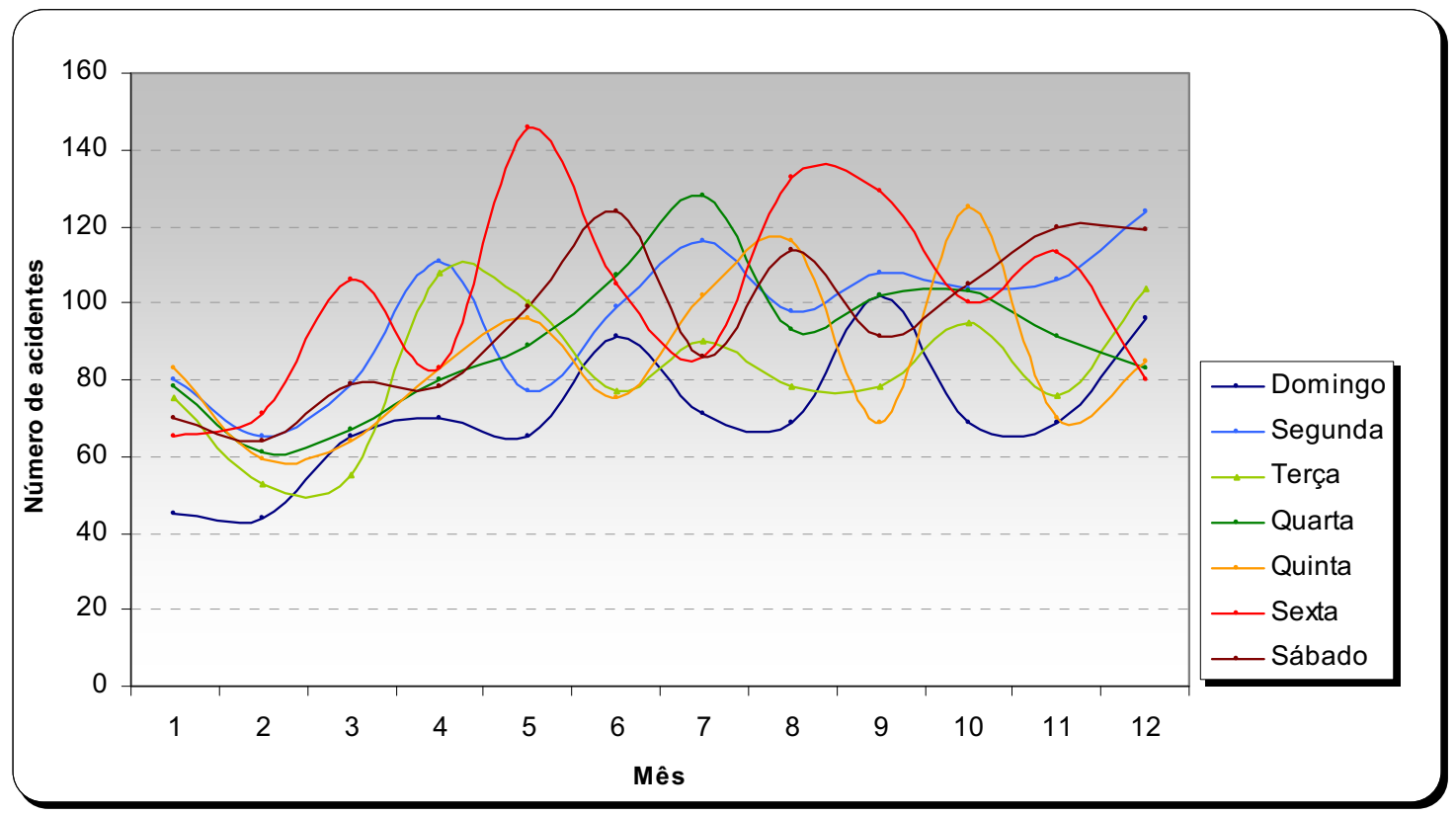

Org: BERNARDINO, A.R., 2006.

Fonte: SETTRAN, 2005.

Quadro 14 - Número de acidentes por mês para todos os dias da semana, 2002

\begin{tabular}{|c|c|c|c|c|c|c|c|}
\hline Mês/Dia Semana & Domingo & Segunda & Terça & Quarta & Quinta & Sexta & Sábado \\
\hline Janeiro & 45 & 80 & 75 & 78 & 83 & 65 & 70 \\
\hline Fevereiro & 44 & 65 & 53 & 61 & 59 & 71 & 64 \\
\hline Março & 65 & 79 & 55 & 67 & 64 & 106 & 79 \\
\hline Abril & 70 & 111 & 108 & 80 & 83 & 83 & 78 \\
\hline Maio & 65 & 77 & 100 & 89 & 96 & 146 & 99 \\
\hline Junho & 91 & 99 & 77 & 107 & 75 & 105 & 124 \\
\hline Julho & 71 & 116 & 90 & 128 & 102 & 86 & 86 \\
\hline Agosto & 69 & 98 & 78 & 93 & 116 & 133 & 114 \\
\hline Setembro & 102 & 108 & 78 & 102 & 69 & 129 & 91 \\
\hline Outubro & 69 & 104 & 95 & 103 & 125 & 100 & 105 \\
\hline Novembro & 69 & 106 & 76 & 91 & 70 & 113 & 120 \\
\hline Dezembro & 96 & 124 & 104 & 83 & 85 & 80 & 119 \\
\hline
\end{tabular}

Legenda: 00=número maior de acidentes por dia da semana

Org: Bernardino, A.R., 2006.

Fonte: SETTRAN, 2005.

Os números dos acidentes de trânsito por mês para o ano de 2003 (cf. gráfico 27 e quadro 15), relacionados com o dia da semana de maior número de eventos, demonstraram os dias de sábados, para os meses de março, agosto e novembro, com os maiores números registrados; na sexta-feira, os 
meses de janeiro, fevereiro e maio; na quinta-feira, o mês de outubro; na quarta-feira, os meses de abril e julho; na segunda-feira, o meses de junho, setembro e dezembro tiveram números maiores de ocorrências de acidentes de trânsito.

Gráfico 27 - Número de acidentes por mês para todos dias da semana, 2003

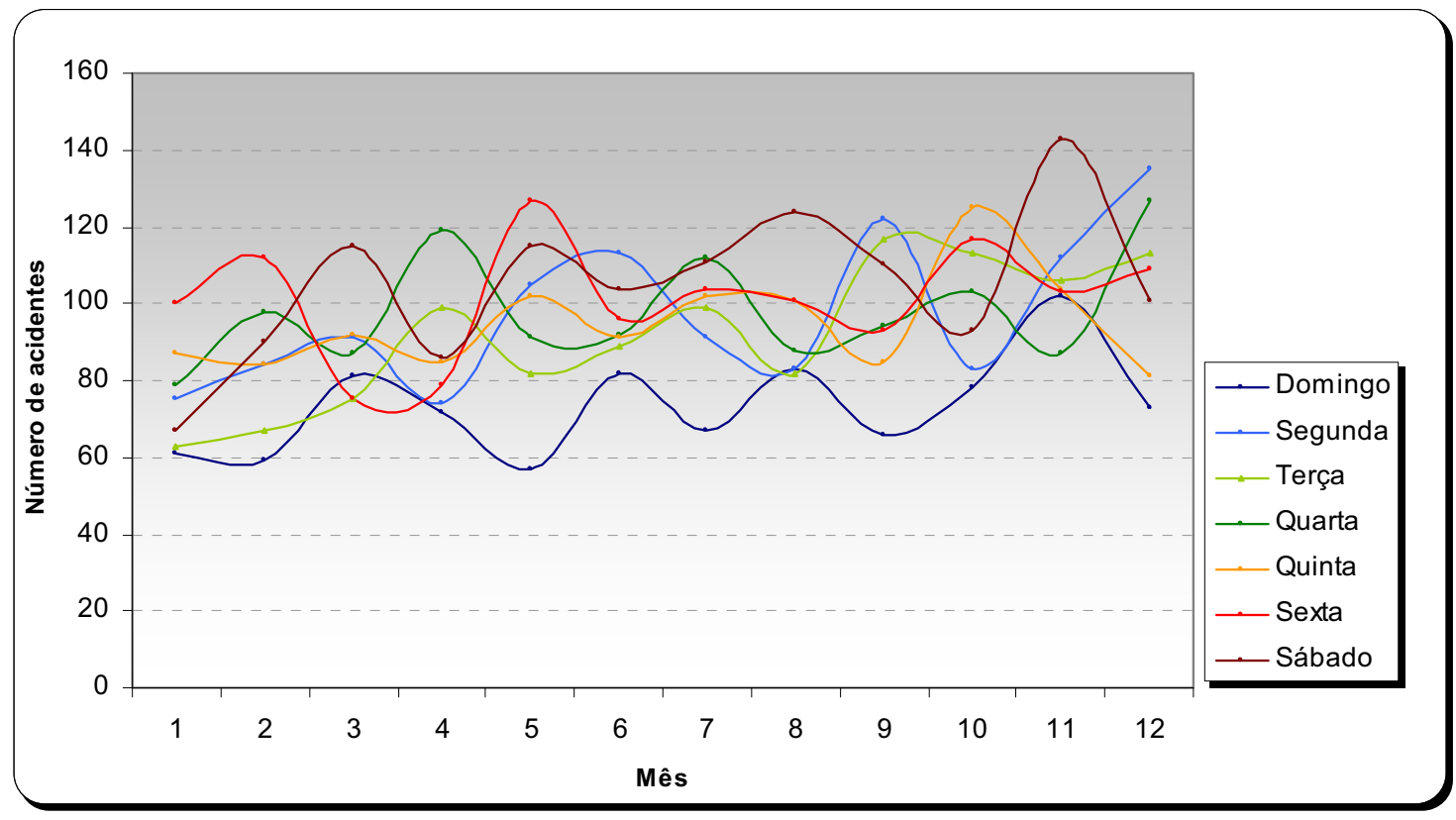

Org: BERNARDINO, A.R., 2006.

Fonte: SETTRAN, 2005.

Quadro 15 - Número de acidentes por mês para todos os dias da semana, 2003

\begin{tabular}{|c|c|c|c|c|c|c|c|}
\hline Mês/Dia Semana & Domingo & Segunda & Terça & Quarta & Quinta & Sexta & Sábado \\
\hline Janeiro & 61 & 75 & 63 & 79 & 87 & 100 & 67 \\
\hline Fevereiro & 59 & 84 & 67 & 98 & 84 & 112 & 90 \\
\hline Março & 81 & 91 & 75 & 87 & 92 & 75 & 115 \\
\hline Abril & 72 & 74 & 99 & 119 & 85 & 79 & 86 \\
\hline Maio & 57 & 105 & 82 & 91 & 102 & 127 & 115 \\
\hline Junho & 82 & 113 & 89 & 92 & 91 & 96 & 104 \\
\hline Julho & 67 & 91 & 99 & 112 & 102 & 104 & 111 \\
\hline Agosto & 83 & 83 & 82 & 88 & 101 & 101 & 124 \\
\hline Setembro & 66 & 122 & 117 & 94 & 85 & 93 & 110 \\
\hline Outubro & 78 & 83 & 113 & 103 & 125 & 117 & 93 \\
\hline Novembro & 102 & 112 & 106 & 87 & 104 & 103 & 143 \\
\hline Dezembro & 73 & 135 & 113 & 127 & 81 & 109 & 101 \\
\hline
\end{tabular}

Legenda: 00=número maior de acidentes por dia da semana.

Org: BERNARDINO, A.R., 2006.

Fonte: SETTRAN, 2005.

Os números dos acidentes de trânsito por mês para o ano de 2004 (cf. gráfico 28 e quadro 16), relacionados com o dia da semana de maior número de eventos foram: aos sábados, as ocorrências para os meses de maio, junho, 
julho e outubro tiveram os maiores números registrados; na sexta-feira, os meses de janeiro, fevereiro e dezembro; na quinta-feira, os meses de abril e setembro; na terça-feira o mês de março sobressaiu aos demais; e, na segunda-feira, os meses de agosto e novembro tiveram números maiores de ocorrências de acidentes de transito.

Gráfico 28 - Número de acidentes por mês para todos os dias da semana, 2004

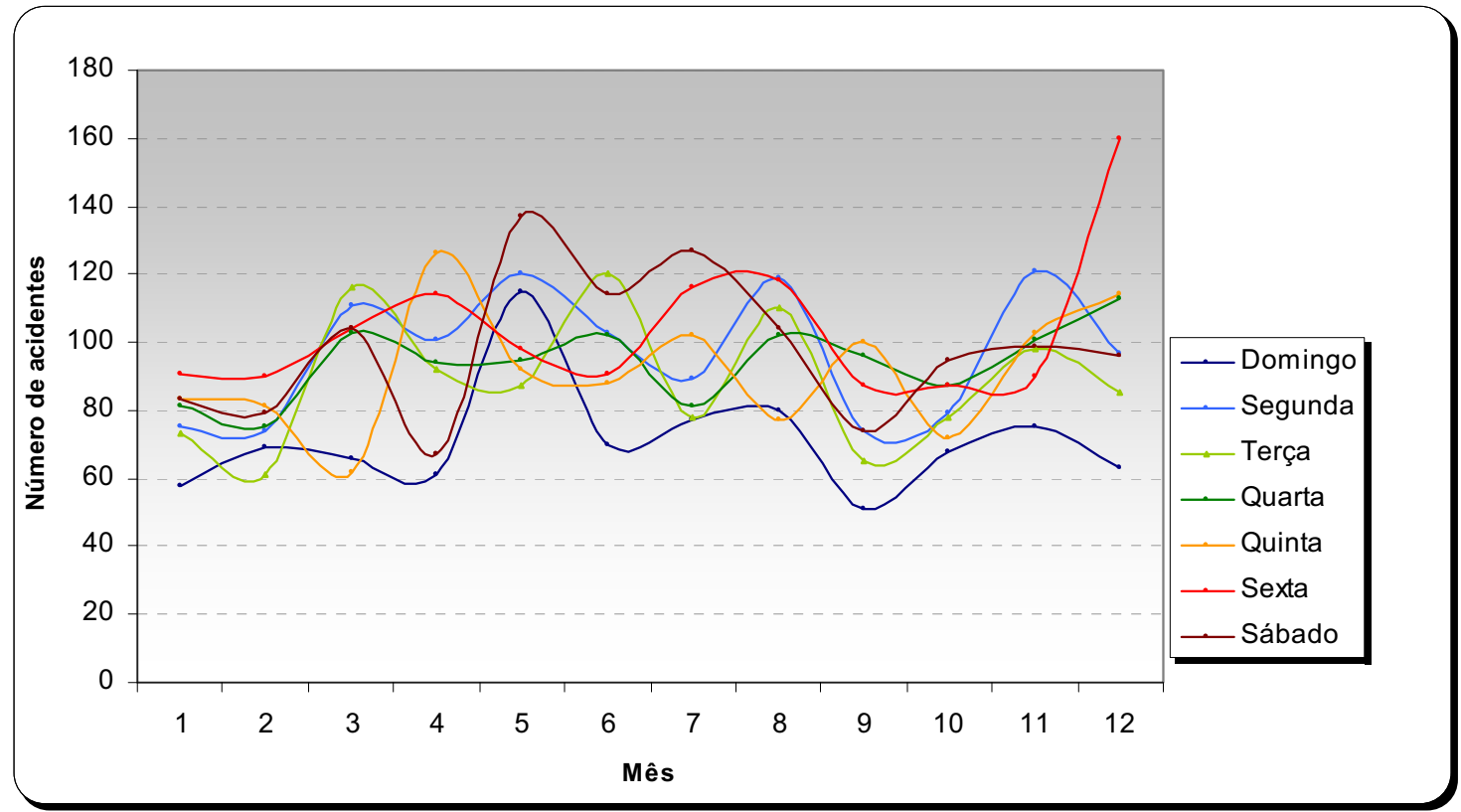

Org: BERNARDINO, A.R., 2006.

Fonte: SETTRAN, 2005.

Quadro 16 - Número de acidentes por mês para todos os dias da semana, 2004

\begin{tabular}{|c|c|c|c|c|c|c|c|}
\hline Mês/Dia Semana & Domingo & Segunda & Terça & Quarta & Quinta & Sexta & Sábado \\
\hline Janeiro & 58 & 75 & 73 & 81 & 83 & 91 & 83 \\
\hline Fevereiro & 69 & 74 & 61 & 75 & 81 & 90 & 79 \\
\hline Março & 66 & 111 & 116 & 103 & 62 & 104 & 104 \\
\hline Abril & 61 & 101 & 92 & 94 & 126 & 114 & 67 \\
\hline Maio & 115 & 120 & 87 & 95 & 92 & 98 & 137 \\
\hline Junho & 70 & 103 & 120 & 102 & 88 & 91 & 114 \\
\hline Julho & 77 & 89 & 78 & 81 & 102 & 116 & 127 \\
\hline Agosto & 80 & 119 & 110 & 102 & 77 & 118 & 104 \\
\hline Setembro & 51 & 74 & 65 & 96 & 100 & 87 & 74 \\
\hline Outubro & 68 & 79 & 78 & 87 & 72 & 87 & 95 \\
\hline Novembro & 75 & 121 & 98 & 101 & 103 & 90 & 99 \\
\hline Dezembro & 63 & 97 & 85 & 113 & 114 & 160 & 96 \\
\hline
\end{tabular}

Legenda: 00=número maior de acidentes por dia da semana.

Org: BERNARDINO, A.R., 2006.

Fonte: SETTRAN, 2005. 
A partir das variáveis relacionadas com a distribuição temporal, analisadas sobre os dias da semana em que ocorreram os acidentes de trânsito com maior número de registros, salienta-se que, em todos os anos, foi verificada a ocorrência de maior número de acidentes do dia da semana por mês para as sextas-feiras, sábados e segundas-feiras, sendo que o mesmo não ocorreu para os dias de domingo, terça e quarta e quinta-feira, os quais não apresentaram números maiores de ocorrências de acidentes de trânsito no dia da semana por mês para todos os anos (cf. quadros 12, 13, 14, 15 e 16).

Essas análises demonstraram que os finais de semana que envolvem os dias de sexta-feira e sábado, registram os maiores números referentes às ocorrências dos acidentes para todos os anos. Nesse sentido, reserva-se a justificativa de lazer, aliada ao consumo de bebidas alcoólicas e número diferenciado de pessoas no trânsito, buscando o entretenimento sem grandes compromissos e responsabilidades de pesos maiores entre outras conseqüências.

Em se tratando dos acidentes de trânsito por mês e comparando-os, em todos os anos trabalhados e os registros observados, apresentou-se, expressivamente, o mês de outubro para os anos de 2000 e 2002; na seqüência, o mês de fevereiro, para o ano de 2001; para o mês de novembro, o ano de 2003, e o mês de maio para o ano de 2004 (cf. gráfico 29 e quadro 17). 
Gráfico 29 - Número de acidentes por mês, 2000 a 2004.

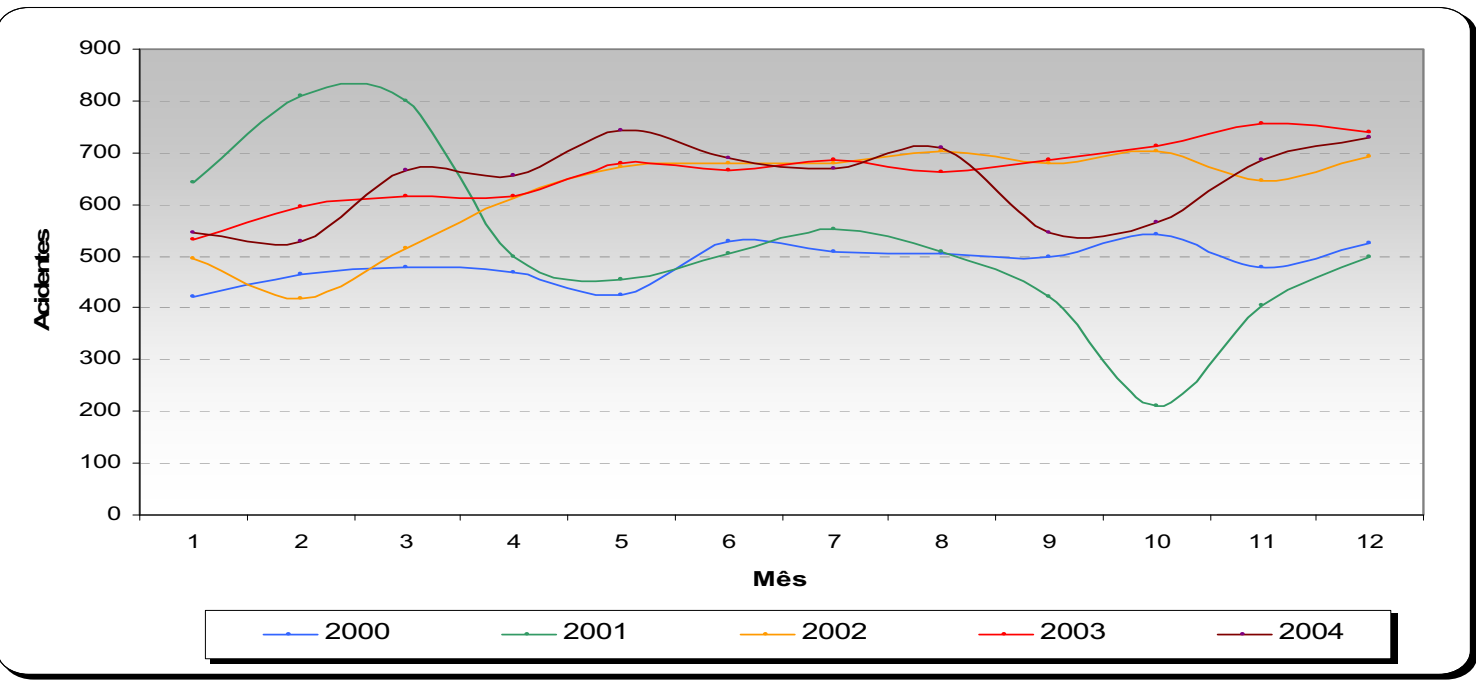

Org: BERNARDINO, A.R., 2006.

Fonte: SETTRAN, 2005.

Quadro 17 - Número de acidentes por mês, 2000 a 2004

\begin{tabular}{||c|c|c|c|c|c||}
\hline Mês/ano & $\mathbf{2 0 0 0}$ & $\mathbf{2 0 0 1}$ & $\mathbf{2 0 0 2}$ & $\mathbf{2 0 0 3}$ & $\mathbf{2 0 0 4}$ \\
\hline Janeiro & 423 & 644 & 496 & 532 & 544 \\
\hline Fevereiro & 466 & 808 & 417 & 594 & 529 \\
\hline Março & 477 & 798 & 515 & 616 & 666 \\
\hline Abril & 470 & 498 & 613 & 614 & 655 \\
\hline Maio & 425 & 456 & 672 & 679 & 744 \\
\hline Junho & 528 & 506 & 678 & 667 & 688 \\
\hline Julho & 510 & 552 & 679 & 686 & 670 \\
\hline Agosto & 506 & 510 & 701 & 662 & 710 \\
\hline Setembro & 499 & 420 & 679 & 687 & 547 \\
\hline Outubro & 542 & 212 & 701 & 712 & 566 \\
\hline Novembro & 480 & 406 & 645 & 757 & 687 \\
\hline Dezembro & 526 & 500 & 691 & 739 & 728 \\
\hline Total & $\mathbf{5 8 5 2}$ & $\mathbf{6 3 1 0}$ & $\mathbf{7 4 8 7}$ & $\mathbf{7 9 4 5}$ & $\mathbf{7 7 3 4}$ \\
\hline
\end{tabular}

Legenda: $000=$ número maior de registro de acidentes por mês

Org: BERNARDINO, A.R., 2006.

Fonte: SETTRAN, 2005.

O gráfico 30 e quadro 18 mostram que os registros dos acidentes de trânsito por ano se distribuem numa freqüência contínua nos quatro primeiros anos comparativos e decrescem irrelevantemente no ano de 2004. 
Gráfico 30 - Número de Acidentes por ano, 2000 a 2004

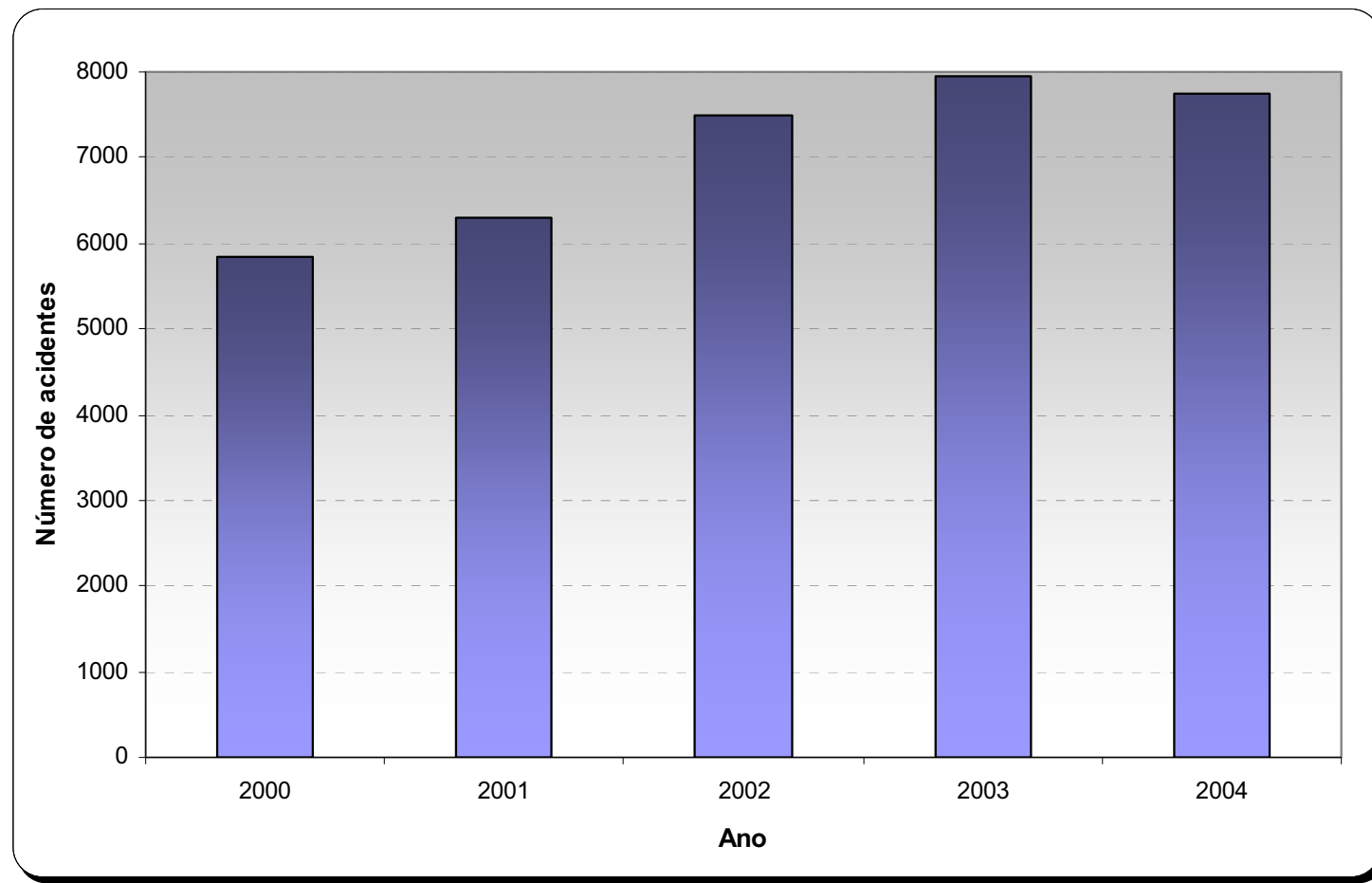

Org: BERNARDINO, A.R., 2006.

Fonte: SETTRAN, 2005.

Quadro 18 - Número de acidentes por ano, 2000 a 2004

\begin{tabular}{|c|c||}
\hline Ano & $\mathbf{N}^{\circ}$. Acidentes \\
\hline 2000 & 5852 \\
\hline 2001 & 6310 \\
\hline 2002 & 7487 \\
\hline 2003 & 7945 \\
\hline 2004 & 7734 \\
\hline
\end{tabular}

Org: BERNARDINO, A.R., 2006.

Fonte: SETTRAN, 2005.

Sintetizando os resultados das análises obtidas com base nos dados disponíveis sobre os acidentes de trânsito, identificou-se que aqueles referentes às características dos eventos para o tipo de veículos "carro" são os que mais envolvem nos conflitos, uma vez que se identificam em maior quantidade nas cidades.

Quanto à condição da via (seca, molhada, etc), os acidentes registrados na ocasião de pista seca superam todas as outras condições, o que se faz reconhecer que a pista molhada não pode ser condição importante nem ser 
analisada independente de outros parâmetros, além de que, os dias do ano de pista molhada, considerando as chuvas são reduzidos em relação aos dias de sol e pista seca.

As características das vias remetem-se à estrutura do sistema viário, em que os resultados significativos dos cruzamentos dos dados apresentaram, em sua maioria, conflitos de trânsito nos "cruzamentos" das vias e nas "retas", embora estes disponham de sinalizações semafóricas e/ou outras.

As causas que mais aparecem nos registros dos acidentes de trânsito são "pedestre ao longo da pista", "não usou os freios", "mudou subitamente de direção", "excesso de velocidade" e "desobedeceu ao sinal de pare", o que pode ser explicado, neste caso, pelo reflexo do condutor que não ocorreu no momento necessário, pois sua atenção estava desviada para outro motivo, quais sejam: poluição visual constante nas áreas centrais, uso do telefone celular, cansaço físico ou mental, denotando vínculo forte com o fator comportamental.

Nesses aspectos, surge outra discussão, pois nenhum desses supostos motivos pode ser encontrado nos formulários B.O. e somente poderiam ser reconhecidos, caso houvesse a possibilidade de uma entrevista, logo após o acidente com o condutor ou com o passageiro que estivesse acompanhando-o.

Quanto ao perfil do condutor, constatou-se que os acidentes de trânsito na sua maioria, ocorrem com os condutores que se encontram a menos de 10 anos de habilitação, denotando que a pequena experiência no trânsito pode ser considerada como fator relevante. Salienta-se que o aumento do número de registros dos acidentes de trânsito, apreciados na evolução dos anos 2000 a 2004, pode estar relacionado com o aumento do número da frota continuadamente expressiva e suas respectivas implicações, entre elas: as facilidades de financiamento na aquisição de veículos automotores, a depreciação da oferta do transporte público coletivo. 
A distribuição temporal dos dados mostrou que a maioria dos acidentes ocorre, em geral, durante as horas em que as repartições comerciais e os setores de serviços públicos estão em funcionamento, além do que "todos" veículos e pedestres - utilizam as vias para realizarem seus desejos cotidianos, sejam eles profissionais ou particulares, e se deslocar, na maioria, até as mesmas regiões da cidade.

Nessa variável, nota-se um expressivo número de ocorrências registradas nos dias de sextas-feiras e sábados, justificado pelos dias que regem o final de semana em que os cidadãos buscam o lazer e o entretenimento sem grandes responsabilidades sociais e/ou coletivas. 


\section{2 - Espacialização dos acidentes de trânsito considerando os números de maior ocorrência - 2000 a 2004, Uberlândia}

Para a espacialização dos dados dos acidentes de trânsito referentes aos anos de 2000 a 2004, selecionaram-se as vinte vias, os vinte trechos e os vinte principais cruzamentos de maior número de ocorrências de acidentes de trânsito da área urbana da cidade de Uberlândia.

A espacialização das vias ou segmentos viários é decorrente da sua importância, pois, em toda a sua extensão permite incluir, nas análises, sua área de abrangência, podendo ser considerada suas condições, assim como as ações de intervenções realizadas, como: os limites de velocidades, o volume do tráfego, obstáculos, sinalizações, retornos conflitantes, entre outras.

Os trechos apresentam-se como parte de um segmento viário que pode indicar locais específicos das vias que necessitam de tratamento, entre eles: implantar a fiscalização de velocidade máxima permitida, representada fisicamente pelo equipamento da lombada eletrônica, tendo em vista que trechos com periculosidade maior possuem a tendência de estar localizados em áreas de grande movimentação, em que decorrem as atividades de comércio e serviços instaladas no local e atraindo grupos de pessoas.

É essencial o conhecimento dos cruzamentos, pois são os mais representativos no que se refere à freqüência de acidentes, além de sua distribuição espacial específica na malha urbana oferecer possíveis detalhamentos pontuais e identificáveis. 
3.2.1 - Apresentação das vias com maior número de ocorrências de acidentes de trânsito para os anos de 2000 a 2004 e sua espacialização

Nos quadros 19, 20, 21, 22 e 23, apresentam-se as identificações das vias com seus logradouros e seus respectivos números de acidentes ocorridos nos anos de 2000 a 2004, hierarquizados em ordem decrescente.

Coloca-se, como ponto fundamental, a relevância para a via de maior número de acidentes, Av. João Naves de Ávila, que assume o mesmo destaque em todos os anos em análise, denotando uma grande importância no sistema viário de Uberlândia. Possui, aproximadamente, dez quilômetros de extensão, é caracterizada como uma das vias estruturais que absorve os maiores volumes de circulação de veículos, além de oferecer suporte viário ao eixo estrutural sul. É a via que compõe o corredor exclusivo do transporte urbano coletivo com tecnologia moderna, cujos locais de embarque e desembarque são realizados em estações fechadas e cobertas, locadas, assim, no canteiro central da via, que faz a integração dos bairros do setor sudeste até a área central da cidade.

O total de acidentes ocorridos, para os anos de 2002 e 2003, chegou a, aproximadamente, 500 registros na Av. João Naves de Ávila, que pode ser considerada relevante em se tratando de sua importância na rede viária da cidade. No ano de 2000, essa via aparece com 238 registros e, nos anos de 2001 e 2004 as vias observadas com maior número de acidentes foram Av. Getúlio Vargas e Av. Rondon Pacheco, que são também vias de trânsito rápido e que possuem fiscalizações do tipo lombada eletrônica para controlar a velocidade, como também de avanço de sinal.

A segunda via de maior ocorrência de acidentes é a Av. Rondon Pacheco, que aparece, repetidamente, nos outros anos, em posições de classificação de até o quinto lugar (cf. quadros 19, 20, 21, 22 e 23). É considerada uma via de trânsito rápida, com limite de velocidade de $70 \mathrm{~km} / \mathrm{h}$ em toda a sua extensão, com 
aproximadamente sete quilômetros, sendo a via mais importante que intercepta a Av. João Naves de Ávila. Possui fiscalização eletrônica, como os radares fixos em vários trechos, como pode ver visto no mapa 37.

As avenidas que compõem as vias com os maiores números de acidentes de trânsito apresentam-se como as que mais necessitam de intervenção, pois absorvem fluxos importantes do tráfego urbano.

As avenidas principais, em número de acidentes de trânsito e importância na hierarquia viária de Uberlândia, estão sinalizadas com semáforos e monitoradas em 132 interseções por meio do Controle de Tráfego em Área (CTA), que são sistemas de controle semafóricos compostos por laços detectores que se apresentam ligados a uma central de controle por meio de um computador. Isto possibilita a visualização do comportamento do tráfego e a intervenção mediante comandos acionados na central, diminuindo a necessidade de deslocamento até o local (VILELA, 2005).

Esse projeto possibilita a inserção de ondas verdes na área central e a alteração do ciclo semafórico em casos de transtornos, como; congestionamentos ou acidentes na área do entorno da interseção monitorada.

As avenidas Floriano Peixoto e Afonso Pena, vias da área central, que repetidamente surgem nos dados analisados, também são consideradas as vias que registram números relevantes de acidentes de trânsito, as quais foram contempladas em grande extensão por esse projeto do CTA. São vias com alto fluxo de veículos e agrupamento de pessoas, pois compõem-se de atividades mistas, desde serviços comerciais até clínicas médico-odontológicas.

Os mapas 6, 7, 8, 9 e 10, na seqüência, apresentam a espacialização das vinte vias para os anos analisados, cujos números indicados correspondem aos logradouros e respectivos números de acidentes apontados nos quadros 19, 20, 21,22 e 23. 
a) as vinte vias com maior número de acidentes, 2000

Quadro 19 - As vinte vias com maior número de ocorrências de acidentes de trânsito, ano 2000, Uberlândia

\begin{tabular}{|c|l|c|}
\hline & Via Principal & $\begin{array}{c}\mathbf{N}^{\mathbf{o}} . \\
\text { Acidentes }\end{array}$ \\
\hline 1 & Av. João Naves de Ávila & 238 \\
\hline 2 & Av. Rondon Pacheco & 196 \\
\hline 3 & Av. Afonso Pena & 161 \\
\hline 4 & Av. Floriano Peixoto & 146 \\
\hline 5 & Av. Getúlio Vargas & 98 \\
\hline 6 & Av. Cesário Alvim & 94 \\
\hline 7 & Av. João Pinheiro & 79 \\
\hline 8 & R. Duque de Caxias & 77 \\
\hline 9 & Av. Brasil & 52 \\
\hline 10 & Av. Nicomedes Alves dos Santos & 51 \\
\hline 11 & Av. Belarmino Cotta Pacheco & 46 \\
\hline 12 & Av. Segismundo Pereira & 46 \\
\hline 13 & Av. Antonio Thomaz Ferreira de Rezende & 43 \\
\hline 14 & Av. Monsenhor Eduardo & 39 \\
\hline 15 & R. Tupaciguara & 38 \\
\hline 16 & R. Olegário Maciel & 37 \\
\hline 17 & Av. Anselmo Alves Dos Santos & 34 \\
\hline 18 & R. Cel Antonio Alves Pereira & 32 \\
\hline 19 & R. Indianópolis & 32 \\
\hline 20 & Av. Raulino Cotta Pacheco & 32 \\
\hline $0 r g:$ & BERARDINO, A.R., 2006. & \\
\hline 1
\end{tabular}

Org: BERNARDINO, A.R., 2006.

Fonte: SETTRAN, 2000. 
b) as vinte vias com maior número de acidentes, 2001

Quadro 20 - As vinte vias com maior número de ocorrências de acidentes de trânsito, ano 2001, Uberlândia

\begin{tabular}{|c|c|c|}
\hline Ord. & Via Principal & $\begin{array}{c}\mathbf{N}^{\circ} . \\
\text { Acidentes }\end{array}$ \\
\hline 1 & Av. Getúlio Vargas & 119 \\
\hline 2 & Av. Antonio Thomaz Ferreira de Rezende & 70 \\
\hline 3 & Av. Engenheiro Diniz & 62 \\
\hline 4 & Av. Fernando Vilela & 58 \\
\hline 5 & Av. Rondon Pacheco & 53 \\
\hline 6 & Av. Vasconcelos Costa & 53 \\
\hline 7 & Av. João Pinheiro & 48 \\
\hline 8 & Av. Araguari & 43 \\
\hline 9 & Av. Aspirante Mega & 39 \\
\hline 10 & Av. Nicomedes Alves dos Santos & 38 \\
\hline 11 & Av. Floriano Peixoto & 37 \\
\hline 12 & Av. Cesário Crosara & 36 \\
\hline 13 & Av. José Andraus Gassani & 36 \\
\hline 14 & Av. Monsenhor Eduardo & 36 \\
\hline 15 & Av. João Naves de Avila & 35 \\
\hline 16 & Av. José Fonseca E Silva & 32 \\
\hline 17 & Av. Raulino Cotta Pacheco & 32 \\
\hline 18 & Av. Afonso Pena & 28 \\
\hline 19 & Av. Marcos de Freitas Costa & 28 \\
\hline 20 & Av. Comendador Alexandrino Garcia & 26 \\
\hline
\end{tabular}

Org: BERNARDINO, A.R., 2006.

Fonte: SETTRAN, 2001. 
c) as vinte vias com maior número de acidentes, 2002

Quadro 21 - As vinte vias com maior número de ocorrências de acidentes de trânsito, ano 2002, Uberlândia

\begin{tabular}{|c|l|c|}
\hline & Via Principal & $\begin{array}{c}\mathbf{N}^{\mathbf{0}} . \\
\text { Acidentes }\end{array}$ \\
\hline 1 & Av João Naves de Ávila & 477 \\
\hline 2 & Av Floriano Peixoto & 336 \\
\hline 3 & Av Rondon Pacheco & 301 \\
\hline 4 & Av Afonso Pena & 289 \\
\hline 5 & Av João Pinheiro & 240 \\
\hline 6 & Av. Cesário Alvim & 177 \\
\hline 7 & Av. Getúlio Vargas & 171 \\
\hline 8 & Av. Brasil & 107 \\
\hline 9 & Av. Nicomedes Alves dos Santos & 102 \\
\hline 10 & Av. Fernando Vilela & 98 \\
\hline 11 & Av. Antonio Thomaz Ferreira de Rezende & 93 \\
\hline 12 & Av. Segismundo Pereira & 92 \\
\hline 13 & Av. Engenheiro Diniz & 84 \\
\hline 14 & Av. Araguari & 80 \\
\hline 15 & Av. José Fonseca e Silva & 75 \\
\hline 16 & Av. Belarmino Cotta Pacheco & 73 \\
\hline 17 & Av. Monsenhor Eduardo & 71 \\
\hline 18 & Av. Aspirante Mega & 65 \\
\hline 19 & Av. Cesário Crosara & 64 \\
\hline 20 & Av. José Andraus Gassani & 64 \\
\hline
\end{tabular}

Org: BERNARDINO, A.R., 2006.

Fonte: SETTRAN, 2002. 
d) as vinte vias com maior número de acidentes, 2003

Quadro 22 - As vinte vias com maior número de ocorrências de acidentes de trânsito, ano 2003, Uberlândia

\begin{tabular}{|c|l|c|}
\hline & Via Principal & $\begin{array}{c}\mathbf{N}^{\mathbf{0}} \\
\text { Acidentes }\end{array}$ \\
\hline 1 & Av João Naves de Ávila & 494 \\
\hline 2 & Av Rondon Pacheco & 382 \\
\hline 3 & Av Floriano Peixoto & 372 \\
\hline 4 & Av Afonso Pena & 284 \\
\hline 5 & Av João Pinheiro & 271 \\
\hline 6 & Av Getúlio Vargas & 157 \\
\hline 7 & Av Cesário Alvim & 145 \\
\hline 8 & Av Brasil & 125 \\
\hline 9 & Av Segismundo Pereira & 115 \\
\hline 10 & Av Anselmo Alves dos Santos & 104 \\
\hline 11 & Av Monsenhor Eduardo & 99 \\
\hline 12 & Av Fernando Vilela & 94 \\
\hline 13 & Av Aspirante Mega & 93 \\
\hline 14 & Av Belarmino Cotta Pacheco & 89 \\
\hline 15 & Av José Fonseca e Silva & 85 \\
\hline 16 & Av Vasconcelos Costa & 84 \\
\hline 17 & Av Nicomedes Alves dos Santos & 76 \\
\hline 18 & Av Antônio Thomaz Ferreira de Rezende & 74 \\
\hline 19 & Av José Andraus Gassani & 74 \\
\hline 20 & Av João Pessoa & 72 \\
\hline
\end{tabular}

Org: BERNARDINO, A.R., 2006.

Fonte: SETTRAN, 2003. 
e) as vinte vias com maior número de acidentes, 2004

Quadro 23 - As vinte vias com maior número de ocorrências de acidentes de trânsito, ano 2004, Uberlândia

\begin{tabular}{|c|l|c||}
\hline & Via Principal & $\begin{array}{c}\mathbf{N}^{\mathbf{o}} \\
\text { Acidentes }\end{array}$ \\
\hline 1 & Av. Rondon Pacheco & 142 \\
\hline 2 & Av. João Naves de Ávila & 58 \\
\hline 3 & BR-365/BR-050/BR-452 & 40 \\
\hline 4 & Av. Getúlio Vargas & 30 \\
\hline 5 & Av. Anselmo Alves dos Santos & 26 \\
\hline 6 & Av. Nicomedes Alves dos Santos & 24 \\
\hline 7 & Av. José Andraus Gassani & 20 \\
\hline 8 & Av. Profa. Minervina Cândida de Oliveira & 16 \\
\hline 9 & R. Will Cargill & 15 \\
\hline 10 & Av. José Fonseca e Silva & 14 \\
\hline 11 & Av. Antônio Thomaz F. Rezende & 10 \\
\hline 12 & Av. Neusa Resende & 10 \\
\hline 13 & Av. Segismundo Pereira & 10 \\
\hline 14 & Av. Francisco Galassi & 9 \\
\hline 15 & Av. Pará & 8 \\
\hline 16 & Av. Aldo Borges Leão & 7 \\
\hline 17 & Av. Francisco Bernardes Assis & 7 \\
\hline 18 & Av. Paulo Roberto C. Santos & 7 \\
\hline 19 & Av. Floriano Peixoto & 7 \\
\hline 20 & Anel Viário Ayrton Senna & 6 \\
\hline & BERNARDINO, A.R., 2006. & \\
\hline
\end{tabular}

Org: BERNARDINO, A.R., 2006.

Fonte: SETTRAN, 2004. 
3.2.2 - Apresentação dos trechos com maior número de ocorrências de acidentes de trânsito para os anos de 2000 a 2004 e sua espacialização

Nos quadros 24, 25, 26, 27 e 28, apresenta-se a identificação dos trechos com seus logradouros e seus respectivos números de acidentes ocorridos nos anos de 2000 a 2004, hierarquizados em ordem decrescente.

Amplamente, verifica-se uma distribuição espacial dos acidentes mais intensificada na área central da cidade. Observa-se que são acidentes ocorridos nas avenidas que, em geral, contêm a sinalização de trânsito necessária, ou em trechos como da Av. João Pinheiro entre Av. João Pinheiro e Av. Afonso Pena, local em que está localizado o Terminal Central e onde há a movimentação de pedestres e ônibus mais intensa.

Observa-se, que também no trecho da Av. João Pinheiro entre R. Bernardo Guimarães e Pça. Adolfo Fonseca, há um hipermercado, e o fluxo de veículos, ônibus e pedestres é forte. Outros trechos apresentam-se com um fluxo intenso de pedestres devido à proximidade com os pontos de ônibus, as escolas, os bancos, as lojas populares, etc, onde os veículos também se agrupam em horários de pico, principalmente. Exemplificando que os trechos que abrangem a Pça. Tubal Vilela, compreendendo as Av. Floriano Peixoto e Av. Afonso Pena e Ruas Olegário Maciel e Duque de Caxias na área central, também possuem tais condições.

O trecho da Av. João Naves de Ávila, compreendido entre a R. Luiza de Jesus e Av. Ubiratan Honório de Castro, apresenta intensidade de veículos nos dois sentidos. Acrescenta-se a disposição do shopping center e de um hipermercado, cujas entradas principais de pedestres e veículos estão direcionadas a esse trecho. 
Referente à Av. Rondon Pacheco, cujos equipamentos de fiscalização eletrônica foram implantados no ano de 2001, tem-se a avaliar que, após o ano de 2000 , dentre os anos analisados, deixou de ser enumerada para os trechos em que mais ocorrem números de acidentes de trânsito, denotando que tais equipamentos oferecem mais segurança aos deslocamentos.

Nos mapas 11, 12, 13, 14 e 15, demonstra-se a espacialização dos trechos de maior número de ocorrências de acidentes de trânsito para cada ano trabalhado, sendo os números indicados neles correspondentes aos que compõem os quadros $24,25,26,27$ e 28.

a) os vinte trechos com maior número de acidentes, 2000

Quadro 24 - Os vinte trechos com maior número de ocorrências de acidentes de trânsito, ano 2000, Uberlândia

\begin{tabular}{|c|l|l|l|c|}
\hline \hline & Via Principal & Interseção 1 & Interseção 2 & $\begin{array}{c}\mathbf{N}^{\circ} . \\
\text { Acidentes }\end{array}$ \\
\hline 1 & João Naves de Ávila & Luiza de Jesus & Ubiratan Honório de Castro & 34 \\
\hline 2 & Rondon Pacheco & Maria Vilela Ribeiro & José de Moraes & 11 \\
\hline 3 & Rondon Pacheco & Prof. Mário Porto & Rio Preto & 10 \\
\hline 4 & Rondon Pacheco & Olegário Maciel & Duque de Caxias & 8 \\
\hline 5 & Rondon Pacheco & Quintino Bocaiúva & Cel. Antônio Alves Pereira & 8 \\
\hline 6 & Floriano Peixoto & Santos Dumont & Olegário Maciel & 8 \\
\hline 7 & João Naves de Ávila & Cesário Alvim & Agenor Paes & 6 \\
\hline 8 & João Naves de Ávila & Floriano Peixoto & Cesário Alvim & 6 \\
\hline 9 & João Pinheiro & Machado de Assis & Tenente Virmondes & 6 \\
\hline 10 & Machado de Assis & Afonso Pena & Floriano Peixoto & 5 \\
\hline 11 & João Naves de Ávila & Belarmino Cotta Pacheco & Manoel dos Santos & 5 \\
\hline 12 & Antonio Thomaz F. Rezende & Farroupilhas & Sabinadas & 5 \\
\hline 13 & Getúlio Vargas & General Canabarro & Itajubá & 5 \\
\hline 14 & João Naves de Ávila & João Mendes & Conselheiro Lafaiete & 5 \\
\hline 15 & Rondon Pacheco & Rezende & Joaquim Cordeiro & 5 \\
\hline 16 & José Andraus Gassani & Afonso Egydio de Souza & Wandelvart Faria Marquez & 4 \\
\hline 17 & Vitalino R. do Carmo & Alexandre R. Guimarães & João XXIII & 4 \\
\hline 18 & Floriano Peixoto & Duque de Caxias & Machado de Assis & 4 \\
\hline 19 & Duque de Caxias & Floriano Peixoto & Cesário Alvim & 4 \\
\hline 20 & Olegário Maciel & João Pinheiro & Afonso Pena & 4 \\
\hline
\end{tabular}

Org: BERNARDINO, A.R., 2006.

Fonte: SETTRAN, 2000. 
b) os vinte trechos com maior número de acidentes, 2001

Quadro 25 - Os vinte trechos com maior número de ocorrências de acidentes de trânsito, ano 2001, Uberlândia

\begin{tabular}{||l|l|l|l|c|}
\hline & Via Principal & Interseção 1 & Interseção 2 & $\begin{array}{c}\mathbf{N}^{\circ} . \\
\text { Acidentes }\end{array}$ \\
\hline 1 & Av. João Pinheiro & R. Bernardo Guimarães & Pça. Adolfo Fonseca & 5 \\
\hline 2 & Av. Cesário Crosara & R. Ordália C. Oliveira & R. Douglas Andreani & 4 \\
\hline 3 & Av. Getúlio Vargas & R. General Canabarro & R. Itajubá & 4 \\
\hline 4 & Av. Getúio Vargas & R. Duque de Caxias & R. Olegário Maciel & 4 \\
\hline 5 & Av. Afrânio R. da Cunha & R. Tiradentes & R. Quinze de Novembro & 3 \\
\hline 6 & Av. Cel. José T. Carneiro & R. Beira Rio & Av. Uberabinha & 3 \\
\hline 7 & Av. Fernando Vilela & R. Vieira Gonçalves & R. Carmo Gifoni & 3 \\
\hline 8 & Av. Indaiá & R. do Bancário & R. do Estudante & 3 \\
\hline 9 & Av. Raulino C. Pacheco & Av. Fernando Vilela & R. Prof. João Basilio & 3 \\
\hline 10 & R. Engenheiro Azeli & R. Monte Carmelo & R. Indianóolis & 3 \\
\hline 11 & Av. Afonso Pena & R. Santos Dumont & R. Olegário Maciel & 2 \\
\hline 12 & Av. Afrânio R. da Cunha & R. Quinze de Novembro & R. Cel. Severiano & 2 \\
\hline 13 & Av. Araguari & R. Carmo Gifoni & R. Vieira Gonçalves & 2 \\
\hline 14 & Av. Cesário Crosara & R. Carlos Vilela Marquez & R. Orlando De Sousa & 2 \\
\hline 15 & Av. Com.Alexandrino Garcia & R. Claudemiro J.de Souza & R. Bahia & 2 \\
\hline 16 & Av. Constelação & R. Antônio Carrijo & R. Plutão & 2 \\
\hline 17 & Av. Constelação & R. Cometa & R. Luanda & 2 \\
\hline 18 & Av. Estrela do Sul & R. Ibiá & R. Divinópolis & 2 \\
\hline 19 & Av. Francisco Galassi & Av. das Américas & R. Cruzeiro & 2 \\
\hline 20 & Av. Getúlio Vargas & R. Álvares Cabral & Av. Aspirante Mega & 2 \\
\hline
\end{tabular}

Org: BERNARDINO, A.R., 2006.

Fonte: SETTRAN, 2001. 
c) os vinte trechos com maior número de acidentes, 2002

Quadro 26 - Os vinte trechos com maior número de ocorrências de acidentes de trânsito, ano 2002, Uberlândia

\begin{tabular}{||c|l|l|l|c||}
\hline \hline & Via Principal & Interseção 1 & Interseção 2 & $\begin{array}{c}\mathbf{N}^{\circ} \\
\text { Acidentes }\end{array}$ \\
\hline 1 & Av Afonso Pena & R Duque de Caxias & R Machado de Assis & 11 \\
\hline 2 & Av João Naves de Ávila & R Cassimiro de Abreu & R São Francisco de Assis & 9 \\
\hline 3 & Av Afonso Pena & R Tenente Virmondes & R Quintino Bocaiúva & 7 \\
\hline 4 & Av Getúlio Vargas & R General Canabarro & R Itajubá & 7 \\
\hline 5 & Pça. Tubal Vilela & R Olegário Maciel & R Duque de Caxias & 7 \\
\hline 6 & Av Afonso Pena & R Goiás & R Santos Dumont & 6 \\
\hline 7 & Av Antônio Thomaz F. Rez. & Av Visconde de Mauá & Av Farroupilhas & 6 \\
\hline 8 & Av João Naves de Ávila & Av Cesário Alvim & R Agenor Paes & 6 \\
\hline 9 & Av Afonso Pena & R Cruzeiro dos Peixotos & R Roosevelt de Oliveira & 5 \\
\hline 10 & Av Floriano Peixoto & R Itumbiara & R Buriti Alegre & 5 \\
\hline 11 & Av Floriano Peixoto & R Tenente Virmondes & R Quintino Bocaiúva & 5 \\
\hline 12 & Av Getúlio Vargas & R Tenente Virmondes & R Machado de Assis & 5 \\
\hline 13 & Av João Naves de Ávila & Av Belarmino C. Pacheco & Av Manoel dos Santos & 5 \\
\hline 14 & Av João Naves de Ávila & Av Floriano Peixoto & Av Cesário Alvim & 5 \\
\hline 15 & Av João Pinheiro & R Cel. Antonio A. Pereira & Pça Sérgio Pacheco & 5 \\
\hline 16 & Av João Pinheiro & R Bernardo Guimarães & Pça Adolfo Fonseca & 5 \\
\hline 17 & Av João Pinheiro & R Santos Dumont & R Olegário Maciel & 5 \\
\hline 18 & Av José A. Gassani & R Wandelvart F. Marquez & R Afonso Egydio Souza & 5 \\
\hline 19 & Av Raulino C. Pacheco & R Conquista & Av Prof. Minervina Oliveira & 5 \\
\hline 20 & R Bernardo Guimarães & Pça. Rui Barbosa & Av Afonso Pena & 5 \\
\hline
\end{tabular}

Org: BERNARDINO, A.R., 2006.

Fonte: SETTRAN, 2002. 
d) os vinte trechos com maior número de acidentes, 2003

Quadro 27 - Os vinte trechos com maior número de ocorrências de acidentes de trânsito, ano 2003, Uberlândia

\begin{tabular}{||c|l|l|l|c|}
\hline \hline & Via Principal & Interseção 1 & Interseção 2 & $\begin{array}{c}\mathbf{N}^{\circ} \\
\text { Acidentes }\end{array}$ \\
\hline 1 & Av João Pessoa & Av Afonso Pena & Av João Pinheiro & 16 \\
\hline 2 & Av Antônio Thomaz F.Rezende & Av Visconde de Mauá & Av Farroupilhas & 14 \\
\hline 3 & Av Afonso Pena & R Tenente Virmondes & R Quintino Bocaiúva & 11 \\
\hline 4 & Av Anselmo A. dos Santos & R Licydio Paes & R Armando Tucci & 11 \\
\hline 5 & Av João Naves de Ávila & Av Manoel dos Santos & Av Vitalino R. do Carmo & 11 \\
\hline 6 & Av João Pinheiro & R Machado de Assis & R Tenente Virmondes & 11 \\
\hline 7 & Av Cleanto V.Gonçalves & R Rubens Cazabona & R Treze de Maio & 10 \\
\hline 8 & Av João Naves de Ávila & Av Rondon Pacheco & Av Anselmo AlvesSantos & 10 \\
\hline 9 & Av Afonso Pena & R Machado de Assis & R Tenente Virmondes & 9 \\
\hline 10 & Av Floriano Peixoto & R Quintino Bocaiúva & R Cel Antônio A. Pereira & 9 \\
\hline 11 & Av Getulio Vargas & R General Canabarro & R Itajubá & 9 \\
\hline 12 & Av João Naves de Ávila & Av Floriano Peixoto & Av Cesário Alvim & 9 \\
\hline 13 & Av Uirapuru & R José Oliveira Pinto & R dos Pardais & 9 \\
\hline 14 & Av Afonso Pena & R Santos Dumont & R Olegário Maciel & 8 \\
\hline 15 & Av Benjamin Magalhães & R Nicarágua & R Venezuela & 8 \\
\hline 16 & Av Floriano Peixoto & R Duque de Caxias & R Machado de Assis & 8 \\
\hline 17 & Av João Naves de Ávila & Av José Rezende Costa & Av Jerônimo Maia Santos & 8 \\
\hline 18 & Av João Naves de Ávila & Av Cesário Alvim & R Agenor Paes & 8 \\
\hline 19 & R Tenente Virmondes & Av Afonso Pena & Av Floriano Peixoto & 8 \\
\hline 20 & Av Cel José T. Carneiro & R Luiz Ferreira Lima & R Beira Rio & 7 \\
\hline
\end{tabular}

Org: BERNARDINO, A.R., 2006.

Fonte: SETTRAN, 2003. 
e) os vinte trechos com maior número de acidentes, 2004

Quadro 28 - Os vinte trechos com maior número de ocorrências de acidentes de trânsito, ano 2004, Uberlândia

\begin{tabular}{|c|l|l|l|c||}
\hline & Via Principal & Interseção 1 & Interseção 2 & $\begin{array}{c}\text { N}^{\circ} \\
\text { Acidentes }\end{array}$ \\
\hline 1 & Av. Afonso Pena & R. Quintino Bocaiúva & R. Tenente Virmondes & 16 \\
\hline 2 & Av. João Naves de Ávila & Av. Cesário Alvim & Av. Floriano Peixoto & 15 \\
\hline 3 & Av. Afonso Pena & R. Abdalla Haddad & R. Martinésia & 10 \\
\hline 4 & R. Goiás & Av. Afonso Pena & Av. João Pinheiro & 10 \\
\hline 5 & Av. João Pinheiro & R. Olegário Maciel & R. Santos Dumont & 9 \\
\hline 6 & Av. Floriano Peixoto & R. Machado de Assis & R. Tenente Virmondes & 9 \\
\hline 7 & Av. Antonio ThomazF. Rez. & Av. Cabanadas & R. Garcia Lorca & 8 \\
\hline 8 & Av. Antonio ThomazF. Rez. & Av. Farroupilhas & Av. Visconde de Mauá & 8 \\
\hline 9 & R. Duque de Caxias & Av. Afonso Pena & Av. João Pinheiro & 8 \\
\hline 10 & Av. Afonso Pena & R. Goiás & R. Santos Dumont & 8 \\
\hline 11 & Av. João Pessoa & Av. Afonso Pena & Av. João Pinheiro & 7 \\
\hline 12 & Av. Getúlio Vargas & R. General Canabarro & R. Itajubá & 7 \\
\hline 13 & R. Cel José T. Carneiro & R. Beira Rio & R. Luiz Ferreira Lima & 7 \\
\hline 14 & Av. João Naves de Ávila & R. Agenor Paes & Av. Cesário Alvim & 7 \\
\hline 15 & Av. Floriano Peixoto & R. Goiás & R. Santos Dumont & 7 \\
\hline 16 & R. Machado de Assis & Av. Afonso Pena & Av. Floriano Peixoto & 7 \\
\hline 17 & Av. José A. Gassani & R. Afonso Egydio Souza & R. Wandelvart F. Marquez & 7 \\
\hline 18 & Av. Floriano Peixoto & R. Olegário Maciel & R. Santos Dumont & 6 \\
\hline 19 & Av. Getúlio Vargas & R. José Bonifácio & R. Vital Macedo & 6 \\
\hline 20 & Tubal Vilela & R. Duque de Caxias & R. Olegário Maciel & 6 \\
\hline
\end{tabular}

Org: BERNARDINO, A.R., 2006.

Fonte: SETTRAN, 2004. 
3.2.3 - Apresentação dos cruzamentos com maior número de ocorrências de acidentes de trânsito para os anos de 2000 a 2004 e sua espacialização

Os cruzamentos identificados que apresentam o maior número de acidentes por ano e são reapresentados em todos os outros anos (com exceção do ano de 2001, justificado no capítulo 2) estão contemplados nas vias de maior número de acidentes e nos trechos, a saber, a Av. João Naves de Ávila, Av. Floriano Peixoto, Av. Afonso Pena e Av. Antônio Thomaz Ferreira de Rezende, principalmente. Estas, quando interceptadas por outra via, instituem o cruzamento, que, assim, forma um local apto à ocorrência de acidentes de trânsito, tendo em vista a probabilidade de conflitos entre veículos pelos altos volumes veiculares por hora. Verifica-se que a distribuição espacial dos acidentes com maior número de eventos encontra-se na área central e seu entorno (cf. quadros $29,30,31,32$ e 33 ).

Confirma-se que os cruzamentos de maior número de acidentes locados fora da área central ocorrem em vias de trânsito rápido, que oferecem boas condições para exceder a velocidade máxima permitida, além do que possuem outras vias que as interceptam, implicando a insegurança de sua travessia ou mesmo a desobediência à sinalização viária pelo condutor, o que possibilita a ocorrência do acidente. As Av. Antônio Thomaz Ferreira de Rezende, Av. Belarmino Cotta Pacheco, Av. Indaiá e as próprias vias importantes Av. João Naves de Ávila e Av. Rondon Pacheco, que se estendem além da área central, identificam-se a essas características.

A espacialização dos vinte cruzamentos de maior número de acidentes de trânsito pode ser observada nos mapas $16,17,18,19$ e 20, nos quais os números lá indicados correspondem aos dos quadros 29, 30, 31, 32 e 33, respectivamente.

É relevante o fluxo de veículos que utilizam o cruzamento da Av. João Naves de Ávila com Av. Rondon Pacheco. Por meio do equipamento que compõe a Central da CTA da SETTRAN, é possível saber que, nesse cruzamento, a 
média por horários encontra-se entre 1.300 e 1.600 veículos/hora e em aproximados 60.000 veículos/dia.

a) os vinte cruzamentos com maior número de acidentes, 2000

Quadro 29 - Os vinte cruzamentos com maior número de ocorrências de acidentes de trânsito, ano 2000, Uberlândia

\begin{tabular}{||c|l|l|c||}
\hline \hline & Via Principal & Interseção & $\begin{array}{c}\mathbf{N}^{\circ} \\
\text { Acidentes }\end{array}$ \\
\hline 1 & João Naves de Ávila & Rondon Pacheco & 83 \\
\hline 2 & Nicomedes Alves dos Santos & Rondon Pacheco & 35 \\
\hline 4 & Cesário Alvim & João Naves de Ávila & 20 \\
\hline 5 & João Naves de Ávila & João Pinheiro & 17 \\
\hline 6 & Antonio Thomaz Ferreira de Rezende & Segismundo Pereira & 17 \\
\hline 7 & Duque de Caxias & Comendador Alexandrino Garcia & 16 \\
\hline 8 & Getúlio Vargas & Pao Francisco de Assis & 15 \\
\hline 9 & Afonso Pena & João Pessoa & 15 \\
\hline 10 & Belarmino Cotta Pacheco & Sebastião Rangel & 13 \\
\hline 11 & Cipriano Del'Fávero & João Pessoa & 13 \\
\hline 12 & Fernando Vilela & Vieira Gonçalves & 13 \\
\hline 13 & Mário Rezende Ribeiro & Rio Branco & 13 \\
\hline 14 & Rondon Pacheco & Vitalino Rezende do Carmo & 13 \\
\hline 15 & Afonso Pena & Goiás & 13 \\
\hline 16 & Dos Municípios & Rondon Pacheco & 12 \\
\hline 17 & Floriano Peixoto & Porto Alegre & 12 \\
\hline 18 & Cel. Antônio Alves Pereira & Floriano Peixoto & 12 \\
\hline 19 & Floriano Peixoto & Santos Dumont & 11 \\
\hline 20 & Floriano Peixoto & Machado de Assis & 11 \\
\hline \hline
\end{tabular}

Org: BERNARDINO, A.R., 2006.

Fonte: SETTRAN, 2000. 
b) os vinte cruzamentos com maior número de acidentes, 2001

Quadro 30 - Os vinte cruzamentos com maior número de ocorrências de acidentes de trânsito, ano 2001, Uberlândia

\begin{tabular}{||c|l|l|c|}
\hline & Via Principal & Interseção & $\begin{array}{c}\mathbf{N}^{\circ} . \\
\text { Acidentes }\end{array}$ \\
\hline 1 & Av. Antonio Thomaz Ferreira de Rezende & Av. Comendador A. Garcia & 26 \\
\hline 2 & Av. Engenheiro Diniz & R. Engenheiro Azeli & 18 \\
\hline 3 & Av. Brigadeiro Sampaio & Av. Ipê & 9 \\
\hline 4 & Av. Engenheiro Diniz & Av. Raulino Cotta Pacheco & 9 \\
\hline 5 & Av. Fernando Vilela & Av. Marcos de Freitas Costa & 9 \\
\hline 6 & Av. Profa. Minervina Cândida Oliveira & Av. Raulino Cotta Pacheco & 9 \\
\hline 7 & Av. Fernando Vilela & Av. João Pessoa & 8 \\
\hline 8 & Av. João Naves de Ávila & Av. Rondon Pacheco & 8 \\
\hline 9 & Av. Paes Leme & R. Tapuirama & 8 \\
\hline 10 & Av. dos Municípios & Av. Rondon Pacheco & 7 \\
\hline 11 & Av. Getúlio Vargas & Av. Marcos de Freitas Costa & 7 \\
\hline 12 & Av. Indaiá & R. da Secretaria & 7 \\
\hline 13 & Av. Raulino Cotta Pacheco & Av. Vasconcelos Costa & 7 \\
\hline 14 & Av. Araguari & R. Rodrigues da Cunha & 6 \\
\hline 15 & Av. Aspirante Mega & Av. Getúlio Vargas & 6 \\
\hline 16 & Av. Aspirante Mega & Av. Imbaúba & 6 \\
\hline 17 & Av. Engenheiro Diniz & R. Vieira Gonçalves & 6 \\
\hline 18 & Av. Engenheiro Diniz & R. México & 6 \\
\hline 19 & Av. Getúlio Vargas & R. Olegário Maciel & 6 \\
\hline 20 & Av. Getúlio Vargas & Av. Raulino Cotta Pacheco & 6 \\
\hline
\end{tabular}

Org: BERNARDINO, A.R., 2006.

Fonte: SETTRAN, 2001. 
c) os vinte cruzamentos com maior número de acidentes, 2002

Quadro 31 - Os vinte cruzamentos com maior número de ocorrências de acidentes de trânsito, ano 2002, Uberlândia

\begin{tabular}{||c|l|l|c||}
\hline \hline & Interseção & $\begin{array}{c}\mathbf{N}^{\mathbf{o}} \\
\text { Acidentes }\end{array}$ \\
\hline 1 & Av João Naves de Ávila & Av Rondon Pacheco & 74 \\
\hline 3 & Av Antônio Thomaz Ferreira de Rezende & Av João Naves de Ávila & 46 \\
\hline 4 & Av Engenheiro Diniz & R Engenhendador Alexandrino Garcia & 25 \\
\hline 5 & Av Nicomedes Alves dos Santos & Av Rondon Pacheco & 22 \\
\hline 6 & Av Belarmino Cotta Pacheco & Av João Naves de Ávila & 22 \\
\hline 7 & Av Cesário Alvim & Av João Naves de Ávila & 16 \\
\hline 8 & Av Getúlio Vargas & Av Paes Leme & 16 \\
\hline 9 & Av João Naves de Ávila & Av João Pinheiro & 16 \\
\hline 10 & Av Afonso Pena & R Olegário Maciel & 15 \\
\hline 11 & Av Belarmino Cotta Pacheco & R Sebastião Rangel & 14 \\
\hline 12 & Av Engenheiro Diniz & Av Raulino Cotta Pacheco & 14 \\
\hline 13 & Av Antônio Thomaz Ferreira de Rezende & Av Quilombo dos Palmares & 14 \\
\hline 14 & Av João Naves de Ávila & Av Segismundo Pereira & 13 \\
\hline 15 & Av Belo Horizonte & R Rodrigues da Cunha & 13 \\
\hline 16 & Av João Pinheiro & R Duque de Caxias & 12 \\
\hline 17 & Av dos Municípios & Av Rondon Pacheco & 12 \\
\hline 18 & Av João Pinheiro & R Itumbiara & 11 \\
\hline 19 & Av Rondon Pacheco & R Augusto César & 11 \\
\hline 20 & Av. Araguari & R Rodrigues da Cunha & 11 \\
\hline \hline & & & 10 \\
\hline
\end{tabular}

Org: BERNARDINO, A.R., 2006.

Fonte: SETTRAN, 2002. 
d) os vinte cruzamentos com maior número de acidentes, 2003

Quadro 32 - Os vinte cruzamentos com maior número de ocorrências de acidentes de trânsito, ano 2003, Uberlândia

\begin{tabular}{|c|l|l|c||}
\hline & Via Principal & Interseção & $\begin{array}{c}\mathbf{N}^{\circ} . \\
\text { Acidentes }\end{array}$ \\
\hline 1 & Av João Naves de Ávila & Av Rondon Pacheco & 96 \\
\hline 2 & Av Antônio Thomaz F.de Rezende & Av Comendador Alexandrino Garcia & 26 \\
\hline 3 & Av Nicomedes Alves dos Santos & Av Rondon Pacheco & 26 \\
\hline 4 & Av Floriano Peixoto & Av João Naves de Ávila & 25 \\
\hline 5 & Av Aspirante Mega & Av Getúlio Vargas & 24 \\
\hline 6 & Av Rondon Pacheco & R General Osório & 23 \\
\hline 7 & Av João Naves de Ávila & Av Segismundo Pereira & 22 \\
\hline 8 & Av Belarmino Cotta Pacheco & Av João Naves de Ávila & 20 \\
\hline 9 & Av Silvio Rugani & Av Uirapuru & 18 \\
\hline 10 & Av Cesário Alvim & Av João Naves de Ávila & 16 \\
\hline 11 & Av dos Municípios & Av Rondon Pacheco & 16 \\
\hline 12 & Av Floriano Peixoto & R Tenente Virmondes & 14 \\
\hline 13 & Av João Pessoa & Av João Pinheiro & 14 \\
\hline 14 & Av João Pinheiro & R Cel Antônio Alves Pereira & 13 \\
\hline 15 & Av João Pinheiro & R Goiás & 13 \\
\hline 16 & Av João Pinheiro & R Duque de Caxias & 13 \\
\hline 17 & Av Afonso Pena & R Tenente Virmondes & 12 \\
\hline 18 & Av Araguari & R Padre Pio & 12 \\
\hline 19 & Av Engenheiro Diniz & R Rodrigues da Cunha & 12 \\
\hline 20 & Av Floriano Peixoto & R Duque de Caxias & 12 \\
\hline \hline
\end{tabular}

Org: BERNARDINO, A.R., 2006.

Fonte: SETTRAN, 2003. 
e) os vinte cruzamentos com maior número de acidentes, 2004

Quadro 33 - Os vinte cruzamentos com maior número de ocorrências de acidentes de trânsito, ano 2004, Uberlândia

\begin{tabular}{|c|l|l|c|}
\hline & Via Principal & Interseção 1 & $\begin{array}{c}\mathbf{N}^{\circ} . \\
\text { Acidentes }\end{array}$ \\
\hline 1 & João Naves de Ávila & Rondon Pacheco & 134 \\
\hline 2 & Nicomedes Alves dos Santos & Rondon Pacheco & 50 \\
\hline 3 & Floriano Peixoto & João Naves de Ávila & 32 \\
\hline 4 & Antonio Thomaz F. de Rezende & Comendador Alexandrino Garcia & 27 \\
\hline 5 & João Naves de Ávila & Segismundo Pereira & 25 \\
\hline 6 & João Pessoa & João Pinheiro & 23 \\
\hline 7 & Aspirante Mega & Getúlio Vargas & 22 \\
\hline 8 & Augusto César & Rondon Pacheco & 21 \\
\hline 9 & Belarmino Cotta Pacheco & João Naves de Ávila & 21 \\
\hline 10 & Dos Municípios & Rondon Pacheco & 21 \\
\hline 11 & Anselmo Alves dos Santos & João Naves de Ávila & 20 \\
\hline 12 & Araguari & Padre Pio & 20 \\
\hline 13 & João Naves de Ávila & João Pinheiro & 18 \\
\hline 14 & Duque de Caxias & João Pinheiro & 17 \\
\hline 15 & Francisco Galassi & Liberdade & 17 \\
\hline 16 & João Naves de Ávila & Modesta Maria & 17 \\
\hline 17 & João Pinheiro & Tenente Virmondes & 17 \\
\hline 18 & Belo Horizonte & Rodrigues da Cunha & 16 \\
\hline 19 & Cesário Alvim & João Naves de Ávila & 16 \\
\hline 20 & Cipriano Del Fávero & João Pessoa & 15 \\
\hline
\end{tabular}

Org: BERNARDINO, A.R., 2006.

Fonte: SETTRAN, 2004. 


\section{3 - Espacialização dos acidentes de trânsito considerando os números mais altos de UPS - ano de 2000 a 2004, Uberlândia}

Por meio dos números de UPS instituídos pelo DENATRAN utilizaram-se, para selecionar as vinte vias ou segmentos, os vinte trechos e os vinte cruzamentos ou pontos que registraram os números mais altos de UPS, considerando todos os acidentes ocorridos nos segmentos viários, baseados na disponibilidade do banco de dados da SETTRAN, uma vez que este indica a soma da severidade de todos os acidentes ocorridos para cada via, cada trecho e cada cruzamento.

Mesmo analisando os números absolutos dos registros dos acidentes de trânsito, é dada também relevância aos números de UPS, tendo em vista que este índice traça o perfil do local em questão, relativos à gravidade dos danos dos eventos ocorridos, além de serem duas bases diferentes de análise para comparação. A UPS indica, em números, os danos ocorridos; se somente danos materiais, se vitimas leves ou vitimas graves e/ou mortos. Para cada uma dessas variáveis correlacionadas há um número (cf. capítulo 2), que se soma a todos os acidentes que ocorreram no local, no período em questão, que, assim, determinam os números de UPS para cada via, cada trecho e cada cruzamento.

Esses dados foram espacializados para os anos de 2000 a 2004, como os realizados para o número absoluto de acidentes de trânsito, visando a uma leitura de verificação dos segmentos viários com números de UPS mais altos, por meio dos quais, foram selecionados e identificados as vinte vias, os vinte trechos e os vinte cruzamentos que aparecem nesta análise. 
3.3.1 - Apresentação das vias com números de UPS mais altos dos acidentes de trânsito para os anos de 2000 a 2004 e sua espacialização

Nos quadros $34,35,36,37$ e 38 , constam as vinte vias com os números mais altos de UPS dos acidentes de trânsito e seus logradouros, além da sua espacialização apresentada nos mapas 21, 22, 23, 24 e 25.

Observou-se, assim, que as vias de maior número de acidentes (cf. item 3.2.1) são as mesmas que se apresentam como as que possuem os números mais altos de UPS, a saber: a Av. João Naves de Ávila, a Av. Rondon Pacheco, a Av. Floriano Peixoto e a Av. Afonso Pena. Salienta-se que no ano de 2004 as BR365/BR-452/BR-050 surgem dentre as principais, sendo que as duas últimas vias citadas desaparecem. Esta revelação pode ser justificada devido a intervenções feitas nas duas avenidas - não comprovadas - , Floriano Peixoto e Afonso Pena, cujo resultado das ações foi a redução das ocorrências de acidentes, e, por outro lado, alguma intervenção realizada nas rodovias no percurso que se insere na malha urbana pode ter sido relevante para as ocorrências de trânsito surgirem e situarem-nas na quarta posição dentre as principais para o ano de 2004 (cf. quadro 38 e mapa 25).

Nota-se que, novamente, os dados do ano de 2001 não revelam coerência, deixando de considerá-los na comparação aos demais (cf. capítulo 2). 
a) as vinte vias com os números mais altos de UPS, 2000

Quadro 34 - As vinte vias com os números mais altos de UPS dos acidentes de trânsito, ano 2000, Uberlândia

\begin{tabular}{|c|c|c|}
\hline & Via Principal & No UPS \\
\hline 1 & João Naves de Ávila & 578 \\
\hline 2 & Rondon Pacheco & 475 \\
\hline 3 & Afonso Pena & 389 \\
\hline 4 & Floriano Peixoto & 374 \\
\hline 5 & Cesário Alvim & 290 \\
\hline 6 & Getúlio Vargas & 280 \\
\hline 7 & Duque de Caxias & 188 \\
\hline 8 & Belarmino Cotta Pacheco & 188 \\
\hline 9 & João Pinheiro & 184 \\
\hline 10 & Segismundo Pereira & 178 \\
\hline 11 & Antonio Thomaz Ferreira de Rezende & 160 \\
\hline 12 & Brasil & 142 \\
\hline 13 & Raulino Cotta Pacheco & 133 \\
\hline 14 & Nicomedes Alves dos Santos & 132 \\
\hline 15 & Indianópolis & 119 \\
\hline 16 & João Pessoa & 115 \\
\hline 17 & Monsenhor Eduardo & 105 \\
\hline 18 & Tupaciguara & 104 \\
\hline 19 & Sebastião Rangel & 103 \\
\hline 20 & Anselmo Alves dos Santos & 91 \\
\hline
\end{tabular}

Org: BERNARDINO, A.R., 2006.

Fonte: SETTRAN, 2005. 
b) as vinte vias com os números mais altos de UPS, 2001

Quadro 35 - As vinte vias com os números mais altos de UPS dos acidentes de trânsito, Uberlândia, 2001

\begin{tabular}{|c|l|c|}
\hline & Via Principal & No UPS \\
\hline 1 & Av Getúlio Vargas & 219 \\
\hline 2 & Av Engenheiro Diniz & 128 \\
\hline 3 & Av Fernando Vilela & 124 \\
\hline 4 & Av Antonio Thomaz Ferreira de Rezende & 118 \\
\hline 5 & Av Aspirante Mega & 103 \\
\hline 6 & Av Vasconcelos Costa & 101 \\
\hline 7 & Av Cesário Crosara & 99 \\
\hline 8 & Av Araguari & 95 \\
\hline 9 & Av Monsenhor Eduardo & 84 \\
\hline 10 & Av Rondon Pacheco & 83 \\
\hline 11 & Av Nicomedes Alves Dos Santos & 81 \\
\hline 12 & Av José Fonseca E Silva & 80 \\
\hline 13 & Av Brigadeiro Sampaio & 76 \\
\hline 14 & Av Constelação & 74 \\
\hline 15 & Av Comendador Alexandrino Garcia & 74 \\
\hline 16 & Av João Pinheiro & 72 \\
\hline 17 & Av Paes Leme & 69 \\
\hline 18 & Av Paulo Roberto Cunha Santos & 61 \\
\hline 19 & Av Raulino Cotta Pacheco & 59 \\
\hline 20 & Av Belo Horizonte & 57 \\
\hline
\end{tabular}

Org: BERNARDINO, A.R., 2006.

Fonte: SETTRAN, 2005. 
c) as vinte vias com os números mais altos de UPS, 2002

Quadro 36 - As vinte vias com os números mais altos de UPS dos acidentes de trânsito, ano de 2002, Uberlândia

\begin{tabular}{|c|c|c|}
\hline & Via Principal & $\mathbf{N}^{\circ}$ UPS \\
\hline 1 & Av João Naves de Ávila & 962 \\
\hline 2 & Av Floriano Peixoto & 597 \\
\hline 3 & Av Rondon Pacheco & 597 \\
\hline 4 & Av Afonso Pena & 532 \\
\hline 5 & Av João Pinheiro & 426 \\
\hline 6 & Av Getúlio Vargas & 345 \\
\hline 7 & Av Cesário Alvim & 342 \\
\hline 8 & Av Segismundo Pereira & 284 \\
\hline 9 & Av Brasil & 218 \\
\hline 10 & Av Antônio Thomaz Ferreira de Rezende & 215 \\
\hline 11 & Av José Fonseca e Silva & 201 \\
\hline 12 & Av Araguari & 200 \\
\hline 13 & Av Engenheiro Diniz & 195 \\
\hline 14 & Av Comendador Alexandrino Garcia & 191 \\
\hline 15 & Av Belarmino Cotta Pacheco & 190 \\
\hline 16 & Av Fernando Vilela & 188 \\
\hline 17 & Av Nicomedes Alves dos Santos & 184 \\
\hline 18 & Av Monsenhor Eduardo & 170 \\
\hline 19 & Av Aspirante Mega & 170 \\
\hline 20 & Av Cesário Crosara & 169 \\
\hline
\end{tabular}

Org: BERNARDINO, A.R., 2006.

Fonte: SETTRAN, 2002. 
d) as vinte vias com os números mais altos de UPS, 2003

Quadro 37 - As vinte vias com os números mais altos de UPS dos acidentes de trânsito no ano de 2003, Uberlândia

\begin{tabular}{|c|l|c|}
\hline & Via Principal & No UPS \\
\hline 1 & Av João Naves de Ávila & 953 \\
\hline 2 & Av Rondon Pacheco & 652 \\
\hline 3 & Av Floriano Peixoto & 591 \\
\hline 4 & Av Afonso Pena & 558 \\
\hline 5 & Av João Pinheiro & 458 \\
\hline 6 & Av Getúlio Vargas & 345 \\
\hline 7 & Av Monsenhor Eduardo & 295 \\
\hline 8 & Av Aspirante Mega & 276 \\
\hline 9 & Av Segismundo Pereira & 269 \\
\hline 10 & Av Cesário Alvim & 262 \\
\hline 11 & Av Anselmo Alves dos Santos & 248 \\
\hline 12 & Av Brasil & 233 \\
\hline 13 & Av José Fonseca e Silva & 223 \\
\hline 14 & Av Belarmino Cotta Pacheco & 197 \\
\hline 15 & Av Vasconcelos Costa & 192 \\
\hline 16 & Av Fernando Vilela & 190 \\
\hline 17 & Av João Pessoa & 183 \\
\hline 18 & Av Antônio Thomaz Ferreira de Rezende & 177 \\
\hline 19 & Av José Andraus Gassani & 162 \\
\hline 20 & Av Engenheiro Diniz & 142 \\
\hline
\end{tabular}

Org: BERNARDINO, A.R., 2006.

Fonte: SETTRAN, 2003. 
e) as vinte vias com os números mais altos de UPS, 2004

Quadro 38 - As vinte vias com os números mais altos de UPS dos acidentes de trânsito para o ano de 2004, Uberlândia

\begin{tabular}{|c|c|c|}
\hline & Via Principal & $\mathbf{N}^{\circ}$ UPS \\
\hline 1 & Rondon Pacheco & 227 \\
\hline 2 & João Naves de Ávila & 105 \\
\hline 3 & BR-365 \BR-050 \Br-452 & 90 \\
\hline 4 & Anselmo Alves dos Santos & 78 \\
\hline 5 & Getúlio Vargas & 71 \\
\hline 6 & Profa. Minervina Cândida de Oliveira & 49 \\
\hline 7 & Nicomedes Alves dos Santos & 45 \\
\hline 8 & Neuza Rezende & 37 \\
\hline 9 & Jose Andraus Gassani & 36 \\
\hline 10 & José Fonseca e Silva & 36 \\
\hline 11 & Segismundo Pereira & 34 \\
\hline 12 & Antonio Thomaz Ferreira Rezende & 28 \\
\hline 13 & Argemiro Evangelista Ferreira & 26 \\
\hline 14 & Pará & 26 \\
\hline 15 & Antônio Jorge Isaac & 24 \\
\hline 16 & Seme Simão & 23 \\
\hline 17 & Rafael Marino Neto & 22 \\
\hline 18 & Estrada P/ Sucupira & 21 \\
\hline 19 & Francisco Galassi & 21 \\
\hline 20 & Imbaúbas & 21 \\
\hline
\end{tabular}

Org: BERNARDINO, A.R., 2006.

Fonte: SETTRAN, 2004. 
3.3.2 - Apresentação dos trechos com números de UPS mais altos dos acidentes de trânsito para os anos de 2000 a 2004 e sua espacialização

Nos quadros 39, 40, 41, 42 e 43, apresenta-se a identificação dos trechos com números mais altos de UPS dos acidentes de trânsito com seus logradouros e seus respectivos números de acidentes ocorridos nos anos de 2000 a 2004, hierarquizados em ordem decrescente.

Na seqüência, dispõe-se a espacialização (cf. mapas 26, 27, 28, 29 e 30) dos vinte principais trechos com números mais altos de UPS dos acidentes de trânsito, cujos números indicados correspondem aos dos quadros 39, 40, 41, 42 e 43 , respectivamente.

Observa-se que outras identificações de trechos que compreendem a via principal, Av. João Naves de Ávila, constam nas primeiras posições da hierarquia, denotando-a, novamente, como a principal via quando a análise é feita referente aos números mais altos de UPS (cf. quadros 39 a 43).

Quando efetuada a visualização da espacialização dos acidentes pelos números de UPS (mapas 26 a 30), nota-se que a distribuição torna-se mais dispersa em relação à dos trechos da análise referente à freqüência dos acidentes que ocorrem de forma mais intensa na área central da cidade.

A partir dessa leitura, constata-se que a severidade dos acidentes aumenta quando os registros das ocorrências localizam-se fora da área central. Primeiro, pela possibilidade de exceder a velocidade e, outra, que é pertinente a essa, pela falta de atenção, inconscientemente, por não haver excessos de circulação de pessoas e veículos agrupados, como é no setor central.

Reforça-se que os trechos da Av. Rondon Pacheco que se destacam no ano de 2000 , não mais aparecem nos outros anos, podendo constatar também 
que a instalação de equipamentos de fiscalização eletrônica nesta via foi positiva, em se tratando tanto do número de acidentes quanto à sua severidade (cf. quadros 39 a 43).

a) os vinte trechos com os números mais altos de UPS, 2000

Quadro 39 - Os vinte trechos com os números mais altos de UPS dos acidentes de trânsito no ano de 2000, Uberlândia

\begin{tabular}{||c|l|l|l|c|}
\hline \hline & Via Principal & Interseção 1 & Interseção 2 & No UPS \\
\hline 1 & Av. João Naves de Ávila & Luiza de Jesus & Ubiratan Honório deCastro & 52 \\
\hline 2 & Av. Rondon Pacheco & Olegário Maciel & Duque de Caxias & 20 \\
\hline 3 & Av. Rondon Pacheco & Quintino Bocaiúva & Cel Antônio Alves Pereira & 20 \\
\hline 5 & Av. Rondon Pacheco & Maria Vilela Ribeiro & José de Moraes & 14 \\
\hline 6 & Av. Antônio ThomazF. Rez. & Farroupilhas & Olegário Maciel & 14 \\
\hline 7 & Av. Rondon Pacheco & Prof. Mário Porto & Sabinadas & 14 \\
\hline 8 & Av. José Andraus Gassani & Afonso Egydio De Souza & Wandelvart Faria Marquez & 13 \\
\hline 9 & Av. Brasil & Pedro Quirino Da Silva & República do Piratini & 12 \\
\hline 10 & Av. Genarino Cazabona & Orlando Naves & Luiz Antônio Neves & 11 \\
\hline 11 & Av. João Pessoa & Indianópolis & Cesário Crosara & 11 \\
\hline 12 & Av. Jerônimo Jose Alves & São Sebastião & Felipe Calixto Milken & 11 \\
\hline 13 & R. Monte Carmelo & Raulino Cotta Pacheco & Bueno Brandão & 11 \\
\hline 14 & Av. Floriano Peixoto & Buriti Alegre & Ivaldo Alves Nascimento & 9 \\
\hline 15 & Av. Afonso Pena & Olegário Maciel & Santos Dumont & 9 \\
\hline 16 & Av. Jose Fonseca e Silva & Opala & Aspirante Mega & 9 \\
\hline 17 & Av. João Naves de Ávila & Belarmino Cotta Pacheco & Manoel dos Santos & 8 \\
\hline 18 & Av. Getúlio Vargas & General Canabarro & Itajubáa & 8 \\
\hline 19 & Av. Rondon Pacheco & Rezende & Joaquim Cordeiro & 8 \\
\hline 20 & Av. Com. Alexand. Garcia & Claudemiro José Souza & Alagoas & 8 \\
\hline \hline
\end{tabular}

Org: BERNARDINO, A.R., 2006.

Fonte: SETTRAN, 2000. 
b) os vinte trechos com os números mais altos de UPS, 2001

Quadro 40 - Os vinte trechos com os números mais altos de UPS dos acidentes de trânsito no ano de 2001, Uberlândia

\begin{tabular}{|c|c|c|c|c|}
\hline & Via Principal & Interseção 1 & Interseção 2 & No UPS \\
\hline 1 & Av Taylor Silva & R Garibalde Alves Vieira & Av do Carnaval & 11 \\
\hline 2 & Av Uirapuru & R José de Oliveira Pinto & $\mathrm{R}$ dos Pardais & 11 \\
\hline 3 & Av Araguari & Pça Adalberto R. da Cunha & Av Paes Leme & 11 \\
\hline 4 & Av Cel José T. Carneiro & R Luiz Ferreira Lima & R Beira Rio & 11 \\
\hline 5 & Av Constelação & Av Paulo Roberto C. Santos & R Baurú & 11 \\
\hline 6 & Av João Pessoa & R Monte Carmelo & R Indianópolis & 11 \\
\hline 7 & Av Cesário Crosara & R Ordália Carneiro Oliveira & R Douglas Andreani & 10 \\
\hline 8 & Av Getúlio Vargas & R Duque de Caxias & R Olegário Maciel & 10 \\
\hline 9 & Av Fernando Vilela & R Vieira Gonçalves & R Carmo Gifoni & 9 \\
\hline 10 & Av Indaiá & R Do Bancário & R Do Estudante & 9 \\
\hline 11 & Av Raulino Cotta Pacheco & Av Fernando Vilela & R Prof. João Basílio & 9 \\
\hline 12 & R Engenheiro Azeli & R Monte Carmelo & $\mathrm{R}$ Indianópolis & 9 \\
\hline 13 & Av João Pinheiro & R Bernardo Guimarães & Pça Adolfo Fonseca & 8 \\
\hline 14 & Av Francisco Galassi & Av das Américas & R Cruzeiro & 8 \\
\hline 15 & Av Paes Leme & R Engenheiro Azeli & R Eduardo Marquez & 8 \\
\hline 16 & Av Paulo Roberto C.Santos & R Dr Luiz Antonio Waack & R David Canabarro & 8 \\
\hline 17 & R Bernardo Guimarães & Av Floriano Peixoto & Av Afonso Pena & 8 \\
\hline 18 & R Do Advogado & R do Odontólogo & R do Garçon & 8 \\
\hline 19 & Av Afrânio R. da Cunha & R Pio Alves Barbosa & R João Tobias & 7 \\
\hline 20 & Av.Antonio Thomaz F. Rez. & Av Farroupilhas & Av Sabinadas & 7 \\
\hline
\end{tabular}

Org: BERNARDINO, A.R., 2006.

Fonte: SETTRAN, 2001. 
c) os vinte trechos com os números mais altos de UPS, 2002

Quadro 41 - Os vinte trechos com os números mais altos de UPS dos acidentes de trânsito no ano de 2002, Uberlândia

\begin{tabular}{|c|l|l|l|c||}
\hline \hline & Via Principal & Interseção 1 & Interseção 2 & N$^{\circ}$ UPS \\
\hline 1 & Av João Naves de Avila & R Cassimiro de Abreu & Av. São Francisco de Assis & 24 \\
\hline 2 & Av Silvio Rugani & R Tomé de Souza & R Nilo Peçanha & 19 \\
\hline 3 & Av Getúlio Vargas & R General Canabarro & R Itajubá & 16 \\
\hline 4 & Av Angelino Favato & Ala Antonio Carlos V. Cunha & Al Antônio Ovídio & 16 \\
\hline 5 & Av Cleanto Vieira Gonçalves & R Rubens Cazabona & R Treze de Maio & 16 \\
\hline 6 & Av Floriano Peixoto & R Buriti Alegre & R Itumbiara & 15 \\
\hline 7 & Av Rondon Pacheco & R Cel Antônio Alves Pereira & R Raphael Lourenço & 15 \\
\hline 8 & Av Seme Simão & Al Mãe Menininha Cantuá & Al Antônio Carlos V.Cunha & 15 \\
\hline 9 & Av Taylor Silva & Av Do Carnaval & Av Clássica & 15 \\
\hline 10 & R Angelo Cunha & R Altivo Ferreira Batista & R América Viana & 15 \\
\hline 11 & Av Afonso Pena & R Duque De Caxias & R Machado De Assis & 14 \\
\hline 12 & Av Getúlio Vargas & R Tenente Virmondes & R Machado De Assis & 14 \\
\hline 13 & Av João Naves de Ávila & Av Belarmino Cotta Pacheco & Av Manoel Dos Santos & 14 \\
\hline 14 & Av João Naves de Ávila & Av Floriano Peixoto & Av Cesário Alvim & 14 \\
\hline 15 & Av Brigadeiro Sampaio & R Monlevade & R Newton F. Arantes & 14 \\
\hline 16 & Av Afonso Pena & R Tenente Virmondes & R Quintino Bocaiúva & 13 \\
\hline 17 & Av Afonso Pena & R Quintino Bocaiúva & R Cel Antônio A. Pereira & 13 \\
\hline 18 & Av Afonso Pena & R Abdalla Haddad & R Martinesia & 13 \\
\hline 19 & Antonio Thomaz F. Rezende & Av Farroupilhas & Av Sabinadas & 13 \\
\hline 20 & Av Taylor Silva & Av Congado & R Renato José Luiz & 13 \\
\hline
\end{tabular}

Org: BERNARDINO, A.R., 2006.

Fonte: SETTRAN, 2002. 
d) os vinte trechos com os números mais altos de UPS, 2003

Quadro 42 - Os vinte trechos com os números mais altos de UPS dos acidentes de trânsito no ano de 2003, Uberlândia

\begin{tabular}{|r|l|l|l|c||}
\hline \hline & Via Principal & Interseção 1 & Interseção 2 & N$^{\circ}$ UPS \\
\hline 1 & Av João Pessoa & Av Afonso Pena & Av João Pinheiro & 61 \\
\hline 2 & Antonio Thomaz F. Rezende & Av Visconde de Mauá & Av Farroupilhas & 33 \\
\hline 3 & Av Anselmo A. dos Santos & R Licydio Paes & R Armando Tucci & 32 \\
\hline 4 & Av Afonso Pena & R Tenente Virmondes & R Quintino Bocaiúva & 30 \\
\hline 5 & Av Cleanto V. Gonçalves & R Rubens Cazabona & R Treze de Maio & 28 \\
\hline 6 & Av João Naves de Ávila & Av Floriano Peixoto & Av Cesário Alvim & 27 \\
\hline 7 & Av João Naves de Ávila & Av Rio Branco & Av Rondon Pacheco & 25 \\
\hline 8 & Av João Naves de Ávila & R Maracanã & Av João Mendes & 21 \\
\hline 9 & Av João Naves de Ávila & R Cassimiro de Abreu & R Francisco B. Assis & 19 \\
\hline 10 & Av João Naves de Ávila & R Luiza de Jesus & Av Ubiratan H. Castro & 19 \\
\hline 11 & Av Jaime de Barros & Av Geraldo Abrão & R Antônio B. Rodrigues & 18 \\
\hline 12 & Av João Naves de Ávila & Av Manoel dos Santos & Av Vitalino R. do Carmo & 17 \\
\hline 13 & Av João Pinheiro & R Machado de Assis & R Tenente Virmondes & 17 \\
\hline 14 & Av Benjamin Magalhães & R Nicarágua & R Venezuela & 17 \\
\hline 15 & Av João Naves de Ávila & Av José R. Costa & Av Jerônimo M. Santos & 17 \\
\hline 16 & Av Vasconcelos Costa & R Arthur Bernardes & Av Raulino C. Pacheco & 17 \\
\hline 17 & Av João Naves de Ávila & Av Rondon Pacheco & Av Anselmo A. dos Santos & 16 \\
\hline 18 & Av Aspirante Mega & Av Brigadeiro Sampaio & R das Jaqueiras & 16 \\
\hline 19 & Av Continental & R Síria & Av Dinamarca & 16 \\
\hline 20 & Av Afonso Pena & R Machado de Assis & R Tenente Virmondes & 15 \\
\hline \hline
\end{tabular}

Org: BERNARDINO, A.R., 2006.

Fonte: SETTRAN, 2003. 
d) os vinte trechos com os números mais altos de UPS, 2004

Quadro 43 - Os vinte trechos com os números mais altos de UPS dos acidentes de trânsito no ano de 2004, Uberlândia

\begin{tabular}{|c|c|c|c|c|}
\hline & Via Principal & Interseção 1 & Interseção 2 & No UPS \\
\hline 1 & Av.João Naves de Ávila & Av.Cesário Alvim & Av.Floriano Peixoto & 42 \\
\hline 2 & Av.Afonso Pena & R. Quintino Bocaiúva & R. Tenente Virmondes & 25 \\
\hline 3 & Av.João Pessoa & Av.Afonso Pena & Av.João Pinheiro & 22 \\
\hline 4 & Av.Afonso Pena & R. Abdalla Haddad & R. Martinésia & 19 \\
\hline 5 & Av.Getúlio Vargas & R. General Canabarro & R. Itajubá & 16 \\
\hline 6 & Av.João Pinheiro & R. Olegário Maciel & R. Santos Dumont & 15 \\
\hline 7 & Antonio Thomaz F. Rezende & Av.Farroupilhas & Av.Sabinadas & 15 \\
\hline 8 & Cleanto Vieira Gonçalves & Clarimundo José Cardoso & RGeraldo C. Nogueira & 15 \\
\hline 9 & Antonio Thomaz F. Rezende & Av.Cabanadas & R. Garcia Lorca & 14 \\
\hline 10 & Antonio Thomaz F. Rezende & Av.Farroupilhas & R. Visconde de Mauá & 14 \\
\hline 11 & Av.Imbaúbas & R. Da Secretária & R. Do Bancário & 13 \\
\hline 12 & Av.Vasconcelos Costa & R. Carmo Gifoni & R. Vieira Gonçalves & 13 \\
\hline 13 & Cel José Teófilo Carneiro & Av.Beira Rio & R. Luiz Ferreira Lima & 12 \\
\hline 14 & Av.Floriano Peixoto & R. Olegário Maciel & R. Santos Dumont & 12 \\
\hline 15 & Av.Getúlio Vargas & R. Jose Bonifácio & R. Vital Macedo & 12 \\
\hline 16 & Pça. Tubal Vilela & R. Duque de Caxias & R. Olegário Maciel & 12 \\
\hline 17 & Com. Alexandrino Garcia & R. José Rezende Santos & R. Pde Américo Ceppi & 12 \\
\hline 18 & R. Duque de Caxias & Av.Afonso Pena & Av.João Pinheiro & 11 \\
\hline 19 & Av.Afonso Pena & R. Cruzeiro dos Peixotos & R. Roosevelt Oliveira & 11 \\
\hline 20 & Av.Vasconcelos Costa & R. Bueno Brandão & R. Melo Viana & 11 \\
\hline
\end{tabular}

Org: BERNARDINO, A.R., 2006.

Fonte: SETTRAN, 2004. 
3.3.3 - Apresentação dos cruzamentos com números de UPS mais altos dos acidentes de trânsito para os anos de 2000 a 2004 e sua espacialização

A espacialização dos vinte cruzamentos de números mais altos de UPS dos acidentes de trânsito pode ser observada nos mapas 31,32 , 33, 34 e 35, no qual os números indicados correspondem aos dos quadros $44,45,46,47$ e 48 , respectivamente.

Os cruzamentos identificados que apresentam os números mais altos de UPS dos acidentes por ano incluem as avenidas principais da cidade, aquelas em que são permitidos dois sentidos de direção em seus fluxos, além das que possuem retornos ou são interrompidas por outras. Assim sendo, é considerada de maior possibilidade a ocorrência dos acidentes devido aos pontos de articulação que formam, proporcionando conflitos entre veículos.

Verifica-se que a distribuição dos acidentes, considerando os números de UPS, localiza-se não somente na área central, mas dispersam pela área urbana, levando a entender que a severidade dos acidentes, principalmente referente aos cruzamentos, modifica a distribuição dos pontos principais de freqüência das ocorrências.

Com relação ao cruzamento da Av. João Naves de Ávila com Av. Rondon Pacheco, este aparece com relevância, tanto para os números absolutos, quanto para os números de UPS dos acidentes de trânsito.

Nota-se, na visualização da área que abrange os cruzamentos de números mais altos de UPS, para os anos analisados, que esta se encontra localizada no setor central e no entorno, uma vez que a distribuição espacial é homogênea para o período, com exceção do ano de 2001. Especificadamente, os cruzamentos se alteram devido a alguma intervenção local ou do entorno que atinge o movimento do cruzamento em questão. 
Conforme explicações no capítulo 2, sobre os dados incoerentes do ano de 2001, a visualização espacial oferece mais um detalhe referente ao Batalhão da Polícia em que não foram coletados e tabulados os dados dos acidentes de trânsito.

Salienta-se que ao identificar o batalhão que não foi analisado, dentre os três locais de coleta dos B.O., o $17^{\circ}$. Batalhão da Polícia é o que registra as ocorrências que abrangem o setor sudeste. Assim, as vias principais de referência desse setor que são as Av. João Naves de Ávila, Av. Segismundo Pereira e Av. Belarmino Cotta Pacheco, não foram visualizadas na espacialização dos dados, o que pode justificar a ausência das mesmas.

a) os vinte cruzamentos com os números mais altos de UPS, 2000

Quadro 44 - Os vinte cruzamentos com os números mais altos de UPS dos acidentes de trânsito no ano de 2000, Uberlândia

\begin{tabular}{|c|l|l|c|}
\hline \hline & Via Principal & Interseção & No UPS \\
\hline 1 & Av.João Naves de Ávila & Av.Rondon Pacheco & 140 \\
\hline 2 & Av.Nicomedes Alves dos Santos & Av.Rondon Pacheco & 71 \\
\hline 3 & Av.Cesário Alvim & Av.João Naves de Ávila & 45 \\
\hline 4 & Av.Belarmino Cotta Pacheco & R. Sebastião Rangel & 38 \\
\hline 5 & Av.Afonso Pena & Av.João Pessoa & 28 \\
\hline 6 & Av.Afonso Pena & R. Prata & 28 \\
\hline 7 & R. Duque de Caxias & Av.São Francisco de Assis & 27 \\
\hline 8 & R. Duque de Caxias & Av.João Pinheiro & 26 \\
\hline 9 & Av.Cipriano Del Fávero & Av.João Pessoa & 25 \\
\hline 10 & Av.Fernando Vilela & R. Vieira Gonçalves & 25 \\
\hline 11 & R. Belém & Av.Rondon Pacheco & 24 \\
\hline 12 & R.Sebastião Rangel & Av.Segismundo Pereira & 24 \\
\hline 13 & R. Antônio Crescêncio & Av.Floriano Peixoto & 23 \\
\hline 14 & R. Hidelbrando Oliva & Av.Segismundo Pereira & 22 \\
\hline 15 & Av.Getúlio Vargas & Av.Paes Lemes & 21 \\
\hline 16 & Av.Antonio Thomaz F. de Rezende & R. Quilombo dos Palmares & 21 \\
\hline 17 & Av.Nordau Gonçalves de Melo & Av.Segismundo Pereira & 21 \\
\hline 18 & Av.Paes Lemes & Av.Vasconcelos Costa & 21 \\
\hline 19 & Av.João Naves de Ávila & Av.Segismundo Pereira & 20 \\
\hline 20 & Av.Floriano Peixoto & R. Santos Dumont & 20 \\
\hline \hline
\end{tabular}

Org: BERNARDINO, A.R., 2006.

Fonte: SETTRAN, 2000. 
b) os vinte cruzamentos com os números mais altos de UPS, 2001

Quadro 45 - Os vinte cruzamentos com os números mais altos de UPS dos acidentes de trânsito no ano de 2001, Uberlândia

\begin{tabular}{|c|l|l|c||}
\hline & Via Principal & Interseção & N$^{\circ}$ UPS \\
\hline 1 & Av Antonio Thomaz Ferreira de Rezende & Av Comendador Alexandrino Garcia & 35 \\
\hline 2 & Av Engenheiro Diniz & R Engenheiro Azeli & 33 \\
\hline 3 & Av Brigadeiro Sampaio & Av Ipê & 27 \\
\hline 4 & Av Fernando Vilela & Av Marcos de Freitas Costa & 27 \\
\hline 5 & Av Getúlio Vargas & Av Marcos se Freitas Costa & 26 \\
\hline 6 & Av das Gameleiras & Av Imbaúbas & 22 \\
\hline 7 & Av Engenheiro Diniz & Av Raulino Cotta Pacheco & 21 \\
\hline 8 & Av Raulino Cotta Pacheco & Av Vasconcelos Costa & 19 \\
\hline 9 & Av Aspirante Mega & Av Getúlio Vargas & 18 \\
\hline 10 & R da Produção & R Virgílio Carrijo & 18 \\
\hline 11 & Av Paes Leme & R Tapuirama & 17 \\
\hline 12 & Av Fernando Vilela & R Rodrigues da Cunha & 17 \\
\hline 13 & Av Sacramento & R Arlindo Teixeira & 17 \\
\hline 14 & Av Indaiá & R da Secretária & 16 \\
\hline 15 & Av Comendador Alexandrino Garcia & Av Monsenhor Eduardo & 16 \\
\hline 16 & R das Mães & R Netuno & 16 \\
\hline 17 & Av José Fonseca E Silva & R Opala & 15 \\
\hline 18 & Av Fernando Vilela & Av João Pessoa & 14 \\
\hline 19 & Av Antônio Thomaz Ferreira de Rezende & R Neuza Magnino Cardoso & 14 \\
\hline 20 & Av Brigadeiro Sampaio & Av Marcos de Freitas Costa & 13 \\
\hline
\end{tabular}

Org: BERNARDINO, A.R., 2006.

Fonte: SETTRAN, 2001. 
c) os vinte cruzamentos com os números mais altos de UPS, 2002

Quadro 46 - Os vinte cruzamentos com os números mais altos de UPS dos acidentes de trânsito no ano de 2002, Uberlândia

\begin{tabular}{||c|l|l|c|}
\hline \hline & Via Principal & Interseção & No UPS \\
\hline 1 & Av João Naves de Ávila & Av Rondon Pacheco & 92 \\
\hline 2 & Av Floriano Peixoto & Av João Naves de Ávila & 67 \\
\hline 3 & Av Engenheiro Diniz & R Engenheiro Azeli & 64 \\
\hline 4 & Av Antônio Thomaz Ferreira Rezende & Av Comendador Alexandrino Garcia & 46 \\
\hline 5 & Av Afonso Pena & R Olegário Maciel & 44 \\
\hline 6 & Av Cesário Alvim & Av João Naves de Ávila & 40 \\
\hline 7 & Av Rondon Pacheco & Av Vitalino Rezende do Carmo & 38 \\
\hline 8 & Av Getúlio Vargas & Av Paes Leme & 37 \\
\hline 9 & Av Antônio Thomaz Ferreira Rezende & Av Quilombo Dos Palmares & 37 \\
\hline 10 & Av Belarmino Cotta Pacheco & R Sebastiao Rangel & 35 \\
\hline 11 & Av Araguari & R Rodrigues da Cunha & 34 \\
\hline 12 & Av João Naves de Ávila & Av João Pinheiro & 33 \\
\hline 13 & Av Rondon Pacheco & R Augusto Cesar & 32 \\
\hline 14 & Av Nicomedes Alves dos Santos & Av Rondon Pacheco & 31 \\
\hline 15 & Av Belarmino Cotta Pacheco & Av João Naves de Ávila & 31 \\
\hline 16 & Av Belarmino Cotta Pacheco & R Maria das Dores Dias & 29 \\
\hline 17 & Av Belo Horizonte & R Rodrigues da Cunha & 27 \\
\hline 18 & Av Cipriano Del Fávero & Av João Pessoa & 27 \\
\hline 19 & Av Afonso Pena & R Prata & 26 \\
\hline 20 & Av João Naves de Ávila & R Modesta Maria & 26 \\
\hline
\end{tabular}

Org: BERNARDINO, A.R., 2006.

Fonte: SETTRAN, 2002. 
d) os vinte cruzamentos com os números mais altos de UPS, 2003

Quadro 47 - Os vinte cruzamentos com os números mais altos de UPS dos acidentes de trânsito no ano de 2003, Uberlândia

\begin{tabular}{|r|l|l|c|}
\hline & Via Principal & Interseção & $N^{\circ}$ UPS \\
\hline 1 & Av João Naves de Ávila & Av Rondon Pacheco & 150 \\
\hline 2 & Av Antonio Thomaz Ferreira de Rezende & Av Com. Alexandrino Garcia & 69 \\
\hline 3 & Av Aspirante Mega & Av Getúlio Vargas & 69 \\
\hline 4 & Av João Naves de Ávila & Av Segismundo Pereira & 43 \\
\hline 5 & Av Nicomedes Alves dos Santos & Av Rondon Pacheco & 38 \\
\hline 6 & Av João Mendes & Av João Naves de Ávila & 37 \\
\hline 7 & Av Engenheiro Diniz & R Rodrigues da Cunha & 36 \\
\hline 8 & Av Monsenhor Eduardo & R Itumbiara & 35 \\
\hline 9 & Av Floriano Peixoto & Av João Naves de Ávila & 34 \\
\hline 10 & Av Cesário Alvim & Av João Naves de Ávila & 34 \\
\hline 11 & Av Marcos de Freitas Costa & Av Vasconcelos Costa & 34 \\
\hline 12 & Av Silvio Rugani & Av Uirapuru & 33 \\
\hline 13 & Av Araguari & R Padre Pio & 33 \\
\hline 14 & Av Afonso Pena & R Tenente Virmondes & 30 \\
\hline 15 & Av Mato Grosso & R Prata & 29 \\
\hline 16 & Av João Pinheiro & R Cel. Antonio Alves Pereira & 28 \\
\hline 17 & R Duque de Caxias & R Tamoios & 28 \\
\hline 18 & Av Araguari & R México & 27 \\
\hline 19 & R Antônio Vicente Ferreira & R do Economista & 27 \\
\hline 20 & Av Monsenhor Eduardo & R Prata & 27 \\
\hline \hline
\end{tabular}

Org: BERNARDINO, A.R., 2006.

Fonte: SETTRAN, 2003. 
e) os vinte cruzamentos com os números mais altos de UPS, 2004

Quadro 48 - Os vinte cruzamentos com os números mais altos de UPS dos acidentes de trânsito no ano de 2004, Uberlândia

\begin{tabular}{|c|l|l|c|}
\hline & Via pincipal & Interseção 1 & N$^{\circ}$ UPS \\
\hline 1 & Av. João Naves de Ávila & Av.Rondon Pacheco & 180 \\
\hline 2 & Av.Nicomedes Alves dos Santos & Av.Rondon Pacheco & 87 \\
\hline 3 & Av.Antonio Thomaz F. de Rezende & Av.Comendador Alexandrino Garcia & 55 \\
\hline 4 & Av.Araguari & R.Padre Pio & 47 \\
\hline 5 & Av.Floriano Peixoto & Av.João Naves de Ávila & 44 \\
\hline 6 & Av.João Pessoa & Av.João Pinheiro & 41 \\
\hline 7 & Av.Brigadeiro Sampaio & Av.Ipê & 40 \\
\hline 8 & Av.Aspirante Mega & Av.Getúlio Vargas & 39 \\
\hline 9 & Av.Francisco Galassi & Av.Liberdade & 38 \\
\hline 10 & Av.Benjamin Magalhães & Av.Europa & 36 \\
\hline 11 & Av.Cipriano Del Fávero & Av.João Pessoa & 35 \\
\hline 12 & Av.Nicomedes Alves dos Santos & Av.Rafael Marino Neto & 35 \\
\hline 13 & R. Augusto César & Av.Rondon Pacheco & 33 \\
\hline 14 & Av.João Naves de Ávila & Av.Segismundo Pereira & 31 \\
\hline 15 & Av.Dos Municípios & Av.Rondon Pacheco & 30 \\
\hline 16 & R. Duque de Caxias & Av.João Pinheiro & 29 \\
\hline 17 & Av.Aspirante Mega & Av.Imbaúbas & 29 \\
\hline 18 & Av.Cesário Alvim & Av.João Naves de Ávila & 28 \\
\hline 19 & Av.Araguari & Av.Marcos de Freitas Costa & 28 \\
\hline 20 & Av.Belarmino Cotta Pacheco & Av.João Naves de Ávila & 27 \\
\hline
\end{tabular}

Org: BERNARDINO, A.R., 2006.

Fonte: SETTRAN, 2004. 


\section{4 - Identificação das vias, dos trechos e dos cruzamentos críticos da área urbana de Uberlândia}

Os acidentes de tráfego como eventos, apesar de freqüentes sob o ponto de vista social, são somente observáveis após sua ocorrência, não sendo possível, portanto, reproduzí-los (MEIRELES, 1992). Dessa forma, reconhecemse os locais freqüentes de acidentes após o ocorrido e assim registrados.

Para a identificação das vias, trechos e cruzamentos considerados críticos, fez-se a média aritmética dos números de acidentes e de UPS a estes referentes, trabalhados por ano, e aqueles que estiveram acima da média alcançada foram identificados de situação crítica ou pontos críticos. Este procedimento foi realizado para os vinte segmentos selecionados e hierarquizados, de maior número de acidentes e de número de UPS mais altos, dos acidentes de trânsito. $O$ procedimento pode ser verificado a sua íntegra em BRASIL (2002).

Consideram-se importantes os segmentos selecionados do sistema viário para a visualização, que, a partir de seu conjunto, apresenta com mais clareza onde estão localizadas as situações críticas. Assim, tem-se, a seguir, a identificação das vias críticas referentes aos maiores números de acidentes de trânsito, bem como os números mais altos de UPS, além dos trechos críticos e dos cruzamentos ou pontos críticos para os anos analisados, de 2000 a 2004.

3.4.1 - Identificação das vias ou segmentos críticos, considerando os resultados das médias das vinte vias de maior número de acidentes de trânsito

As vias ou segmentos críticos do ano de 2000 , levando em conta o número maior de ocorrências de acidentes de trânsito, são aquelas até a sétima posição do quadro 19, pois apresentam números de acidentes acima de 78 , cujo limite foi dado pela média aritmética das vias selecionadas. 
As vias ou segmentos críticos do ano de 2001, considerando o número maior de ocorrências de acidentes de trânsito, são aquelas até a sétima posição do quadro 20 , pois apresentam números de acidentes acima de 45 , cujo limite foi dado pela média aritmética das vias selecionadas.

As vias ou segmentos críticos do ano de 2002, considerando o número maior de ocorrências de acidentes de trânsito, são aquelas até a sétima posição do quadro 21 , pois apresentam números de acidentes acima de 152 , cujo limite foi dado pela média aritmética das vias selecionadas.

As vias ou segmentos críticos do ano de 2003, considerando o número maior de ocorrências de acidentes de trânsito, são aquelas até a quinta posição do quadro 22, pois apresentam números de acidentes acima de 164, cujo limite foi dado pela média aritmética das vias selecionadas.

As vias ou segmentos críticos do ano de 2004, considerando o número maior de ocorrências de acidentes de trânsito, são aquelas até a sexta posição do quadro 23 , pois, apresentam números de acidentes acima de 23 , cujo limite foi dado pela média aritmética das vias selecionadas.

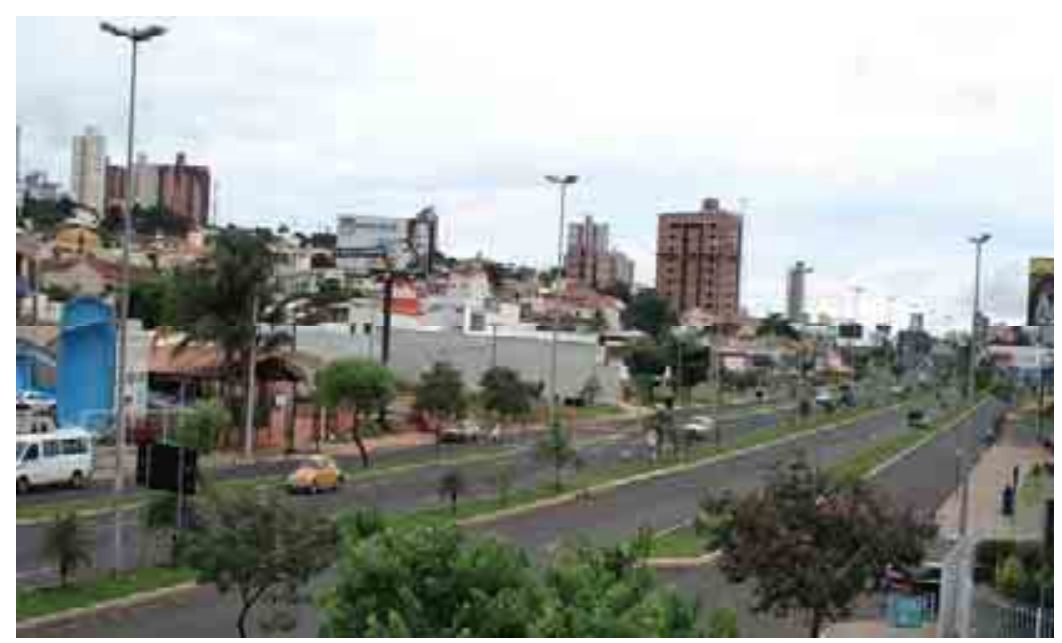

Figura 2 - Av. Rondon Pacheco. Via de trânsito rápido que absorve volume intenso de veículos, Uberlândia, 2006 Fonte: Foto da autora, 2006 
A identificação dos logradouros das vias ou segmentos críticos, resultantes das médias realizadas para as de maior número de ocorrências de acidentes de trânsito em ordem decrescente, pode ser conferida no quadro 49.

3.4 .2 - Identificação das vias ou segmentos críticos, considerando os resultados das médias das vinte vias de números mais altos de UPS dos acidentes de trânsito

As vias ou segmentos críticos do ano de 2000, considerando os números mais altos de UPS dos acidentes de trânsito, são aquelas até a sexta posição do quadro 34 , pois apresentam números acima de 216 , cujo limite foi dado pela média aritmética das vias selecionadas.

As vias ou segmentos críticos do ano de 2001, considerando os números mais altos de UPS dos acidentes de trânsito, são aquelas até a oitava posição do quadro 35 , pois apresentam números acima de 92, cujo limite foi dado pela média aritmética das vias selecionadas.

As vias ou segmentos críticos do ano de 2002, considerando os números mais altos de UPS dos acidentes de trânsito, são aquelas até a sétima posição do quadro 36, pois apresentam números acima de 318, cujo limite dado foi pela média aritmética das vias selecionadas.

As vias ou segmentos críticos do ano de 2003, considerando os números mais altos de UPS dos acidentes de trânsito, são aquelas até a sexta posição do quadro 37 , pois apresentam números acima de 330 , cujo limite foi dado pela média aritmética das vias selecionadas.

As vias ou segmentos críticos do ano de 2004, considerando os números mais altos de UPS dos acidentes de trânsito, são aquelas até a quinta posição do 
quadro 38 , pois apresentam números acima de 50 , cujo limite foi dado foi pela média aritmética das vias selecionadas.

A identificação dos logradouros das vias ou segmentos críticos, resultantes das médias realizadas para os números mais altos de UPS dos acidentes de trânsito em ordem decrescente, pode ser conferida no quadro 49.

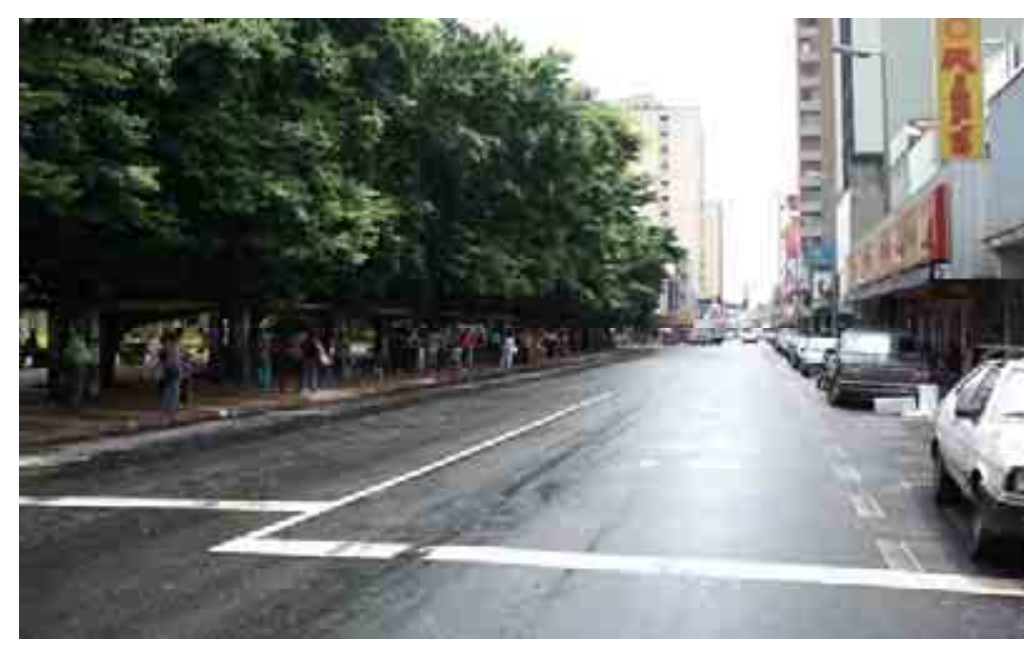

Figura 3 - Vista da Av. Afonso Pena, trecho da área central, Uberlândia, 2006

Fonte: Foto da autora, 2006 
Quadro 49 - Identificação das vias ou segmentos críticos por ano

\begin{tabular}{|c|c|c|c|c|c|c|}
\hline & $\begin{array}{l}\mathrm{N}^{\circ} . \\
\text { Ord. }\end{array}$ & 2000 & 2001 & 2002 & 2003 & 2004 \\
\hline \multirow{7}{*}{$\begin{array}{c}\mathrm{N}^{\circ} . \\
\text { Acidentes }\end{array}$} & $1^{\circ}$ & $\begin{array}{c}\text { Av.João Naves } \\
\text { de Ávila }\end{array}$ & $\begin{array}{c}\text { Av. Getúlio } \\
\text { Vargas }\end{array}$ & $\begin{array}{c}\text { Av João Naves } \\
\text { de Ávila }\end{array}$ & $\begin{array}{l}\text { Av João } \\
\text { Naves de } \\
\text { Ávila } \\
\end{array}$ & $\begin{array}{l}\text { Av.Rondon } \\
\text { Pacheco }\end{array}$ \\
\hline & $2^{\circ}$ & $\begin{array}{l}\text { Av.Rondon } \\
\text { Pacheco }\end{array}$ & $\begin{array}{c}\text { Av. Antônio } \\
\text { Thomaz Ferreira } \\
\text { de Rezende }\end{array}$ & $\begin{array}{l}\text { Av Floriano } \\
\text { Peixoto }\end{array}$ & $\begin{array}{l}\text { Av Rondon } \\
\text { Pacheco }\end{array}$ & $\begin{array}{c}\text { Av.João } \\
\text { Naves de } \\
\text { Ávila }\end{array}$ \\
\hline & $3^{\circ}$. & $\begin{array}{l}\text { Av.Afonso } \\
\text { Pena } \\
\end{array}$ & $\begin{array}{l}\text { Av. Engenheiro } \\
\text { Diniz }\end{array}$ & $\begin{array}{c}\text { Av Rondon } \\
\text { Pacheco }\end{array}$ & $\begin{array}{c}\text { Av Floriano } \\
\text { Peixoto }\end{array}$ & $\begin{array}{l}\text { BR-365/ BR- } \\
050 / \text { BR-452 }\end{array}$ \\
\hline & $4^{\circ}$ & $\begin{array}{c}\text { Av.Floriano } \\
\text { Peixoto }\end{array}$ & $\begin{array}{l}\text { Av. Fernando } \\
\text { Vilela }\end{array}$ & Av Afonso Pena & $\begin{array}{c}\text { Av Afonso } \\
\text { Pena }\end{array}$ & $\begin{array}{c}\text { Av. Getulio } \\
\text { Vargas }\end{array}$ \\
\hline & $5^{\circ}$. & $\begin{array}{l}\text { Av.Getúlio } \\
\text { Vargas }\end{array}$ & $\begin{array}{l}\text { Av. Rondon } \\
\text { Pacheco } \\
\end{array}$ & $\begin{array}{l}\text { Av João } \\
\text { Pinheiro }\end{array}$ & $\begin{array}{l}\text { Av João } \\
\text { Pinheiro }\end{array}$ & $\begin{array}{l}\text { Av. Anselmo } \\
\text { A. Santos }\end{array}$ \\
\hline & $6^{\circ}$. & $\begin{array}{l}\text { Av.Cesário } \\
\text { Alvim }\end{array}$ & $\begin{array}{c}\text { Av. Vasconcelos } \\
\text { Costa }\end{array}$ & $\begin{array}{l}\text { Av. Cesário } \\
\text { Alvim }\end{array}$ & - & $\begin{array}{c}\text { Av. } \\
\text { Nicomedes } \\
\text { A. Santos }\end{array}$ \\
\hline & $7^{\circ}$ & $\begin{array}{l}\text { Av.João } \\
\text { Pinheiro }\end{array}$ & $\begin{array}{l}\text { Av. João } \\
\text { Pinheiro }\end{array}$ & $\begin{array}{l}\text { Av. Getúlio } \\
\text { Vargas }\end{array}$ & - & - \\
\hline \multirow{7}{*}{$\mathrm{N}^{\circ}$. UPS } & $1^{\circ}$ & $\begin{array}{c}\text { Av.João Naves } \\
\text { de Ávila }\end{array}$ & $\begin{array}{l}\text { Av Getúlio } \\
\text { Vargas }\end{array}$ & $\begin{array}{c}\text { Av João Naves } \\
\text { de Ávila }\end{array}$ & $\begin{array}{c}\text { Av João } \\
\text { Naves de } \\
\text { Ávila } \\
\end{array}$ & $\begin{array}{l}\text { Av.Rondon } \\
\text { Pacheco }\end{array}$ \\
\hline & $2^{\circ}$. & $\begin{array}{c}\text { Av.Rondon } \\
\text { Pacheco } \\
\end{array}$ & $\begin{array}{c}\text { Av Engenheiro } \\
\text { Diniz } \\
\end{array}$ & $\begin{array}{c}\text { Av Floriano } \\
\text { Peixoto }\end{array}$ & $\begin{array}{c}\text { Av Rondon } \\
\text { Pacheco } \\
\end{array}$ & $\begin{array}{c}\text { Av.João } \\
\text { Naves de } \\
\text { Ávila } \\
\end{array}$ \\
\hline & $3^{\circ}$. & $\begin{array}{l}\text { Av.Afonso } \\
\text { Pena }\end{array}$ & $\begin{array}{l}\text { Av Fernando } \\
\text { Vilela }\end{array}$ & $\begin{array}{l}\text { Av Rondon } \\
\text { Pacheco }\end{array}$ & $\begin{array}{l}\text { Av Floriano } \\
\text { Peixoto }\end{array}$ & $\begin{array}{l}\text { BR-365/ BR- } \\
\text { 452/ BR-050 }\end{array}$ \\
\hline & $4^{\circ}$. & $\begin{array}{l}\text { Av.Floriano } \\
\text { Peixoto }\end{array}$ & $\begin{array}{l}\text { Av Antonio } \\
\text { Thomaz F. de } \\
\text { Rezende }\end{array}$ & Av Afonso Pena & $\begin{array}{l}\text { Av Afonso } \\
\text { Pena }\end{array}$ & $\begin{array}{c}\text { Av. Anselmo } \\
\text { Alves } \\
\text { Santos }\end{array}$ \\
\hline & $5^{\circ}$ & $\begin{array}{l}\text { Av.Cesário } \\
\text { Alvim }\end{array}$ & $\begin{array}{c}\text { Av Aspirante } \\
\text { Mega }\end{array}$ & $\begin{array}{l}\text { Av João } \\
\text { Pinheiro } \\
\end{array}$ & $\begin{array}{l}\text { Av João } \\
\text { Pinheiro }\end{array}$ & $\begin{array}{l}\text { Av. Getúlio } \\
\text { Vargas }\end{array}$ \\
\hline & $6^{\circ}$ & $\begin{array}{l}\text { Av.Getúlio } \\
\text { Vargas }\end{array}$ & $\begin{array}{c}\text { Av Vasconcelos } \\
\text { Costa }\end{array}$ & $\begin{array}{l}\text { Av Getúlio } \\
\text { Vargas }\end{array}$ & $\begin{array}{l}\text { Av Getúlio } \\
\text { Vargas }\end{array}$ & - \\
\hline & $7^{\circ}$ & - & - & $\begin{array}{l}\text { Av Cesário } \\
\text { Alvim }\end{array}$ & - & - \\
\hline
\end{tabular}

Org: BERNARDINO, A.R., 2007

As vias ou segmentos que resultaram nas consideradas situações críticas com relação ao maior número de acidentes e números mais altos de UPS, que aparecem em todos os anos analisados, são as Av. João Naves de Ávila, Av. Rondon Pacheco, Av. Afonso Pena e Av. Floriano Peixoto. 
A exceção do resultado das vias, apresentadas para o ano de 2001, foi necessária, uma vez que as principais (Av. João Naves de Ávila, Av. Rondon Pacheco, Av. Afonso Pena e Av. Floriano Peixoto) não apareceram como situação crítica daquele ano. Dessa forma, acrescenta-se, de acordo às justificativas apresentadas no capítulo 2, que o $17^{\circ}$. Batalhão da Polícia Militar que ficou sem coletar e tabular os dados é o que está localizado na região de abrangência dessas vias, e assim, o motivo para elas não serem citadas.

Assim, as vias críticas, também, importantes, apareceram para o ano de 2001 foram; as Av.Getúlio Vargas, Av. Antônio Thomaz Ferreira de Rezende, Av. Engenheiro Diniz, Av. Fernando Vilela, Av. Vasconcelos Costa, Av. João Pinheiro e Av. Aspirante Mega, considerando as duas vertentes de análise, números absolutos e número de UPS para os acidentes de trânsito (cf. quadro 49).

Salienta-se que essas vias também absorvem fluxos intensos de veículos pelo acesso a setores comerciais importantes da cidade, como o bairro Martins, e ainda adentram outros importantes, como o Planalto e o setor de indústrias, além de oferecer fluxo rápido quando utilizadas.

3.4.3 - Identificação dos trechos críticos, considerando os resultados das médias dos vinte trechos de maior número de acidentes de trânsito

Os trechos críticos do ano de 2000, considerando o número maior de ocorrências de acidentes de trânsito, são aqueles até a sexta classificação do quadro 24 , pois apresentam números de acidentes acima de 7 , cujo limite foi dado pela média aritmética dos trechos selecionados.

Os trechos críticos do ano de 2001, considerando o número maior de ocorrências de acidentes de trânsito, são aqueles até a décima posição do quadro 
25, pois apresentam números de acidentes acima de 2, cujo limite foi dado pela média aritmética dos trechos selecionados.

Os trechos críticos do ano de 2002, considerando o número maior de ocorrências de acidentes de trânsito, são aqueles até a oitava posição do quadro 26, pois apresentam números de acidentes acima de 5 , cujo limite foi dado pela média aritmética dos trechos selecionados.

Os trechos críticos do ano de 2003, considerando o número maior de ocorrências de acidentes de trânsito, são aqueles até a oitava posição do quadro 27, pois apresentam números de acidentes acima de 9 , cujo limite foi dado pela média aritmética dos trechos selecionados.

Os trechos críticos do ano de 2004, considerando o número maior de ocorrências de acidentes de trânsito, são aqueles até a décima posição do quadro 28, pois apresentam números de acidentes acima de 7 , cujo limite foi dado pela média aritmética dos trechos selecionados.

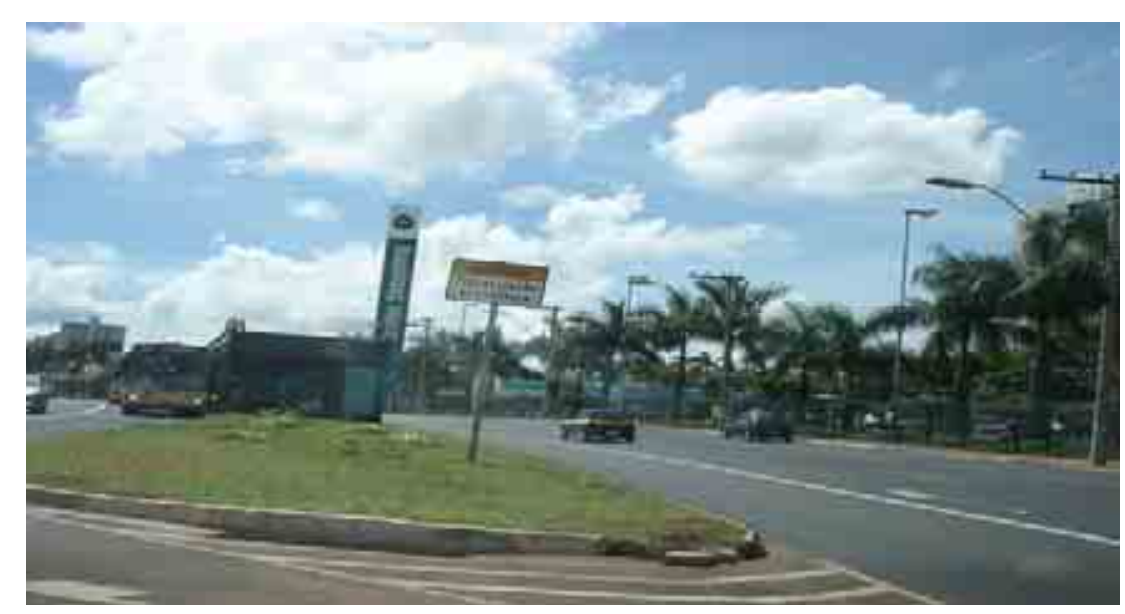

Figura 4 - Vista parcial do trecho da Av. João Naves de Ávila entre Av. Ubiratan Honório de Castro e R. Luiza de Jesus, Uberlândia, 2006

Fonte: foto da autora, 2006

A identificação dos logradouros dos trechos críticos, resultantes das médias realizadas para os números maiores de ocorrências de acidentes de trânsito, em ordem decrescente, pode ser conferida no quadro 50 . 
3.4.4 - Identificação dos trechos críticos considerando os resultados das médias dos vinte trechos de números mais altos de UPS dos acidentes de trânsito

Os trechos críticos do ano de 2000 , considerando os números mais altos de UPS dos acidentes de trânsito, são aqueles até a sexta posição do quadro 39, pois apresentam números acima de 13 , cujo limite foi dado pela média aritmética dos trechos selecionados.

Os trechos críticos do ano de 2001, considerando os números mais altos de UPS dos acidentes de trânsito, são aqueles até a oitava posição do quadro 40 , pois apresentam números acima de 9 , cujo limite foi dado pela média aritmética dos trechos selecionados.

Os trechos críticos do ano de 2002, considerando os números mais altos de UPS dos acidentes de trânsito, são aqueles até a quinta posição do quadro 41 , pois apresentam números acima de 15 , cujo limite foi dado pela média aritmética dos trechos selecionados.

Os trechos críticos do ano de 2003, considerando os números mais altos de UPS dos acidentes de trânsito, são aqueles até a sétima posição do quadro 42 , pois apresentam números acima de 23 , cujo limite foi dado pela média aritmética dos trechos selecionados.

Os trechos críticos do ano de 2004, considerando os números mais altos de UPS dos acidentes de trânsito são aqueles até a quinta posição do quadro 43 , pois, apresentam números acima de 15 , cujo limite foi dado foi pela média aritmética dos trechos selecionados.

O quadro 50 identifica, a partir de seus logradouros, os principais trechos críticos resultantes das médias realizadas para os números mais altos de UPS dos anos analisados, em ordem decrescente. 


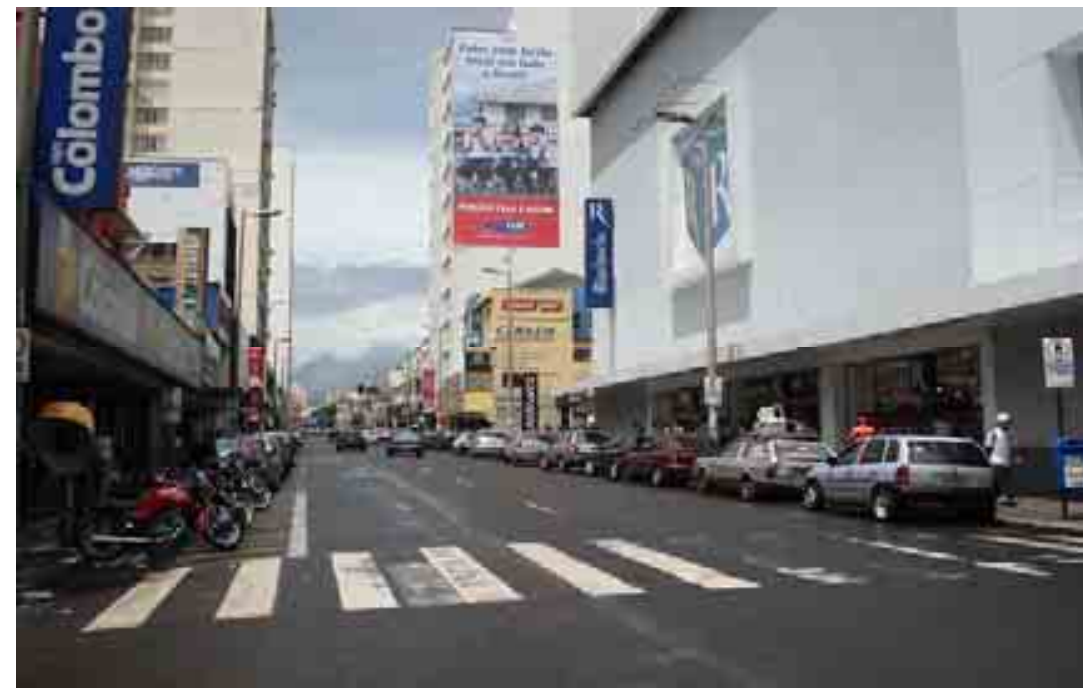

Figura 5 - Vista do trecho compreendido pela Av. Afonso Pena e suas interseções, R. Duque de Caxias e R. Machado de Assis, Uberlândia, 2006

Fonte: Foto da autora, 2006

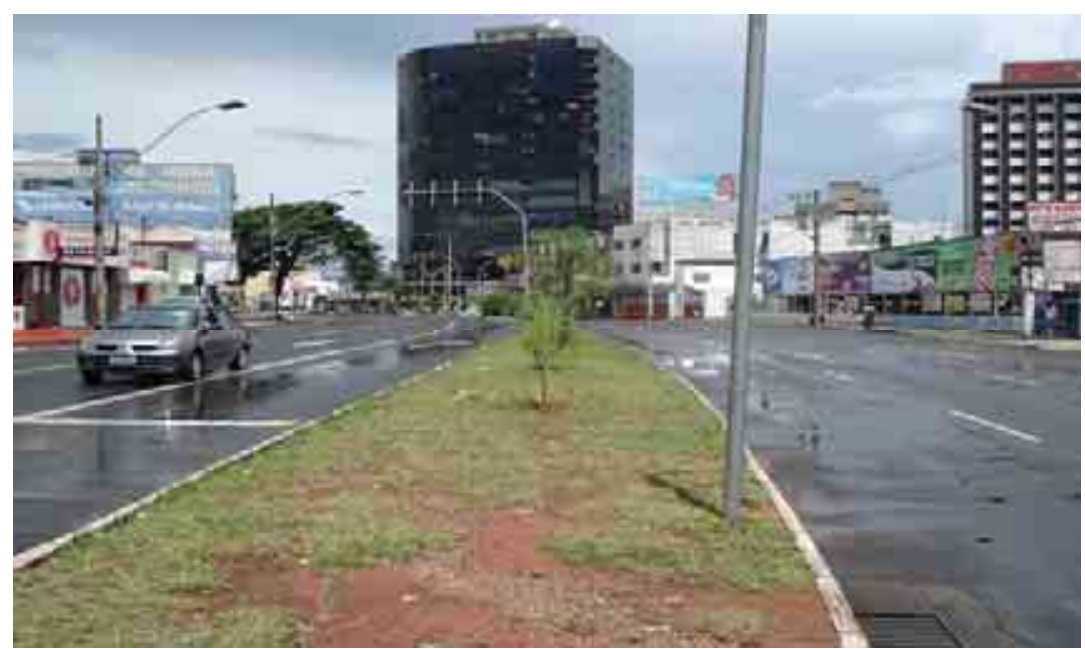

Figura 6 - Vista do trecho compreendido pela Av. João Naves de Ávila e suas interseções, Av. Floriano Peixoto e Av. Cesário Alvim, Uberlândia, 2006

Fonte: Foto da autora, 2006 
Quadro 50 - Identificação dos trechos críticos por ano

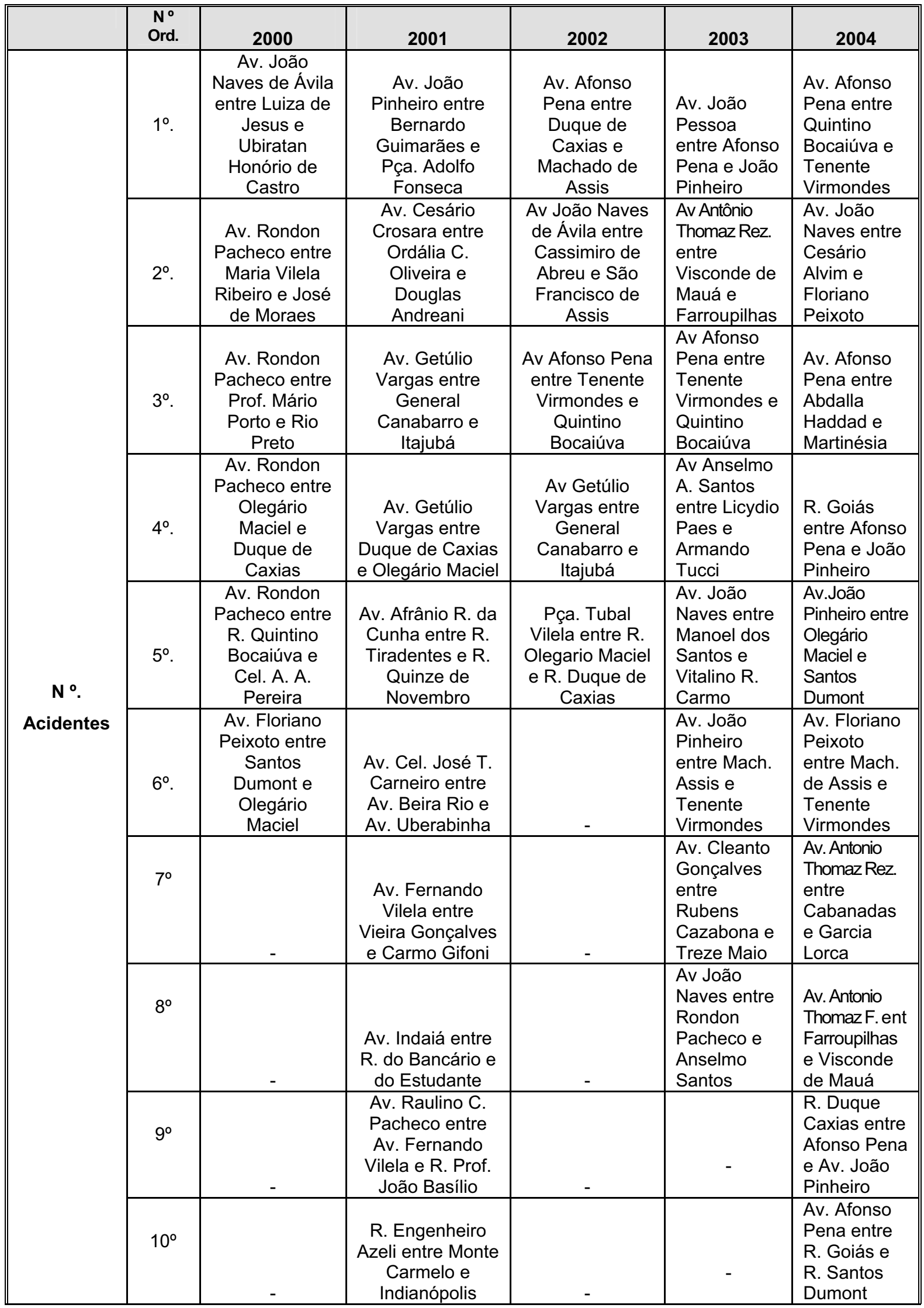


Cont. Quadro 50

\begin{tabular}{|c|c|c|c|c|c|c|}
\hline & $\begin{array}{l}\mathbf{N}^{\circ} . \\
\text { Ord. }\end{array}$ & 2000 & 2001 & 2002 & 2003 & 2004 \\
\hline \multirow{8}{*}{$\mathrm{N}^{\circ}$. UPS } & $1^{\circ}$. & $\begin{array}{l}\text { Av.João Naves } \\
\text { de Ávila entre } \\
\text { Luiza de Jesus } \\
\text { e Ubiratan } \\
\text { Honório de } \\
\text { Castro }\end{array}$ & $\begin{array}{l}\text { Av Taylor Silva } \\
\text { entre Garibalde } \\
\text { Alves Vieira e R. } \\
\text { do Carnaval }\end{array}$ & $\begin{array}{l}\text { Av João Naves } \\
\text { de Ávila entre } \\
\text { Cassimiro de } \\
\text { Abreu e São } \\
\text { Francisco Assis }\end{array}$ & $\begin{array}{l}\text { Av João } \\
\text { Pessoa } \\
\text { entre Afonso } \\
\text { Pena e João } \\
\text { Pinheiro }\end{array}$ & $\begin{array}{l}\text { Av.João } \\
\text { Naves de } \\
\text { Ávila entre } \\
\text { Cesário } \\
\text { Alvim e } \\
\text { Floriano } \\
\text { Peixoto }\end{array}$ \\
\hline & $2^{\circ}$ & $\begin{array}{l}\text { Av. Rondon } \\
\text { Pacheco entre } \\
\text { Olegário } \\
\text { Maciel e } \\
\text { Duque de } \\
\text { Caxias }\end{array}$ & $\begin{array}{l}\text { Av Uirapuru } \\
\text { entre José de } \\
\text { Oliveira Pinto e } \\
\text { R. dos Pardais }\end{array}$ & $\begin{array}{l}\text { Av Silvio } \\
\text { Rugani entre } \\
\text { Tomé de Souza } \\
\text { e Nilo Peçanha }\end{array}$ & $\begin{array}{l}\text { Av.Antonio } \\
\text { ThomazF. } \\
\text { Rezende entre } \\
\text { Visconde de } \\
\text { Mauá e } \\
\text { Farroupilhas }\end{array}$ & $\begin{array}{l}\text { Av.Afonso } \\
\text { Pena entre } \\
\text { Quintino } \\
\text { Bocaiúva e } \\
\text { Tenente } \\
\text { Virmondes }\end{array}$ \\
\hline & $3^{\circ}$ & $\begin{array}{l}\text { Av. Rondon } \\
\text { Pacheco entre } \\
\text { Quintino } \\
\text { Bocaiúva e } \\
\text { Cel. Antônio } \\
\text { Alves Pereira }\end{array}$ & $\begin{array}{l}\text { Av Araguari entre } \\
\text { Pça Adalberto R. } \\
\text { da Cunha e Paes } \\
\text { Leme }\end{array}$ & $\begin{array}{l}\text { Av Getúlio } \\
\text { Vargas entre } \\
\text { General } \\
\text { Canabarro e } \\
\text { Itajubá }\end{array}$ & $\begin{array}{l}\text { Av Anselmo } \\
\text { A. dos } \\
\text { Santos entre } \\
\text { Licydio Paes } \\
\text { e Armando } \\
\text { Tucci }\end{array}$ & $\begin{array}{l}\text { Av.João } \\
\text { Pessoa } \\
\text { entre Afonso } \\
\text { Pena e João } \\
\text { Pinheiro }\end{array}$ \\
\hline & $4^{\circ}$. & $\begin{array}{l}\text { Av.Rondon } \\
\text { Pacheco entre } \\
\text { Maria Vilela } \\
\text { Ribeiro e José } \\
\text { de Morais } \\
\end{array}$ & $\begin{array}{l}\text { Av Cel José T. } \\
\text { Carneiro entre } \\
\text { Luiz Ferreira } \\
\text { Lima e Beira Rio }\end{array}$ & $\begin{array}{l}\text { Av Angelino } \\
\text { Favato entre } \\
\text { Ala. Antônio } \\
\text { Carlos V. } \\
\text { Cunha e Ala. } \\
\text { Antônio Ovídio }\end{array}$ & $\begin{array}{l}\text { Av Afonso } \\
\text { Pena entre } \\
\text { Tenente } \\
\text { Virmondes e } \\
\text { Quintino } \\
\text { Bocaiúva } \\
\end{array}$ & $\begin{array}{l}\text { Av.Afonso } \\
\text { Pena entre } \\
\text { Abdalla } \\
\text { Haddad e } \\
\text { Martinésia } \\
\end{array}$ \\
\hline & $5^{\circ}$. & $\begin{array}{l}\text { Av.Floriano } \\
\text { Peixoto entre } \\
\text { Santos } \\
\text { Dumont e } \\
\text { Olegário } \\
\text { Maciel }\end{array}$ & $\begin{array}{l}\text { Av Constelação } \\
\text { entre Paulo } \\
\text { Roberto C. } \\
\text { Santos e R. } \\
\text { Bauru }\end{array}$ & $\begin{array}{l}\text { Av Cleanto } \\
\text { V.Gonçalves } \\
\text { entre Rubens } \\
\text { Cazabona e } \\
\text { Treze de Maio } \\
\end{array}$ & $\begin{array}{l}\text { Av Cleanto } \\
\text { V.Gonçalves } \\
\text { entre } \\
\text { Rubens } \\
\text { Cazabona e } \\
\text { Treze de } \\
\text { Maio }\end{array}$ & $\begin{array}{l}\text { Av.Getúlio } \\
\text { Vargas entre } \\
\text { General } \\
\text { Canabarro e } \\
\text { Itajubá }\end{array}$ \\
\hline & $6^{\circ}$. & $\begin{array}{l}\text { Av.Antonio } \\
\text { Thomaz F. } \\
\text { Rezende entre } \\
\text { Farroupilhas e } \\
\text { Sabinadas }\end{array}$ & $\begin{array}{l}\text { Av João Pessoa } \\
\text { entre Monte } \\
\text { Carmelo e } \\
\text { Indianópolis }\end{array}$ & - & $\begin{array}{l}\text { Av João } \\
\text { Naves entre } \\
\text { Floriano } \\
\text { Peixoto e } \\
\text { Cesário } \\
\text { Alvim }\end{array}$ & - \\
\hline & $7^{\circ}$ & - & $\begin{array}{l}\text { Av Cesário } \\
\text { Crosara entre } \\
\text { Ordália C. } \\
\text { Oliveira e } \\
\text { Douglas } \\
\text { Andreani }\end{array}$ & - & $\begin{array}{l}\text { Av João } \\
\text { Naves de } \\
\text { Ávila entre } \\
\text { Rio Branco } \\
\text { e Rondon } \\
\text { Pacheco } \\
\end{array}$ & - \\
\hline & $8^{\circ}$ & - & $\begin{array}{l}\text { Av Getúlio } \\
\text { Vargas entre } \\
\text { Duque de Caxias } \\
\text { e Olegário Maciel }\end{array}$ & - & - & - \\
\hline
\end{tabular}

Org: BERNARDINO, A.R., 2007

Salienta-se que os trechos críticos se distribuem mais na malha viária. São porções limitadas das vias que abrangem as Av. Floriano Peixoto e Av. Afonso Pena, trechos do entorno do "shopping center", hipermercado, prédios da Câmara Municipal e blocos de entrada à Prefeitura de Uberlândia, de que a Av. João 
Naves de Ávila é a principal via de acesso tendo como interseções principais as R. Luiza de Jesus e Av. Ubiratan Honório de Castro. Outros trechos que interceptam a Av. João Naves de Ávila como a R. Cassimiro de Abreu e R. São Francisco de Assis também são identificados.

3.4.5 - Identificação dos cruzamentos ou pontos críticos considerando os resultados das médias dos vinte trechos de maior número de acidentes

Os cruzamentos ou pontos críticos do ano de 2000, considerando o número maior de ocorrências de acidentes de trânsito, são aqueles até a terceira posição do quadro 29, pois apresentam números de acidentes acima de 18 , cujo limite foi dado pela média aritmética dos cruzamentos selecionados.

Os cruzamentos ou pontos críticos do ano de 2001, considerando o número maior de ocorrências de acidentes de trânsito, são aqueles até a nona posição do quadro 30 , pois apresentam números de acidentes acima de 7 , cujo limite foi dado pela média aritmética dos cruzamentos selecionados.

Os cruzamentos ou pontos críticos do ano de 2002, considerando o número maior de ocorrências de acidentes de trânsito, são aqueles até a sexta posição do quadro 31, pois apresentam números de acidentes acima de 18, cujo limite foi dado pela média aritmética dos cruzamentos selecionados.

Os cruzamentos ou pontos críticos do ano de 2003, considerando o número maior de ocorrências de acidentes de trânsito, são aqueles até a sétima posição do quadro 32 , pois apresentam números de acidentes acima de 21 , cujo limite foi dado pela média aritmética dos cruzamentos selecionados.

Os cruzamentos ou pontos críticos do ano de 2004, considerando o número maior de ocorrências de acidentes de trânsito, são aqueles até a terceira 
posição do quadro 33 , pois apresentam números de acidentes acima de 27 , cujo limite foi dado pela média aritmética dos cruzamentos selecionados.

O quadro 51 identifica, a partir de seus logradouros, em ordem decrescente, os principais cruzamentos ou pontos críticos resultantes das médias realizadas para os de maior número de acidentes de trânsito dos anos analisados.

3.4.6 - Identificação dos cruzamentos ou pontos críticos considerando os resultados das médias dos vinte trechos de números mais altos de UPS dos acidentes de trânsito

Os cruzamentos ou pontos críticos do ano de 2000, considerando os números mais altos de UPS dos acidentes de trânsito, são aqueles até a quarta posição do quadro 44, pois apresentam números acima de 33 , cujo limite foi dado pela média aritmética dos cruzamentos selecionados.

Os cruzamentos ou pontos críticos do ano de 2001, considerando os números mais altos de UPS dos acidentes de trânsito, são aqueles até a sétima posição do quadro 45 , pois apresentam números acima de 20 , cujo limite foi dado pela média aritmética dos cruzamentos selecionados.

Os cruzamentos ou pontos críticos do ano de 2002, considerando os números mais altos de UPS dos acidentes de trânsito, são aqueles até a sexta posição do quadro 46, pois apresentam números acima de 39 , cujo limite dado foi pela média aritmética dos cruzamentos selecionados.

Os cruzamentos ou pontos críticos do ano de 2003, considerando os números mais altos de UPS dos acidentes de trânsito, são aqueles até a quarta posição do quadro 47 , pois apresentam números acima de 42 , cujo limite foi dado foi pela média aritmética dos cruzamentos selecionados. 
Os cruzamentos ou pontos críticos do ano de 2004, considerando os números mais altos de UPS dos acidentes de trânsito, são aqueles até a quarta posição do quadro 48 , pois apresentam números acima de 44 , cujo limite foi dado foi pela média aritmética dos cruzamentos selecionados.

A identificação dos logradouros dos cruzamentos ou pontos críticos, resultantes das médias realizadas para os números mais altos de UPS dos acidentes de trânsito, em ordem decrescente, pode ser conferida no quadro 51.

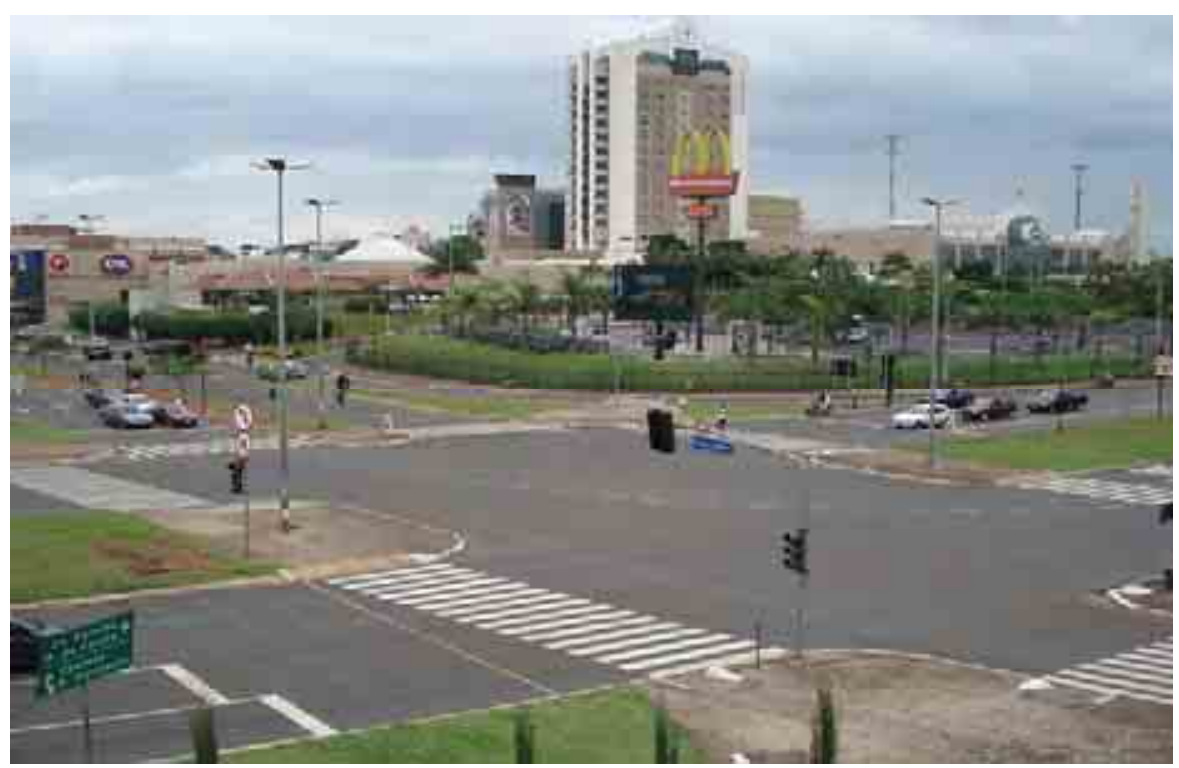

Figura 7 - Vista do cruzamento da Av. João Naves de Ávila com a Av. Rondon Pacheco, Uberlândia, 2007.

Fonte: Foto da autora, 2007 
Quadro 51 - Identificação dos cruzamentos ou pontos críticos por ano

\begin{tabular}{|c|c|c|c|c|c|c|}
\hline & $\begin{array}{l}\mathrm{N}^{\circ} . \\
\text { Ord }\end{array}$ & 2000 & 2001 & 2002 & 2003 & 2004 \\
\hline \multirow{9}{*}{$\begin{array}{c}\mathrm{N}^{\circ} \text {. } \\
\text { Acidentes }\end{array}$} & $1^{\circ}$ & $\begin{array}{l}\text { João Naves de } \\
\text { Ávila/ Rondon } \\
\text { Pacheco }\end{array}$ & $\begin{array}{l}\text { Antonio Thomaz } \\
\text { F.de Rezende/ } \\
\text { Com. } \\
\text { Alexandrino } \\
\text { Garcia }\end{array}$ & $\begin{array}{l}\text { João Naves de } \\
\text { Ávila/ Rondon } \\
\text { Pacheco }\end{array}$ & $\begin{array}{l}\text { João Naves } \\
\text { de Ávila/ } \\
\text { Rondon } \\
\text { Pacheco } \\
\end{array}$ & $\begin{array}{l}\text { João Naves } \\
\text { de Ávila/ } \\
\text { Rondon } \\
\text { Pacheco } \\
\end{array}$ \\
\hline & $2^{\circ}$ & $\begin{array}{l}\text { Nicomedes } \\
\text { Alves dos } \\
\text { Santos/ } \\
\text { Rondon } \\
\text { Pacheco } \\
\end{array}$ & $\begin{array}{l}\text { Engenheiro } \\
\text { Diniz/ } \\
\text { Engenheiro Azeli }\end{array}$ & $\begin{array}{l}\text { Floriano } \\
\text { Peixoto/João } \\
\text { Naves de Ávila }\end{array}$ & $\begin{array}{l}\text { Antônio } \\
\text { Thomaz } \\
\text { F.Rezende/ } \\
\text { Com. } \\
\text { Alexandrino } \\
\text { Garcia } \\
\end{array}$ & $\begin{array}{l}\text { Nicomedes } \\
\text { Alves dos } \\
\text { Santos/ } \\
\text { Rondon } \\
\text { Pacheco } \\
\end{array}$ \\
\hline & $3^{\circ}$ & $\begin{array}{l}\text { Cesário } \\
\text { Alvim/João } \\
\text { Naves de Ávila }\end{array}$ & $\begin{array}{l}\text { Brigadeiro } \\
\text { Sampaio/ Ipê }\end{array}$ & $\begin{array}{l}\text { Antônio } \\
\text { Thomaz F. de } \\
\text { Rezende/ Com. } \\
\text { Alexandrino } \\
\text { Garcia } \\
\end{array}$ & $\begin{array}{l}\text { Nicomedes } \\
\text { Alves dos } \\
\text { Santos/ } \\
\text { Rondon } \\
\text { Pacheco } \\
\end{array}$ & $\begin{array}{l}\text { Floriano } \\
\text { Peixoto/ } \\
\text { João Naves } \\
\text { de Ávila } \\
\end{array}$ \\
\hline & $4^{\circ}$ & - & $\begin{array}{l}\text { Engenheiro } \\
\text { Diniz/ Raulino } \\
\text { Cotta Pacheco } \\
\end{array}$ & $\begin{array}{l}\text { Engenheiro } \\
\text { Dinizl } \\
\text { Engenheiro } \\
\text { Azeli }\end{array}$ & $\begin{array}{l}\text { Floriano } \\
\text { Peixoto/ } \\
\text { João Naves } \\
\text { de Avila } \\
\end{array}$ & - \\
\hline & $5^{\circ}$ & - & $\begin{array}{l}\text { Fernando Vilela/ } \\
\text { Marcos de } \\
\text { Freitas Costa }\end{array}$ & $\begin{array}{l}\text { Nicomedes } \\
\text { Alves dos } \\
\text { Santos/Rondon } \\
\text { Pacheco }\end{array}$ & $\begin{array}{l}\text { Aspirante } \\
\text { Mega/ } \\
\text { Getúlio } \\
\text { Vargas } \\
\end{array}$ & - \\
\hline & $6^{\circ}$. & - & $\begin{array}{l}\text { Profa. Minervina } \\
\text { C. Oliveira/ } \\
\text { Raulino Cotta } \\
\text { Pacheco }\end{array}$ & - & $\begin{array}{l}\text { Rondon } \\
\text { Pacheco/ } \\
\text { General } \\
\text { Osório } \\
\end{array}$ & - \\
\hline & $7^{\circ}$ & - & $\begin{array}{l}\text { Fernando Vilela/ } \\
\text { João Pessoa }\end{array}$ & - & $\begin{array}{l}\text { João Naves } \\
\text { de Ávila/ } \\
\text { Segismundo } \\
\text { Pereira }\end{array}$ & - \\
\hline & $8^{\circ}$ & - & $\begin{array}{l}\text { João Naves de } \\
\text { Ávila/ Rondon } \\
\text { Pacheco }\end{array}$ & - & - & - \\
\hline & $9^{\circ}$. & - & $\begin{array}{l}\text { Paes Leme/ } \\
\text { Tapuirama }\end{array}$ & - & - & - \\
\hline
\end{tabular}


Cont. Quadro 51

\begin{tabular}{|c|c|c|c|c|c|c|}
\hline & $\begin{array}{l}\mathrm{N}^{\circ} \text {. } \\
\text { Ord }\end{array}$ & 2000 & 2001 & 2002 & 2003 & 2004 \\
\hline \multirow{7}{*}{$\mathrm{N}^{\circ}$. UPS } & $1^{\circ}$. & $\begin{array}{l}\text { João Naves de } \\
\text { Ávila/ Rondon } \\
\text { Pacheco }\end{array}$ & $\begin{array}{l}\text { Antonio Thomaz } \\
\text { F. de Rezende/ } \\
\text { Com. } \\
\text { Alexandrino } \\
\text { Garcia }\end{array}$ & $\begin{array}{l}\text { João Naves de } \\
\text { Ávila/ Rondon } \\
\text { Pacheco }\end{array}$ & $\begin{array}{l}\text { João Naves } \\
\text { de Ávila/ } \\
\text { Rondon } \\
\text { Pacheco } \\
\end{array}$ & $\begin{array}{l}\text { João Naves } \\
\text { de Ávila/ } \\
\text { Rondon } \\
\text { Pacheco }\end{array}$ \\
\hline & $2^{\circ}$ & $\begin{array}{l}\text { Nicomedes } \\
\text { Alves dos } \\
\text { Santos/ } \\
\text { Rondon } \\
\text { Pacheco } \\
\end{array}$ & $\begin{array}{l}\text { Engenheiro } \\
\text { Diniz/ } \\
\text { Engenheiro Azeli }\end{array}$ & $\begin{array}{l}\text { Floriano } \\
\text { Peixoto/ João } \\
\text { Naves de Ávila }\end{array}$ & $\begin{array}{l}\text { Antonio } \\
\text { Thomaz F. } \\
\text { Rezende/ } \\
\text { Com. } \\
\text { Alexandrino } \\
\text { Garcia } \\
\end{array}$ & $\begin{array}{l}\text { Nicomedes } \\
\text { Alves dos } \\
\text { Santos/ } \\
\text { Rondon } \\
\text { Pacheco } \\
\end{array}$ \\
\hline & $3^{\circ}$. & $\begin{array}{l}\text { Cesário Alvim/ } \\
\text { João Naves de } \\
\text { Ávila }\end{array}$ & $\begin{array}{l}\text { Brigadeiro } \\
\text { Sampaio/lpê }\end{array}$ & $\begin{array}{l}\text { Engenheiro } \\
\text { Diniz/ } \\
\text { Engenheiro } \\
\text { Azeli }\end{array}$ & $\begin{array}{l}\text { Aspirante } \\
\text { Mega/ } \\
\text { Getúlio } \\
\text { Vargas }\end{array}$ & $\begin{array}{l}\text { Antonio } \\
\text { Thomaz F. } \\
\text { Rezende/ } \\
\text { Com. } \\
\text { Alexandrino } \\
\text { Garcia } \\
\end{array}$ \\
\hline & $4^{\circ}$. & $\begin{array}{l}\text { Belarmino } \\
\text { Cotta } \\
\text { Pacheco/ } \\
\text { Sebastião } \\
\text { Rangel } \\
\end{array}$ & $\begin{array}{l}\text { Fernando Vilela/ } \\
\text { Marcos de } \\
\text { Freitas Costa }\end{array}$ & $\begin{array}{l}\text { Antônio } \\
\text { Thomaz F. de } \\
\text { Rezende/ Com. } \\
\text { Alexandrino } \\
\text { Garcia } \\
\end{array}$ & $\begin{array}{l}\text { João Naves } \\
\text { de Ávila/ } \\
\text { Segismundo } \\
\text { Pereira } \\
\end{array}$ & $\begin{array}{l}\text { Araguari/ } \\
\text { Padre Pio } \\
\end{array}$ \\
\hline & $5^{\circ}$. & - & $\begin{array}{l}\text { Getúlio Vargas/ } \\
\text { Marcos de } \\
\text { Freitas Costa }\end{array}$ & $\begin{array}{l}\text { Afonso Pena/ } \\
\text { Olegário Maciel }\end{array}$ & - & - \\
\hline & $6^{\circ}$. & - & $\begin{array}{l}\text { das Gameleiras/ } \\
\text { Imbaúbas }\end{array}$ & $\begin{array}{l}\text { Cesário Alvim/ } \\
\text { João Naves de } \\
\text { Ávila }\end{array}$ & - & - \\
\hline & $7^{\circ}$. & - & $\begin{array}{l}\text { Engenheiro } \\
\text { Diniz/ Raulino } \\
\text { Cotta Pacheco } \\
\end{array}$ & - & - & - \\
\hline
\end{tabular}

Org: BERNARDINO, A.R., 2007

O quadro 51 identifica os cruzamentos que foram considerados críticos por meio das médias aritméticas contemplando os pontos de maior número de acidentes e números mais altos de UPS dos acidentes de trânsito ocorridos em Uberlândia para os anos de 2000 a 2004.

Ressalta-se que o cruzamento na área urbana não é somente aquele que localiza na área mais adensada, mas também a menos adensada, possuindo qualquer tipo de uso do solo. Neste caso, exemplifica-se a Av. Antônio Thomaz Ferreira de Rezende com Av. Comendador Alexandrino Garcia, cuja localização é fora dos limites de aglomerações de pedestres e veículos, porém é reconhecida como cruzamento perigoso com ocorrência de acidentes de alta severidade. A Av. 
Antônio Thomaz Ferreira de Rezende é uma via que oferece continuidade à rodovia BR-050, sendo que, após o trevo de entrada para a cidade, é utilizada para acessar o setor de indústrias, o anel viário, além de outra rodovia vicinal que alcançam dois distritos de Uberlândia.

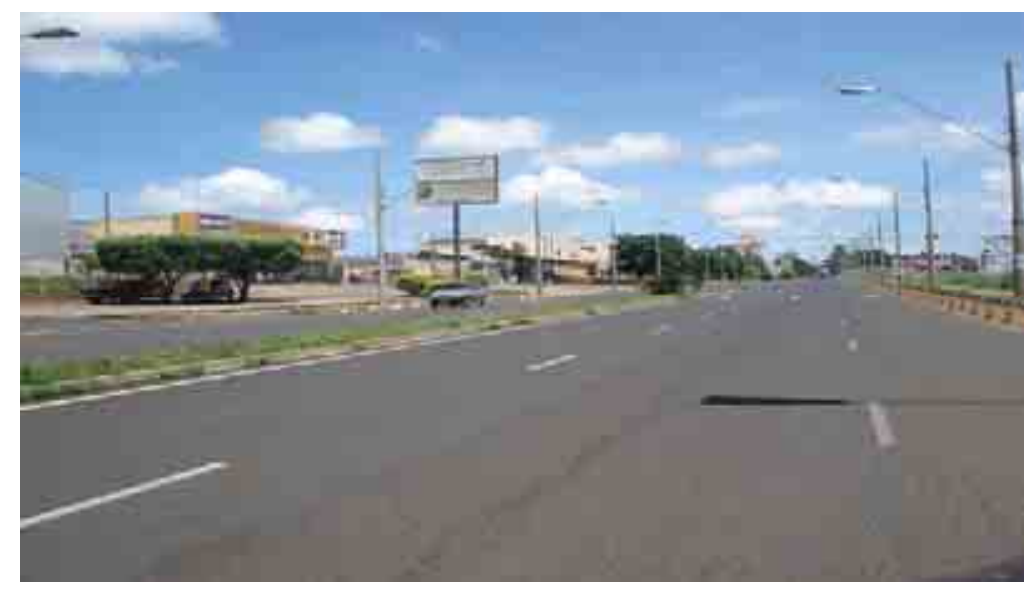

Figura 8 - Vista parcial da Av. Antônio Thomaz Ferreira de Rezende que faz importante ligação para o setor de indústrias, Uberlândia, 2007

Fonte: Foto da autora, 2007

O cruzamento viário urbano é um espaço situado entre o limite dos lotes num cruzamento de vias e que inclui o leito carroçável e as calçadas para pedestres. Este espaço pode ter as mais diversas características, pois pode ser estreito, largo, redondo, quadrado, irregular, arborizado ou não, e que, neste caso, configura-se como largo (cf. figura 6).

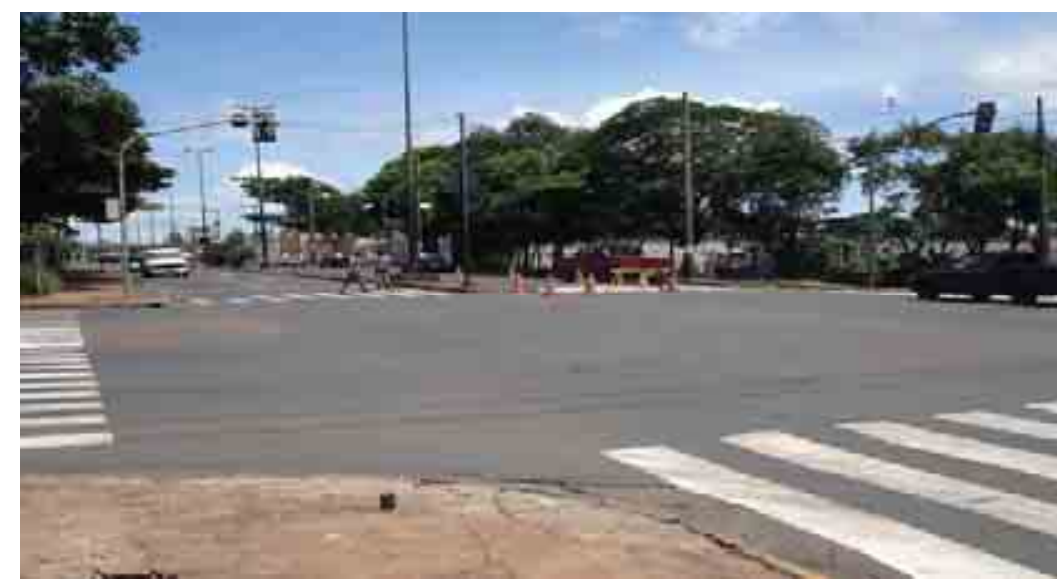

Figura 9 - Av. Antônio Thomaz Ferreira de Rezende com Av. Comendador Alexandrino Garcia. Observação da largura do cruzamento, Uberlândia, 2007

Fonte: foto da autora, 2007 
Nesse cruzamento, em abril de 2003, um acidente envolvendo uma carreta, matou uma criança de 2 anos e deixou uma outra de 5 anos gravemente ferida. $A$ mãe das meninas aguardava, na calçada da Av. Comendador Alexandrino Garcia, o semáforo indicar o sinal para ela atravessar. A carreta descia pela mesma avenida em direção do setor industrial, e o motorista fez a conversão e as rodas traseiras do caminhão atropelaram o carrinho em que estavam o bebê e a criança (cf. reportagem no anexo 3).

Menciona-se, neste momento, a contribuição das condições geométricas e de infra-estrutura do cruzamento somadas às condições do veículo e ao perfil do condutor, em diferentes pesos, e, dessa forma agrupados, que denotam a ocorrência do conflito.

De posse dos resultados relativos aos anos de 2000 a 2004 e com o intuito de unir as análises realizadas, apresentam-se as vias, os trechos e os cruzamentos críticos do ano de 2004 obtidos por meio das análises realizadas por número de acidentes e por números de UPS, a fim de espacializá-los, tendo em vista que é este, o ano analisado mais recente, identificando os segmentos no que se refere à representatividade temporária para a realidade da cidade de Uberlândia (cf. quadro 52 e mapa 36). 
Quadro 52 - Identificação das vias, dos trechos e dos cruzamentos críticos para o ano de 2004

\begin{tabular}{|c|c|c|c|c|c|}
\hline \multicolumn{2}{|c|}{ VIAS } & \multicolumn{2}{|c|}{ TRECHOS } & \multicolumn{2}{|c|}{ CRUZAMENTOS } \\
\hline $\begin{array}{c}\mathrm{N}^{\circ} . \\
\text { ACIDENTES }\end{array}$ & $\mathrm{N}^{\circ}$. UPS & $\mathrm{N}^{\circ}$. ACIDENTES & $N^{\circ}$. UPS & $\begin{array}{c}\mathrm{N}^{\circ} . \\
\text { ACIDENTES }\end{array}$ & $\mathrm{N}^{\circ}$. UPS \\
\hline $\begin{array}{l}\text { Av.Rondon } \\
\text { Pacheco }\end{array}$ & $\begin{array}{l}\text { Av.Rondon } \\
\text { Pacheco }\end{array}$ & $\begin{array}{c}\text { Av.Afonso Pena } \\
\text { entre R.Quintino } \\
\text { Bocaiúva e } \\
\text { R.Tenente } \\
\text { Virmondes }\end{array}$ & $\begin{array}{c}\text { Av João Naves } \\
\text { entre Av.Cesário } \\
\text { Alvim e } \\
\text { Av.Floriano } \\
\text { Peixoto }\end{array}$ & $\begin{array}{c}\text { Av.João Naves } \\
\text { de Ávila/ } \\
\text { Av.Rondon } \\
\text { Pacheco }\end{array}$ & $\begin{array}{l}\text { Av.João Naves } \\
\text { de Ávila/ } \\
\text { Av.Rondon } \\
\text { Pacheco }\end{array}$ \\
\hline $\begin{array}{c}\text { Av.João } \\
\text { Naves de } \\
\text { Ávila } \\
\end{array}$ & $\begin{array}{l}\text { Av.João } \\
\text { Naves de } \\
\text { Ávila }\end{array}$ & $\begin{array}{c}\text { Av.João Naves } \\
\text { entre Av.Cesário } \\
\text { Alvim e } \\
\text { Av.Floriano } \\
\text { Peixoto } \\
\end{array}$ & $\begin{array}{c}\text { Av.Afonso Pena } \\
\text { entre R.Quintino } \\
\text { Bocaiúva e } \\
\text { R.Tenente } \\
\text { Virmondes } \\
\end{array}$ & $\begin{array}{l}\text { Av.Nicomedes } \\
\text { Alves dos } \\
\text { Santos/ } \\
\text { Av.Rondon } \\
\text { Pacheco } \\
\end{array}$ & $\begin{array}{c}\text { Av. Nicomedes } \\
\text { A. Santos/ } \\
\text { Av.Rondon } \\
\text { Pacheco } \\
\end{array}$ \\
\hline $\begin{array}{l}\text { BR-365/ BR- } \\
\text { 050/ BR-452 }\end{array}$ & $\begin{array}{l}\text { BR-365/ BR- } \\
\text { 050/ BR-452 }\end{array}$ & $\begin{array}{c}\text { Av.Afonso Pena } \\
\text { entre R.Abdalla } \\
\text { Haddad e } \\
\text { R.Martinésia }\end{array}$ & $\begin{array}{c}\text { Av.João Pessoa } \\
\text { entre Av.Afonso } \\
\text { Pena e Av.João } \\
\text { Pinheiro }\end{array}$ & $\begin{array}{c}\text { Av.Floriano } \\
\text { Peixoto/ } \\
\text { Av.João Naves } \\
\text { de Ávila } \\
\end{array}$ & $\begin{array}{l}\text { Av.Antonio } \\
\text { Thomaz F. } \\
\text { Rezende/ } \\
\text { Av.Com. } \\
\text { Alexandrino } \\
\text { Garcia } \\
\end{array}$ \\
\hline $\begin{array}{l}\text { Av.Getúlio } \\
\text { Vargas }\end{array}$ & $\begin{array}{l}\text { Av. Anselmo } \\
\text { Alves dos } \\
\text { Santos }\end{array}$ & $\begin{array}{l}\text { R.Goiás entre } \\
\text { Av.Afonso Pena } \\
\text { e Av.João } \\
\text { Pinheiro }\end{array}$ & $\begin{array}{c}\text { Av.Afonso Pena } \\
\text { entre R.Abdalla } \\
\text { Haddad e } \\
\text { R.Martinésia }\end{array}$ & - & $\begin{array}{l}\text { Av.Araguari/ } \\
\text { Av.Padre Pio }\end{array}$ \\
\hline $\begin{array}{l}\text { Av. Anselmo } \\
\text { Alves dos } \\
\text { Santos } \\
\end{array}$ & $\begin{array}{l}\text { Av. Getúlio } \\
\text { Vargas }\end{array}$ & $\begin{array}{c}\text { Av.João Pinheiro } \\
\text { entre R.Olegário } \\
\text { Maciel e } \\
\text { R.Santos } \\
\text { Dumont } \\
\end{array}$ & $\begin{array}{c}\text { Av.Getúlio } \\
\text { Vargas entre } \\
\text { R.General } \\
\text { Canabarro e } \\
\text { R.Itajubá }\end{array}$ & - & 6. \\
\hline $\begin{array}{c}\text { Av. } \\
\text { Nicomedes } \\
\text { Alves dos } \\
\text { Santos }\end{array}$ & - & $\begin{array}{c}\text { Av.Floriano } \\
\text { Peixoto entre } \\
\text { R.Machado de } \\
\text { Assis e } \\
\text { R.Tenente } \\
\text { Virmondes }\end{array}$ & - & - & - \\
\hline 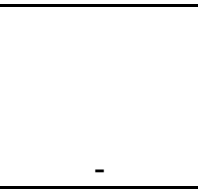 & - & $\begin{array}{c}\text { Av.Antônio } \\
\text { Thomaz } \\
\text { F.Rezende. entre } \\
\text { R.Cabanadas e } \\
\text { R.Garcia Lorca } \\
\end{array}$ & - & - & - \\
\hline- & - & $\begin{array}{c}\text { Av.Antonio } \\
\text { Thomaz F.Rez. } \\
\text { entre } \\
\text { R.Farroupilhas e } \\
\text { R.Visconde de } \\
\text { Mauá } \\
\end{array}$ & - & - & - \\
\hline - & - & $\begin{array}{c}\text { R.Duque de } \\
\text { Caxias entre } \\
\text { Av.Afonso Pena } \\
\text { e Av.João } \\
\text { Pinheiro } \\
\end{array}$ & - & - & - \\
\hline & - & $\begin{array}{c}\text { Av.Afonso Pena } \\
\text { entre R.Goiás e } \\
\text { R.Santos } \\
\text { Dumont }\end{array}$ & & & \\
\hline
\end{tabular}

Org: BERNARDINO, A.R., 2007 


\section{CAPÍTULO 4}

\section{OS BENEFÍCIOS DA ESPACIALIZAÇÃO DOS DADOS DOS ACIDENTES DE TRÂNSITO FRENTE ÀS ACÕES DO PODER PÚBLICO}

\section{1 - A interferência das condições da infra-estrutura viária nos acidentes de trânsito}

As condições físicas do sistema viário e suas particularidades locais oferecem possibilidades de redução ou aumento das ocorrências dos acidentes de trânsito, assim como, o comportamento dos usuários e dos veículos que usam esse sistema.

Estudos e pesquisas elaboradas sobre a realidade brasileira, bem como para outros países indicam que a inadequação dos veículos, da sinalização e da construção e a manutenção das vias e calçadas são fatores contribuintes em muitos acidentes (GOLD, 1998).

Com relação a obras de geometria viária se comparadas aos programas de educação e fiscalização do trânsito urbano, estas se afiguram como os investimentos que possuem certas vantagens. Primeiramente, os resultados provenientes dessas ações são imediatos e comprováveis, o que dificilmente ocorre com as campanhas publicitárias ou com os programas de educação de trânsito. Na seqüência, seus resultados apresentam condições mais duradouras e menos dependentes do investimento contínuo de recursos humanos, sendo este considerado um obstáculo, na gestão pública, no que se refere à manutenção e à avaliação de projetos implementados.

Experiências estrangeiras e brasileiras, na implantação de um grande número de intervenções viárias de diversos tipos, podem implicar uma redução 
média de $30 \%$, aproximadamente, na freqüência de acidentes nos locais tratados. Considera-se que esse nível de redução seja suficiente e justificável para investir os recursos, comparando-se o custo da implantação das intervenções e o benefício subseqüente do resultado social dos acidentes evitados (GOLD, 1998). Estima-se que, quando medidas de engenharia de tráfego são mais completas e incluem modificações urbanísticas de pequeno porte, os resultados podem chegar a ser ainda maiores (GEIPOT 1987).

Em toda a malha viária da cidade de Uberlândia, é possível verificar problemas que prejudicam a organização do espaço urbano viário e geram conflitos eminentes ao trânsito, entre eles, estão os vendedores ambulantes, com seus produtos interditando o tráfego de pedestres nas calçadas; os comerciantes, com a exposição de suas mercadorias e propagandas, em que utilizam as armações móveis ou cavaletes; além, de nem sempre, as calçadas estarem pavimentadas, e, muitas vezes, encontram-se desniveladas, o que dificulta a circulação dos pedestres, que, impedidos, valem-se da faixa de rolamento da via pela impossibilidade de sua utilização.

Quanto aos loteamentos aprovados, formando os bairros da periferia da cidade, não há preocupação com a concepção do sistema viário para as diferentes modalidades, principalmente, para as bicicletas e para os pedestres, ou seja, o plano de geometria viária é incompatível com a absorção do tráfego, ou ainda, se existe é limitado e pouco discutido.

Salienta-se que tais situações efetivas são condições que podem resultar em conflitos, o que denota a possibilidade de ocorrência de acidentes. $O$ descomprometimento relativo às conseqüências que essas situações oferecem à população é pertinente à falta de preocupação de quem realiza o planejamento em relação ao espaço destinado ao trânsito urbano, tendo em vista não somente o evento do acidente de trânsito, mas, sobretudo, os transtornos dele decorrentes. 
Gold (1998) indica algumas medidas que podem orientar o aumento da segurança durante os deslocamentos intra-viários, como os redutores de velocidades; os projetos geométricos orientados ao pedestre; os projetos geométricos para a canalização de veículos; a reorganização dos movimentos de veículos; a canalização dos fluxos de pedestres; as barreiras de segurança; iluminação e visibilidade e a sinalização provisória de segurança.

Os redutores de velocidade são dispositivos que, uma vez implantados, incomodam a quem passa em alta velocidade ou quando se detectam e se identificam veículos infratores. São caracterizados pelas fileiras de obstáculos transversais, formadas por tachões refletivos e instalados de forma contínua, em sentido transversal à via; pelas lombadas ou ondulações transversais, revelando as mais eficazes se implantadas com sinalização de advertência e o perfil adequado à via; pelas lombadas eletrônicas, que substituem a lombada física e permitem fixar a velocidade máxima desejada; pelos pardais eletrônicos que fotografam os veículos infratores; além das valetas transversais ou oblíquas, que têm um efeito bem similar ao das lombadas e necessitam, também, de uma sinalização de advertência eficiente com iluminação especial e sinal projetado.

Os projetos geométricos orientados ao pedestre consistem de pequenas obras civis como: alargamento da calçada próxima da esquina, com o intuito de reduzir o tempo e a distância da travessia do pedestre; a implantação de um refúgio (ilhotas na rua), propiciando que o pedestre realize a travessia da via em duas etapas; o uso do canteiro central em uma via, para separar os fluxos opostos de veículos e evitar as ultrapassagens na contra-mão da direção, o qual oferece também a possibilidade ao pedestre de atravessar em duas etapas; e o calçadão ou rua de pedestres, cujo objetivo é eliminar os conflitos entre pedestres e veículos em certas vias de setores de serviços e comerciais.

Referente aos projetos geométricos para a canalização de veículos, têm-se as ilhotas, que são áreas bem definidas, situadas entre as faixas de circulação de trânsito, destinadas a orientar os movimentos de veículos e servir de refúgio aos 
pedestres. Têm-se, também, as faixas de mudança de velocidade de aceleração e desaceleração, acrescentadas, principalmente, nas vias rápidas, que permitem ao condutor realizar a mudança de velocidade necessária para entrar numa via secundária ou incorporar-se ao tráfego de uma via principal; nesse sentido, essas faixas são imprescindíveis à segurança.

Sobre a reorganização dos movimentos de veículos, que tem por finalidade minimizar ou impedir o conflito entre eles, importa identificar a via de preferência, implantar os semáforos, bem como localizá-los e programá-los em acordo a outras sinalizações. Restringir a circulação, no que concerne à autorização de um sentido único de circulação na via, projetará a redução de muitas probabilidades de acidentes. Proibir as conversões, cujo objetivo é diminuir o número de conflitos entre os veículos ou entre estes e os pedestres. Sobre os estreitamentos de pista, consideram-no como um redutor de velocidade, porém, em casos avaliados, não foram constatadas reduções significativas, além das minirrotatórias, em que a técnica leva a diminuição do número de conflitos existentes em interseções nas quais a preferência não está bem definida, com baixos volumes de trânsito e elevados índices de acidentes.

As canalizações dos fluxos de pedestres, utilizando o gradil, destinam-se a encaminhar os pedestres até as travessias em locais mais seguros do que aqueles que escolheriam normalmente. $\mathrm{O}$ mesmo pode ser feito por meio das floreiras. Outro dispositivo para as canalizações dos pedestres são as passarelas e as passagens subterrâneas, que separam, em diferentes níveis, os pedestres e os veículos, maximizando a segurança dos pedestres e a capacidade das vias, ao eliminar os movimentos de conflitos.

Em se tratando das barreiras de segurança, seus objetivos levam a impedir que qualquer veículo descontrolado produza danos a pessoas ou propriedades desviando $o$ veículo que atinge a barreira, dando-lhe uma trajetória aproximadamente paralela à direção da barreira de segurança; manter os impactos sofridos pelos ocupantes de um veículo descontrolado dentro dos limites 
suportáveis; e amortecer o impacto de um veículo que se choque com a barreira, evitando que este veículo e a própria barreira se transformem em um ameaça para o resto do trânsito.

A iluminação e avisibilidade, se melhoradas, repercutem na redução dos acidentes noturnos, pois a iluminação pública insuficiente não garante a segurança no trânsito ou facilita a visibilidade de seus sinais por condutores e dos obstáculos presentes ao longo da via.

A sinalização provisória de segurança, que é usada em situações de emergência, como acidentes de circulação, obras na calçada, incêndios e inundações, devem ser eficazes para que não provoque outros acidentes pelos desvios no trânsito.

Dessa forma, para segmentos ou pontos críticos conhecidos, as intervenções na geometria viária direcionadas podem reduzir substancialmente os conflitos entre veículos e pedestres, assim como os números de registros de ocorrências dos acidentes, quando não o eliminam totalmente.

\section{2 - Ações do poder público prevendo a redução dos acidentes de trânsito}

A experiência brasileira no tratamento de acidentes de trânsito, com raras exceções, segue um modelo imediatista, no qual a solução do problema está associada à execução de práticas tradicionais no âmbito das sinalizações horizontal, vertical e/ou semafórica, associadas às correções na geometria viária, com tendência mais para a melhoria da fluidez que propriamente para a promoção da segurança dos usuários da via.

Na maioria das vezes, isso é feito sem um estudo mais apurado dos fatores que, efetivamente, contribuíram para aquelas ocorrências de trânsito, sem a 
devida avaliação da oportunidade dos custos envolvidos e/ou sem o compromisso de verificar, posteriormente, a eficácia das medidas implantadas.

\begin{abstract}
Os resultados desse processo quase sempre não são os melhores quanto à redução do número de acidentes, quer por se tratar de locais não necessariamente mais críticos em detrimento de outros efetivamente críticos, quer por envolver custos às vezes desnecessários, quer por se investir em projetos nem sempre economicamente oportuno (BRASIL, 2002. p.12).
\end{abstract}

Na última gestão administrativa (2001 a 2004) do governo municipal de Uberlândia, diferentes intervenções viárias, como parte de programas instituídos durante o período, abrangeram projetos de geometria em vários cruzamentos e trechos, bairros que foram sinalizados e vias que passaram a permissão somente em sentido único de direção.

Villela (2006) retrata sobre o programa "Mobilidade Urbana e Segurança", que foi implementado em Uberlândia, a partir de 2002, cujas ações concretas vinculadas aos projetos desse programa foram:

- execução de sinalização de trânsito (vertical e horizontal) em 70\% dos bairros, incluindo todos os cruzamentos do sistema viário e pontos considerados críticos;

- implementação da CTA, possibilitando melhor fluidez no tráfego viário e segurança na área central;

- implantação da sinalização indicativa para facilitar a circulação aos locais de interesse do condutor;

- implantação de ciclovias ou ciclofaixas, nos bairros Dom Almir, Morava Nova e Lagoinha;

- realização de obras viárias: rotatória do posto "da matinha", acesso aos bairros Mansões Aeroporto, Ipanema, Luizote de Freitas, Patrimônio, Cidade Jardim, entre outros;

- correções e canalizações por meio da intervenção na geometria viária nas Av. Nicomedes Alves dos Santos e Rondon Pacheco;

- implantação do viaduto de acesso aos bairros Guarani e Tocantins; 
- reurbanização da Av. João Pinheiro, com tratamento adequado aos pedestres, como acessibilidade a pessoas portadoras de deficiência física e visual, humanização da avenida e priorização do transporte urbano coletivo;

- implantação de 72 pontos de controle de velocidade mediante dispositivos eletrônicos;

- aumento do número de veículos acessíveis ao portador de deficiência, por meio do "SIT para todos";

- sinalização de todos os pontos de parada do transporte coletivo e implantação de vários abrigos;

- implantação do sistema de monitoramento por GPS (Global Position Sistem) nos veículos do Sistema Integrado de Transportes (SIT);

Desse elenco, observa-se que os projetos como, o da CTA e o dos pontos de controle de velocidades por meio dos dispositivos eletrônicos, foram implementados no ano de 2000, e, assim, como foi dada continuidade nas atividades vinculadas aos projetos, mesmo na mudança administrativa municipal, fizeram parte na listagem das ações concretas desta gestão (2001 a 2004).

Os projetos de geometria viária executados tiveram como obra de infraestrutura: abertura e fechamento de canteiro central; abertura de canteiro lateral; fechamento parcial de canteiro lateral; implantação de rotatórias; ampliação e adequação da faixa de acomodação do canteiro central; ampliação da faixa de tráfego; alargamento das aberturas de canteiro central; avanço e implantação de calçadas; correção do raio de giro; ilha de proteção à travessia de pedestre; passarela no canteiro central; realocação de abertura de canteiro central; correção de canteiro central, ilha divisória de fluxo de veículo. Pelo quadro 53 podem ser identificadas as vias que receberam esses tratamentos. 
Quadro 53 - Projetos de geometria viária executados, 2001 a 2004

\begin{tabular}{|c|c|c|}
\hline $\begin{array}{l}N^{\circ} . \\
\text { Ord. }\end{array}$ & Identificação das vias & Tipo de obra realizada \\
\hline 1 & Al. Uberaba x Berthold Thomaz Aguiar & Abertura - canteiro central \\
\hline 2 & Al. Uberaba x César Finotti & Implantação de rotatória \\
\hline 3 & Al. Uberaba $\mathrm{x}$ Juracy J Resende & Implantação de rotatória \\
\hline 4 & Antônio Rufino x João Bernardes Silva & Implantação de rotatória \\
\hline 5 & $\begin{array}{l}\text { Antônio Thomaz F. Rezende } x \\
\text { Quilombo dos Palmares }\end{array}$ & Fechamento - canteiro central \\
\hline 6 & $\begin{array}{l}\text { Arnaldo Godoy de Souza (entre } \\
\text { Alamandas e Camomilas) }\end{array}$ & $\begin{array}{l}\text { Ampliação - faixa de acomodação do canteiro } \\
\text { central }\end{array}$ \\
\hline 7 & Atahíde de Deus Vieira x Rio Gde d Sul & $\begin{array}{l}\text { Abertura - canteiro central / Implantação de } \\
\text { ilha }\end{array}$ \\
\hline 8 & $\begin{array}{l}\text { Belarmino Cotta Pacheco x Sebastião } \\
\text { Rangel }\end{array}$ & Implantação de rotatória \\
\hline 9 & Bélgica x Constantinopla & Avanço de calçada \\
\hline 10 & BR 050/ BR 365/ BR 452 & Implantação de rotatória \\
\hline 11 & $\begin{array}{l}\text { Cap. Pedro Manso x João S. Rodrigues } \\
\text { da Cunha }\end{array}$ & Implantação de rotatória \\
\hline 12 & Cartola x Noel Rosa & Correção do raio de giro \\
\hline 13 & Cesário Crosara x Pedro M. Oliveira & Abertura - canteiro central \\
\hline 14 & $\begin{array}{l}\text { Com. Alexandrino Garcia x Claudemiro } \\
\text { José de Souza }\end{array}$ & Abertura - canteiro central \\
\hline 15 & Dr. Vicente Sales Guimarães & Correção canteiro central \\
\hline 16 & Engenheiro Azelli x Elpídio A. Freitas & Implantação de calçada \\
\hline 17 & Engenheiro Azelli x Paes Leme & Avanço de calçada \\
\hline 18 & Espanha (entre Atenas e Tunísia) & Abertura - canteiro central \\
\hline 19 & Espanha (entre Grécia e Atenas) & Abertura - canteiro central \\
\hline 20 & Espanha x Europa x Montreal & Implantação de rotatória \\
\hline 21 & Espanha x Viena & Fechamento - canteiro central \\
\hline 22 & Francisco Galassi x Liberdade & Implantação de rotatória \\
\hline 23 & Gameleiras $\mathrm{x}$ Jorge Cauhy & Abertura - canteiro central \\
\hline 24 & Genarino Cazabona x Luís José Alves & Implantação de rotatória \\
\hline 25 & Genarino Cazabona x Paulo L Rotelli & Implantação de rotatória \\
\hline 26 & $\begin{array}{l}\text { Getúlio Vargas x Advogado x Olímpio } \\
\text { de Freitas }\end{array}$ & Implantação de rotatória \\
\hline 27 & Getúlio Vargas x Gameleiras & $\begin{array}{l}\text { Avanço de calçada / faixa de acomodação / } \\
\text { Abertura canteiro central }\end{array}$ \\
\hline 28 & Himalaia $\mathrm{x}$ via acesso Mans. Aeroporto & Implantação de rotatória \\
\hline 29 & Holanda $\times$ Constantinopla & Abertura - canteiro central \\
\hline 30 & Imbaúbas x Aspirante Mega & Implantação de rotatória \\
\hline 31 & Israel x Três Poderes x Guiné & Abertura - canteiro central \\
\hline 32 & João Balbino x Ana Godoy & Abertura - canteiro central \\
\hline 33 & $\begin{array}{l}\text { João Naves de Ávila (entre Floriano e } \\
\text { C. Alvim) }\end{array}$ & Fechamento - canteiro central \\
\hline 34 & $\begin{array}{l}\text { João Naves de Ávila (entre Floriano e } \\
\text { Cesário Alvim) }\end{array}$ & $\begin{array}{l}\text { Ampliação - faixa de acomodação canteiro } \\
\text { central }\end{array}$ \\
\hline 35 & $\begin{array}{l}\text { João Naves de Ávila (todas as } \\
\text { aberturas c. central) }\end{array}$ & Alargamento das aberturas \\
\hline 36 & $\begin{array}{l}\text { João Naves de Ávila x Belarmino C } \\
\text { Pacheco }\end{array}$ & $\begin{array}{l}\text { Implantação - Ilha de proteção a travessia de } \\
\text { pedestres }\end{array}$ \\
\hline 37 & João N. Ávila x Belarmino C Pacheco & Implantação - Passarela canteiro central \\
\hline
\end{tabular}


Cont. Quadro 53

\begin{tabular}{|c|c|c|}
\hline $\begin{array}{l}N^{\circ} . \\
\text { Ord. }\end{array}$ & Identificação das vias & Tipo de obra realizada \\
\hline 38 & $\begin{array}{l}\text { João Naves de Ávila x Belarmino C } \\
\text { Pacheco }\end{array}$ & $\begin{array}{l}\text { Relocação de abertura canteiro central / } \\
\text { ampliação faixa de acomodação }\end{array}$ \\
\hline 39 & João Naves de Ávila x João Pinheiro & Avanço de calçada \\
\hline 40 & $\begin{array}{l}\text { João Naves de Ávila x Manoel dos } \\
\text { Santos }\end{array}$ & Abertura - canteiro central \\
\hline 41 & $\begin{array}{l}\text { João Naves de Ávila x Manoel dos } \\
\text { Santos }\end{array}$ & Implantação de faixa de acomodação \\
\hline 42 & João Naves de Ávila x Timbiras & Avanço de calçada \\
\hline 43 & $\begin{array}{l}\text { João Naves de Ávila x Ubiratan H de } \\
\text { Castro }\end{array}$ & Avanço de calçada \\
\hline 44 & João Naves de Ávila x Vitalino R Carmo & Fechamento - canteiro central \\
\hline 45 & João Pinheiro (centro) & Requalificação \\
\hline 46 & $\begin{array}{l}\text { Joaquim L Camargos x Imbaúbas x D } \\
\text { Machado }\end{array}$ & Implantação de rotatória \\
\hline 47 & $\begin{array}{l}\text { Joaquim L de Camargo (entre Luzia N } \\
\text { Jesus e Paulo L Rotelli) }\end{array}$ & Implantação de calçada \\
\hline 48 & $\begin{array}{l}\text { Joaquim L de Camargo x Waldemar } \\
\text { Silva }\end{array}$ & Fechamento - canteiro central \\
\hline 49 & José Fonseca e Silva x Adelita C Pfeifer & Fechamento - canteiro central \\
\hline 50 & $\begin{array}{l}\text { José Fonseca e Silva x Adomervil } \\
\text { Moreira (1) }\end{array}$ & Fechamento - canteiro central \\
\hline 51 & $\begin{array}{l}\text { José Fonseca e Silva x Adomervil } \\
\text { Moreira (2) }\end{array}$ & Fechamento - canteiro. central \\
\hline 52 & $\begin{array}{l}\text { José Fonseca e Silva x Albacis } \\
\text { Cavalcante }\end{array}$ & Fechamento - c. central \\
\hline 53 & José Fonseca e Silva x Benedito Marra & Abertura - canteiro central \\
\hline 54 & José Fonseca e Silva x Calil Abrão & Fechamento - canteiro central \\
\hline 55 & $\begin{array}{l}\text { José Fonseca e Silva x Carlos } \\
\text { Tomazelli }\end{array}$ & Fechamento - canteiro central \\
\hline 56 & José Fonseca e Silva x Djanir Grama & Abertura - canteiro central \\
\hline 57 & $\begin{array}{l}\text { José Fonseca e Silva x Estefânio } \\
\text { Bernardes }\end{array}$ & Fechamento - canteiro central \\
\hline 58 & José Fonseca e Silva x Matheus Vaz & Fechamento - canteiro central \\
\hline 59 & $\begin{array}{l}\text { José Fonseca e Silva x Maximiliano } \\
\text { Carneiro }\end{array}$ & Abertura - canteiro central \\
\hline 60 & $\begin{array}{l}\text { José Fonseca e Silva x Osvaldo } \\
\text { Samora }\end{array}$ & Abertura / adequação do canteiro central \\
\hline 61 & José Pires Defensor & Correção canteiro central \\
\hline 62 & $\begin{array}{l}\text { Marcos de Freitas Costa x Horácio } \\
\text { Rezende }\end{array}$ & $\begin{array}{l}\text { Adequação canteiro central / faixa de } \\
\text { acomodação }\end{array}$ \\
\hline 63 & $\begin{array}{l}\text { Marcos de Freitas Costa x Poços de } \\
\text { Caldas }\end{array}$ & $\begin{array}{l}\text { Adequação canteiro central / faixa de } \\
\text { acomodação }\end{array}$ \\
\hline 64 & Matheus Vaz x Geraldino Carneiro & Correção do raio de giro \\
\hline 65 & Moedas x João Borges Cunha & Abertura - canteiro central \\
\hline 66 & $\begin{array}{l}\text { Nicomedes Alves dos Santos X } \\
\text { Francisco Galassi }\end{array}$ & $\begin{array}{l}\text { Correção do raio de giro / faixa de } \\
\text { acomodação }\end{array}$ \\
\hline 67 & $\begin{array}{l}\text { Nicomedes Alves dos Santos x } \\
\text { Liberdade x Antônio M Povoa }\end{array}$ & Implantação de rotatória \\
\hline 68 & $\begin{array}{l}\text { Nicomedes Alves dos Santos } \mathrm{x} \\
\text { Presidente Médici }\end{array}$ & $\begin{array}{l}\text { Implantação - faixa de acomodação canteiro } \\
\text { central }\end{array}$ \\
\hline
\end{tabular}


Cont. Quadro 53

\begin{tabular}{|c|c|c|}
\hline $\begin{array}{l}N^{\circ} . \\
\text { Ord. }\end{array}$ & Identificação das vias & Tipo de obra realizada \\
\hline 69 & $\begin{array}{l}\text { Nicomedes Alves dos Santos x Rafael } \\
\text { M Neto }\end{array}$ & Ilha divisória de fluxo/ faixa de acomodação \\
\hline 70 & $\begin{array}{l}\text { Nicomedes Alves dos Santos } \mathrm{x} \\
\text { Vinhedos }\end{array}$ & $\begin{array}{l}\text { Abertura/ Implantação - faixa de acomodação c } \\
\text { canteiro central }\end{array}$ \\
\hline 71 & Padre Pio x Praça Lázaro Zamon & correção da calçada \\
\hline 72 & Paraná (entre Rondon e C. Alvim) & Implantação - canteiro central \\
\hline 73 & Pça Arlindo Magalhães Lima & Fechamento de via \\
\hline 74 & Piauí x Ferrovia & Abertura de via \\
\hline 75 & Rio Grande do Norte x Ferrovia & Abertura de via \\
\hline 76 & Rondon x Anselmo Alves dos Santos & Abertura canteiro lateral \\
\hline 77 & Rondon x Anselmo Alves dos Santos & Raio de giro - canteiro central \\
\hline 78 & Rondon $\mathrm{x}$ Augusto César & Abertura - canteiro lateral \\
\hline 79 & Rondon $x$ Augusto César & Fechamento parcial - canteiro lateral \\
\hline 80 & Rondon $\mathrm{x}$ Augusto César & Abertura parcial - canteiro lateral \\
\hline 81 & Rondon x Eduardo Felice & Abertura canteiro central \\
\hline 82 & Rondon x Eduardo Felice & Abertura canteiro lateral \\
\hline 83 & Rondon x Geraldo M Batista & Adequação da rotatória \\
\hline 84 & Rondon x Mário Resende Ribeiro & $\begin{array}{l}\text { Ampliação - faixa de acomodação canteiro } \\
\text { central }\end{array}$ \\
\hline 85 & Rondon $\mathrm{x}$ Nicomedes & Ampliação - faixa de tráfego \\
\hline 86 & Rondon $\times$ Nicomedes & Raio de giro - canteiro central \\
\hline 87 & Rondon x Paraúna & Abertura - canteiro lateral \\
\hline 88 & Rondon $\times$ Santos Dumont & $\begin{array}{l}\text { Implantação - faixa de acomodação canteiro } \\
\text { central }\end{array}$ \\
\hline 89 & Rondon $\mathrm{x}$ Santos Dumont & Abertura canteiro lateral \\
\hline 90 & Saldanha Marinho x Geraldo Abrão & Implantação de rotatória \\
\hline 91 & $\begin{array}{l}\text { São Francisco de Assis } x \\
\text { Mal.Mascarenhas }\end{array}$ & Avanço de calçada \\
\hline 92 & São Francisco de Assis x Teófilo Alves & Fechamento de via \\
\hline 93 & $\begin{array}{l}\text { Segismundo Pereira } \times \text { Maria das Dores } \\
\text { Dias }\end{array}$ & $\begin{array}{l}\text { Implantação - faixa de acomodação canteiro } \\
\text { central }\end{array}$ \\
\hline 94 & $\begin{array}{l}\text { Segismundo Pereira x Pedro José } \\
\text { Samora }\end{array}$ & Implantação de passarela canteiro central \\
\hline 95 & Seme Simão $x$ Continental & Implantação de rotatória \\
\hline 96 & Sideral $\mathrm{x}$ via acesso Ipanema & Implantação de rotatória \\
\hline 97 & Sílvio Rugani x Cel. Tobias Junqueira & Adequação da rotatória \\
\hline 98 & Travessa Frutal & Fechamento de via / Implantação de calçada \\
\hline 99 & Uirapuru x José de Oliveira Pinto & Fechamento - canteiro central \\
\hline
\end{tabular}

Fonte: SETTRAN, 2004

Org: BERNARDINO, A.R., 2007

As identificações das vias que sofreram as intervenções de geometria pelo órgão executor (SETTRAN), acima descritas, foram arroladas como cruzamentos, sendo que, para cada tipo de intervenção, a influência pode estar diretamente relacionada ao próprio cruzamento, ao trecho ou à via, pois abrangem as 
condições de fluxo de tráfego, de segurança e sinalização viária para toda a extensão do trecho ou local específico, como é o cruzamento.

Analisando as obras de geometria executadas de 2001 até o ano de 2004, indicadas no quadro acima, referentes às vias críticas identificadas para o ano de 2004 (cf. quadros 52 e 53), mostra-se que, nesse período, as intervenções executadas abrangeram todas as vias que foram identificadas aqui como críticas. No quadro 53 podem ser verificados os tipos de obras que foram realizadas.

As intervenções de geometria executadas, também no período de 2000 a 2004, que influenciaram nos trechos críticos aqui inventariados (cf. quadro 52 e 53), abrangeram as Av. João Naves de Ávila entre Av. Cesário Alvim e Av. Floriano Peixoto e Av. João Pinheiro entre R. Olegário Maciel e R. Santos Dumont. Nessas, a intervenção da requalificação atingiu, pois foi realizada na extensão da Av. João Pinheiro, que se alonga pela área central, ou seja, desde o Terminal Central até a Pça. Clarimundo Carneiro. Os demais trechos não receberam intervenções, que pode ser conferidos no quadro 53.

$\mathrm{Na}$ comparação dos cruzamentos que sofreram as intervenções executadas pela SETTRAN, de 2001 a 2004, em relação aos cruzamentos críticos indicados neste estudo (cf. quadro 52), tem-se que o cruzamento da Av. Rondon Pacheco com a Av. Nicomedes Alves dos Santos recebeu tratamento, no que se refere à ampliação da faixa de tráfego e ao raio de giro do canteiro central (cf. figura 10). Para o cruzamento da Av. João Naves de Ávila com a Av. Floriano Peixoto, a ampliação da faixa de acomodação, utilizando parte do canteiro central, serviu para oferecer mais fluidez ao tráfego deste local, principalmente nos horários de pico.

Os cruzamentos apresentados com situação crítica neste estudo, como o da Av. João Naves de Ávila com a Av. Rondon Pacheco (cf. figura 7), Av. Antônio Thomaz Ferreira de Rezende com Av. Comendador Alexandrino Garcia (cf. figura 9) e Av. Araguari com R. Padre Pio (cf. figura 11), não foram citados na listagem 
de intervenções de geometria viária executadas. Mas, o cruzamento da Av. João Naves de Ávila com Av. Rondon Pacheco, recentemente recebeu tratamento devido ao início da operação do Corredor Exclusivo de Ônibus da João Naves.

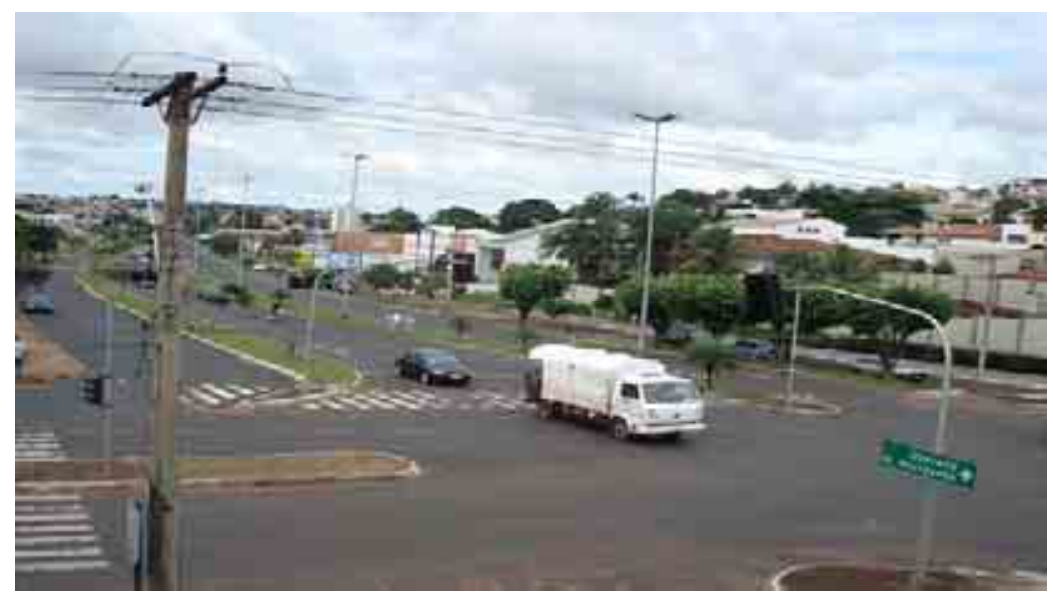

Figura 10 - Cruzamento da Av. Rondon Pacheco com a Av. Nicomedes A. dos Santos, Uberlândia, 2007

Fonte: foto da autora, 2007

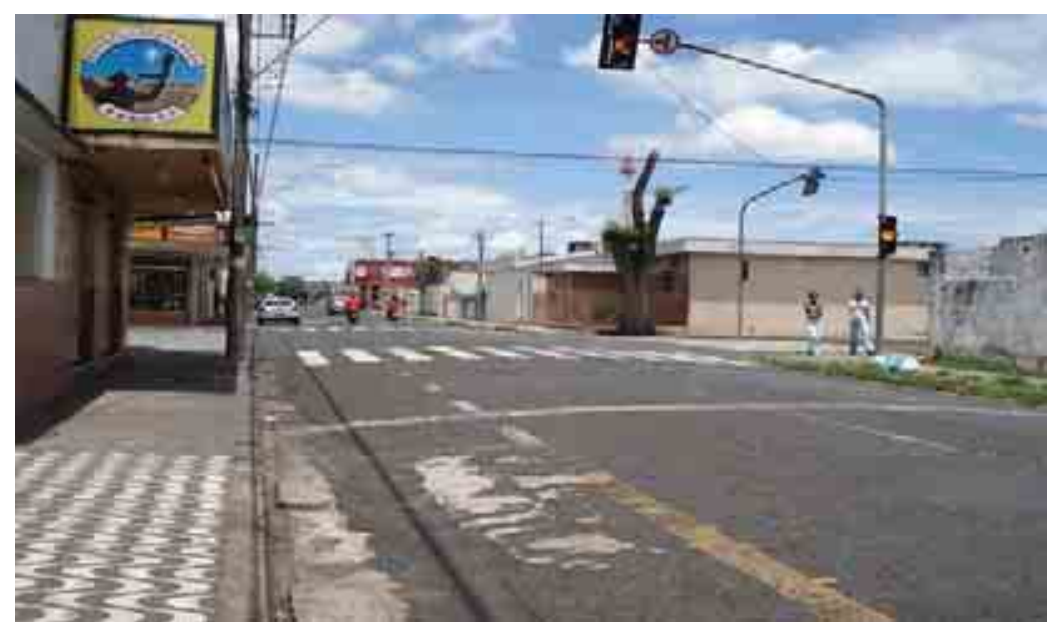

Figura 11- Cruzamento da Av. Araguari com R. Padre Pio, Uberlândia, 2007

Fonte: foto da autora, 2007 
Em setembro de 2006, foi inaugurado o Corredor Estrutural João Naves. O projeto compreendido com a faixa exclusiva para os ônibus que trafegam pela Av. João Naves de Ávila (cf. figura 12), servida de 13 estações de embarque e desembarque, fechadas, sendo três de transferências, totalizando 14,8 quilômetros de extensão.

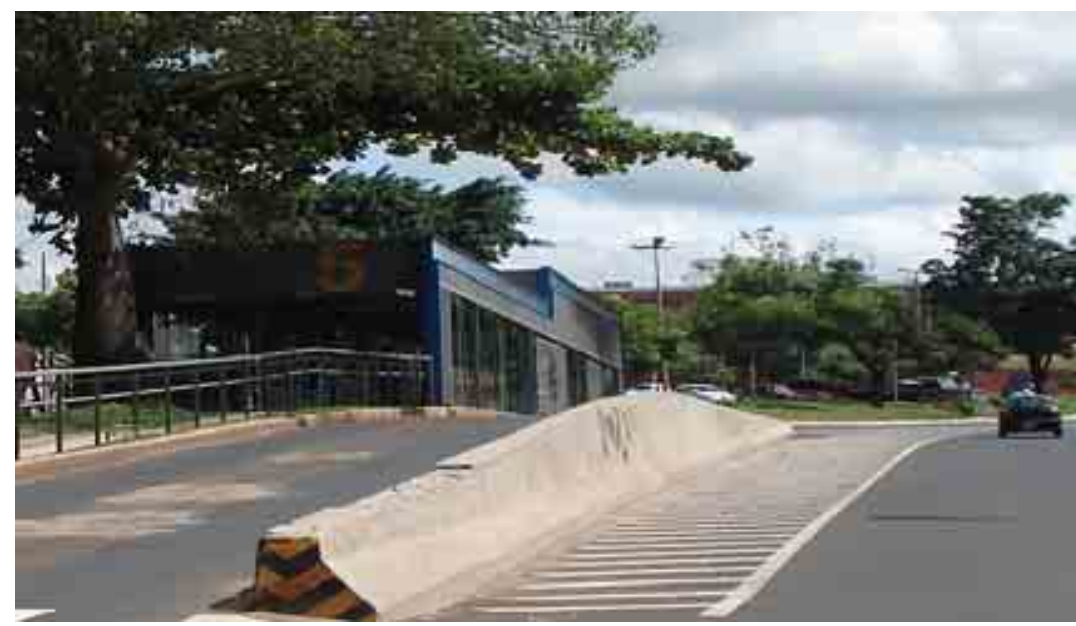

Figura 12 - Estação 5 para embarque e desembarque dos usuários do transporte coletivo urbano, no Corredor Estrutural da Av. João Naves de Ávila, Uberlândia, 2007 Fonte: foto da autora, 2007

Equipamentos importantes foram instalados no cruzamento da Av. João Naves com Av. Rondon Pacheco, como os semáforos temporizados, que permitem aos condutores programar com mais confiança a travessia do cruzamento, ou mesmo sua parada. Outra alteração foi de que os movimentos de conversões da Av. João Naves de Ávila, neste cruzamento, foram proibidos.

Classifica-se esse projeto, o de maior relevância e impacto para a cidade nesta administração municipal, proposto pela SETTRAN, como uma melhoria no desempenho operacional, na humanização no trânsito e na melhor acessibilidade ao pedestre.

Os bairros que foram sinalizados no período de 2002 a 2004 contemplaram as sinalizações horizontais e verticais, cujas identificações estão abaixo relacionadas (SETTRAN, 2004): 
Aclimação, Alvorada, Brasil, Canaã, Centro, Chácaras Tubalina, Cidade Jardim, Cruzeiro do Sul, Custódio, D. Industrial, Dom Almir, Dona Zulmira, Embra, Esperança, Granada, Ipanema, Jaraguá, Jardim América, Jardim Botânico, Jardim Brasília, Jardim das Palmeiras, Jardim Karaíba, Jardim Patrícia, Jardim Holanda, Lagoinha, Laranjeiras, Liberdade, Luizote, Mansões Aeroporto, Mansour, Marta Helena, Martins, Minas Gerais, Morada da Colina, Morumbi, Nossa Senhora das Graças, Osvaldo Resende, Pacaembu, Pampulha, Patrimônio, Planalto, Residencial Camaru, Roosevelt, Santa Luzia, Santa Mônica, Santa Rosa, São Jorge, São Lucas, Saraiva, Tabajaras, Taiaman, Tibery, Umuarama, Vigilato Pereira.

A manutenção da sinalização viária, geralmente, é relegada a segundo plano, mas, de grande importância, pois ela torna o trânsito mais respeitoso. Qualquer tipo de sinalização deve estar em boas condições para conseguir o efeito desejado, assim como a sua correta visualização. Dessa forma, é notório o estabelecimento de freqüências nas intervenções de manutenção, principalmente em locais que demandem maior volume de veículos e pedestres. A figura abaixo expõe uma intervenção realizada na Av. Antônio Thomaz Ferreira de Rezende no cruzamento com a Av.Comendador Alexandrino Garcia, cujo movimento de veículos de carga e de passeio é intenso.

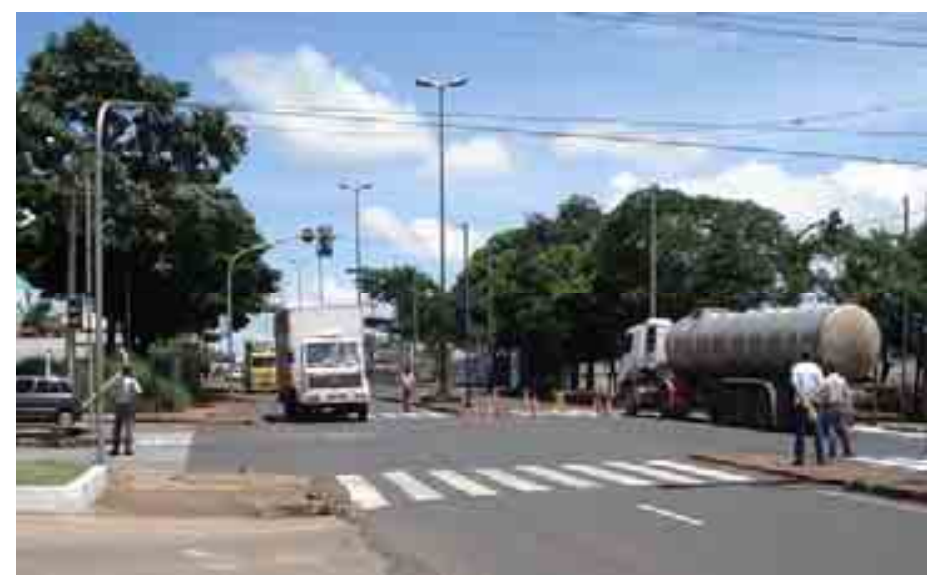

Figura 13 - Manutenção na sinalização horizontal. Cruzamento da Av. Antônio Thomaz Ferreira de Rezende com Av. Comendador Alexandrino Garcia, Uberlândia, 2007 Fonte: foto da autora, 2007 
Acrescentam-se outras intervenções realizadas no sistema viário referentes às alterações nas vias em que passou a ser permitido somente um sentido de direção. O quadro 54 apresenta os logradouros que receberam tratamento.

Das vias identificadas como críticas, neste estudo, para o ano de 2004, (cf. quadro 53), e comparando com estas que sofreram intervenções de 2001 a 2004 (cf. quadro 54), temos que elas não ocorrem nesta descrição, pois todas as vias que se apresentaram como críticas possuem as duas mãos de direção com canteiro central dividindo-as, e esta intervenção refere-se à proibição de um sentido de direção na via selecionada para tal.

Conforme Mesquita (2005), o programa foi elaborado com a proposição de romper o paradigma das intervenções isoladas e abandonar a crença no tratamento somente das conseqüências dos acidentes de trânsito, sem considerar a existência da opção da cidade pelo automóvel, que deteriora o meio ambiente urbano, causa acidentes e reproduz modelos de exclusão social. 
Quadro 54 - Vias que passaram para sentido único de direção, 2001 a 2004

\begin{tabular}{||l|c||}
\hline \multicolumn{1}{|c|}{ Identificaçao da via } & Bairro \\
\hline Mário Rezende Ribeiro & Cazeca \\
\hline Francisco Zumpano & Cazeca \\
\hline Ipiranga & Cazeca \\
\hline Cel. Antônio Alves Pereira (trecho) & Lídice \\
\hline Rezende & Centro \\
\hline José Camin & Centro \\
\hline Olegário Maciel & Lídice \\
\hline Duque de Caxias & Lídice \\
\hline Nicomedes Alves dos Santos & Fundinho \\
\hline Augusto César & Fundinho \\
\hline República do Piratiní & Nossa Sra. das Graças \\
\hline Pedro Quirino da Silva & Nossa Sra. das Graças \\
\hline Altivo Ferreira Batista & São Jorge \\
\hline Célio Pontes & São Jorge \\
\hline Padre Pio & Osvaldo Resende \\
\hline Engenheiro Azelli (trecho) & Osvaldo Resende \\
\hline São Francisco de Assis & Saraiva / Lagoinha \\
\hline Pio XII & Lagoinha \\
\hline Afrânio Rodrigues da Cunha & Tabajaras \\
\hline Manoel dos Santos & Saraiva \\
\hline Cel. Antônio Alves Pereira & Saraiva \\
\hline Carrijos & Saraiva \\
\hline Quintino Bocaiúva & Saraiva \\
\hline Benjamin Alves dos Santos & Saraiva \\
\hline Machado de Assis & Saraiva \\
\hline Olegário Maciel & Saraiva \\
\hline Tabajaras & Saraiva \\
\hline Tapuios & Saraiva \\
\hline Timbiras & Saraiva Jesus \\
\hline Marciano de Ávila & \\
\hline Mauá & \\
\hline Fonte: SETs \\
\hline
\end{tabular}

Fonte: SETTRAN, 2004

Org: BERNARDINO, A.R., 2007

Tais intervenções foram realizadas na intenção de abranger as medidas propostas para a redução dos acidentes de trânsito e obter uma visão global dos problemas de segurança no trânsito. O programa baseou-se na fundamentação de uma matriz de relacionamento, que conjuga o máximo de variáveis ligadas à mobilidade urbana, envolvendo não somente os aspectos de circulação, mas os transportes em si e seus impactos na organização do espaço urbano. 
O programa "Mobilidade Urbana e Segurança" foi implementado até fins do ano de 2004, quando sofreu alteração decorrente da mudança da administração municipal, cujo reinício ocorreu no início de 2006.

Ainda considerado como intervenção no trânsito urbano de Uberlândia, salienta-se o investimento direcionado aos equipamentos de fiscalização eletrônica de controle de velocidade e avanço de sinal. Desde o ano de 2001, foram instalados, nas principais vias que absorvem grande fluxo de veículos e oferecem possibilidades de alcance de altas velocidades, os equipamentos de fiscalizações eletrônicas, como o "radar fixo". As vias que receberam esses monitoramentos, até o ano de 2004, podem ser observadas por meio do mapa 37. Para os cruzamentos considerados pela SETTRAN, com mais necessidade de fiscalização contínua do tráfego viário, também, foram instalados equipamentos que fiscalizam os avanços de sinais (cf. mapa 38). 
A SETTRAN (2005), visando à maior segurança no trânsito de Uberlândia e, consequentemente, menor número de ocorrências de acidentes, propõe a celebração das parcerias nas áreas de Educação, Engenharia de Tráfego, Fiscalização, cujos objetivos devem conduzir a:

- desenvolver estudos e treinamentos que visem à melhoria do ambiente viário, principalmente no que se refere à segurança de circulação, ou seja, condições das vias, sinalizações e operações;

- desenvolver metodologia, utilizando-se de estatísticas confiáveis e sistematizadas, de forma a identificar, com precisão, os fatores contribuintes dos acidentes de trânsito e planejar ações para monitoramento e avaliações; - implementar medidas de engenharia de tráfego de maior abrangência e baixo custo para o tratamento de locais de alto risco e com grande exposição ao perigo;

- desenvolver ações conjuntas de médio e longo prazos para a construção de um sistema viário mais seguro.

Além disso, a educação para o trânsito constitui um grande potencial para promover a efetivação das medidas a serem tomadas, principalmente, se for proposta de forma sistêmica e não independente como vem sendo tratada no Brasil.

A educação para o trânsito torna-se um instrumento indispensável para a prática da cidadania e para uma nova mobilidade fundamentada na utilização maior dos meios não motorizados, pautados na indução do respeito ao público e direcionando à lógica da comunidade e coletividade (VILLELA, 2006).

Junqueira (2003, p.164) destaca a importância da educação e da cidadania em relação à circulação viária:

Educação para a cidadania. Não a educação tradicional de trânsito onde o que interessa é o comportamento adequado do pedestre servindo aos interesses do tráfego veicular. Incorporar valores e comportamentos, tais como a primazia do pedestre sobre o automóvel 
quando a sua travessia é ainda um desafio. $O$ respeito à faixa de pedestre ou mesmo onde não há faixa como preconizado pelo Código de Trânsito Brasileiro, é tarefa por fazer. A educação para os participantes da circulação ultrapassa os limites e recordes artificiais apresentados pelo trânsito.

Em meados do ano de 2002, a SETTRAN instituiu um programa de educação para o trânsito de forma a abranger, estrategicamente, a cidade por meio da participação das escolas, envolvendo os professores, os alunos e pais e a comunidade em geral. Na proposta de uma gincana pedagógica, a qual serviu de instrumento para informar sobre os aspectos e comportamentos seguros a serem adotados no trânsito, o público alvo foram crianças de $5^{\mathrm{a}}$. a $8^{\mathrm{a}}$. séries do ensino fundamental, com duração de um ano letivo.

O objetivo desse projeto é despertar o interesse da comunidade escolar para as questões relativas ao comportamento e segurança no trânsito, enfocando a postura do cidadão, na condição de usuário das vias públicas nas situações de pedestres, ciclistas, motociclistas, condutores de veículos ou passageiros.

Para a realização desse projeto, elaboraram-se materiais pedagógicos, que foram subsídio para os alunos conhecerem a realidade do trânsito brasileiro, além de orientações para pesquisas extras sobre o trânsito de Uberlândia. Palestras e apresentações teatrais sobre a temática foram preparadas e orientadas.

Em 2003 e 2004, houve a continuidade da Gincana de Educação para o Trânsito, e outro projeto, em parceria com a FIAT Automóveis e o Projeto "Empresa", teve seu início em 2003. Este foi implementado por meio de palestras informativas visando à educação para o trânsito no quesito comportamento e segurança no trânsito. Foi destaque a participação de um grupo teatral que levou de forma lúdica orientações importantes aos funcionários. Nesse período, ainda como parte da campanha educativa, abordou-se o tema a referente ao "consumo de álcool e direção" diretamente nos bares, quando nas proximidades de feriados, como os de carnaval ou outros prolongados. 
A campanha da faixa de pedestre iniciou-se no ano de 2002, e falhas significativas foram reveladas, distorcendo conceitos básicos, como a preferência do pedestre na faixa do pedestre e a obrigatoriedade do respeito à sinalização quando a sua existência nas faixas de pedestres com semáforos. Muitos acidentes ocorreram demonstrando ineficácia da campanha (VILLELA, 2006).

É notório considerar que a mudança de comportamento é lenta, e seria necessário um trabalho permanente de educação para o trânsito, para que a cultura de travessia e respeito à faixa de pedestres fosse introduzida e assimilada junto às ações imediatas dos cidadãos implicando todos que utilizam o sistema viário.

Outros projetos foram desenvolvidos no ano de 2005 e em 2006. A divisão responsável pelo setor na SETTRAN mudou de sede, sendo inserida na Divisão de Operação de Tráfego (DOT), que buscou a aproximação do trabalho de educação para o trânsito ao de fiscalização por intermédio dos agentes de trânsito.

Objetivando combinar esforços de diferentes setores, em dezembro de 2005, foi proposta a criação do Conselho Municipal de Educação para o Trânsito, cujo destaque é a junção de pessoas ligadas a diferentes áreas do conhecimento, com o intuito de minimizar os conflitos durante os deslocamento, reduzir os acidentes de trânsito ocorridos na cidade e aprimorar a prática interdisciplinar de aplicação da metodologia a ser utilizada para essa finalidade.

De acordo com Villela (2006), os seguintes projetos relacionados com a educação para o trânsito estão sendo desenvolvidos, a saber:

- campanha nas faixas de pedestres;

- realização de blitz educativa;

- participação em palestras e stands informativos durante a Semana Interna de Prevenção de Acidente (SIPAT), nas empresas; 
- projeto "transitolândia" locado no espaço de vivência do Parque do Sabiá;

Ainda que a educação para o trânsito caminhe a passos lentos, é importante ressaltar que a problemática referente aos conflitos entre veículos $\mathrm{e}$ pedestres também está diretamente ligada à ineficiência do planejamento e da fiscalização, que poderiam minimizar os abusos cometidos no trânsito, os quais repercutem na desorganização da circulação viária pública e na falta de controle que se encontra presente na esfera da administração pública.

\section{3 - Contribuições provenientes da espacialização dos dados dos acidentes de trânsito}

A abordagem clássica para o conhecimento dos dados sociais, econômicos e ambientais utiliza técnicas estatísticas bem estabelecidas, porém não permite considerar o espaço geográfico. Assim sendo, dada à importância do reconhecimento do local onde ocorrem os eventos, as técnicas usadas partem do princípio de que "há algo especial com dados espaciais", e que "o local faz a diferença".

Para Zanotelli \& Coutinho (2003), a representação espacial propicia uma leitura sintética e analítica do fenômeno e, por meio de associação e comparação entre os diversos lugares, em diferentes momentos, há possibilidade de compreender as causas da diferenciação sócio-espacial dos eventos e, neste caso, dos locais em que ocorrem os acidentes com maior freqüência.

Questões vinculadas à análise espacial de dados geográficos que levam em conta a localização espacial do fenômeno em estudo tencionam incorporar o espaço à analise que se deseja fazer. 
O mapa é um meio eficaz de sensibilizar os órgãos envolvidos com a segurança viária, além de os dados da espacialização dos acidentes de trânsito permitir uma visualização direta no ponto crucial da questão. Acrescenta-se que é um meio que possibilita a leitura da informação por vários profissionais de áreas que trabalham com essa questão, pois proporciona um diagnóstico rápido, indicando locais específicos, além de auxiliar no desenvolvimento da discussão.

É importante que isso seja feito de forma interdisciplinar, pois, no espaço, confluem variáveis que precisam ser consideradas e assimiladas sob diferentes abordagens pragmáticas. Deve-se considerar, ainda, que as ocorrências dos acidentes de trânsito distribuem-se por toda a cidade, e sua descrição visual e espacial contribui na tomada de decisões que abarcam tal fenômeno.

É salutar que mesmo o Estado ou a sociedade civil desenvolvam ações preventivas para que o número de vítimas reduza. Assim, Santos (1999:17) comenta que

[...] o primeiro passo é a busca do conhecimento do contexto onde a violência acontece e a identificação de áreas onde estas situações compartilham uma dinâmica particular. Só a partir desse conhecimento será possível realizar o planejamento de ações especificas".

Sabe-se que os acidentes ocorridos no trânsito nunca deixarão de existir completamente, contudo ações conjuntas de engenharia, educação e esforço contribuiriam para a redução de suas probabilidades de ocorrências e para a minimização da severidade quando ocorrer o evento.

ZANOTELLI e COUTINHO (2003), esclarecem que a representação espacial propicia uma leitura sintética e analítica do fenômeno e, por meio de associação e comparação entre os diversos lugares, em diferentes momentos, há possibilidade de compreender as causas da diferenciação tempo-espacial dos eventos. Neste caso, dos acidentes de trânsito e suas circunstâncias. 
Contudo, mais importante que localizar e espacializar o fenômeno, é analisá-lo e compreendê-lo, utilizando-se técnicas e métodos que sejam capazes de identificar as variáveis, assim como localizar, especificadamente, os acidentes de trânsito.

Como contribuição à sociedade, acrescenta os dados informacionais para a cidade de Uberlândia e de cunho pragmático, os locais que mais necessitam de tratamento específico, no que se refere ao sistema viário urbano, ou seja, as vias, os trechos e os identificados com situação crítica. No quadro 52 e mapa 53 , identificam e visualizam a distribuição dos segmentos e pontos na malha urbana da cidade de Uberlândia. 


\section{CONSIDERAÇÕES FINAIS}

Em qualquer temática, as informações de cunho básico obtidas, determinam as tomadas de decisão e o direcionamento dos projetos elementares em planos constituintes para o futuro, seja social, econômico, cultural ou ambiental.

Uberlândia, dinâmica com sua nuance sócio-urbana, tornou interessante o seu estudo, uma vez que, observada a evolução referente a constituições e implementações dos planos urbanísticos, chamou a atenção, quando reconhecidos os números da sua frota efetiva, bem como do índice de motorização declarados. Ressalta-se, ainda, a taxa de migração que absorve, cujos números são altos.

De "cidade jardim", Uberlândia passa a fazer parte do rol das cidades com vários problemas urbanos, em que o processo de urbanização, manifesta-se como uma questão a partir das ações que decorrem das conseqüências vinculadas ao processo de imigração. É a falta de comprometimento e senso de coletividade, assumidas, quando a competição impera entre os cidadãos e os imigrantes, além da vida moderna que instaura o aumento das exigências de mercado, da velocidade da produção de conhecimento ou mercadorias, não obstante, o tempo para a realização das atividades permanece o mesmo.

Isto faz com que todos tenham muita pressa e, assim, reduzam as atenções quando envolvidos no trânsito, aumentando o número de conflitos, que se apresenta, no ano de 2000, 16\% dos acidentes de trânsito/dia, e, em 2004 passa a $21,2 \%$, denotando um aumento de aproximadamente $31 \%$ de acidentes/dia para os anos analisados. 
Foi nesse contexto, tomado como relevante, que foi percebida a necessidade de espacializar os dados e informações que envolvem os eventos sobre os acidentes de trânsito ocorridos em Uberlândia.

As análises realizadas identificaram que, no período de estudo, as características dos acidentes de trânsito ocorridos em Uberlândia, permaneceram as mesmas, tanto para o perfil do condutor como para as condições das vias.

Quanto aos tipos de veículos envolvidos, são os carros que mais se envolvem nos acidentes, com aproximados $60 \%$ do total, sendo, também, expressivos seus números quantitativos. Considerando as condições da via (seca, molhada etc), os acidentes registrados na pista seca superam todas as outras situações, não sendo considerada relevante na análise, pois, as chuvas ocorrem em menos dias que os de sol, não retratando a influência destas condições nas ocorrências.

Os dados demonstraram que o maior número de acidentes está relacionado à questão comportamental dos condutores, pois os cruzamentos das vias possuem sinalizações estratigráficas e semafórica. As causas dos acidentes de trânsito recaem sobre o comportamento do condutor, sendo $60 \%$ delas mais freqüentes, como: não usou freios; mudou subitamente de direção; excesso de velocidade e desobediência à sinalização.

Referente à distribuição temporal, a expressividade dos acidentes de trânsito ocorrem em horários de pico, das $11 \mathrm{~h}$ às $19 \mathrm{~h}$, em vista de um número maior de pessoas e veículos que se deslocam para a mesma área, o centro da cidade. Essa faixa de horas é responsável por quase $60 \%$ dos acidentes de trânsito, sendo aqueles em que ocorrem mortes não concentrar numa faixa horária específica. Os dias de sexta-feira e sábado concorrem para os números de acidentes de maior gravidade, pois o fim de semana propicia diversões variadas que podem levar as pessoas ao uso do álcool, além das ruas estarem mais vazias, no período noturno, o que também pode induzir às velocidades 
acima do permitido. Para os anos de 2000 a 2004, em torno de $16 \%$ e $22 \%$ dos acidentes no trânsito ocorrem nas sextas-feiras e sábados, respectivamente.

Com relação às obras de geometria viária realizadas, assim como, os programas de educação no trânsito, comprova-se o imediatismo que representa a obra em si, ainda que seus efeitos são rápidos, pois, são visíveis e acabam por criar um "símbolo" para a gestão executora. Por outro lado, a educação no trânsito, como qualquer outra, necessita de durabilidade e freqüência, para que tenha seus efeitos positivos. É um processo lento que precisa de investimentos em recursos humanos, que torna um obstáculo aos órgãos gestores quando na manutenção e avaliação dos projetos implantados, sendo que isto não é necessário às intervenções de geometria nas vias.

Salienta-se que as características da infra-estrutura viária não são o fator mais relevante que favorece a ocorrência dos acidentes de trânsito, utilizando o atributo desrespeito às sinalizações do sistema viário, denota-se que o comportamento do condutor exerce influência significativa nos eventos. Os excessos das atividades diárias com a vida moderna fazem com que os motoristas tentem ganhar a diferença do tempo nos deslocamentos, contribuindo, assim, para as causas dos acidentes de trânsito, que confirmam o aspecto comportamento.

A espacialização dos dados torna-se importante, pois, permite observar nos mapas ao longo do estudo, as vias que se repetem, e, assim, identificá-las rapidamente.

A distribuição espacial dos dados, para os anos de 2000 a 2004, apresenta as vias, os trechos e os cruzamentos considerados em situação crítica, sendo eles; Av. João Naves de Ávila e Av. Rondon Pacheco em se tratando das vias; para os trechos, Av. João Naves de Ávila entre R. Luiza de Jesus e Av. Ubiratan Honório de Castro e Av. João Naves entre Av. Cesário Alvim e Av. Floriano Peixoto; e os cruzamentos instituídos como os mais críticos foram, Av. João 
Naves de Ávila com Av. Rondon Pacheco, Av. João Naves de Ávila com Av. Floriano Peixoto e Av. Rondon Pacheco com Av. Nicomedes Alves dos Santos.

Constatou-se que os acidentes de trânsito, geralmente, ocorrem nos mesmos locais, que, assim, permanecem sem grandes alterações, tornando, indistintamente, mais viável o tratamento preventivo do que o posterior, tendo em vista a relação de benefício social que essa decisão apresenta frente aos custos estabelecidos quando as intervenções não ocorrem. Mesmo assim, têm-se os eventos que aleatoriamente se distribuem na malha viária.

Quanto às identificações das vias, dos trechos e dos cruzamentos em situações consideradas críticas, estas tem como finalidade subsidiar o poder público no que se refere às intervenções executadas e por realizar, utilizando os dados seqüenciais dos anos analisados, de 2000 a 2004, assim como, abrir oportunidade, de continuar as análises, a fim de obter maiores detalhes sobre cada um dos segmentos ou cruzamentos.

Salienta-se o peso das informações que um sistema nacional de banco de dados único disponibilizaria aos setores responsáveis pelas estatísticas dos acidentes de trânsito, que seriam mais completas e favoreceriam aos órgãos institucionais e a sociedade. Em duas bases de dados comparadas, para os números de óbitos em acidentes no trânsito, ocorridos em Uberlândia, encontrouse uma diferença nos números absolutos dos B.O. da SETTRAN e Polícia Militar como os do DATASUS, de 91 óbitos no ano de 2002, 89 no de 2004, 86 no ano de 2003, 72 para o de 2001 e 34 para o ano de 2000.

A intervenção nas vias por meio da fiscalização eletrônica, realizada em meados do ano de 2000, repercutiu na queda do número de ocorrências quando analisadas a severidade feridos leves e graves, principalmente. Estes equipamentos estabelecem limites que são cumpridos pelos condutores, tendo em vista a conseqüência dos custos pelas multas. 
Assim, a gestão pública enfrenta grandes desafios, que já são conhecidos, como: oferecer, com qualidade e eficiência aos contingentes populacionais, garantia de segurança durante os seus deslocamentos, ainda que o aumento da frota de automóveis e do seu uso indiscriminado tenda a agravar os problemas de congestionamento, poluição e acidentes nas áreas urbanas.

Mesmo que planos e projetos desencadeiem ações advindas do poder público, é relevante que o órgão responsável pelo planejamento urbano esteja sempre vinculado às atividades por ele ramificadas, em que esse instrumento de análise seja útil como suporte às empresas e instituições.

Portanto, estudos desta natureza, qual seja a espacialização de informações geográficas, oferece, significativamente, a oportunidade para detalhar cada um dos pontos críticos identificados, bem como seu entorno, por vezes, reconhecidos pelos trechos ou pelas vias, que podem apresentar, também, os locais de maior atratividade de pessoas e veículos. Isto indicará com mais confiabilidade o local para a intervenção, assim como, seus impactos advindos desta, e, em seguida as definições das ações pertinentes à questão.

Em se tratando de estudos sobre a temática do trânsito urbano, sabe-se que esta possui muitas variáveis de diferentes desdobramentos que são de grande importância, ainda que, também, multidisciplinares, os quais abrem caminhos vastos para a continuidade este estudo. 


\section{REFERÊNCIAS}

ANDRADE, T.A. et al. Fluxos migratórios nas cidades médias e regiões metropolitanas brasileiras: a experiência do período 1980/96. Rio de Janeiro, julho de 2000. Disponivel em: http://www.ipea.gov.br/pub/td/tda2000b.html\#747. Acesso em: 13/12/2005.

ANFAVEA (Associação Nacional dos Fabricantes de Veículos Automotores). Anuário Estatístico da Indústria Automobilística Brasileira, 2003. Disponível em: http://www.anfavea.com.br/Anuario2003/Cap2_01.pdf. Acesso em: 19/10/2003.

ANTP (Associação Nacional de Transportes Públicos). Política Nacional de Trânsito (versão para debate), [2003?]. Disponível em: http://www.antp.org.br/telas/noticias_uitp2.htm. Acesso em: 19/03/2005.

AZEVEDO, H.P.L. Estudo de desempenho dos espaços públicos para o pedestre: um estudo de caso no centro de Taguatinga. Brasília: UNB, 1992. (Dissertação, Mestrado).

BRASIL. Código Nacional de Trânsito. Lei 9503, Institui o Código de Trânsito Brasileiro. Brasília: Presidência da República , 23 set. 1997.

- Ministério dos Transportes. Programa PARE: procedimentos para o tratamento de locais críticos de acidentes de trânsito. Brasília: CEFTRU/UnB, 2002. 74p.

. Ministério das Cidades. Política Nacional de Trânsito (PNT). Brasília: DENATRAN, set. 2004 (Relatório)

CARRETA atropela carrinho de bebê e mata criança. CORREIO. Uberlândia 4 de abril de 2003. Segurança, p.B4.

CARVALHO NETO, J.A. Aspectos epidemiológicos dos acidentes de trânsito em Brasília, Distrito Federal, no período de 1980 a 1994. Brasília: UNB, 1996 (Dissertação, Mestrado). 
COMISSÃO de Circulação e Urbanismo da ANTP. Não-transporte, a Reconquista do Espaço e do Tempo Social. Revista dos Transportes Públicos. ANTP, n.44. São Paulo, 1989.

CONCHA-EASTMAN, A.; ACERO-VELÁSQUEZ, H. A segurança no trânsito: um problema de política pública "políticas públicas para melhorar a segurança do trânsito. In: Acidentes de trânsito em Uberlândia: ensaios de epidemiologia e da geografia. Uberlândia: Aline, 2006. p.177-216.

CORRÊA, R.L. O espaço urbano. São Paulo: Ática, 1989.

MUNDIM, P. Imigração leva Prefeitura a aumentar o orçamento. CORREIO. Uberlândia, 13 de novembro de 2005. Cidade, p.B8.

DATASUS. Departamento de Informações do Sistema Único de Saúde. Informações de Saúde. Rio de Janeiro. Disponível em: http://tabnet.datasus.gov.br/cgi/deftohtm.exe?sim/cnv/obtMG.def. Acesso em: 08/08/2006.

DENATRAN (Departamento Nacional de Trânsito). Frota de veículos, por tipo e com placa, segundo as Grandes Regiões e Unidades da Federação - Dez. de 2005. Disponível em: http://www.denatran.gov.br/Frota_03.htm.Acesso em: $13 / 12 / 2005$.

Frota de veículos, por tipo e com placa, segundo os Municípios da Federação - Dez. de 2005a. Disponível em: http://www.denatran.gov.br/Frota_03.htm.Acesso em: 19/01/2006.

Frota de veículos, por tipo e com placa, segundo os Municípios da Federação - Dez. de 2002 a 2005. Disponível em: http://www.denatran.gov.br/Frota_03.htm.Acesso em: 19/01/2006.

Frota de veículos, por tipo e com placa, segundo as Grandes Regiões e Unidades da Federação - Jun. de 2006. Disponível em: http://www.denatran.gov.br/Frota_03.htm.Acesso em: 1/11/2006.

Instrução Básica de Estatística de Trânsito - 2006a. Disponível em: http://www.denatran.gov.br/Instrucao\%20Basica\%20de\%20Estatistica $\% 20 \mathrm{de} \% 20$ Trânsito/index.htm Acesso em: 19/01/2006. 
Total de condutores, 2003. Disponível em:

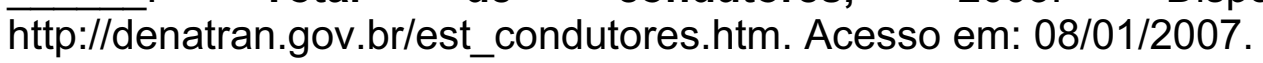

DESLANDES, S.F.; UGÁ, C.M.F.P.; DOMINGUEZ, M.A. O custo do atendimento emergencial às vítimas de violência em dois hospitais do Rio de Janeiro. In: Cadernos de Saúde Pública, 14(2):1-19. Rio de Janeiro, 1998.

FANTÁSTICO/Rede Globo de Televisão. [Reportagem sobre pesquisa de acidentes de trânsito realizada pela OMS]. Rio de Janeiro:16 maio 2004 (mídia televisiva).

FELGUEIRAS, C.A. Metodologias de integração de dados em SIG's. In: Simpósio Brasileiro de Geoprocessamento, 1, Manaus, 1990. Anais... Manaus, [s.n], 1990.

FELIX, A.F. Geografia do Crime de Marília/SP: aspectos da violência e criminalidade em uma cidade média brasileira. Seminário Internacional de Estudos Urbanos, 4., 2003. Buenos Aires. Resumos... Buenos Aires, 2003. CDROM.

FERREIRA, D.L. Sistema de Informação Geográfica e planejamento de transporte coletivo urbano. Estudo de caso: Sistema Integrado de Transporte de Uberlândia. São Paulo: USP, 2000. (Tese, Doutorado).

FERREIRA, I.C.B.; PENNA, N.A. Território da violência. In: PAVIANNI, A., FERREIRA, I.C.B., BARRETO, F.F.P. (orgs.) Brasília: dimensões da violência urbana. Brasília: Editora Universidade de Brasília, 2005.p.57-86.

FERREIRA, W.R. Áreas centrais congestionadas: a questão dos pedestres um estudo de caso. Brasília: UNB, 1997. (Dissertação, Mestrado).

O espaço público nas áreas centrais: a rua como referência - um estudo de caso em Uberlândia (MG). São Paulo: USP, 2002. (Tese, Doutorado).

Folha de São Paulo. Mortes no trânsito. São Paulo, 19 de abr. 2004. Disponível em: http://www.folha.com.br. Acesso em: 20/04/2004 
FRANCISCO FILHO, L.L. Distribuição espacial da violência em Campinas: uma análise por geoprocessamento. Rio de Janeiro: UFRJ, 2004. 170 p. (Tese, Doutorado).

FREITAS, Clayton A. D. Padrão de urbanização e uso do solo urbano - O caso de Uberlândia. Uberlândia: UFU, 1989. (Monografia, Bacharelado).

GEIPOT (Empresa Brasileira de Planejamento de Transportes). Anuário Estatístico dos Transportes, 2001. Disponível em: http://www.geipot.gov.br/anuario2001/rodoviario/tabelas577.xls. Acesso em: 13/12/2005.

GERARDI, L.H. de O.; SILVA, B-C. M. N. Quantificação em Geografia. São Paulo: DIFEL, 1981. p.137-148.

GOLD, P. A. Segurança de trânsito - aplicações de engenharia para reduzir acidentes. Washington (EUA): Banco Interamericano de Desenvolvimento: 1998. $211 \mathrm{p}$.

HIDROSERVICE ENGENHARIA DE PROJETOS LTDA. Assessoria técnica na implantação de transporte coletivo e plano cicloviário. Uberlândia: Hidroservice, 1980.

HOUAISS, A. ; VILLAR, M. S. Dicionário Houaiss da Língua Portuguesa. Rio de Janeiro: Objetiva, 2001.

HUTCHINSON, B. G. Princípios de planejamento dos sistemas de transporte urbano. Rio de Janeiro: Guanabara dois, 1979.

IBGE (INSTITUTO BRASILEIRO DE GEOGRAFIA E ESTATÍSTICA). Censo demográfico, 2000. Disponível em: http://www.ibge.gov.br/home/estatistica/populacao/censo2000/tabelagrandes_regi oes211.shtm. Acesso em: 13/12/2005

População Estimada 2006. Disponível em:

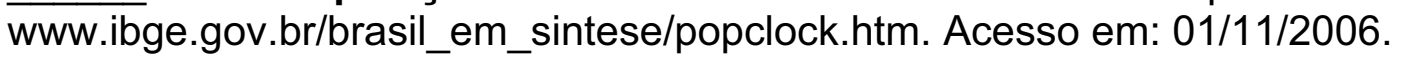


IPEA (INSTITUTO DE PESQUISA ECONÔMICA APLICADA). Para a década de 90. Brasília, v.3, 1990. (Coletânea)

. População brasileira. [2001] Disponível em: www.ipeadata.gov.br Acesso em: 05/10/2005.

IPEA/ANTP. Impactos sociais e econômicos dos acidentes de trânsito nas aglomerações urbanas brasileiras. Relatório executivo. Brasília: IPEA/ANTP, 2003. (CD-ROM).

JUNQUEIRA, C.B. GEOPROCESSAMENTO ON LINE, 1998. Disponível em: http://143.107.240.36/index.htm. Acesso em 26/12/2006.

JUNQUEIRA, E. Cidades - a boa vida no interior. VEJA, São Paulo, ano 31, n.10, 11.3.2000, p. 70-6.

A circulação de pedestres. In: Revista dos Transportes Públicos/ANTP. São Paulo, ano 25, n.100, 2003. p.159-166.

MENINA atropelada passa bem. CORREIO. Uberlândia, 9 de abril de 2003. Segurança, B4.

MARLET, J.M. Vitimologia e Violência Urbana. In: Revista IMESC. São Paulo: Instituto de Medicina Social e de Criminologia de São Paulo, n.1: dez.1998. Disponível em: http:www.imesc.com.br. Acesso em: 22/03/2004.

MEIRELES, A.C. Dados de acidentes de trânsito ou dados de conflito de tráfego? Uma análise sobre sua aplicabilidade nos estudos de segurança viária. Costa Rica, Anais...,1992.

MENEZES, H.R. Brasil: transporte para o futuro - transporte urbano. Brasília: CNT/GEIPOT, 1992.

MESQUITA, A. P. Influência dos conflitos de interesse na não implementação dos programas de ação imediata em trânsito e transportes: análise de caso - programa para Uberlândia. Uberlândia: UFU, 1992. (Monografia, Bacharelado). 
- Características físico-operacionais de cruzamentos urbanos e ocorrências de acidentes. Brasília: UnB, 1995. (Dissertação, Mestrado).

MELLO JORGE, M.H.; KOIZUMI, M.S. Panorama dos Acidentes de Trânsito/Transportes no Brasil. Acidentes de trânsito em Uberlândia: ensaios de epidemiologia e geografia. Uberlândia: Aline, 2006. p.11-39.

MGTV/Rede Globo de Televisão. [Reportagem sobre os acidentes de trânsito]. Uberlândia, 12 abr. 2004 (mídia televisiva).

MORAIS, R. O que é violência urbana. São Paulo: Brasiliense, 1990. 113p.

NETO, J. S.; EDWARD, J. Vida brasileira - Brasil que agüenta o tranco - a civilização criada longe dos grandes centros é rica e orgulhosa de seus valores. VEJA. São Paulo, ano 32, n. 20, 19.5.1999, p. 122-133.

OLIVEIRA, D. R. de. Sistemas de informações gerenciais: estratégicas, táticas, operacionais. São Paulo: ATLAS, 1993.

OLIVEIRA, V. Dói no bolso, mas ajuda a salvar vidas. Livre Mercado: grande ABC. (134)XII, p.20-25, maio, 2001.

OPAS (Organização Pan-Americana da Saúde). Segurança no trânsito: um problema de política pública. Washington, DC, 2004 (mimeo.)

PIETRANTONIO, H.; ROZESTRATEN, R.J.A. Psicologia e engenharia no trânsito: uma agenda para ação conjunta em pesquisa aplicada. ANPET, Anais...1992.

PONTES, B.M.S. Estratégia territorial proposta pelo programa das cidades médias do Estado de São Paulo: reflexão crítica. Rio Claro: Câmara Municipal/AGB, 1985.

PREFEITURA MUNICIPAL DE UBERLÂNDIA. Plano de Urbanização da Cidade de Uberlândia. Uberlândia: [s.n.], 1954. 
REVISTA TUDO. Trabalho - 20 cidades com ótimas vagas. São Paulo, 04.03.2001. p.31-33.

REVISTA EXAME. Temperatura máxima. São Paulo, p. 140/165, 22 nov.1998.

RIBEIRO, S.L.F. Formas de se reduzir a necessidade de transporte urbano motorizado. Brasília: UNB, 1993 (Dissertação, Mestrado)

RODRIGUES, M. Geoprocessamento. São Paulo: Escola Politécnica da Universidade de São Paulo, 1989. (Tese, Doutorado).

ROCHA FILHO, G.N.da (trad.). Carta dos Andes. São Paulo: Bem Estar, 1960.

ROSA, R. e BRITO, J. L. S. Introdução ao Geoprocessamento: sistema de Informação Geográfica. Uberlândia: Edufu, 1996.

ROSA, R. et al. Mapeamento de homicídios em Uberlândia/MG entre 1999 e 2002, utilizando o software ArcView. Caminhos de Geografia, Uberlândia, v.3, n.14, p.27-45, fev,2005. Artigo disponível em http://www.ig.ufu.br.html. Acesso em: 17 de julho de 2005.

RESENDE, V. Planejamento urbano e ideologia. Rio de Janeiro: Civilização, 1982.

SANTOS, M. A urbanização brasileira. São Paulo: HUCITEC, 1993.

SANTOS, S.M. Homicídios em Porto Alegre, 1996: análise ecológic de sua distribuição e contexto socioespacial. Rio de Janeiro: Escola Nacional de Saúde Pública/Fundação Osvaldo Cruz, 1999. 126p. (Dissertação, Mestrado).

SETTRAN. Sistema de Informações Gerenciais de Acidentes de Trânsito/SIGAT. Uberlândia: VERTRAN, 2000. (arquivo eletrônico).

Sistema de Informações Gerenciais de Acidentes de Trânsito/SIGAT. Uberlândia: VERTRAN, 2001. (arquivo eletrônico). 
.. Sistema de Informações Gerenciais de Acidentes de Trânsito/SIGAT. Uberlândia: VERTRAN, 2002. (arquivo eletrônico).

Sistema de Informações Gerenciais de Acidentes de Trânsito/SIGAT. Uberlândia: VERTRAN, 2003. (arquivo eletrônico).

Sistema de Informações Gerenciais de Acidentes de Trânsito/SIGAT. Uberlândia: VERTRAN, 2004. (arquivo eletrônico).

SILVA, A.M.; PINHEIRO, M.S.de F.; FRANÇA, M.N. Guia para normalização de trabalhos técnico-científicos: projetos de pesquisa, trabalhos acadêmicos, dissertações e teses. 5. ed. Uberlândia: UFU, 2006. 145p.

SILVA, C.R.L da. \& KILSZTAJN, S. Acidentes de trânsito, frota de veículos e nível de atividade econômica. In: Revista de Economia Contemporânea. Rio de Janeiro, 7(1):147-159, jan./jun.2003. Disponível em: http:www.ie.ufrj.Br/revista/lng/pt/artigos_publicados.php. Acesso em: 13/12/2005.

SILVA, S. Falha humana responde por $90 \%$ dos acidentes. CORREIO. Uberlândia, 6 maio 2004. Cidades, B3.

SILVEIRA, J. Aspectos epidemiológicos de vítimas dos acidentes de trânsito em Uberlândia - 2000. Uberlândia: UFU, 2002. (Dissertação, Mestrado)

SILVEIRA, J. e RIBEIRO, L.A. Assistência Hospitalar à Vítima de Acidente de Trânsito. Acidentes de trânsito em Uberlândia: ensaios de epidemiologia e geografia.Uberlândia: Aline, 2006. p.79-88.

SOARES, B. R. Repensando as cidades médias brasileiras no contexto da globalização. Formação. Presidente Prudente, n.6, p. 55-66, 1999.

SOUZA, M. L. de . Uma crise e o seu "day after": a situação dos movimentos sociais urbanos. In: SOUZA, M. L. de. O desafio metropolitano: um estudo sobre a problemática sócio-espacial nas metrópoles brasileiras. Rio de Janeiro: Bertrand Brasil, 2000. p. 141-178. 
SPÓSITO. E. S. A vida nas cidades. São Paulo: Contexto, 1994.

TEIXEIRA, Amandio L. A.; MORETTI, Edmar.; e CRISTOFOLETTI, Antônio. Introdução aos Sistemas de Informação Geográfica. Rio Claro: [s.n.], 1992.

UBERLÂNDIA. Plano de Trânsito. Uberlândia: Prefeitura Municipal de Uberlândia, fev.1991.

Lei Orgânica do Município de Uberlândia-MG. Uberlândia: Prefeitura Municipal de Uberlândia/Câmara Municipal dos Vereadores,1990.

. Lei n. 5.013 de 01 de dezembro de 1989 - Dispõe sobre o uso e a ocupação do solo na cidade de Uberlândia. Uberlândia: Prefeitura Municipal de Uberlândia/Câmara Municipal de Vereadores, 1989.

Lei complementar n. 432 de 19 de outubro de 2006 - Princípios básicos e as diretrizes para implantação do Plano Diretor. Revoga a lei complementar n.078 de 27 de abril de 1994. Uberlândia: Prefeitura Municipal de Uberlândia/Diário Oficial do Município, Ano XVIII n.2541-A de 23 out. 2006.

VASCONCELLOS. E. A. de. A cidade, o transporte e o trânsito. São Paulo: Prolivros, 2005.

Transporte urbano, espaço e equidade: análise das políticas públicas. São Paulo: Unidas, 1998.

Transporte urbano nos paises em desenvolvimento: reflexões e propostas. São Paulo: Unidas, 1996

VILELA, L. de O. Duas temáticas em um mesmo setor: Controle de Tráfego em Área e levantamento de estatísticas de acidentes de trânsito em Uberlândia - MG. Uberlândia: Universidade Federal de Uberlândia, 2005. (Relatório de Estágio Supervisionado).

VILLELA, P. de A. A educação para o trânsito como estratégia para uma nova mobilidade urbana. Uberlândia: Universidade Federal de Uberlândia, 2006. (Dissertação, Mestrado). 
VIOLÊNCIA Urbana e Concentração de Renda Crescem no Brasil. CORREIO. Uberlândia, 14 de maio 2004. Cidade, B3.

WRIGHT, C.L. O que é transporte urbano. São Paulo: brasiliense, 1988.

ZANOTELLI, C.L.; COUTINHO, L.A. Atlas da criminalidade violenta da Grande Vitória: 1993-2002. Estratégias e desafios: violência, direitos humanos e segurança pública. Vitória(ES): Núcleo de estudos sobre violência, segurança pública e direitos humanos, 2003. p.212-237. 


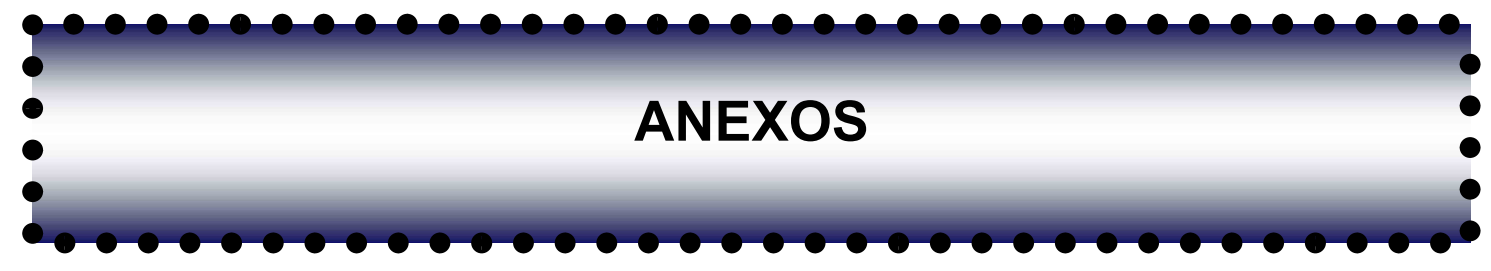




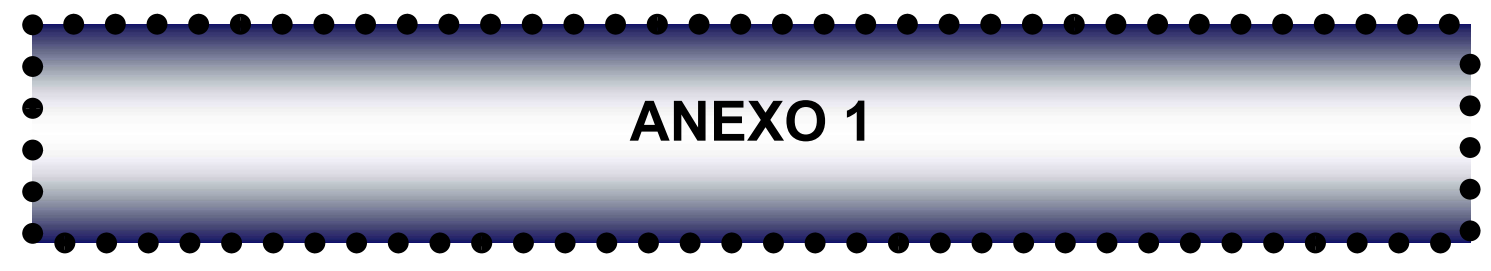


PLANILHA LEVANTAMENTO DE ACIDENTES5

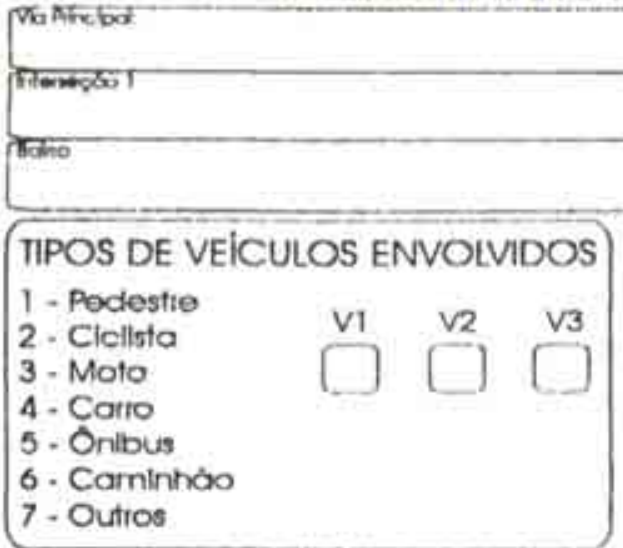
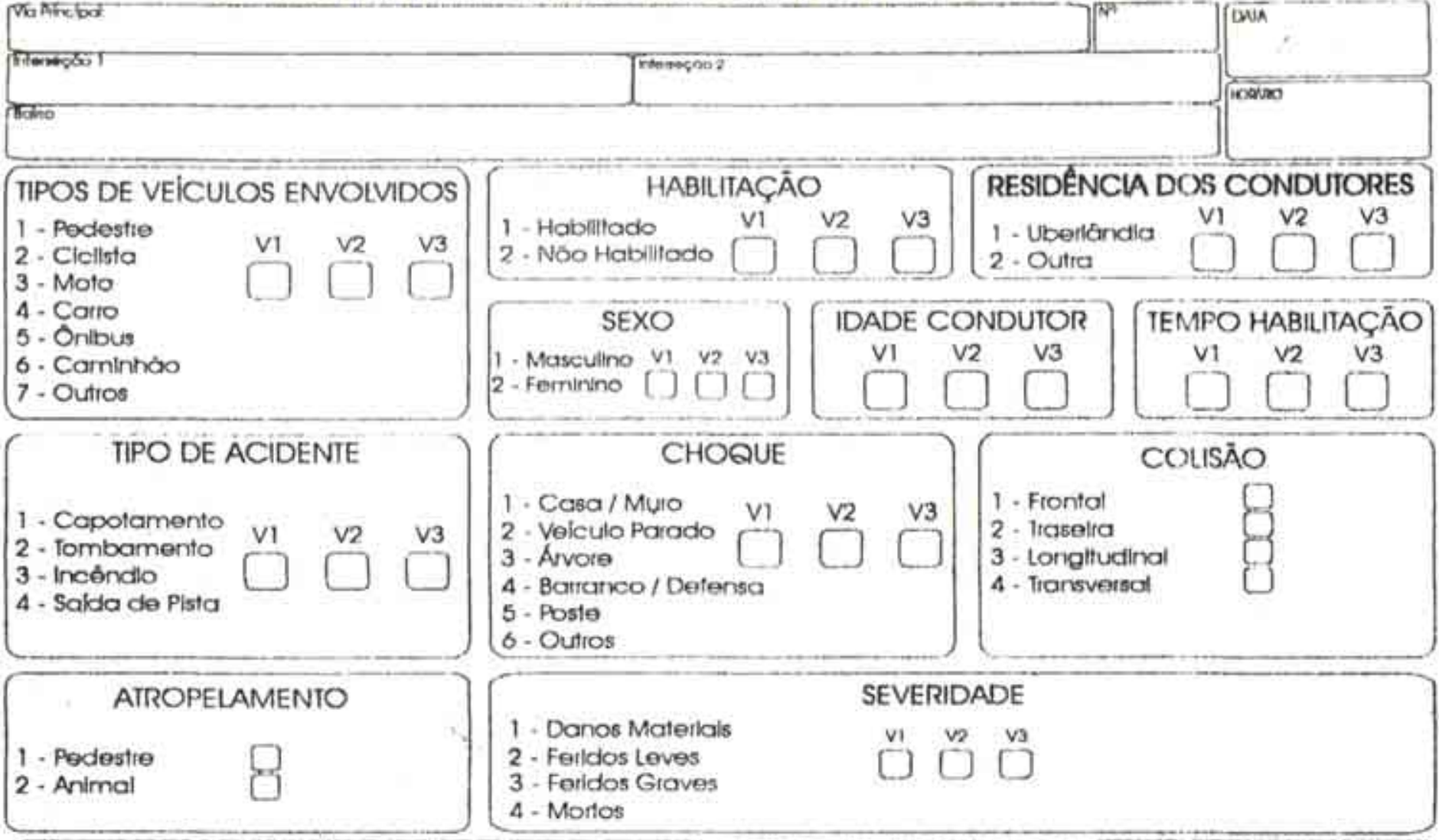

1. Danos Materlals
2. Feridos Leves

CAUSAS PRESUMIVEIS DO ACIDENTE

1. Avançou o sinal

2. Contra a máo de dilıę̧ão

3 - Delxou de fazet sinal

4. Desobedeceu sinal de "PARE"

5 - Excesso de velocidade

6. - Mudo subltamente de direçä́o

7. NĆO usou frelos

8 - Parado na plsta

9. Parou subltamente

10 - Ultrapassou em cruzamento

11 - Delelto nos frolos

12 - Pedestre ao longo da pista

13- Outros

\begin{tabular}{|c|c|}
\hline CONDIÇOES PRESUMIVEIS & DOS COND. \\
\hline 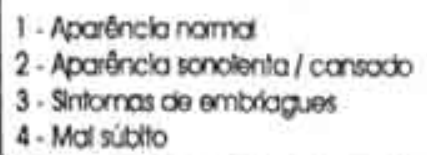 & $\begin{array}{l}000 \\
000 \\
000\end{array}$ \\
\hline
\end{tabular}

COMPORTAMENTO DO CONDUTOR

EM RELAÇAO AO ACIDENIE.

1. Parmaneceu no local

2. Pestou socano a viltra

3. Evoduse do locd

4. Outras

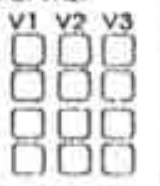

1- TEMPO
2- Nublado
3- Chuvoso
4- Nevoelio
5- Desconhecido

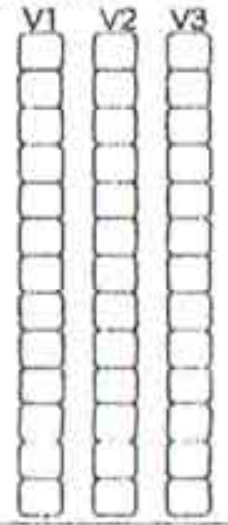

CONDIÇŌES PRESUMÍVEIS DA VIA

CONDIÇŌES GEOMÉTRICAS DA VIA

1. Seca
2. Oleosa
3. Molhada
4. - Lamacenta
5- Butaco / Valeta
6. Obleto na pista
7- Em construçao
8. Em reparos
9. Varlante desvio
10. Acost. ptaticável
11- Acast. impraticóvel

[) 1. Cnzamento

2 - Rela

3- Curva fechada

4- Curva com defelto

5- Passagem de nivel

6. Acllve

7 - Declive

8. Depressoo

9- R. V

10 - Curva

11. Pleta ostrelta

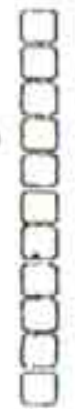

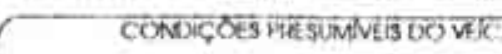

1- viscolve

2. Sem limpoda de para brisa

3. Visoo preludicada por caga

4. Defelto na diegoo

5- Excesso de carga / passogelios

6- Preus deleltuosos

7. Condicles descornecidas

A- Lue deticlente

Q- Outios doleitos

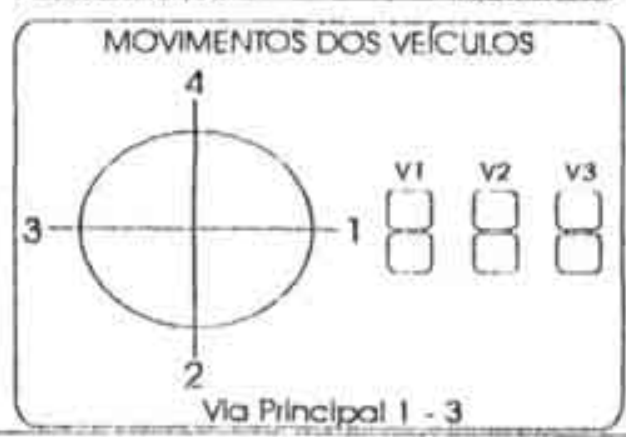

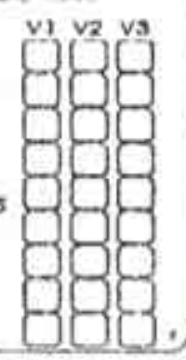

2

2 - Calçamento

3 - Concreto

4 - Terra

5- Outro

1- Escolat
2- Industrial
3- Comercial
4- Residencial
5- Rutal
- Povoado
2- Outto

OBs. 


\section{PLANILHA LEVANTAMENTO DE ACIDENTES DE TRÂNSITO}

Orgă。
PMMG $17^{\circ}$ BPM
PMMG $32^{\circ}$ BPM
Progr. Atendim.Vitima

Ta Principal

rogr. Atendim. Vitims

\section{nterseçio 1} Interseçăo 2

3airro

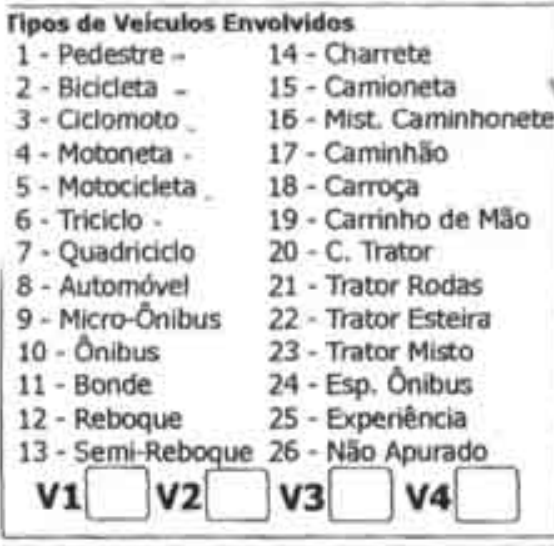

\section{1 - Aparência normal \\ 2- Aparência sonolenta \\ 3 - Sintomas de embriagues \\ 4- Mal súbito \\ 5 - Năo Apurado \\ 6- Outros}

Condiç̧̄es Presumiveis dos Condutores

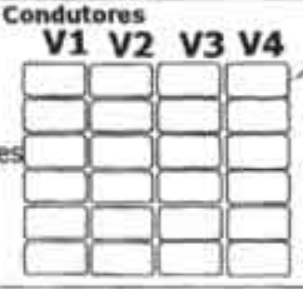

Quantidade

Dados dos Condutores
Habilitaçăo
1 - Habilitado
2- Vencida
3 - Năo Necessita
4 - Não Habilitado
5 - Não Apurado

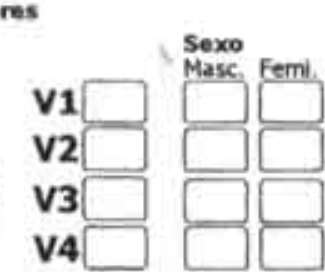

Data Nascimento

Data 1* Habilltaça

\begin{tabular}{|c|c|c|}
\hline Apreensĩo Veículos & Placa Veiculos $\theta$ & Municipio dos Condutores \\
\hline e $\quad \mathbf{v 1} \square$ & & V1 \\
\hline V2 & V2 & V2 \\
\hline v3 & V3 & v3 \\
\hline V4 & $v_{4}$ & v4 \\
\hline
\end{tabular}

Comportamento Condutores em Relaç̄o ao Acidente

1 - Permaneceu no local

2 - Prestou socorro a vitima

3 - Evadiu-se do local

4 - Encaminhado ao Pronto Socorro

5 - Nāo Apurado

6 - Outros.

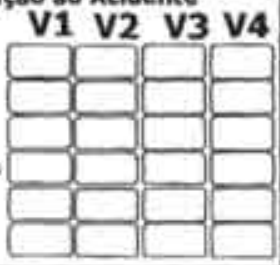

5- Envolvidos

$\begin{array}{llll}V_{1} & V_{2} & V_{3} & V_{4}\end{array}$

\section{Severidade \\ 1 - Sern danos \\ 2. Danos materiais \\ 3 - Feridos leves \\ 4 - Feridos graves \\ 5 - Mortos \\ 6 - Näo apurado}

\section{Atividade Profissional dos Condutores \\ 1-Nenhuma 7-Cargos de chefia \\ 2 - Estudante \\ 3-Aposentado \\ 8 - Profissional liberal \\ 9 - Nầo Apurado \\ 4- Atividades sociais 10 -Outros \\ 5 - Cargos operacionais \\ 6 - Caroos administrativos \\ V1 V2 V3 V4

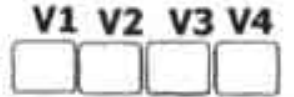

\section{Caracteristicas da Via}

1 - Cruzamento

2. Reta

3- Aclive

4- Decilve

5 - Depressabo

6 - Rotatória

7 - Redutor de velocidade

8 - Curva

9 - Nẵo apurada

10 - Outra

\section{Pavimento do Local}

1 - Asfalto

2-Concreto

3- Terra

4- Cascalho

5 - Paralelepipedo

6- Nẫo apurada

7 - Outros

$\square$

9- Seca

10 - Molhada

12 - Outra

\section{Clima}

1. Bom

2- Chuva

3-Neblina

4- Nublado

\section{Controle de Tráfego \\ 1 - Feito por gesto \\ 2 - Sinal luminoso \\ 3 - Sinaliz. de regulamentaçăo \\ 4 - Sinalização de advertência \\ 5 - Nenhuma sinalização \\ 6 - Desconhecido}

Tipo de Localidade

1 - Escolar

2 - Industrial

3- Comercial

4 - Residencial

5 - Residencial/Comercial

6-Rural

7 - Povoado

8 - Nððo apurada

9-Outra

11 - Năo apurada

5- Nāo apurado

\section{Tipo de Acidente}

1 - Capotamento/tombamento

2 - Abalroamento

3 - Queda de veículo

4 - Queda de pessoa de veiculo

5 - Queda/vazamento de carga

6 - Atropelamento de animal

7 - Choque mecânico

8 - Colisẵo de veículo

9 - Incelndio

10 - Saida de pista

11 - Queda no interior de veículo

12- Atropelamento de pedestre

13- Outros

\section{Causa Presumivel do Acidente}

1 - Animal na Pista

2- Defeito no Veículo

3 - Desobedecer a Sinalizaçăo

4-Desobedecer Sinal de Pare

5 - Excesso de Velocidade

6 - Defeito na Via

7 - Avanço de Sinal Luminoso

8 - N5́o Manteve Distância Segura

9 - Contra - Mão de Direçăo

10 - Ultrapassagem Forçada

11 - Parou Subitamente

12. - Má Visibilidade

13 - Pista Escorregadia

14 - Falta de Atençăo

15 - Pedestre atravessa subitamente

16 - Nào usou os freios

17 - Visāo prejudicada por carga

18 - Mudou Subitamente de direçāo

19 - N3̋̄o apurada

20 - Outros 


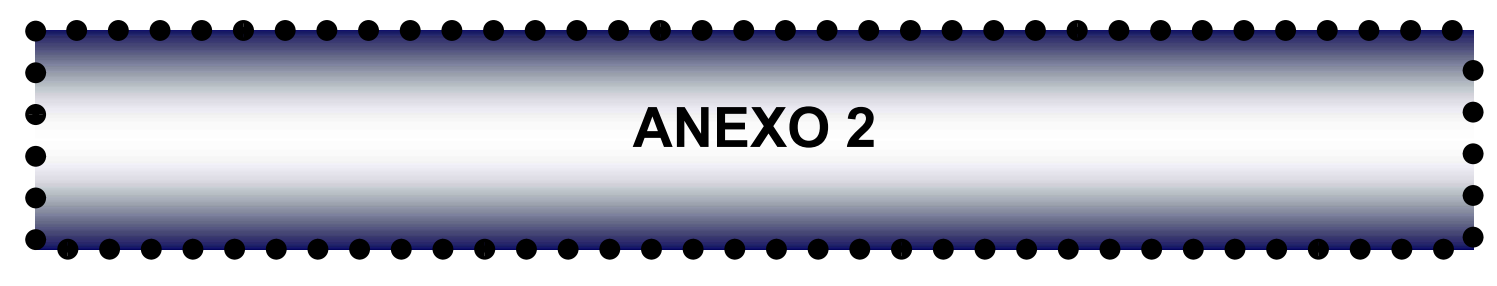


Boletim Municipal de Ocortència No.

$$
5405106
$$

Folna $\frac{03}{26,03}$

IX-ANEXO DESCRITIVO DE ACIDENTE DETRANNSITO

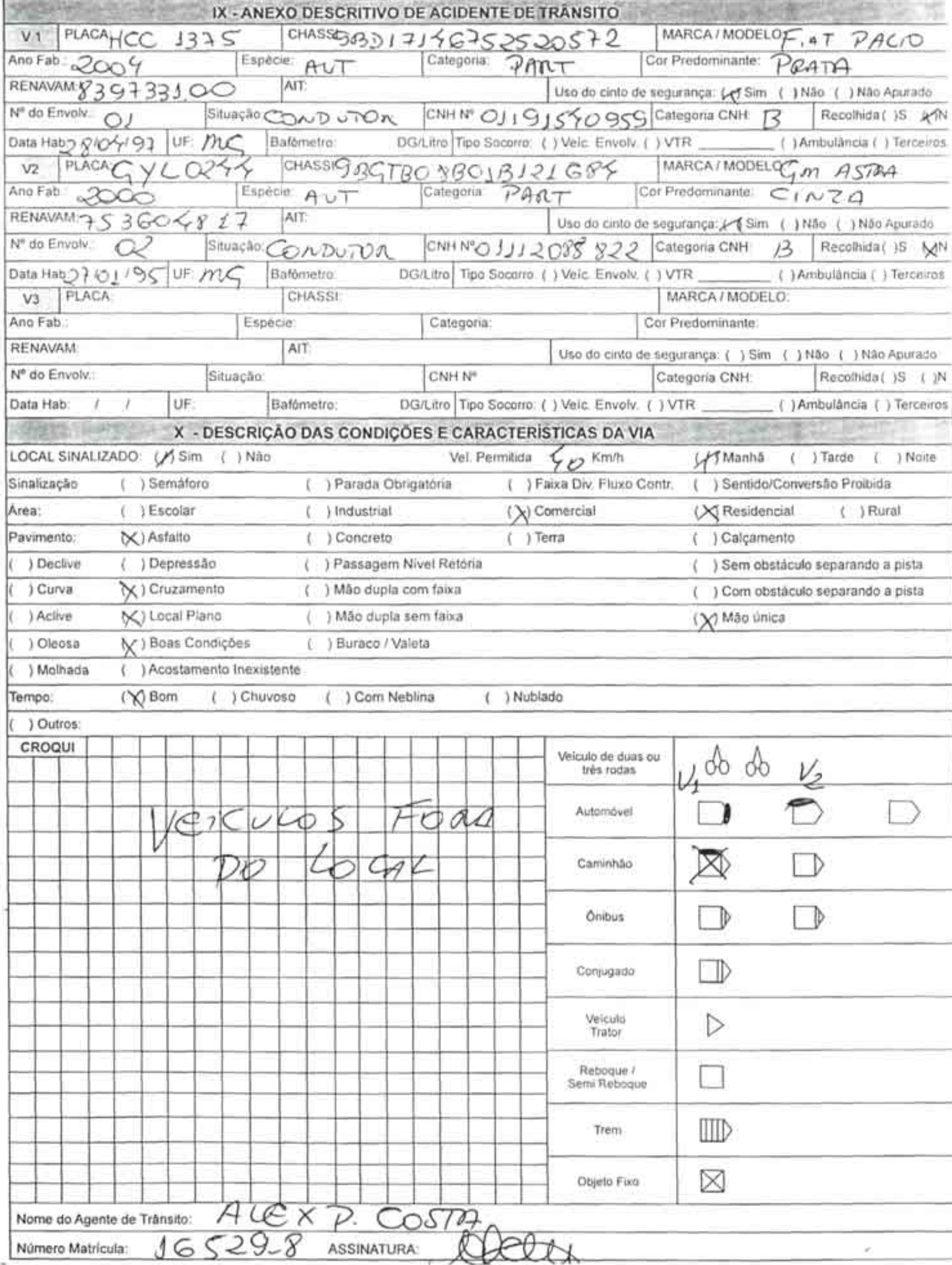




\begin{tabular}{|c|c|c|}
\hline $\begin{array}{l}\text { PREFEITURA } \\
\text { DE UBERLÅNDIA } \\
E \text { UBERLANDI }\end{array}$ & $\begin{array}{l}\text { Boletim Municipai de Ocarência Ne } \\
\qquad 5405 / 06\end{array}$ & Fatha $\frac{02}{26,09}, \frac{03}{0.06}$ \\
\hline
\end{tabular}

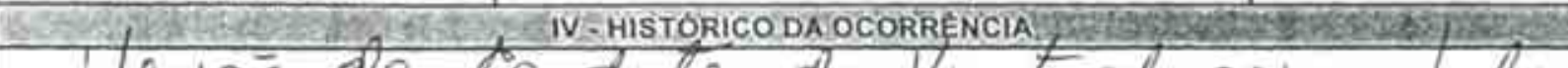

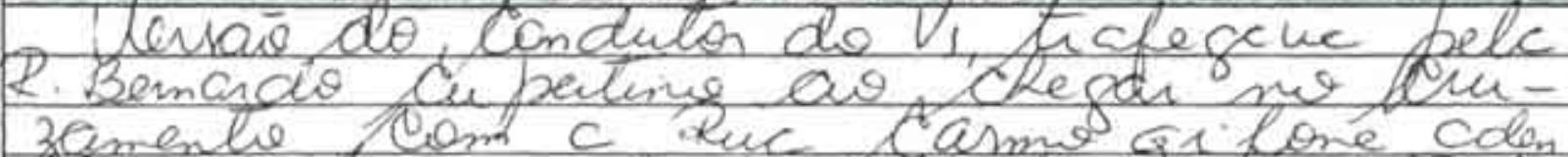

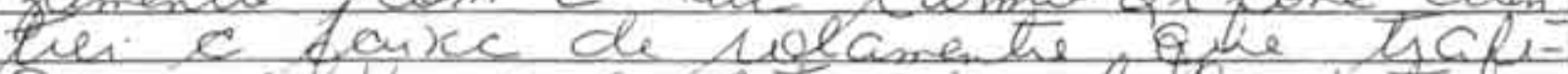

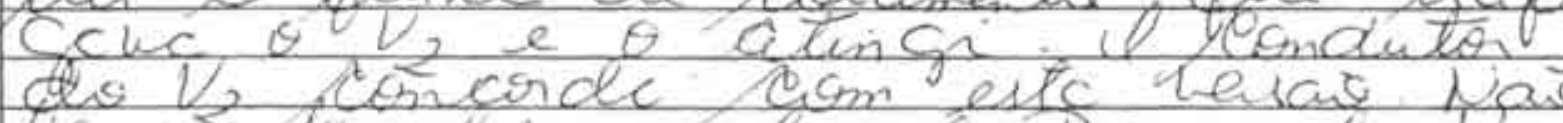

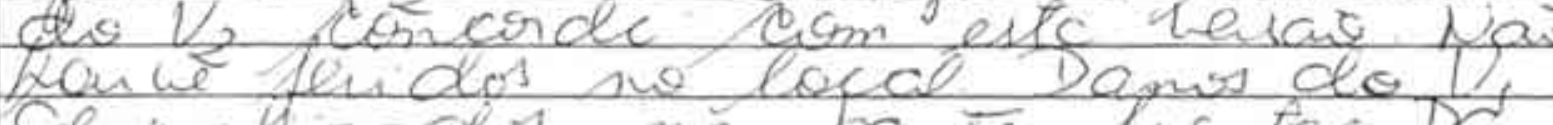

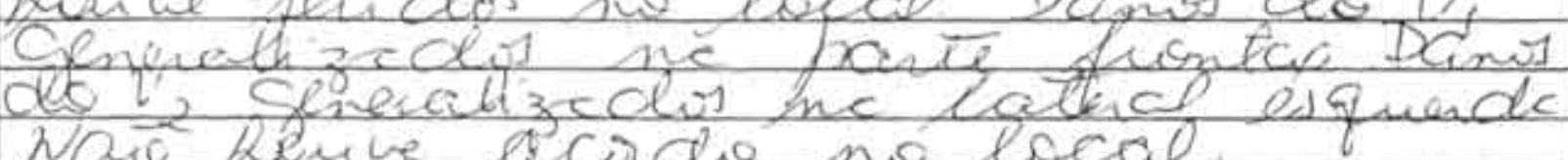
nav perve excolo no lecal.

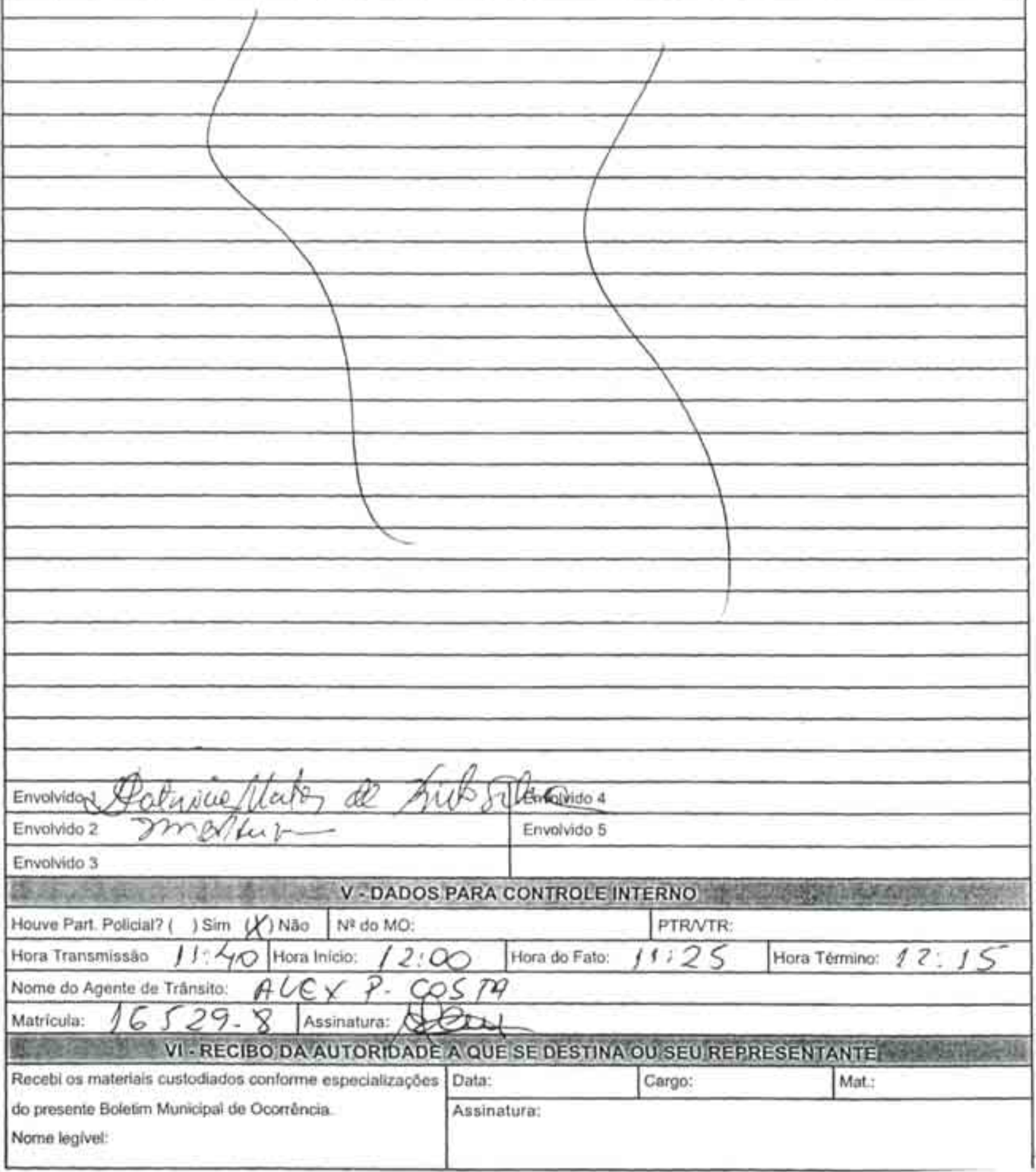




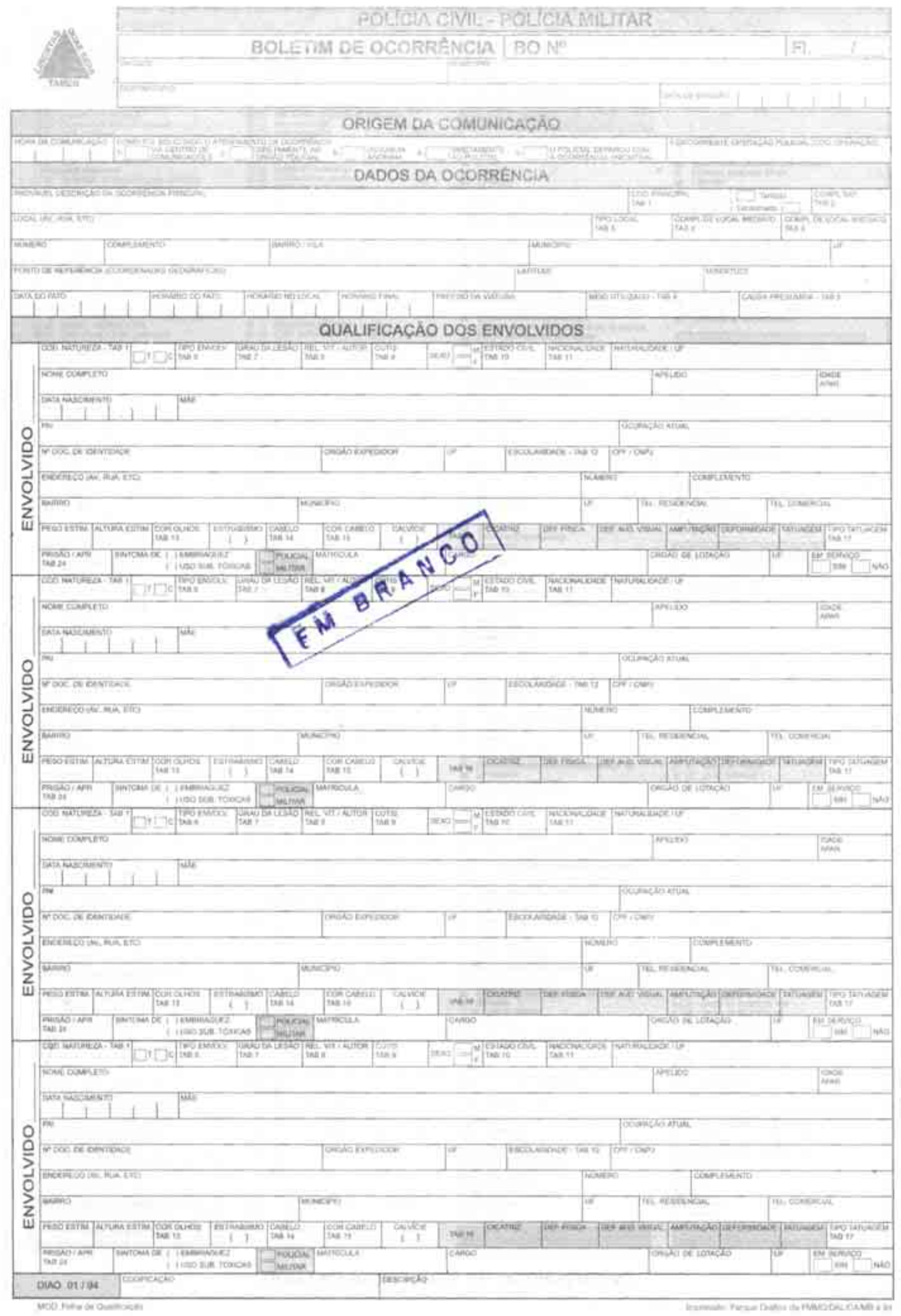



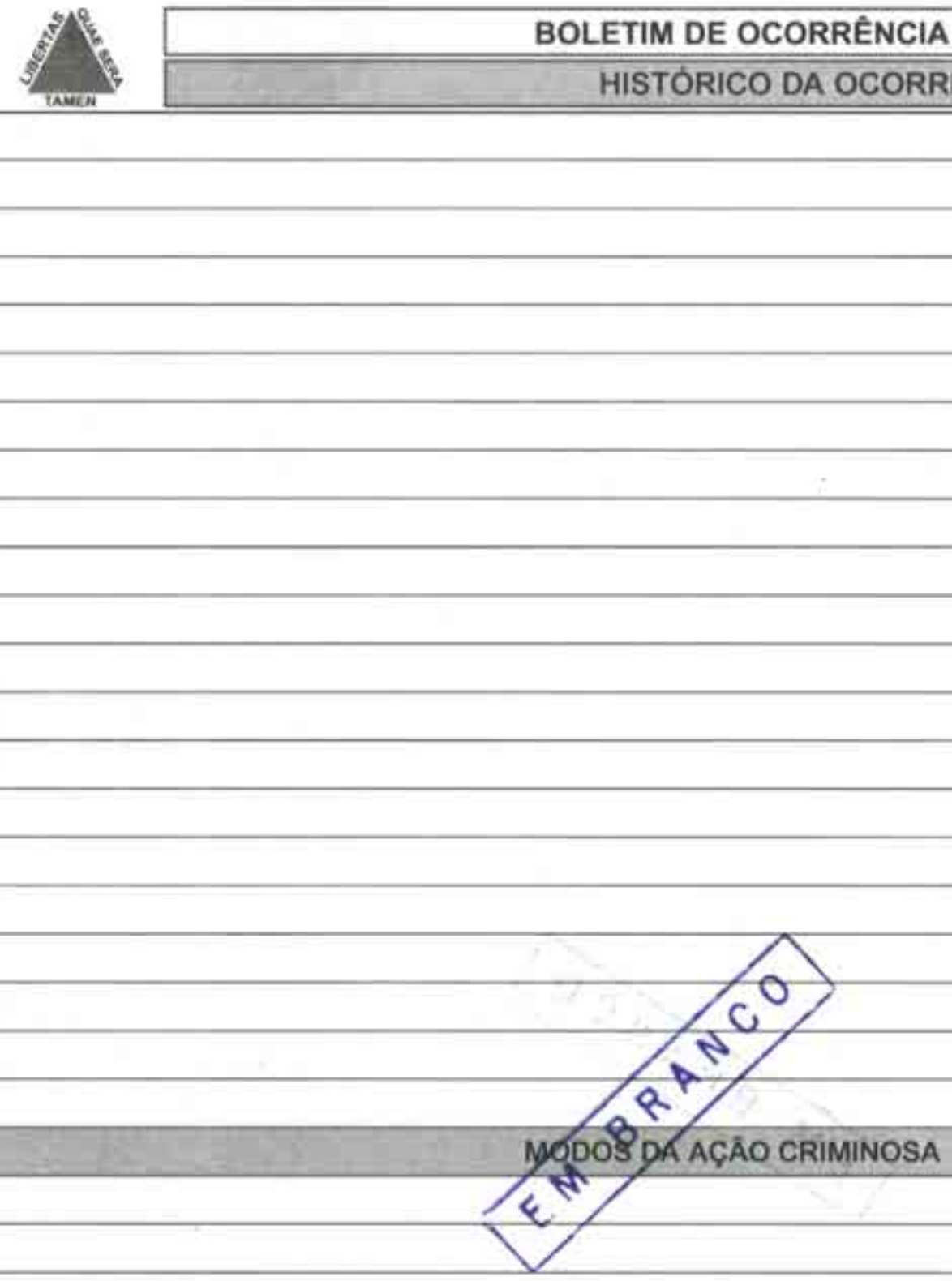

\section{POLICIAIS INTEGRANTES DA GUARNIÇĀO / EQUIPE}

\begin{tabular}{|c|c|}
\hline MATICURA & 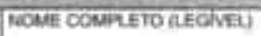 \\
\hline MATricinA & NONE OOWRETO NEOVES \\
\hline Matricinh & 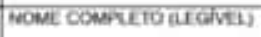 \\
\hline Matricula & 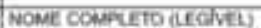 \\
\hline
\end{tabular}

\section{RESPONSÁVEL PELA APREENSÃO / PRISĀO / CONDUÇĀO}

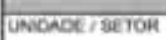

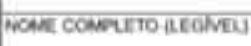

Agsanatuma

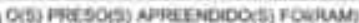

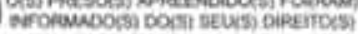
जutrocis

\section{DADOS PARA CONTROLE INTERNO/RELATOR DA OCORRÊNCIA}

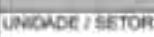

MOMF COSA LTO HEONEY

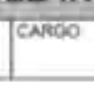

Murisoun

Assinaruen

\section{RECIBO DA AUTORIDADE A QUE SE DESTINA OU SEU AGENTE / AUXILIAR POLICIAL}

Recebi as pessoas a os materiais

contorme especificaçōes contidas na(s)

follha(s)

deste boletim

de ocoméncia

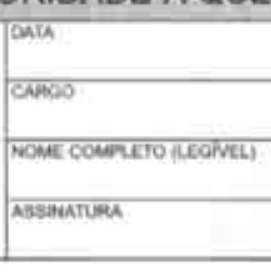

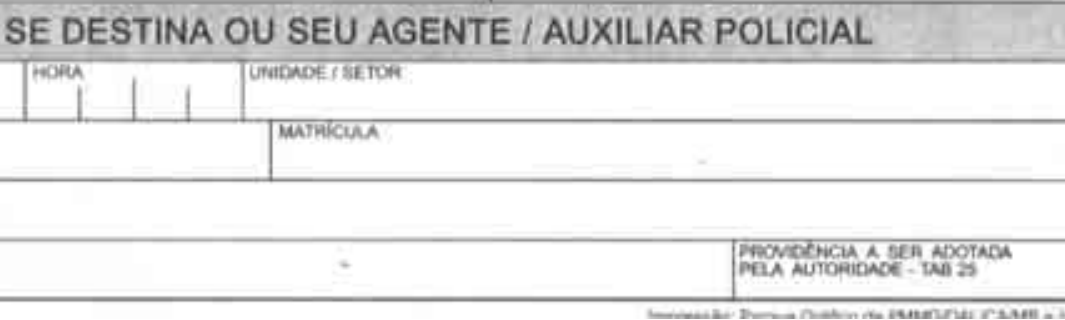




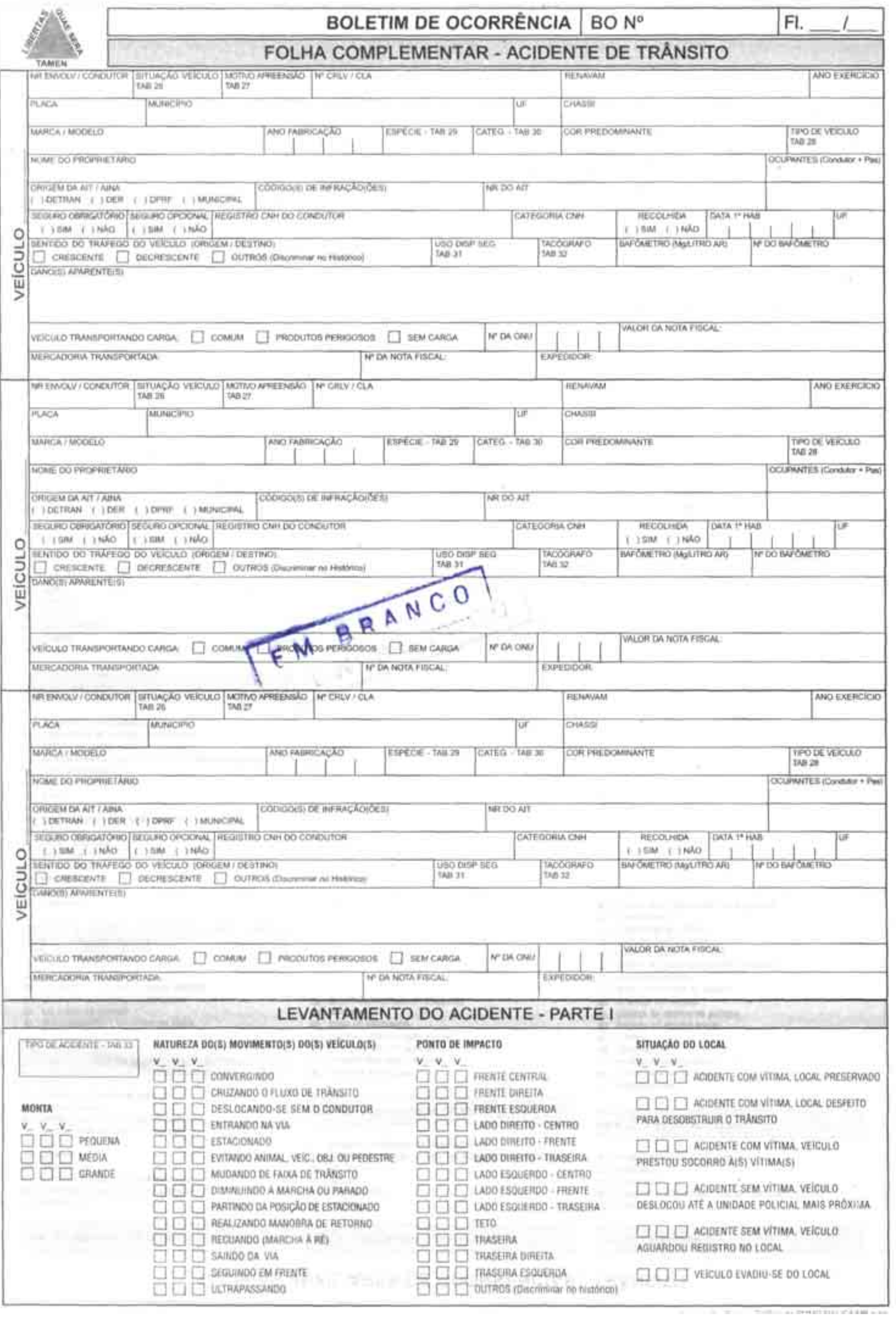




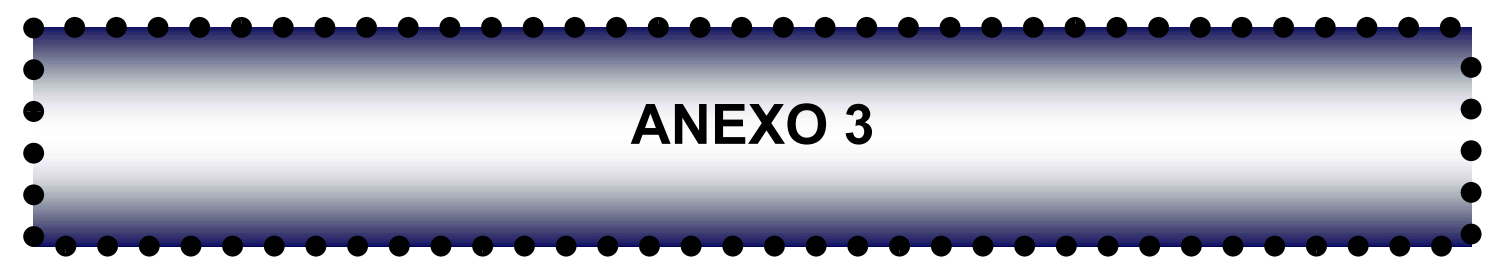


UBERLÂNDIA

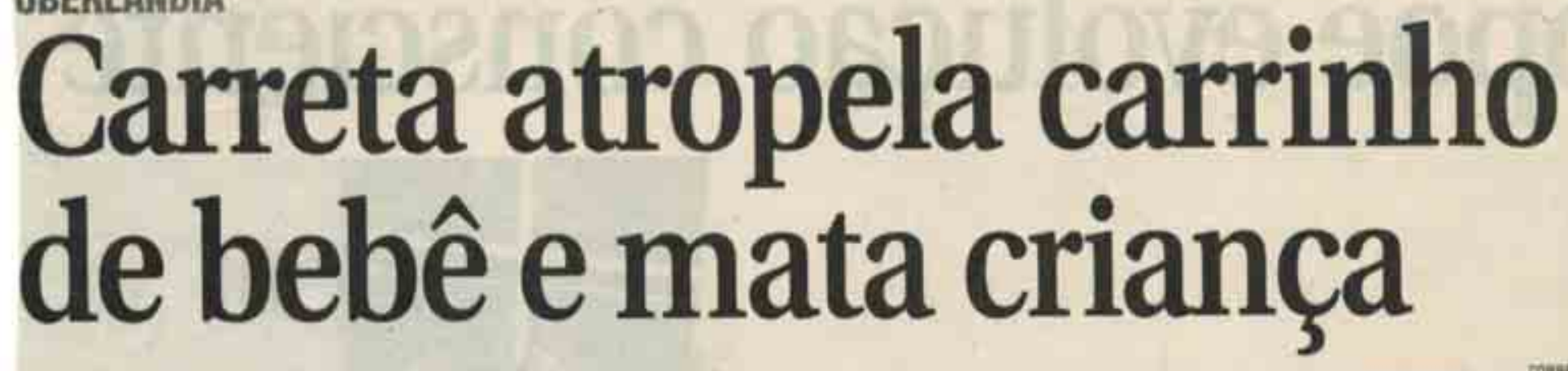

Mãe esperava sinal de semáforo abrir para passar com as filhas de 2 e 5 anos

PEDRO POP6
Editor

Um acidente envolvendo uma carreta, ocorrido ontem, em Uberlândia, porvolta das 11 h 30 , matou uma criança de 2 anos e deixou uma outra de 5 anos gravemente ferida. 0 desastre aconteceu no cruzamento das avenidas Antonio Thomaz Ferreira de Resende com Comendador Alexandrino Garcia, no acesso para o Distrito Industrial.

As vitimas estavam em um carrinho de bebê, conduzido pelamãe,Sonia Maria Rodrigues Santos, 22 anos. A mulher estava no passeio, perto do semáforo, no lado direito da av. Comendador Alexandrino Garcia, aguardando para passar, quando a carreta, ao fazer a conversāo à direita, atingiu o carrinho, arrastando-o para debaixo das rodas.

Caroline Vasconcelos Rodrigues Santos morreu na hora, atingida pelas ferragens. A irmă, G.V.R.S., caiu ao solo, esó nāo morreu porque ela foi atírada para fora do carrinho e a mâe conseguiu arrastá-la um pouco, a tempo de evitar o esmagamento. Mesmo assim, ela sofreu traumatismo cranioencefálicoe politraumatismo. A mãe

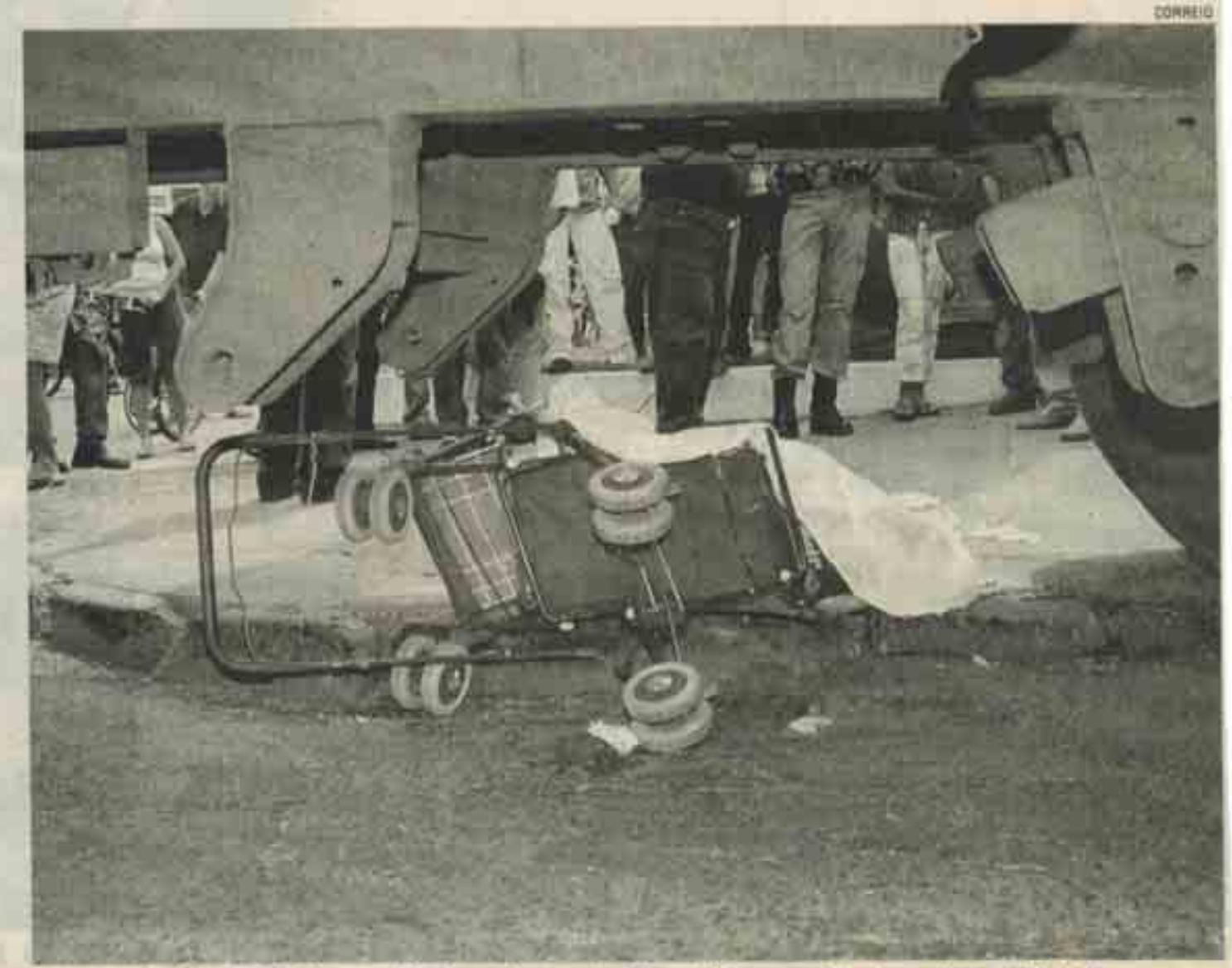

CARRIMHO de bebê ficou debaixo do caminhẫo até ser retirado pelos policiais

conseguiu sair iless.

Sonia tinha saído de casa, na rua Pedro Quirino da Sil. va, no bairto Marta Helena, próximo ao local, poucotempo antes. Desesperada, ela năo conseguiu explicar seu destino. Umfrentista, que trabalhava no posto de combustivel em frente à esquina, foi providencial. Ao ver a cena, ele correu em direção à cabine e gritou alertando o motorista.

O motorista Antônio Gomes Filho, 52 anos, emprega- do de uma granja, dirigia o caminhåo tipo gaiola, placas KBE-7084, de Monte Álegre, usado para transportar porcos. A carreta estavavazia. Ele contou ao cabo Carlos e ao soldado Madureira, que chegaram minutos depois, que nảo viua mãe com as fillhas. 0 frentista disse que ele năo o ouviu.

Principal testemunha, o frentista Joăo Pereira Vieira, 48 anos, contou que o motorista só percebeu que a carre. ta passou por cima da criança quando outras pessoas que estavam no posto também gritaram. Ao descer do caminhăo, Gomes Fitho teria se sentado no passeio em frente ao posto e chorado copiosamente. Ele foi detido pela policia.

O pai das crianças, Clayton de Vasconcelos Santos, chegou ao local as $12 \mathrm{~h} 10$, abraçou-se à mulher e juntos choraram muito. Ao perceber a presença de repórteres, elese afastou, demonstrando muita revolta. 